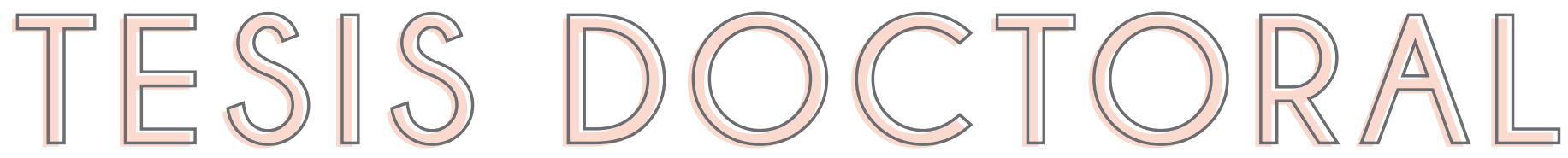

\section{“ESTRATEGIAS BIOLÓGICAS DESTINADAS A COMBATIR}

Escherichia coli ENTEROHEMORRÁGICA EN CARNE Y PRODUCTOS CÁRNICOS.

ESTUDIOS BIOQUÍMICOS Y TECNOLÓGICOS"

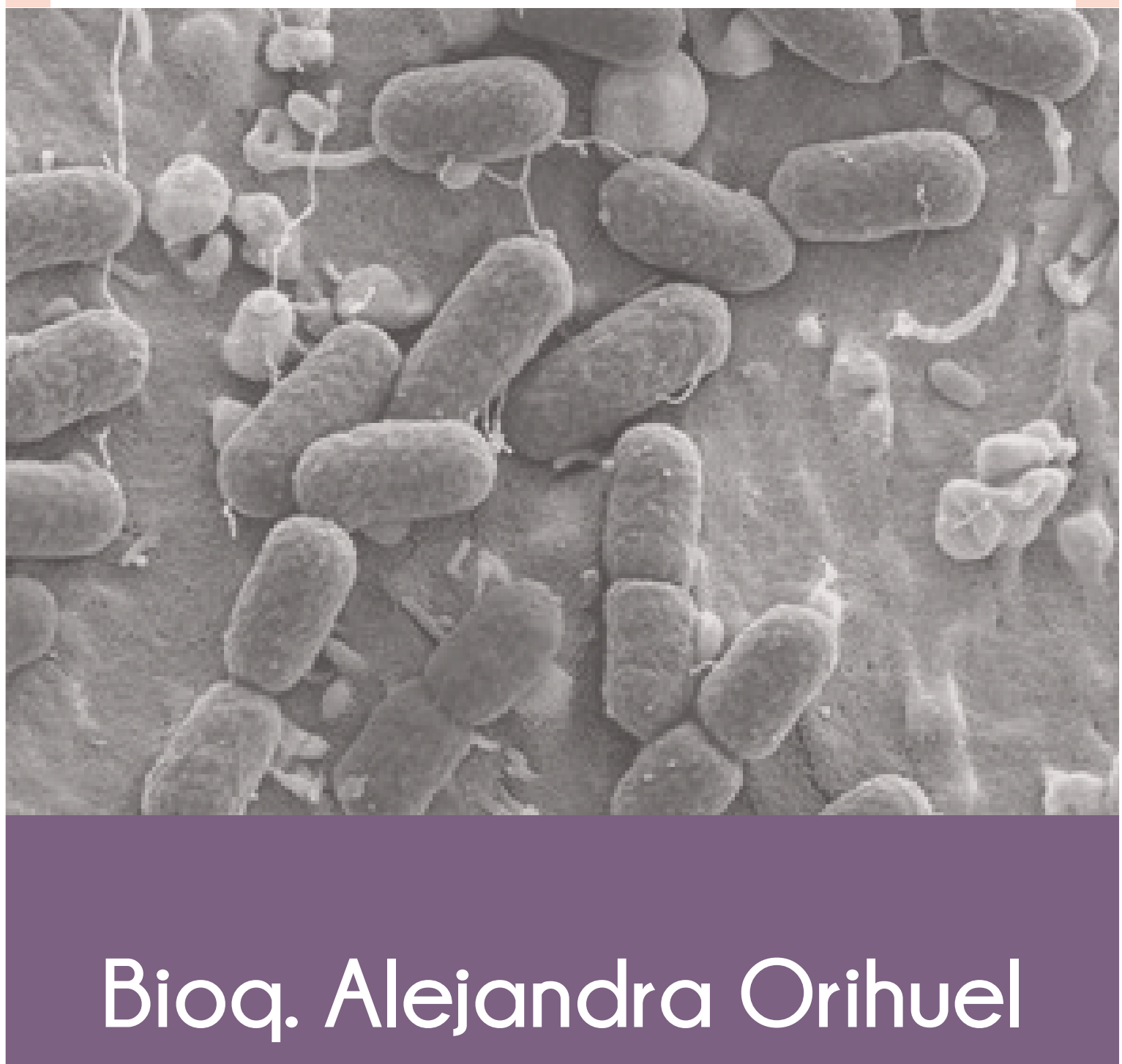

2018) 


\section{UNIVERSIDAD NACIONAL DE TUCUMÁN \\ Facultad de Bioquímica, Química y Farmacia}

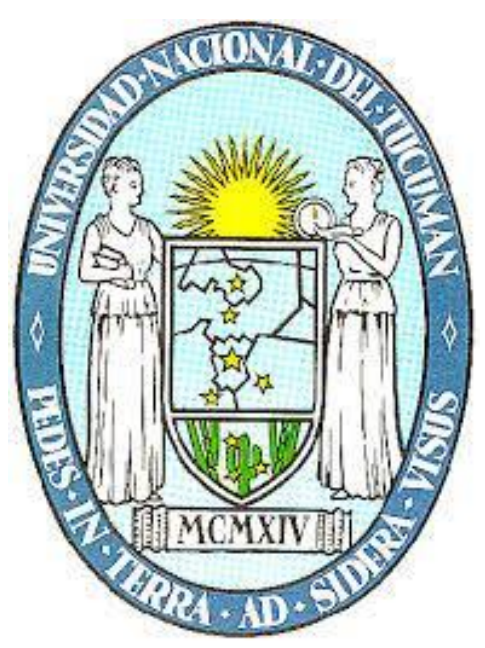

"Estrategias biológicas destinadas a combatir Escherichia coli enterohemorrágica en carne y productos cárnicos. Estudios bioquímicos y tecnológicos"

Bioq. Alejandra Orihuel

Año 2018 


\section{AUTORIDADES}

HONORABLE CONSEJO DIRECTIVO

Mag. Adriana Correa Zeballos

Dr. Manuel Javier Aybar

Dra. Viviana Andrea Rapisarda

Bioq. Esp. Ana Verónica Oldano

Dra. Ana Lucrecia Iruzubieta Villagra

Dra. María Antonieta Cordillo

Lic. Rodrigo Hernán Tomas Grau

Sr. Mario Rodríguez

Sr. Joaquín Hernán Vargas

Srta. Elizabeth Abigail Cutiérrez

Srta. Karen Nahir Ríos

\section{DECANO}

Dr. Edgardo Hugo Cutin

\section{VICE-DECANA}

Dra. Inés del Carmen Ramos

SECRETARIA DE ASUNTOS ACADÉMICOS

Dra. Marta Elena Cecilia

JEFA DEL DEPARTAMENTO DE POSGRADO

Lic. Marta Quinteros 


\title{
DEPARTAMENTO DE POSGRADO
}

\section{AUTORIDADES}

\author{
DIRECTOR \\ Dr. Sergio Enrique Pasteris
}

\section{CONSEJO TITULAR}

Dra. Inés del Carmen Ramos

Dra. María Carolina Navarro

Dra. María Cristina Gaudioso

Dra. Paula Andrea Vincent

Dra. María Cristina Rubio

\section{CONSEJO SUPLENTE}

Dra. María Graciela Benzal

Dra. Clara del Valle Silvia de Ruíz

Dra. María Inés Nieva Moreno

Dra. Claudia Alejandra Crespo

Dra. María Angélica Véliz

\section{REPRESENTANTE DE POSGRADO ANTE LA SECRETARÍA DE POSGRADO DE LA UNT \\ Dr. Sergio Enrique Pasteris (Titular) \\ Dra. María Cristina Caudioso de Allori (Suplente)}




\title{
TRABAJO DE POSGRADO PARA LA OBTENCIÓN DEL GRADO ACADÉMICO SUPERIOR DE DOCTORA EN CIENCIAS BIOLÓGICAS
}

\section{CARRERA DE DOCTORADO EN CIENCIAS BIOLÓGICAS}

\author{
Acreditado y Categorizado A ante la \\ Comisión Nacional de Acreditación Universitaria (CONEAU) \\ Resolución N: 615/07 \\ Acreditado y Categorizado A ante la \\ Comisión Nacional de Acreditación Universitaria (CONEAU) \\ Resolución n: Resolución 750 - CONEAU-13
}

\section{Director}

Dr. Atilio Pedro Castagnaro

\author{
Vice-Directora \\ Dra. Lucia Claps
}

Comité Académico

Dr. Alfredo Grau

Dr. Raúl Pedraza

Dra. Silvina Fadda 
TRABAJO DE POSGRADO TITULADO:

ESTRATEGIAS BIOLÓGICAS DESTINADAS A COMBATIR Escherichia coli ENTEROHEMORRÁGICA EN CARNE Y PRODUCTOS CÁRNICOS. ESTUDIOS BIOQUÍMICOS Y TECNOLÓGICOS

\section{TESISTA}

Bioq. Alejandra Orihuel

DIRECTOR

Dra. Silvina C. Fadda

\section{CO-DIRECTOR}

Dra. Lucila Saavedra

COMISIÓN DE SUPERVISIÓN

Dra. Cabriela Zárate

Dra. Mónica Delgado 
Esta Tesis Doctoral se desarrolló en el Centro de Referencia para Lactobacilos (CERELA), dependiente de CONICET, de la Fundación Miguel Lillo y de la Fundación para la Educación, la Ciencia y la Cultura (FECIC).

\section{E R E L A

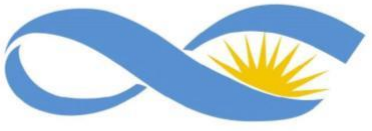 \\ CON I CET}

Este trabajo de Tesis Doctoral se financió a través de becas y subsidios otorgados por las siguientes instituciones: el Consejo Nacional de Investigaciones Científicas y Técnicas (CONICET) y la Agencia Nacional de Promoción Científica y Tecnológica (ANPCYT).

Quisiera agradecer también a CONICET por haberme otorgado la beca que posibilitó la realización de este trabajo de tesis y destacar la importancia que tiene la inversión del Estado Argentino en Ciencia y Tecnología, la cual permite la formación altamente calificada de profesionales en nuestro país. 
Durante la realización de esta tesis doctoral fueron publicados los siguientes artículos en revistas científicas internacionales con referato:

- Alejandra Orihuel, Julieta Bonacina, María José Vildoza, Elena Bru, Graciela Vignolo, Lucila Saavedra, Silvina Fadda (2018). "Biocontrol of Listeria monocytogenes in a meat model using a combination of a bacteriocinogenic strain with curing additives". Food Research International. Doi: 2018.02 .043$.

- Alejandra Orihuel, Lucrecia Terán, Jenny Renaut, Graciela M. Vignolo, André M. De Almeida, María L. Saavedra and Silvina Fadda (2018). "Differential proteomic analysis of Lactic Acid Bacteria-Escherichia coli O157:H7 interaction and its contribution to bioprotection strategies in meat". Frontiers in Microbiology. Doi: 2018.01083.

- Alejandra Orihuel, Lucrecia Terán, Emilse Masias, Jenny Renaut, Carlos Minahk, André M. De Almeida, María Lucila Saavedra, Silvina Fadda. "Proteomic and physiological appraisal of the interaction of Escherichia coli 0 157:H7 with a bioprotective lactic acid bacterium in a meat environment". EN REDACCION

Y las siguientes presentaciones a congresos:

- 2015. Orihuel, Alejandra, Saavedra Lucila, Vignolo Graciela, Fadda Silvina. "Interacción entre bacterias lácticas bioprotectoras y Escherichia coli O 157:H7 durante el crecimiento como cultivos planctónicos en medio cárnico". XI Congreso Argentino de Microbiología General SAMICE. Ciudad de Córdoba. Modalidad póster.

- 2016. Orihuel, Alejandra, Saavedra Lucila, Fadda Silvina. "Proteomic analysis of the Enterococcus mundtii CRL 35-Escherichia coli O157:H7 interaction during its growth in meat medium". V Simposio Internacional de Bacterias Lácticas (SIBAL). Organizado por el Centro de Referencia de Lactobacilos (CERELA - CONICET). San Miguel de Tucumán, Tucumán, Argentina. Modalidad póster. 
- 2016. Bonacina Julieta, Orihuel Alejandra, Fadda Silvina and Saavedra Lucila. "Unraveling Enterococcus mundtii CRL35 behaviour in a chemically defined medium supplemented with meat proteins." V Simposio Internacional de Bacterias Lácticas (SIBAL). Organizado por el Centro de Referencia de Lactobacilos (CERELA - CONICET). San Miguel de Tucumán, Tucumán, Argentina. Modalidad póster.

- 2017. Orihuel Alejandra, Cisneros Lucía, Torres Carolina, Saavedra Lucila and Fadda Silvina. "Biochemical and molecular characterization of enterohemorrhagic Escherichia coli NCTC12900 as atoxigenic model of study in meat". Reunión conjunta de Sociedades de Biociencias. Buenos Aires, Argentina. Comunicación oral.

- 2018. Orihuel Alejandra, Baillo Ayelén Antonella, Saavedra María Lucila, Fadda Silvina Graciela. "Bacterias Lacticas bioprotectoras capaces de mitigar Escherichia coli O157:H7 en carne. Estudios in vitro e in situ". IAFP VI Simposio Latinoamericano de Inocuidad Alimentaria, III Simposio Argentino de Inocuidad Alimentaria. Buenos Aires, Argentina. Modalidad póster. Mención de honor otorgada por Publitec. 


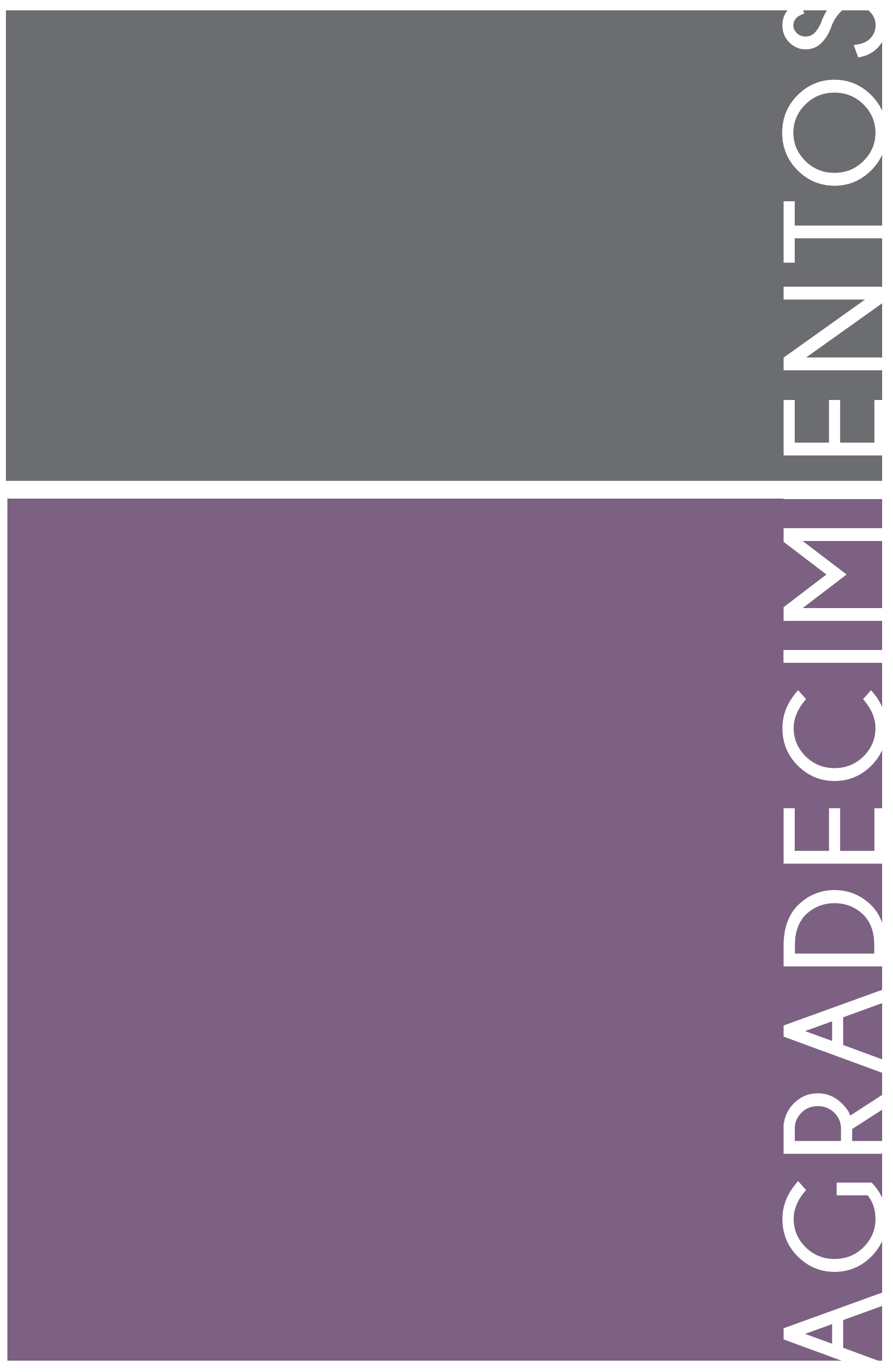


En primer lugar, siento una fuerte necesidad de agradecer a quién confió en mí, quien me motivó y caminó conmigo incondicionalmente durante estos 5 años, mi directora. Gracias Sil F., gracias, gracias...por creerme capaz, por enseñarme siempre con una sonrisa, por tu generosidad, por hacerme tan bien y darme claridad con cada charla. Gracias por tus conocimientos, tu dedicación, tu profesionalismo, pero sobre todo hoy quiero agradecerte por tu lado humano, por tu empatía y buena energía diaria. Cracias por hacerme sentir que fuimos siempre un equipo tirando hacia el mismo lado. Tu excelencia académica junto a la gran persona que sos fueron la combinación perfecta que me permitió, como te dije siempre, DISFRUTAR de este trabajo. Gracias, muchas gracias de corazón.

A mi codirectora, gracias por tus valiosos aportes Lulú S., por estar siempre presente cuando lo necesitamos, por tu compromiso, tu tiempo y generosidad. Gracias por tus consejos y sobre todo por tener siempre una sonrisa contagiosa para suavizar la rutina sin restar compromiso al trabajo. Gracias Lulú.

Al querido Dr. Raúl R. Raya, gracias por su interés genuino por el otro, por tener siempre una palabra de aliento, por su inagotable sabiduría y su capacidad única de transmitirla. Por tener para cada ocasión una anécdota para contar, a la cual todos escuchamos con una sonrisa y ansiosos de saber cómo termina. Gracias por robar sonrisas en cada pasillo de Cerela. Cracias por el café que ofrece a diario casi como un ritual de nuestros mediodías. Gracias Dr. por alegrar nuestros días de trabajo.

Cracias a todo el personal de Cerela que lleva a cabo sus funciones con una sonrisa y mucho cariño. Gracias Julito, Yoli, Mario, José Luis, Richard, Martita M., Mabeluchi, Pablito, Rocío, Sebas, Caro. A todos los becarios, que son el gran capital humano de la institución, en especial a los chicos del sum, con quién a diario compartimos el trabajo así como también los mates y charlas fundamentales para matizar el día.

A la Comisión de Supervisión, Mónica Delgado y Gabriela Zárate, por sus valiosos aportes en la escritura del manuscrito y por su acompañamiento durante el desarrollo de la tesis. 
A la Facultad de Bioquímica, Química y Farmacia que me brindó formación de excelencia para obtener este título y a la sociedad argentina, por ser quiénes anónimamente sostienen y permiten la actividad científica de nuestro país como herramienta esencial para trascender.

A mis primeros y por siempre amigos, Mati R. y Gabi S., por tantos momentos que quedaran grabados en mí. Gracias Mati por tantas risas, por entendernos sobrando las palabras. Gracias Gabi querido por tantos cafés que significaban una intensa y renovadora charla juntos. Gracias por acordarte siempre de mí. Nuestra amistad es de lo más valioso que estos años me regaló.

A una gran amiga y persona, Lucre T.. Gracias por este hermoso tiempo de trabajo compartido, hiciste grandes aportes a este trabajo de tesis, y me permitiste conocer la gran persona y excelente profesional que sos. Disfrute cada charla que tuvimos. Cracias Lucre querida.

A mi amiga, vecina, y gran compañera Romi L.. Las casualidades nos acercaron este último tiempo y gracias a ellas conocí la gran persona que sos. Disfrute de cada recreo de las 11 am, cada almuerzo, mates y charlas necesarias para tomar aliento y seguir. Gracias por tu amistad Romi.

A alguien muy especial en esta última etapa, gracias Anto R., por nuestras intensas conversaciones, por escucharnos, renegar, pero siempre al final concluir que tenemos un montón y esto recién empieza. Gracias por tu transparencia y generosidad, gracias Anto.

A mi gran amiga, gracias Ale Co. querida, gracias por cuidarme, por tu generosidad, por compartir conmigo esta última etapa de trabajo, por apoyarnos y hacerme sentir que juntas era más fácil. Gracias por preguntarme todos los días cómo estaba, porque sentía en esa pregunta tus ganas genuinas de saber si era un buen día para mí. Gracias amiga, te voy a extrañar.

Un gracias especial a personas con las que compartí mis primeros años de trabajo y dejaron hermosos recuerdos en mi: Juli Bonacina, gracias por tu generosidad y tus aportes a este trabajo. Vicky Terán y Mariana Pérez I. gracias por los momentos compartidos en aquel '128'. 
A quién incondicionalmente me apoya, me impulsa y me sostiene... gracias mamá, por vivir mis logros como si fueran tuyos y por tu inagotable generosidad. Cracias por cuidar de lo más preciado que tengo, mi bebé, con un amor único y regalarme la tranquilidad de trabajar sabiendo q ella está en manos de quién la ama tanto como yo. Eterno gracias para vos, mi mamá.

Gracias a mis amadas hermanas, Mari, Gabi y Virgi, porque me apoyaron siempre, y estuvieron presentes en cada paso, en cada logro. Gracias Virgi por tu ayuda diaria en el cuidado de Cande, ella y yo somos felices que así sea.

Finalmente...a ellos, mi vida entera, mi familia.... Luis y Cande...

Fue muy fácil este camino con un compañero como vos amor, fue muy fácil sintiéndote cerca, teniendo tu abrazo cuando llegaba a casa, teniendo tu mano cuando el cansancio me ganaba. Gracias por enseñarme a vivir todos los días. Te amo, te admiro y te quiero todos los días a mi lado. Cracias mi amor.

Y a ella, mi siempre bebé Cande, que me das vida todos los días. Gracias por enseñarme a optimizar cada minuto de mi tiempo, porque ya no hay minutos que sobren, son todos para vos que me esperas cada tarde para jugar y mimarte. Gracias por el efecto mágico de tus abrazos que me renuevan completamente como la mejor medicina ante cualquier mal día. Cracias por llegar a mi vida y hacerme una mejor persona. 


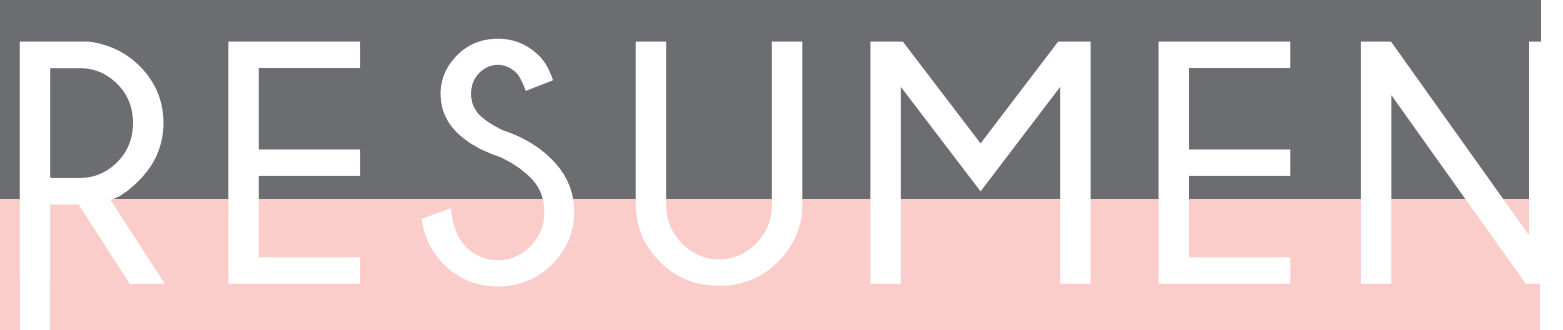


Escherichia coli enterohemorragica (ECEH) constituye una gran preocupación para la sostenibilidad de la industria de la carne y una grave amenaza para la salud pública a nivel mundial. La infección humana por ECEH ocurre a través de la ingestión de alimentos contaminados, principalmente carnes picadas. Además, el 5 10\% de los pacientes infectados con ECEH (especialmente niños y adolescentes) desarrollan una grave patología, el Síndrome Urémico Hemolítico. Argentina es, a nivel mundial, el país con mayor incidencia de esta enfermedad.

En este contexto urge la necesidad de proporcionar a la industria de la carne soluciones sustentables para limitar y prevenir riesgos. Las bacterias lácticas $(B L)$, presentes de forma natural en la carne, son de gran interés tecnológico debido a la capacidad de ciertas cepas para inhibir microorganismos patógenos y/o deteriorantes en alimentos. Además, las BL generalmente se consideran seguras (CRAS), de manera que su uso como bioprotectores en alimentos constituye una estrategia real. Sin embargo, hasta el momento no se dispone en el mercado de un cultivo láctico capaz de inhibir ECEH en carne. En este contexto, el objetivo de este trabajo fue determinar el potencial de cepas BL para inhibir a ECEH en carne y estudiar las bases moleculares subyacentes a la interacción entre BL-ECEH. Las cepas de BL estudiadas (Lactobacillus curvatus CRL705, Lactobacillus plantarum CRL681 y Enterococcus mundtii CRL35) fueron preseleccionadas por sus óptimas características bioquímicas y tecnológicas. Como patógeno modelo se utilizó la cepa atoxigénica E. coli O157:H7 NCTC 12900. Cada cepa de BL fue cocultivada con ECEH en un medio experimental cárnico. Ent. mundtii CRL35 resultó seleccionada como candidato por su significativa capacidad anti ECEH. Este efecto demostró ser independiente de la acción de bacteriocina, del ácido $u$ otro agente soluble producido por Ent. mundtii, sugiriendo la interacción célula-célula como uno de los mecanismos implicados en la inhibición. Mediante un enfoque proteómico comparativo se estudió las bases moleculares subyacentes a esta interacción bacteriana, pudiéndose correlacionar con éxito el perfil de proteínas sobreexpresadas con la fisiología de Ent. mundtii y una ventaja competitiva de la BL sobre el patógeno. Al estudiar el fenómeno de adhesión/colonización del alimento por ambos microorganismos, se observó una ventaja competitiva de Ent. mundtii con respecto a E. coli, en la unión a proteínas claves de la matriz extracelular cárnica. Finalmente, se diseñó un sistema experimental constituido por carne molida con el objetivo de evaluar la acción bioprotectora de Ent. mundtii in situ. Se observó un efecto bacteriostático de la BL sobre ECEH, aunque de menor magnitud que aquél 
observado in vitro. Este resultado sugiere la necesidad de ensayos tecnológicos adicionales para optimizar la acción bioprotectora de esta cepa en un escenario real.

Este trabajo de tesis Doctoral, es pionero en los estudios de interacción entre una BL y un patógeno como ECEH, aplicando un enfoque multidisciplinario. Los resultados obtenidos contribuyen directamente a la tecnología de alimentos cárnicos, proponiéndose por primera vez un cultivo láctico contra ECEH, un patógeno alimentario que demanda soluciones urgentes en nuestro país. 
Enterohemorrhagic Escherichia coli (EHEC) is a major concern for the sustainability of the meat industry and a serious threat to public health worldwide. Human EHEC outbreaks are linked to the consumption of contaminated food, mainly minced bovine meat. In addition, 5-10\% of patients infected with EHEC (especially children and adolescents) develop a serious pathology, the hemolytic uremic syndrome. Argentina is the country with the highest incidence of this disease.

In this context, the need to provide the meat industry with sustainable solutions to limit and prevent risks is urgent. Lactic Acid Bacteria (LAB), naturally present in meat, are of high technological interest due to the ability of certain strains to inhibit pathogenic and/or spoilage microorganisms in foodstuffs. In addition, LABs are generally considered safe (CRAS), so their use as bioprotective cultures in food constitutes a real strategy. However, so far there is no available in the market a LAB culture active towards EHEC in meat. In this context, the objective of this work was to determine the potential of LAB strains to inhibit EHEC in meat and to study the molecular bases underlying the interaction between LAB-EHEC. The studied LAB strains (Lactobacillus curvatus CRL705, Lactobacillus plantarum CRL681 and Enterococcus mundtii CRL35) were preselected according to their optimal biochemical and technological characteristics. As pathogen model, the atoxigenic strain E. coli O 157: H7 NCTC 12900 was used. Each LAB strain was cocultivated with EHEC in an experimental meat medium. Ent. mundtii CRL35 was selected as a candidate for its significant anti-EHEC capacity. This effect proved to be independent of the action of antimicrobial (bacteriocin, acid, etc) or other soluble compounds produced by Ent. mundtii, suggesting cell-cell interaction as one of the mechanisms involved in inhibition. The molecular bases underlying this bacterial interaction was studied by means of a comparative proteomic approach, being able to correlate with success, the profile of overexpressed proteins with the physiology of Ent. mundtii as well as a competitive advantage of the LAB over the pathogen. When studying the phenomenon of food adhesion/colonization by both microorganisms, by assaying the binding to the key proteins of the extracellular meat matrix, a competitive advantage of Ent. mundtii was also observed. Finally, an experimental system consisting of ground beef was designed with the aim of evaluating in situ the bioprotective action of Ent. mundtii. A bacteriostatic effect of LAB on EHEC was observed, although of lesser magnitude than that observed in vitro studies. This result suggests that additional experiments are required to optimize the bioprotective action of this strain in meat under real technological conditions. 
This work of doctoral thesis is the first research dealing in the interaction between a LAB and EHEC by applying a multidisciplinary approach. The obtained results will contribute directly to the meat technology and, for the first time, a LAB culture active against EHEC, a food pathogen that demands urgent solutions in our country is proposed. 

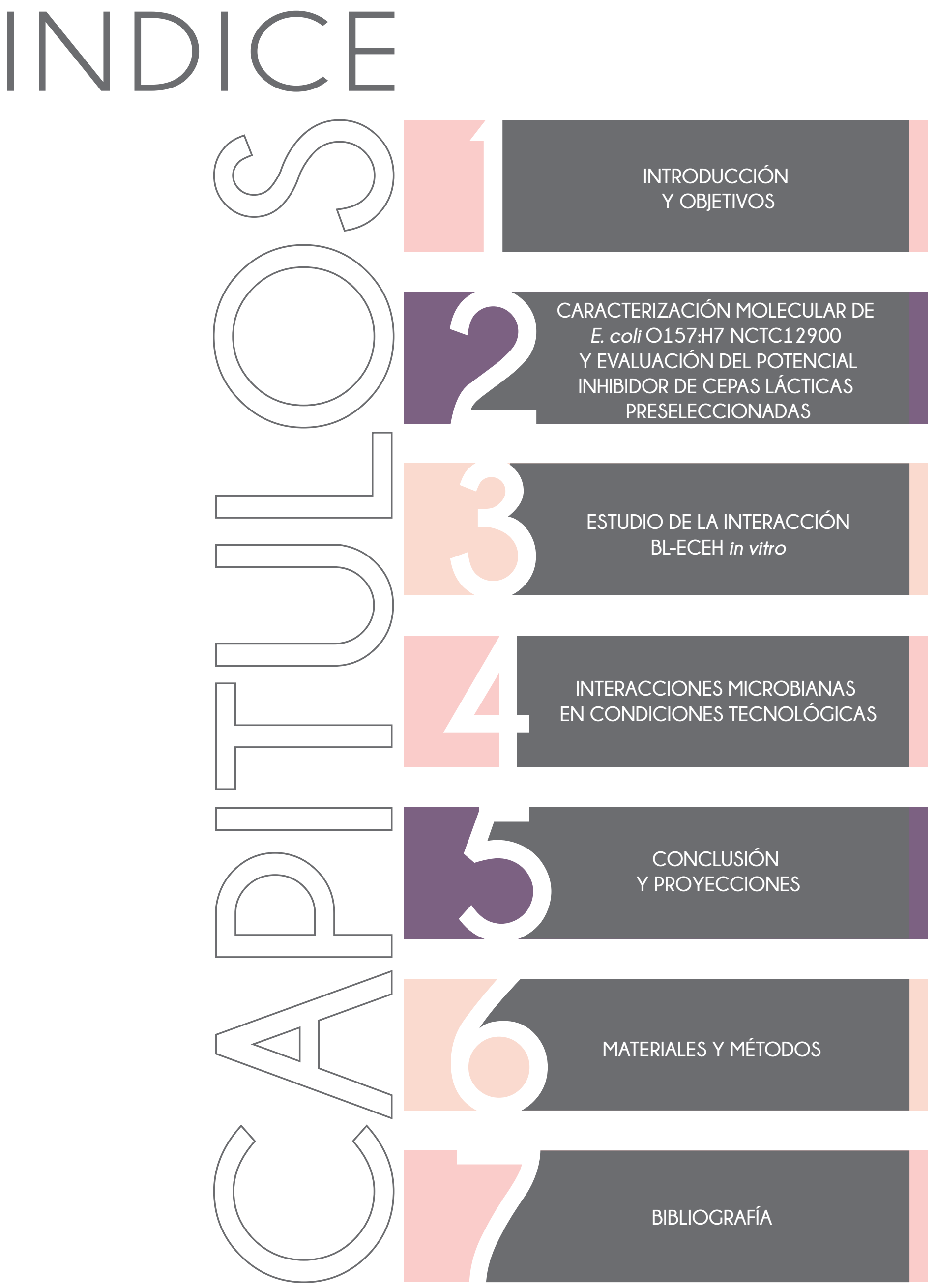


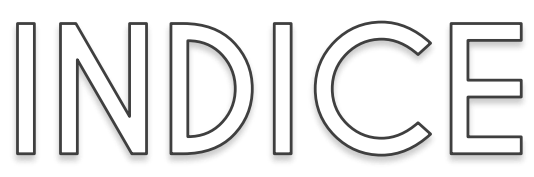

CAPÍTULO 1 - INTRODUCCIÓN Y OBJETIVOS ……………………………………….... 10

Introducción general ..................................................................................................... 11

Problemática y relevancia del estudio....................................................................32

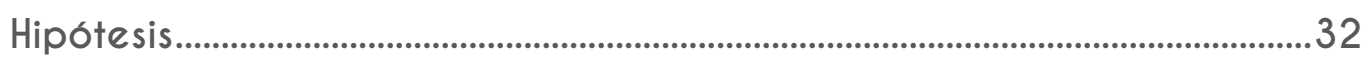

Objetivo general ........................................................................................................3

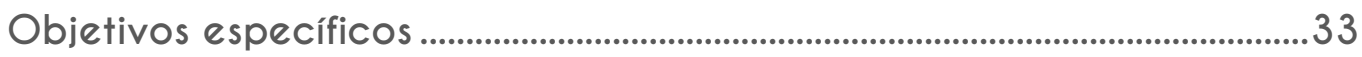

CAPÍTULO 2 - CARACTERIZACIÓN MOLECULAR DE E. coli O 157:H7

NCTC 12900 Y EVALUACIÓN DEL POTENCIAL INHIBIDOR DE CEPAS LÁCTICAS PRESELECCIONADAS

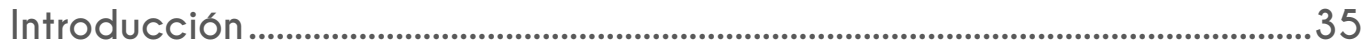

Caracterización de factores de virulencia de la cepa modelo E. coli O 157:H7 NCTC 12900 mediante PCR .....................................................................37

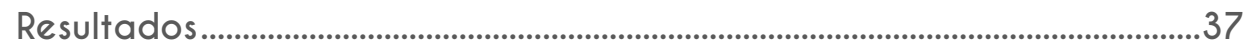

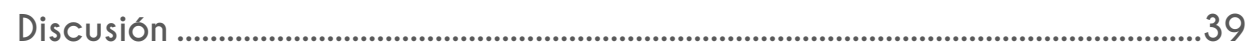

Ensayos de inhibición en placa.......................................................................... 41

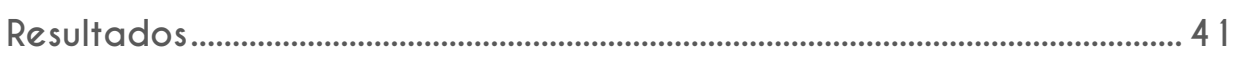

Discusion .................................................................................................................................. 42

Desempeño de BL y ECEH en ambientes cárnicos............................................ 44

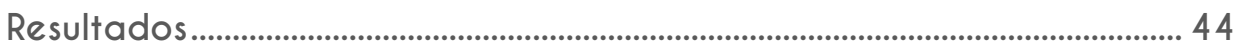

Discusion .......................................................................................................................... 47

Anexo Capítulo 2....................................................................................................49

CAPITULO 3 - ESTUDIO DE LA INTERACCIÓN BL-ECEH in vitro....................................53

Introducción .....................................................................................................................54

Estudios proteómicos de la interacción BL-ECEH: análisis de expresión diferencial......................................................................................................................56

Resultados ...................................................................................................................56

Discusion ........................................................................................................................ 57

A. Análisis proteómico para Ent. mundtii CRL35 durante su crecimiento en SCM ..............................................................................................59

Resultados.......................................................................................................................59

Discusión ..........................................................................................................................68

B. Análisis proteómico para ECEH..............................................................82 
Estudios de adhesión a proteínas de la matriz extracelular cárnica (MEC)

Resultados 107

Discusión 109

Efecto de Ent. mundtii CRL35 sobre la inducción del fago W933.......... 110

Resultados. 110

Discusión

Evaluación de la actividad antilisteria de Ent. mundtii CRL35 durante el cocultivo con ECEH en ambiente cárnico

Resultados 114

Discusión

\section{CAPITULO 4 - INTERACCIONES MICROBIANAS EN CONDICIONES} TECNOLÓGICAS

Introducción

Desempeño de Ent. mundtii y ECEH en carne molida: estudios fisiológicos

Resultados 119

Discusión

CAPÍTULO 5 - CONCLUSIÓN Y PROYECCIONES

Conclusión.

Proyecciones.

CAPITULO 6 - MATERIALES Y MÉTODOS.

Conservación de cepas.

Propagación

Medios de cultivo

CARACTERIZACIÓN MOLECULAR DE E. coli O 157:H7 NCTC12900 Y EVALUACIÓN DEL POTENCIAL INHIBIDOR DE CEPAS LÁCTICAS PRESELECCIONADAS

Caracterización de factores de virulencia de la cepa modelo $E$. coli

O 157:H7 NCTC 12900 mediante PCR

Selección de cepa BL con capacidad inhibitoria sobre ECEH.

ESTUDIO DE LA INTERACCIÓN BL-ECEH in vitro.

Análisis Funcional de Interacción de Proteínas sobreexpresadas. 
Ensayos de unión a Matriz Extracelular (MEC)

Evaluación del efecto inductor de Ent. mundtii CRL35 sobre el fago ய933

Influencia del cocultivo con ECEH en la producción de bacteriocina por Ent. mundtii CRL35: titulación de enterocina CRL35............................154

INTERACCIONES MICROBIANAS EN CONDICIONES TECNOLÓGICAS .... 156

Procesado y obtención de carne molida ........................................................ 156

Estudios fisiológicos en carne molida............................................................ 157

CAPÍTULO 7 - BIBLIOCRAFÍA .......................................................................................... 158 


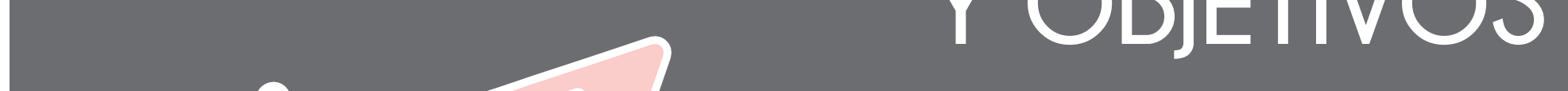

INTRODUCCIÓN Y OBJETIVOS
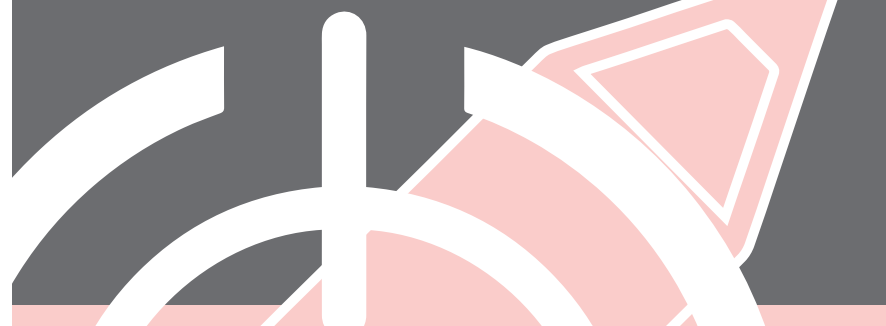


\section{CAPÍTULO 1 INTRODUCCIÓN Y OBJETIVOS}

\section{Introducción general}

\section{Enfermedades Transmitidas por Alimentos, un desafío del siglo XXI}

En el siglo XXI, las enfermedades transmitidas por alimentos (ETA), lejos de erradicarse, siguen constituyendo una gran preocupación para la salud pública en nuestro país y el mundo. Las ETA se definen como un conjunto de sintomas y signos clásicos originados por el consumo de productos alimenticios $e$ ingredientes, especias, bebidas y agua, que contienen agentes patógenos o sustancias tóxicas en cantidades tales que afectan la salud humana en forma aguda o crónica. En la actualidad se reconocen más de 250 ETA y las mismas se clasifican según el agente etiológico en i) intoxicaciones alimentarias, cuando son causadas por la ingestión de alimentos que contienen toxinas microbianas preformadas, productos químicos u otras sustancias abióticas, y en ii) infecciones alimentarias, cuando derivan del consumo de alimentos contaminados con agentes patógenos (parásitos, hongos, bacterias y/o virus). Según la Organización Mundial de la Salud (OMS), las ETA, constituyen uno de los problemas de salud más relevantes tanto en países desarrollados como en vías de desarrollo (Durruthy y col., 2018), siendo las más frecuentes aquellas ocasionadas por contaminación biológica. En los últimos años se registraron brotes ocasionados por patógenos emergentes y re-emergentes que pusieron de manifiesto la fragilidad de los programas de protección de alimentos para prevenir y controlar las ETA. Esto no solo significó un mayor riesgo para la población sino también un perjuicio para el comercio nacional e internacional de alimentos.

Los agentes causales más frecuentes son de origen bacteriano, entre ellos los géneros que pertenecen a la familia de las enterobacterias como Salmonella spp., Shigella spp., Yersinia spp. y Escherichia coli (E. coli), así como a especies Gram positivas como Staphylococcus aureus, Bacillus cereus, Listeria monocytogenes, Clostridium perfringens, Clostridium botulinum, entre otros (Rojas-Herrera y ConzálezFlores, 2006). 
La aparición de estas enfermedades fue en incremento en los últimos años debido a factores como la modernización, la comercialización y la globalización de la industria alimentaria así también como a cambios demográficos y de hábitos alimenticios.

Las ETA pueden ser causadas por la falta de seguridad en cualquier etapa de la cadena productiva, por lo que resulta imprescindible implementar prácticas y sistemas que aseguren la producción de alimentos seguros en toda la cadena alimentaria, es decir, "desde el campo hasta la mesa" (Cortés-Sánchez y SalgadoCruz, 2017).

\section{Escherichia coli enterohemorrágico: un patógeno emergente}

Los patógenos emergentes pueden definirse como agentes infecciosos que han aparecido recientemente en una población, o bien aquellos que ya son reconocidos pero cuya incidencia y/o rango geográfico se encuentran en rápido aumento, o bien tienen la probabilidad de aumentar en el futuro (Schlundt y col., 2004).

Entre los patógenos bacterianos considerados emergentes se destaca Escherichia coli productor de la toxina Shiga (STEC). STEC fue descrito por primera vez por Konowalchuk y col. en 1977, quien informó su capacidad de producir una toxina denominada Verotoxina, debido al efecto citotóxico en células Vero. Pocos años después se aislaron cepas de E. coli que producian un efecto citotóxico en células HeLa, el cual podía ser neutralizado por un antisuero anti-toxina Shiga de Shigella dysenteriae tipo I (O'Brien y col., 1982), por lo cual se la llamó "toxina tipo Shiga" (Stx).

Dentro del patotipo STEC, el subgrupo enterohemorrágico de E. coli (ECEH) se caracteriza por poseer factores de virulencia adicionales, y cuenta con más de 150 serotipos diferentes. Una característica fundamental que se encuentra en las cepas de ECEH, pero que no es exclusiva de estos organismos, es la capacidad de causar lesiones de adherencia/borrado (A/E del inglés "Attachment and Effacement") en el epitelio intestinal humano (Branchu y col., 2014). Algunos de los genes cuyos productos están involucrados en la producción de las lesiones de AVE se pueden utilizar, junto con la presencia de verocitotoxina, para identificar a ECEH. La clasificación en serotipos, mediante antígenos $\bigcirc$ (lipopolisacáridos somáticos), $H$ 
(flagelares) y K (capsulares), no es suficiente para la identificación de ECEH; también deben estar presentes factores de virulencia característicos de dichos organismos.

E. coli O157:H7 constituye el serotipo más frecuente, y por lo tanto el más estudiado, dentro de ECEH. Los miembros de otros serotipos pueden ser más heterogéneos, es decir, diferentes organismos pueden llevar distintos grupos de factores de virulencia. Sin embargo las cepas de E. coli O157:H7 son relativamente homogéneas, y cuentan con factores de virulencia bien caracterizados que pueden resumirse en tres grandes grupos de la siguiente manera (Figura 1.1):

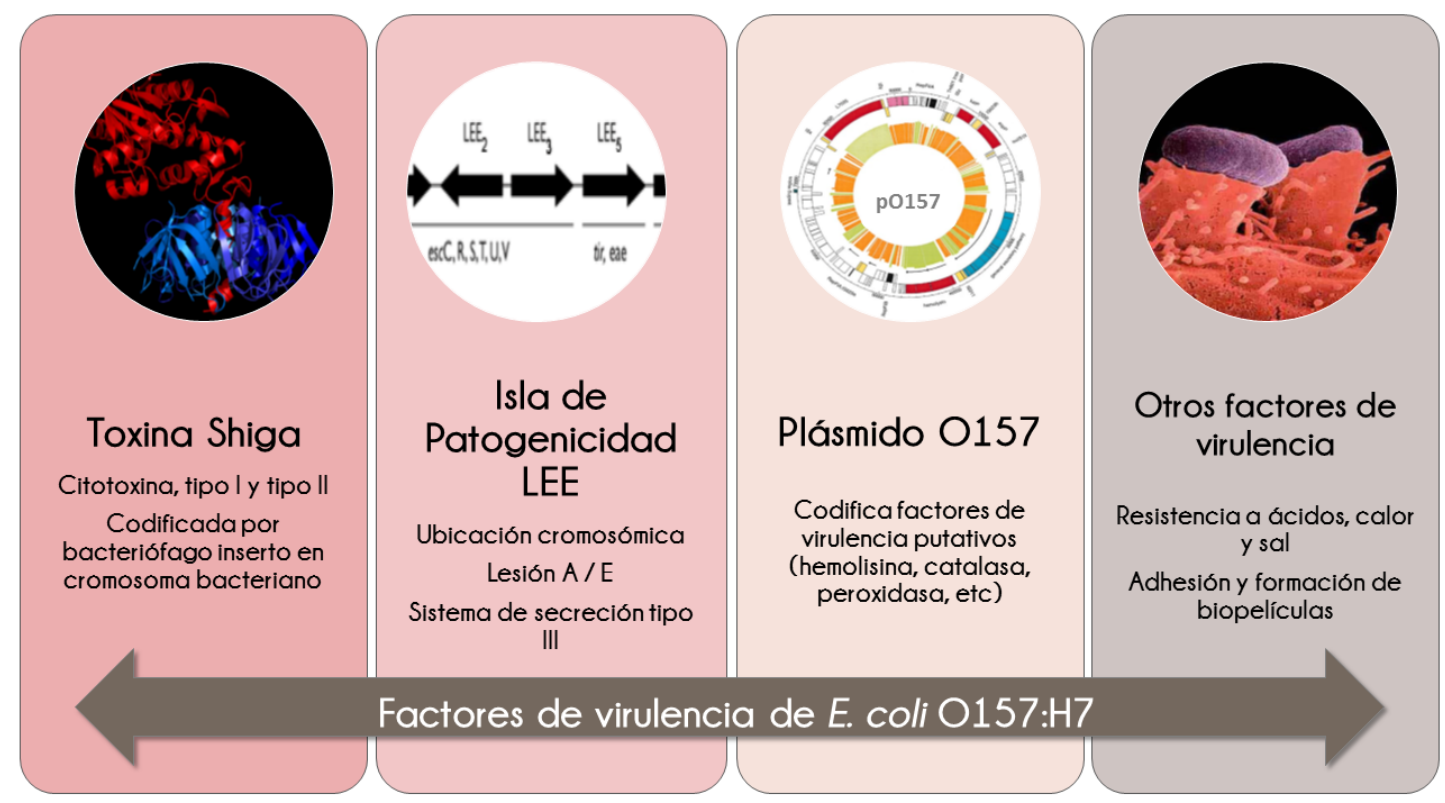

Figura 1.1. Clasificación de los principales factores de virulencia de E. coli O57:H7.

- $\quad$ Toxina Shiga (Stx): Stx fue descrita por primera vez en Shigella dysenteriae serotipo I por Kiyoshi Shiga y fue descubierta más tarde en ECEH (Sperandio y Pacheco, 2012), constituye una potente citotoxina capaz de inhibir la síntesis proteica e inducir apoptosis. Stx está constituida por una subunidad A enzimáticamente activa (A I) unida no covalentemente al pentámero de subunidades $B$ de unión al receptor (B5) por lo que es una toxina AB5. La subunidad B5 se une al receptor específico globotriosylceramida (Gb3) en la superficie de células eucariotas. Gb3 es expresado por las células de Paneth en la mucosa intestinal y por las células epiteliales renales (Tarr y col., 2005). Stx ingresa a la circulación sistémica a través de la absorción por el epitelio, permitiendo así su acceso a los riñones. El daño del epitelio gastrointestinal causado por ECEH probablemente ayuda en la absorción sistémica de Stx (Mukherjee y col., 2002). Tras la unión al receptor, Stx es endocitada por la célula eucariota (Römer y col., 2007) y alli, la subunidad A de Stx inhibe la síntesis de proteínas mediante la eliminación específica 
de un único residuo de adenina del ARNr 285 de la subunidad ribosomal 605 (Figura 1.2).

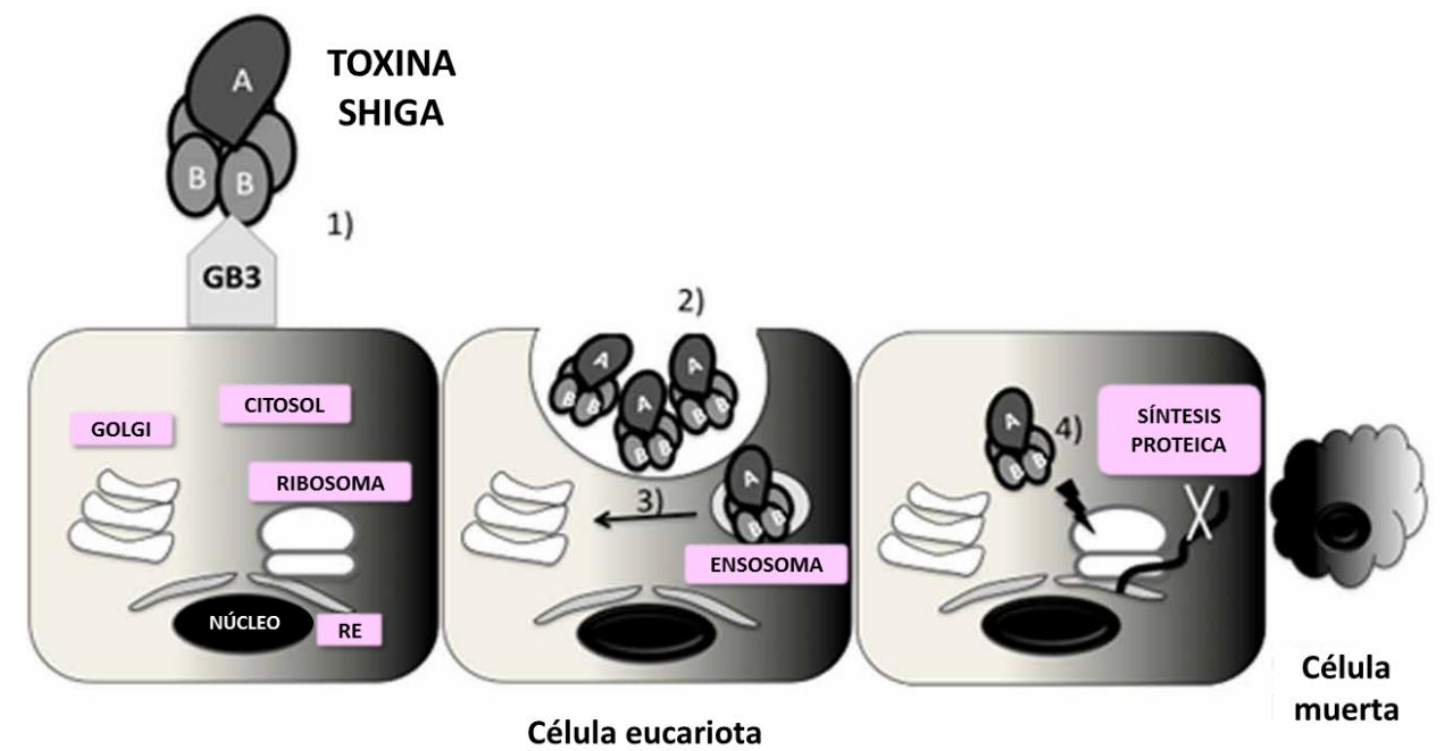

Adaptado de Pacheco y Sperandio, 2012.

Figura 1.2. Mecanismo de acción de la toxina Shiga. Stx está constituido por un pentámero de subunidades B unidas a una subunidad A catalítica. Las subunidades B se unen a globotriaosilceramida (Cb3) expresada por algunas células eucarióticas (1). Stx se internaliza por endocitosis (2) y mediante transporte retrógrado llega a la red trans-Colgi (3) y luego al retículo endoplasmático rugoso (RE) (4). En el RE, Stx encuentra su objetivo, el ribosoma, inactivándolo (4). Como consecuencia, Stx inhibe la síntesis de proteínas y causa la muerte celular por apoptosis.

La familia Stx tiene dos principales grupos: Stxl y Stx2. Aunque ambas comparten actividad enzimática y características estructurales, son inmunológicamente distintas, presentando solo el 55\% de similitud en sus secuencias de aminoácidos (Fraser y col., 2004). Los aislados virulentos de E. coli O 157: H7 pueden expresar solo Stx1, solo Stx2 o ambas toxinas, siendo Stx2 la de mayor toxicidad y asociado más comúnmente con infecciones humanas que las cepas Stx 1.

En E. coli O 157: H7 Stx está codificada por profagos (933W y 933J) (O'Brien y col., 1984) de la familia lambda que se encuentran integrados al cromosoma bacteriano en estado lisogénico (Johansen y col., 2001). La activación del ciclo lítico del fago lleva a la producción de Stx, la cual luego es liberada durante la lisis celular. El fago lambda permanece quiescente debido a la presencia de un represor que se encuentra inhibiendo la transcripción de los sitios promotores que regulan la expresión de los genes stxA y stxB. Para entrar en su ciclo lítico, el bacteriófago aprovecha la activación de la respuesta SOS (Graham, 1996) de la célula bacteriana. Al desencadenarse la respuesta SOS, se produce y activa RecA, una 
proteína que promueve el clivaje del represor llevando a la expresión de genes fágicos, incluyendo stxAB. Finalmente se produce la lisis bacteriana liberándose Stx al medio ambiente. Múltiples señales ambientales regulan la expresión de Stx, entre ellas podemos destacar estrés por temperatura, fase de crecimiento, antibióticos, especies reactivas de oxígeno (ROS), señales de quorum sensing, concentración de hierro, etc. La expresión, regulación y mecanismo de acción de esta toxina es objeto de profundos estudios, ya que el conocimiento de este sistema permitirá el desarrollo de nuevas estrategias para contrarrestar su efecto y prevenir enfermedades (Sperandio y Pacheco, 2012).

- Isla de patogenicidad LEE (Locus of Enterocyte Effacement): E. coli O 157: H7 coloniza la mucosa intestinal e induce la lesión histopatológica A/E característica. Dicha lesión se caracteriza por la adherencia bacteriana a la membrana de la célula epitelial y eliminación de las microvellosidades de los enterocitos. Las bacterias adheridas estimulan la polimerización de actina y su acumulación debajo de la membrana de la célula huésped, lo que da como resultado la formación de un pedestal de unión (Caprioli y col., 2005). Los estudios genéticos han demostrado que los genes responsables de las lesiones AVE se encuentran confinados a una región particular o isla de patogenicidad, designada como el locus del borramiento de enterocitos (LEE: Locus of Enterocyte Effacement). El LEE está compuesto de al menos 41 genes diferentes organizados en tres grupos principales; (i) un sistema de secreción tipo III (TTSS) que exporta moléculas efectoras; (ii) una proteína de adhesión llamada intimina y su receptor translocado, Tir, que se traslada a la membrana de la célula huésped mediante el TTSS; y (iii) varias proteínas efectoras secretadas mediante el TTSS, que son importantes en la modificación de la transducción de señales de la célula huésped durante la formación de lesiones AVE (Delahay y col., 200 I).

- Plasmido O157 (pO157): E. coli O157: H7 contiene un plásmido no conjugativo altamente conservado, denominado pO157. El pO157 muestra una estructura dinámica e incluye diferentes elementos genéticos móviles, como transposones, profagos, secuencias de inserción (IS) y partes de otros plásmidos. Esto indica que el actual plásmido p0157 se formó mediante la integración de fragmentos de especies de orígenes evolutivamente diferentes, y por lo tanto los factores de virulencia en los diferentes segmentos de pO157 pueden ser de distintos orígenes. Treinta y cinco proteínas codificadas por el plásmido están probablemente 
involucradas en la patogénesis de las infecciones por E. coli O 157: H7, de las cuales solo 19 genes se han caracterizado previamente, entre ellos los que codifican para una hemolisina ( $h l y A)$, una catalasa-peroxidasa (katP), un sistema de secreción tipo II (etp), una serina proteasa (espP), una adhesina putativa (toxB), una metaloproteasa de zinc (stcE) y un fragmento conservado de eae (ecf). Sin embargo, la importancia biológica de la pO157 en la patogénesis no se comprende aún completamente (Lim y col., 2010).

Síndrome Urémico Hemolítico: Argentina encabezando las estadísticas

El 5-10\% de los pacientes infectados con ECEH desarrollan síndrome urémico hemolítico (SUH). El SUH es una enfermedad de comienzo agudo con anemia hemolítica, trombocitopenia (bajo recuento de plaquetas) y daño renal que se presenta generalmente a continuación de un episodio de diarrea con o sin sangre, principalmente en lactantes y niños en la primera infancia (Fernández-Brando y col., $2011)$. Además, puede afectar otros órganos como sistema nervioso central, pulmones, páncreas, corazón, y conducir a la muerte debido a complicaciones neurológicas, intestinales, cardíacas o a infecciones intercurrentes (Repetto, 2005).

Argentina presenta la mayor tasa de incidencia mundial de SUH en niños menores a 5 años de edad, constituyendo un problema crítico para la salud pública nacional. El SUH es la principal causa pediátrica de insuficiencia renal aguda y la segunda de insuficiencia renal crónica, siendo además responsable del 20\% de los trasplantes de riñón en niños y adolescentes en Argentina (Eymann y col., 20 16).

El gráfico presentado en la Figura 1.3 fue confeccionado en base a datos del Sistema Nacional de Vigilancia de la Salud (SNVS C2-SIVILA-UCSUH). Como puede observarse, durante el período comprendido entre los años 2010-2017, se registraron entre 300 y 360 casos de SUH por año, siendo 326 los casos notificados durante el último año (2017) de los cuales el 40,5\% se presentó en niños de 2 a 4 años (Figura 1.3). 


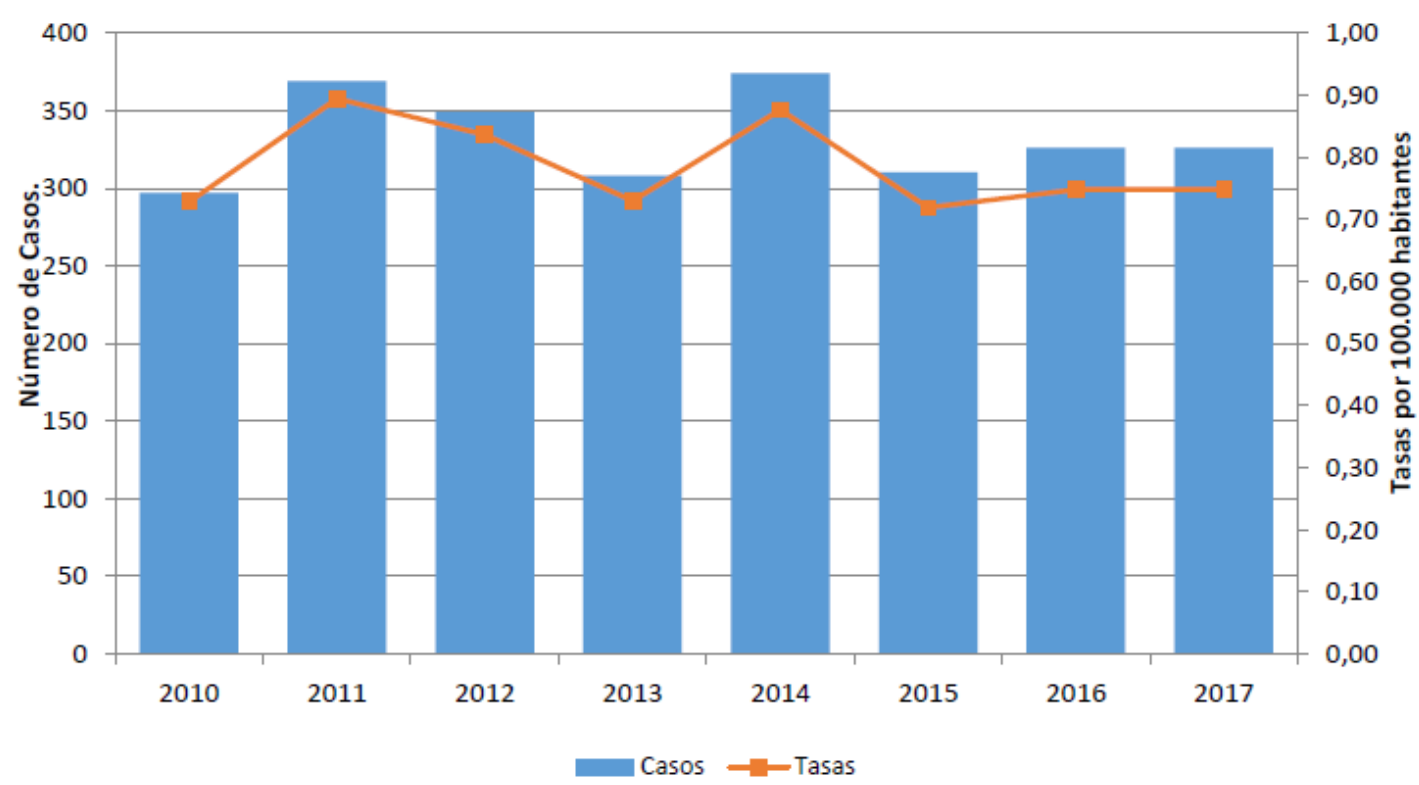

Fuente: Boletín Integrado de Vigilancia No 395- SE 032018.

Figura 1.3. Casos y tasas (por 100.000 habitantes) notificados de SUH en Argentina en el período $2010-2017$.

Las cepas de ECEH se encuentran altamente diseminadas en nuestro país, han sido aisladas en diferentes localidades. Estas cepas son capaces de sobrevivir, persistir a través del tiempo en diferentes nichos y diseminarse a distintos reservorios aumentando la probabilidad de transmisión a la población humana. El patógeno es de fácil transmisión por su baja dosis infectiva ( 10 a 100 bacterias por gramo de alimento) (Rivas y col., 2006b). Ocurre principalmente por vía fecal-oral, frecuentemente a través de la ingestión de agua o alimentos contaminados, contacto directo con personas o animales infectados u objetos (Carcía y col., 2010) (Figura 1.4). El reservorio natural más importante de ECEH incluye rumiantes y en particular el ganado bovino, con prevalencias muy variables pero que pueden alcanzar valores del 44\%. También se han reportado infecciones en otros animales domésticos como ovejas, cabras, cerdos, búfalos, perros y gatos. La mayoría de los animales son portadores asintomáticos de ECEH. Además, ECEH tiene la capacidad de replicarse y sobrevivir prolongadamente en nichos ambientales, como ser fuentes de agua, y se ha postulado que la diseminación entre animales podría ocurrir a través de la transmisión por vectores, como moscas u otros insectos (Carcía y col., 2010). Por otra parte, los individuos infectados resultan altamente contagiosos y la transmisión persona-persona podría tener un rol importante en la alta incidencia de SUH en nuestro país (Rivero y col., 2010).

La excreción de bacterias del serotipo $\mathrm{O}$ 157:H7 por el ganado bovino y la prevalencia de contaminación de los productos derivados ocurre mayoritariamente 
durante los meses cálidos, lo cual explicaría la mayor frecuencia de infección registrada durante esa época del año (Rivero y col., 2012).

Son numerosas las estrategias en estudio para combatir esta patología, muchas de ellas destinadas a bloquear la acción de Stx (Sperandio y Pacheco, 2012). Sin embargo, el único tratamiento disponible actualmente para los pacientes con SUH es de sostén a través del consumo de líquido y dieta blanda. El uso de drogas que inhiben la motilidad intestinal, o agentes anti-diarreicos que impiden la eliminación del patógeno están contraindicados así como también el tratamiento con antibióticos ya que su uso se ha asociado a la mayor probabilidad de desarrollo de SUH. Esto es debido a que aquellos antibióticos que dañan el DNA gatillan la respuesta SOS en ECEH y por lo tanto inducen la activación del ciclo lítico del fago codificador de la toxina Stx, generando por lo tanto mayor probabilidad de desarrollar SUH (Rivero y col., 2010; Fernández-Brando y col., 2011).

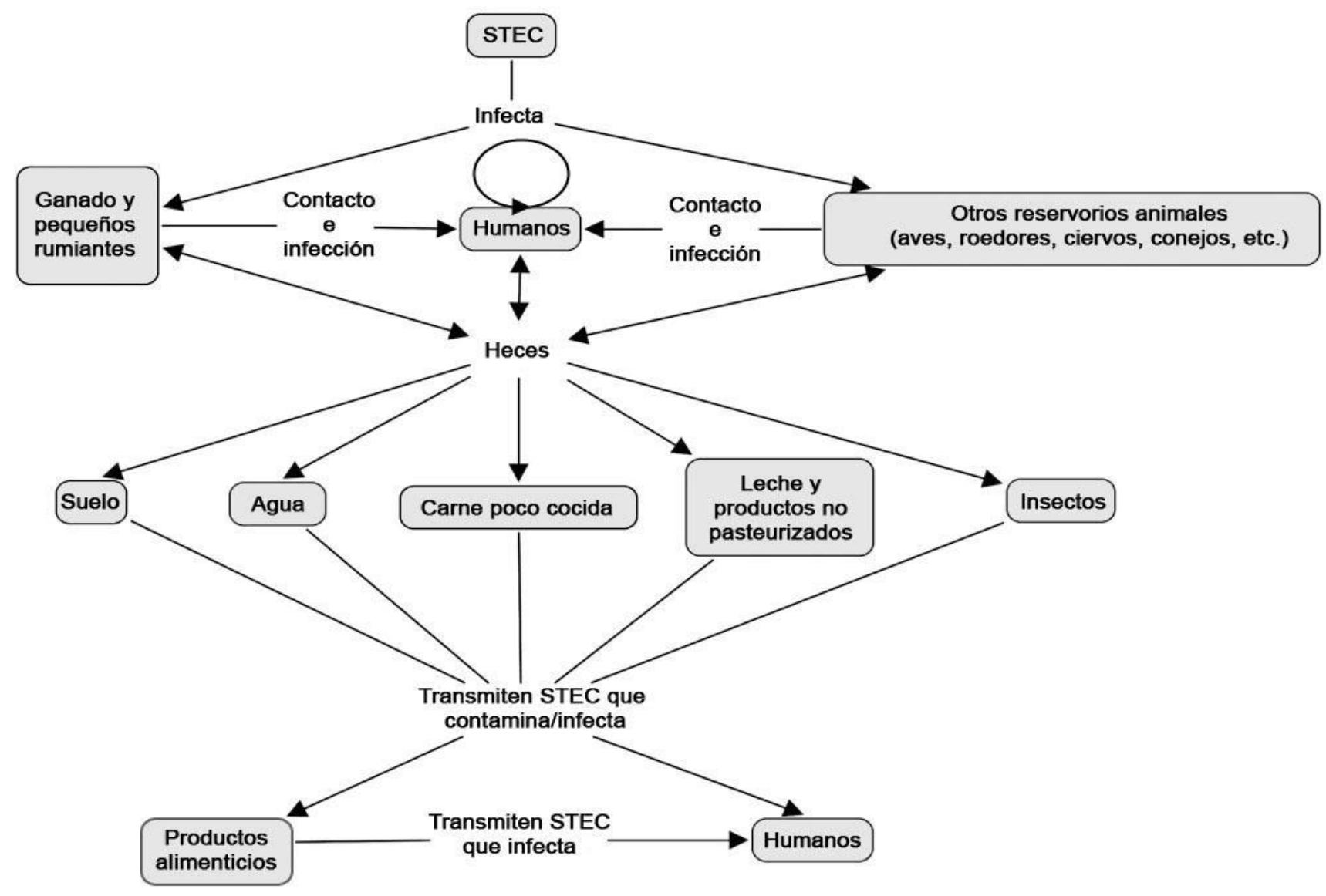

Fuente: Adaptado de García y col. 2010.

Figura 1.4. Mapa conceptual que ilustra las relaciones entre los factores involucrados en la transmisión de STEC. 


\section{La prevención es el camino: conservación de alimentos}

Debido a la falta de tratamientos específicos para esta patología, actualmente la problemática es abordada principalmente desde un punto de vista preventivo. En este sentido, juegan un rol clave las estrategias aplicadas por la industria alimentaria para controlar la contaminación con el patógeno, específicamente por el sector cárnico industrial, quien también sufre el impacto de esta problemática, ya que constituye una de las principales causas de retiro de productos del mercado ocasionando grandes pérdidas económicas.

Es oportuno destacar que actualmente los consumidores asumieron un papel crucial en la cadena de consumo, exigiendo mayores estándares de calidad y seguridad alimentaria.

Por todo lo expuesto, se entiende que la presente situación constituye una seria amenaza para la salud pública y una gran preocupación para la sostenibilidad de la industria cárnica, así como para toda la cadena de producción, por lo que urge implementar estrategias efectivas de conservación para erradicar este patógeno.

La conservación de alimentos es un área ampliamente estudiada que fue perfeccionando sus estrategias utilizadas a través de los años. En términos generales, las distintas estrategias de conservación de alimentos implican someter a los microorganismos contaminantes y patógenos a un ambiente hostil, con el fin de inhibir su crecimiento, acortar su supervivencia o causar su muerte. Las distintas respuestas de los microorganismos a este ambiente adverso determinarán su sobrevida o muerte.

La tecnología de obstáculos, introducida por Leistner (1978) se basa en inhibir el crecimiento microbiano y en retardar o evitar las reacciones deteriorantes de alimentos combinando los efectos de varios factores de preservación, los que, utilizados en forma individual (como métodos de conservación), deben aplicarse a niveles extremos causando generalmente una alteración de las características físicas, químicas y/o sensoriales del alimento.

La estabilidad microbiológica y por lo tanto la inocuidad de la mayoría de los alimentos procesados (nuevos y tradicionales), está basada en la combinación de diversos factores (obstáculos). Estos obstáculos controlan el desarrollo microbiano previniéndolo, retardándolo y/o incluso inactivando a los microorganismos (Leistner, 1995). La tecnología de los obstáculos o factores combinados implica exponer a los microorganismos a un ambiente adverso y de esta manera inhibir su crecimiento al interferir, mediante la combinación de factores, con 
su homeostasis. La homeostasis es la tendencia de los microorganismos a estabilizar su ambiente interno en respuesta a los factores externos. Si el equilibrio interno es modificado por los factores de preservación (actividad de agua, pH, temperatura, aditivos) utilizados en la formulación del alimento, los microorganismos dejarán de multiplicarse o lo harán a menor velocidad, canalizando su energía en reestablecer el equilibrio y en caso de no lograrlo incluso morirán. Los diversos obstáculos o factores de preservación tienen diferentes mecanismos de acción sobre los microorganismos; por lo tanto la estabilidad microbiológica puede lograrse con una inteligente combinación de los mismos (Leistner, 1995). El conocimiento de la influencia de cada uno de los obstáculos utilizados así como los efectos de la combinación de los mismos permitirá desarrollar procesos mínimos pero más efectivos para asegurar la estabilidad microbiológica de los alimentos.

Los principales agentes y/o condiciones utilizados como barreras u obstáculos para la conservación de alimentos son: la temperatura (alta o baja), la actividad del agua $\left(a_{w}\right)$, la acidez $(p H)$, el potencial redox (Eh), algunos aditivos químicos (por ejemplo, nitrito, sorbato, sulfito) y microorganismos competitivos (por ejemplo, microorganismos bioprotectores). Sin embargo, han sido descripto más de 60 obstáculos de uso potencial para conservación de alimentos (Leistner, 1999). La exposición de una población bacteriana a una sola intervención antimicrobiana, genera a menudo una respuesta heterogénea, dependiendo de la intensidad del tratamiento, así como muchos otros factores. Por el contrario, cuando se aplica una combinación de factores antimicrobianos, se producirán daños celulares múltiples, por lo que la célula incurre en costos de energía mucho más altos que llevan al agotamiento y muerte celular (Castellano y col., 2017). En este sentido, Leistner introdujo también el concepto de conservación multiobjetivo ("multitarget") de alimentos (Leistner, 1995), que consiste en el empleo de dosis menos drásticas de varios métodos de conservación que tendrian una mayor efectividad. Es decir, se podría lograr un efecto sinérgico si los obstáculos aplicados atacan simultáneamente diferentes objetivos (por ejemplo, membrana celular, material genético, sistemas enzimáticos, $\mathrm{pH}, a_{\omega}$, Eh, etc) dentro de las células microbianas (Leistner, 1995), llevando a muy bajas probabilidades de supervivencia y proliferación de las células expuestas, lo que permitiría el uso de dosis de tratamiento más bajas en comparación con su aplicación individual. El concepto de conservación multiobjetivo atiende también a los aspectos de calidad alimentaria, ya que la intensidad de las técnicas de preservación individuales puede mantenerse comparativamente baja, minimizando la pérdida de calidad global, mientras que el 
impacto en el crecimiento microbiano puede permanecer elevado, haciendo que los productos sean más aceptables que los obtenidos por métodos convencionales (Aguilera y Chirife, 1994).

En términos prácticos, esto significaría mayor efectividad al emplear diferentes obstáculos de pequeña intensidad que un factor conservador de mayor magnitud (Leistner, 1994), donde ningún obstáculo individual es único responsable de la inocuidad final del producto, por el contrario, ésta resulta del sinergismo obtenido por la combinación de los mismos (Aguilera y Chirife, 1994). El objetivo final es maximizar la actividad antimicrobiana, impidiendo la adaptación del patógeno, el desarrollo de resistencia o la protección cruzada al estrés aplicado (Sofos, 2008), sin afectar la calidad global del alimento. Sin embargo, esto solo podrá lograrse con éxito cuando se conozca totalmente la fisiología de los patógenos y los mecanismos de actividad antimicrobiana de diversos obstáculos.

\section{Alimentos cárnicos: un sustrato ideal para el crecimiento microbiano}

De acuerdo al Codex Alimentarius, se define como carne, a todas las partes de un animal que han sido dictaminadas como inocuas y aptas para el consumo humano o se destinan para este fin. Cualquiera que sea la especie de mamífero, el tejido muscular esquelético está estructurado en tres niveles organizativos principales: células musculares (también llamadas fibras) agrupadas en fascículos, que se reagrupan para formar un músculo esquelético.

La composición química del musculo esquelético comprende aproximadamente un $75 \%$ de agua, 19\% de proteínas, un bajo contenido de carbohidratos $(0,5 \%$ - 1,2\%), principalmente glucógeno y $2.5 \%$ de grasa. Además, el músculo contiene nitrógeno no proteico (aminoácidos, creatina, nucleósidos, vitaminas, etc.) y gran cantidad de compuestos inorgánicos (calcio, magnesio, potasio, sodio, hierro, etc.) que lo convierten en un excelente sustrato para el desarrollo de microorganismos (Fadda y col., 2012).

Las proteínas del músculo se dividen en tres grupos:

- Proteínas miofibrilares: conforman el aparato contráctil del músculo y son solubles en soluciones salinas concentradas. Las más abundantes son miosina y actina, que suponen el 65-70\% del total. El resto son las proteínas tropomiosina y troponina, importantes para la contracción, y distintas proteínas del citoesqueleto. 
- Proteínas sarcoplásmicas: solubles en agua o soluciones salinas diluidas, las cuales constituyen el $25-30 \%$ del contenido proteico total del tejido muscular. Se trata esencialmente de enzimas y mioglobina. Las enzimas necesarias para la glicólisis constituyen la mayor proporción de las proteínas sarcoplásmicas.

- Proteínas insolubles del tejido conjuntivo y de los orgánulos: el tejido conectivo que rodea las fibras musculares constituye la llamada matriz extracelular (MEC), la cual se divide en tres tipos según su ubicación con respecto a los niveles de organización musculares: (i) el endomisio, la capa más profunda en contacto con las fibras musculares, (ii) el perimisio que rodea a los fascículos, y (iii) el epimisio, la capa más externa en la superficie del músculo. Los tres tipos de MEC son muy similares y están compuestas por proteoglicanos y proteínas fibrosas, de las cuales el colágeno fibrilar I, III y IV son los componentes mayoritarios, mientras que difieren ligeramente en la proporción de laminina y elastina.

Aunque el músculo de los animales sanos se considera estéril, la carne proporciona un excelente ambiente para el crecimiento de microorganismos. Desde un punto de vista microbiológico, la propiedad más importante que presenta la carne es su elevado contenido en agua ( $a_{w} \sim 0,99$ ), lo que permite el crecimiento de la mayor parte de microorganismos. Además, en condiciones naturales, la carne presenta un $\mathrm{pH}$ post mortem cercano a la neutralidad (6-6,5), muy próximo al pH óptimo de crecimiento para un gran número de microorganismos patógenos y causantes de alteración. Estas condiciones, sumado al bajo potencial redox y temperatura de almacenamiento, lleva a la selección de microorganismos capaces de desarrollarse en ella, clasificándose los mismos en: i) Microorganismos de interés tecnológico, los que conducen la fermentación de ciertos productos cárnicos ya que poseen un importante efecto sobre la calidad organoléptica del producto final (Fadda y col., 2012), ii) Microorganismos deteriorantes, capaces de alterar las propiedades organolépticas del alimento y iii) Microorganismos patógenos, causantes de infecciones alimentarias (ETAs), que generalmente no modifican la apariencia del alimento.

La industria cárnica constituye actualmente, y desde hace muchos años, uno de los pilares más sólidos en la economía Argentina, encontrándose nuestro país, entre los de mayor producción y exportación de carne bovina hacia mercados internacionales. Por ello, la posible contaminación de estos productos con 
microorganismos patógenos no solo representa un potencial riesgo para la salud de los consumidores sino también para la sostenibilidad de este comercio local e internacional. Además, en los últimos 25 años, el mundo desarrollado ha experimentado un marcado cambio desde pequeños agricultores a operaciones de cultivo intensivo a gran escala. En tales operaciones existe un enorme potencial para la diseminación generalizada de patógenos zoonóticos, dando a un organismo emergente acceso a nuevos nichos o entornos.

\section{Estrategias tecnológicas para controlar la calidad sanitaria de la carne}

Los patógenos zoonóticos en la carne deben controlarse a través de un sistema completo y continuo conocido en la literatura como "de la granja a la mesa" (conocido en inglés como "From Farm to Fork") que implica la aplicación de intervenciones en distintas fases de este sistema:

Fase de Precosecha: La aplicación de intervenciones antimicrobianas en el campo, durante la cría del ganado, previas al sacrificio evita la entrada de patógenos en la cadena alimentaria. El estrés animal es un factor importante que puede afectar la salud del animal por alteración del equilibrio de su microbiota intestinal normal, la cual proporciona una protección adicional contra la colonización con patógenos. Algunos factores estresantes aparecen "naturalmente", por ejemplo, el parto y el destete, mientras que otros ocurren debido a la mala crianza de los animales, por ejemplo, vivienda inadecuada, cambios repentinos en la dieta y manejo rudo. Otro aspecto importante en la etapa de precosecha es la cría intensiva de animales, donde la convivencia muy próxima entre ellos resulta en una mayor transmisión horizontal de patógenos mediante aerosoles, contactos físicos frecuentes con superficies ambientales contaminadas, etc. Los bebederos de agua, utilizados por más de un animal y con falta de cloración, pueden servir también como fuente de infecciones y reinfecciones de los animales (Nørrung y Buncic, 2008). El tratamiento del estiércol (compostaje) es también un aspecto de gran importancia a tener en cuenta, ya que la propagación de estos residuos sin tratar para ser utilizado como fertilizantes en pastizales o tierras agrícolas, para la producción de cultivos, puede mediar infecciones o reinfecciones de animales a través del pastoreo contaminado, además de la posible contaminación de alimentos cosechados (Sofos, 2008). 
Entre las intervenciones tecnológicas para evitar la contaminación de la carne durante la precosecha se puede mencionar la manipulacion de la dieta de los animales mediante el uso de aditivos alimenticios o probióticos que pueden ser incorporados en la misma para lograr un efecto antagonista contra patógenos mediante la modificación de factores ambientales en el intestino, la producción de compuestos antimicrobianos o bien reducir la unión de patógenos a la mucosa intestinal. La vacunación de animales puede ser también una estrategia eficiente para la reducción de patógenos en esta etapa, por lo cual es actualmente un área de intensos estudios. Por ejemplo, en el Reino Unido la vacunación de aves contra Salmonella contribuyó a una reducción significativa del patógeno en la carne de aves (EFSA, 2004). Cabe destacar los avances obtenidos actualmente en el desarrollo de vacunas contra ECEH de aplicación animal dirigidas a disminuir su propagación en estos hospedadores y en el medio ambiente, y por ende en los seres humanos (Saeedi y col., 2017). Se han empleado diversos enfoques de vacunas, incluidas proteínas recombinantes, células avirulentas de E. coli O 157: H7, bacterias vivas atenuadas que expresan proteínas recombinantes, proteínas fimbriales recombinantes, etc. (Saeedi y col., 2017). Además de las vacunas basadas en proteínas, las vacunas de ADN estudiadas mostraron resultados prometedores en un modelo animal de laboratorio (Mehr y col., 2012). Hasta ahora, dos vacunas para ganado han recibido licencias condicionales y se han probado en ensayos de campo: Epitopix basada en tecnología SRP (del inglés "Siderophore Receptor and Porin"), receptor de sideróforo y proteínas porina que proporcionan los requisitos de hierro de las bacterias patógenas; y Echoniche, basada en proteínas asociadas al sistema de secreción tipo III (Thomson y col., 2009; Rich y col., 2010).

Fase de cosecha: esta fase comprende desde el momento del sacrificio animal hasta su distribución al comercio minorista. La contaminación de las canales (cuerpo del animal luego de la matanza) en el momento del sacrificio puede ocurrir de dos maneras: a través de animales vivos previamente infectados y/o contaminación cruzada de la canal en el entorno del sacrificio, siendo las principales fuentes de contaminación las heces, piel, pelo y el contenido intestinal de los animales. Previo al sacrificio, el ganado es mantenido en reposo con el objetivo de evitar cualquier situación de estrés para el animal. Posteriormente, el sacrificio o faena se inicia con el aturdimiento, cuya finalidad es insensibilizar al animal y evitar así el sufrimiento del mismo además de lograr su inmovilización para facilitar el corte de vasos sanguíneos en la posterior etapa de desangrado. Una vez concluido el sacrificio, la descontaminación inicial de la canal implica la aplicación secuencial 
de la limpieza con agua de la piel, la aspiración con vapor de manchas de la canal visiblemente sucias y finalmente la remoción de la piel del animal. Durante este proceso es esencial evitar el contacto de la piel con la parte interna estéril de la canal, así como también llevar a cabo la permanente esterilización de cuchillas utilizadas. Posteriormente se lleva a cabo la limpieza de la canal previa a la evisceración, la apertura y evisceración propiamente dicha, la limpieza final de la canal por pulverización con agua, y enfriamiento de canales evisceradas (Sofos, 2008). En el año 2013, la Autoridad Europea de Seguridad Alimentaria (EFSA) convalidó en el Reglamento (UE) 101/2013 el uso de ácido láctico para la descontaminación de superficies de reses y carne bovina. En Argentina, el SENASA, en base a dicho reglamento, decidió aceptar el empleo de ácidos orgánicos en los frigoríficos, modificando el Decreto 4.238/68. Además la Comisión Europea (CE) aprobó en 2013 el uso del ácido láctico para reducir la contaminación microbiológica en la superficie de canales de bovinos aplicado mediante pulverización o nebulización, en concentraciones comprendidas entre el $2 \%$ y el $5 \%$ de ácido láctico en agua potable (Lezzi y col., 2016). De hecho, la acción combinada de la pulverización de ácidos láctico y acético así como de $\mathrm{NaOH}$ ha sido exitosa en la reducción de Salmonella y en particular el nivel de E. coli 0157: H7 en cueros y carcasas (Carlson y col., 2008).

Dado que la temperatura es el factor más importante que afecta a la microbiota de la carne, el enfriamiento de las canales es la primera y una de las barreras más importantes, luego de las intervenciones de limpieza y evisceración, que se aplican rutinariamente para controlar el crecimiento de las bacterias deteriorantes y patógenas (Barco y col., 2015). Después de enfriar, las canales se cortan en diferentes partes. Las operaciones de corte y deshuesado de carne implican una manipulación y manejo relativamente intensivos de la carne, lo que aumenta notablemente el riesgo de contaminación cruzada a través de manos y utensilios (cuchillos, sierras, transportadores, etc.) así como también la transferencia de bacterias desde la superficie de la carne a las partes internas. Luego del corte y deshuesado, las canales son nuevamente lavadas con agua caliente y pulverizadas con ácido láctico y / o acético. En la siguiente Figura 1.5 se encuentran resumidas las principales etapas del proceso de faena y sus tratamientos descontaminantes aplicados. 
ETAPAS DEL PROCESO

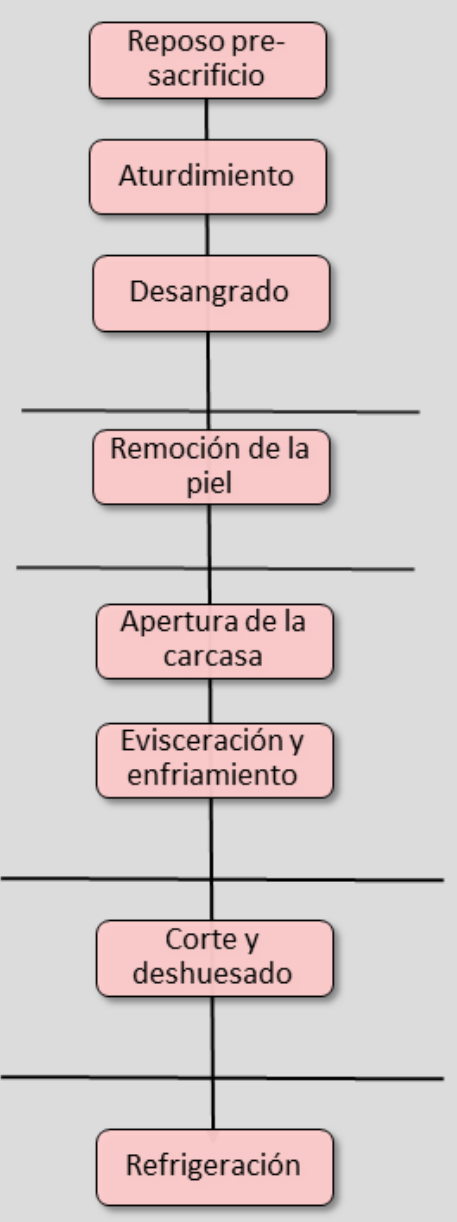

TRATAMIENTOS DESCONTAMINANTES

- Lavado con agua a elevada presión

- Aspiración con vapor

- Lavado con agua

- Lavado/pulverización con ácido láctico y/o acético

- Aspiración con vapor

- Lavado con agua caliente

- Lavado con agua caliente o agua a elevada presión

- Lavado/pulverización con ácido láctico y/o acético

Fuente: adaptado de L. Barco y col., 2015. Figura 1.5. Diagrama de flujo resumiendo las etapas de la línea de sacrificio de carne de res y sus respectivos tratamientos de descontaminación.

Este complejo proceso, al cual son sometidas las canales en el matadero, se encuentra controlado bajo el sistema de gestión de higiene de procesos obligatorio, basado en los planes de Análisis de Peligros y Puntos de Control Críticos (HACCP) (Bolton y col., 2001). Para la verificación de la efectividad del sistema basado en HACCP en mataderos, comúnmente se utilizan pruebas microbiológicas de canales. El Código Alimentario Argentino (CAA) establece como criterio que la carne picada y alimentos a base de carne picada vacuna, porcina y de aves listos y no listos para su consumo, deben hallarse libres de Salmonella spp. y de Escherichia coli O157:H7/NM. La determinación para estos microorganismos es ausencia/presencia (criterio obligatorio), mientras que el recuento de aerobios mesófilos, de Escherichia coli, de coliformes y de Staphylococcus aureus coagulasa positiva, funcionan como 
parámetros de evaluación del proceso tecnológico utilizado (criterio complementario).

Sin embargo, a pesar de los esfuerzos e intervenciones aplicadas en cada etapa del proceso de producción de la carne, evitar la contaminación de la canal con patógenos entéricos resulta una tarea aún muy difícil. Por ello, actualmente son numerosas las estrategias bajo estudio que intentan limitar el ingreso en la cadena productiva o bien lograr la inactivación de E. coli O 157:H7 en la carne durante esta etapa de cosecha.

Entre ellas podemos nombrar tecnologías físicas de conservación, como el procesamiento a altas presiones hidrostáticas (HPP) (Masana y col., 2015), el almacenamiento bajo vacio, la irradiación, campos eléctrico pulsantes, etc. Por otro lado, diversos tratamientos químicos son actualmente muy estudiados para la descontaminación de las carcasas. Además de los ácidos orgánicos, muchos otros productos químicos han sido evaluados, como el fosfato trisódico, que fue utilizado en Estados Unidos para la descontaminación de las canales de pollo, siendo éste considerado un producto CRAS (Kassem y col., 2017). También se estudió la utilización del dióxido de cloro (CDO) ( $\geq 100$ ppm) para controlar E. coli en cortes de carne, demostrando ser efectivo en la reducción del patógeno y actuando de forma sinérgica con el almacenamiento refrigerado (Visvalingam y Holley, 2018). Además de los distintos productos químicos, se evalúan también diversas estrategias de aplicación para optimizar su efecto. Así, Kassem y col. (2017) estudiaron el tratamiento mediante un sistema de inmersión con fosfato trisódico 10\%, ácido láctico $3 \%$ y decanoato de sodio 3\%, demostrando ser una intervención efectiva para reducir las bacterias patógenas sin afectar el color de la carne. En nuestro país, Signorini y col. (2018), evaluaron el efecto antimicrobiano de nueve intervenciones diferentes contra ECEH en carcasas de res en mataderos comerciales. Las mismas incluyeron diversos productos químicos (ácido cítrico, acético y láctico, agua caliente, ácido hipocloroso generado electrolíticamente y la combinación de ácido peroxiacético, octanoico, acético, peróxido de hidrógeno, peroxioctanoico) utilizados en distintas concentraciones y aplicados de forma manual 0 automatizada. Los autores concluyen que la descontaminación de las canales de res mediante la aplicación automatizada de ácido láctico 2\% y agua caliente reduce la contaminación por ECEH, y que la efectividad de las intervenciones mejoró utilizando el procedimiento automatizado ya que garantizaba la aplicación homogénea del producto en volúmenes adecuados. 
Fase poscosecha: esta etapa involucra el procesamiento y manipulación del alimento desde el comercio minorista hasta su consumo. Los principales factores de riesgo en esta etapa incluyen en primer lugar la contaminación cruzada de alimentos crudos hacia alimentos cocinados a través de vehículos como manos contaminadas, tablas de cortar, cuchillos y diferentes utensilios de uso doméstico, así como también la conservación simultánea de alimentos crudos (contaminados) y cocidos en heladeras. Otra fuente importante de contaminación es la refrigeración inadecuada de alimentos y sobre todo la cocción insuficiente de los mismos, así como también la recontaminación posterior a la cocción. En esta etapa poscosecha, la prevención de la contaminación se encuentra directamente relacionada con la aplicación de prácticas higiénicas durante la preparación de alimentos así como también la implementación de campañas preventivas y de concientización de la población en general.

Bioprotección: una alternativa natural

La investigación sobre el control biológico de bacterias patógenas a través de la cadena alimenticia de la carne ha proporcionado una amplia gama de opciones de tratamiento basadas en diferentes intervenciones antimicrobianas que involucran una combinación de obstáculos para la proliferación microbiana. En este sentido la preservación biológica o bioprotección, para garantizar la calidad higiénica de los alimentos, se ha convertido en una herramienta prometedora, la cual sería aplicada en la etapa de cosecha.

Se denomina bioprotección a la utilización de microorganismos antagonistas 0 sus productos metabólicos para controlar organismos indeseables (patógenos y contaminantes) con el fin de prolongar la vida útil y mejorar la seguridad de los alimentos, sin alterar las características sensoriales del producto final (Jordan y col., 20/4).

En este contexto, las bacterias lácticas (BL) tienen un papel central, siendo de gran interés tecnológico debido a su conocido potencial inhibitorio sobre microorganismos deteriorantes y patógenos de los alimentos. La utilización y aceptación de BL, como agentes bioprotectores, se fue consolidando entre los consumidores durante los últimos años. De hecho, hoy los consumidores exigen alimentos mínimamente procesados y sin agregados químicos, por lo que los 
métodos de conservación natural son actualmente mejor aceptados en comparación con tratamientos físicos o químicos. En este sentido, las BL recibieron el estatus CRAS (del inglés Generally Recognized As Safe) lo que implica un reconocimiento general de seguridad para el uso en alimentos además de su presencia natural en materias primas y alimentos fermentados (Wessels y col., 2004). Por ejemplo, Lactobacillus curvatus y Lactobacillus plantarum representan las poblaciones más importantes asociadas con carne refrigerada envasada al vacío y productos cárnicos fermentados (Castellano y col., 2010).

El conocido antagonismo de las BL hacia otros microorganismos se debe a la competencia directa por nutrientes y/o la producción de diferentes metabolitos antimicrobianos, como ácidos orgánicos, peróxido de hidrógeno y bacteriocinas (Woraprayote y col., 2016). En particular, al producir ácido láctico y por lo tanto reducir el pH, las BL inhiben el crecimiento de patógenos bacterianos e incluso, en algunos casos, producen su muerte (Atassi y Servin, 2010). Además, algunas BL producen bacteriocinas, péptidos de síntesis ribosomal con actividad antimicrobiana hacia microorganismos relacionados filogenéticamente, desempeñando un papel importante en la conservación de alimentos. Algunos tipos de bacteriocinas de BL son específicamente activas contra microorganismos Gram positivos causantes de deterioro y/o patógenos tales como Brochothrix termosphacta y Listeria monocytogenes (Uoraprayote y col., 2016). Sin embargo, se sabe que la mayoría de las bacteriocinas de BL no son efectivas contra microorganismos Cram negativos tales como ECEH. Aunque, en algunos casos, las bacteriocinas podrían ser activas en asociación con agentes tales como EDTA o ácidos orgánicos, que afecten la integridad de la membrana de los microorganismos Gram negativos (Belfiore y col., 2007; Prudêncio y col., 2015). Aunque el conocimiento sobre los péptidos antimicrobianos de cepas lácticas, ha aumentado exponencialmente durante los últimos 30 años, su aplicación en alimentos no ha tenido el mismo éxito. La legislación restrictiva relativa a los aditivos alimentarios, el espectro de inhibición limitado y los efectos de los componentes de los alimentos sobre la eficiencia podrian explicar la falta de aplicaciones industriales de bacteriocinas. Nisina es la única bacteriocina aprobada por la Administración de Medicamentos y Alimentos (FDA) para su uso en más de 50 países (Castellano y col., 2017). Por ello, la introducción de bacteriocinas en la matriz alimentaria mediante la producción in situ utilizando cultivos bioprotectores, constituye un enfoque alternativo factible. 


\section{Herramientas de vanguardia: la era de las ciencias «OMICAS»}

En los últimos años los avances tecnológicos han posibilitado explorar sin límites la biología y posicionarla como una ciencia de la información. Si bien antes del desarrollo de la genómica los científicos centraron sus investigaciones en grupos únicos o pequeños de genes o proteínas, las nuevas tecnologías surgidas en la era posgenómica plantean una visión global de los procesos biológicos, que se ve reflejada en el desarrollo de lo que se ha denominado como «La era ómica». El sufijo «-oma» tiene origen latino y significa «conjunto de». Las "ciencias ómicas" tiene por objeto el estudio de conjuntos biomoleculares particulares (ADN, ARN, proteínas o metabolitos secundarios) analizados mediante procedimientos de alto rendimiento. Es por ello que, la adición de este sufijo a diferentes estudios en biología, hace referencia a las aproximaciones masivas en las que se está enfocando la biología recientemente.

En este sentido, la genómica, la transcriptómica, la proteómica y la metabolómica, entre otras disciplinas ómicas, conforman líneas de estudio imprescindibles que han logrado avances extraordinarios en los campos de la salud, la biotecnología, la ecología y la industria de los alimentos. La cantidad de información obtenida con estas técnicas es tal, que sobrepasa el discernimiento humano, y por ello se valen de potentes técnicas estadísticas e informáticas para alcanzar la interpretación de los datos obtenidos, es decir, la bioinformática se convierte en una herramienta imprescindible detrás del desarrollo de cualquier ciencia ómica y necesaria para la integración de las mismas, constituyendo un desarrollo clave de la era posgenómica (Liebler, 2002).

El campo de la proteómica ayuda a establecer la conexión entre las secuencias del genoma y su comportamiento biológico, y puede definirse como el análisis del complemento proteico completo del genoma expresado en una célula o en cualquier muestra biológica en un momento dado bajo condiciones específicas (Champomier-Vergès y col., 2010). Dado que el genoma de un organismo es casi completamente estático mientras que el proteoma es altamente dinámico, la analogía de genoma y proteoma es solo superficial. El proteoma varía ya que no todas las proteínas se expresan al mismo tiempo ni en iguales cantidades; ocurriendo también modificaciones postraduccionales. Además diferentes tipos de células en organismos multicelulares expresan conjuntos especializados de proteínas, es decir, 
es probable que un genoma dado pueda dar lugar a un número infinito de proteomas (Champomier-Vergès y col., 2010).

Dentro del campo de esta disciplina, la proteómica diferencial tiene por objeto evaluar la expresión diferencial de las proteínas en una célula en diferentes condiciones (Graham y col., 2007). Ésta área demostró ser útil para evaluar cambios en los niveles de expresión de las proteínas expresadas por un organismo bajo determinadas condiciones de crecimiento (Lilley y col., 2002; De Angelis y col., 2016). La expresión de las diferentes proteínas es un reflejo del medioambiente en el que se encuentra el organismo. La proteómica aplicada a los microorganismos, ya sea en condiciones de laboratorio o en nichos similares a los alimentarios, contribuye a una mejor comprensión de las estrategias y/o mecanismos de adaptación microbiana y a la reconstrucción de vías metabólicas que permitirán seleccionar cultivos funcionales con capacidades optimizadas. De manera que la aplicación de esta tecnología, así como la combinación de otros enfoques "ómicos", constituye una herramienta de gran utilidad para la mejora de los alimentos ya existentes, o para el desarrollo de nuevos alimentos, permitiendo profundizar el conocimiento acerca de la capacidad de los cultivos microbianos seleccionados para competir y producir metabolitos de interés tecnológico o para la salud.

El desarrollo de la proteómica ha sido facilitado por los avances alcanzados en los métodos de separación de proteínas, la espectrometría de masa (MS, del inglés Mass Spectrometry), la secuenciación y anotación de los genomas, y los algoritmos de búsqueda de proteínas (Thelen, 2007). En la década del 90, la electroforesis bidimensional en geles de poliacrilamida (E2D) seguida de la identificación por espectrometría de masa eran las técnicas predilectas para el estudio de los cientos de proteínas expresadas en un organismo y en una determinada condición (Cil y Monteoliva, 2014). No obstante, aún hoy, la E2D es una técnica muy utilizada por su gran versatilidad (buena resolución, capacidad de separar proteínas de muestras complejas, reproducibilidad, carácter cuantitativo, entre otras). Sin embargo, los métodos modernos en el área de la proteómica han evolucionado desde las técnicas dependientes de geles a las técnicas libres de geles conocidas como proteómica "shotgun". Esta última emplea sistemas nano-HPLC en conjunto con espectrómetros de masa de alta resolución que posibilitan la caracterización proteica a gran escala con un alto rendimiento (Yang y col., 2015; Semanjski y Macek, 2016), obteniendo información no accesible mediante el uso de técnicas de separación basada en geles. 


\section{Problemática y relevancia del estudio}

Escherichia coli enterohemorrágica (ECEH) es un patógeno alimentario, transmitido principalmente a través de productos cárnicos y causante del Síndrome Urémico Hemolítico, principal causa de insuficiencia renal aguda en niños en Argentina, siendo a nivel mundial, el país con mayor incidencia de esta patología. Por ello, ECEH constituye una gran preocupación para la sostenibilidad de la industria de la carne y una grave amenaza para la salud pública.

Por otra parte, las exigencias actuales de los consumidores por alimentos más seguros, naturales y menos elaborados son cada vez mayores.

Surge en este contexto la necesidad de aportar, desde el ámbito científico, soluciones inmediatas para limitar y prevenir riesgos futuros.

En este sentido, las bacterias lácticas reconocidas como organismos seguros (CRAS), capaces de producir distintos tipos de metabolitos antimicrobianos, entre ellos las llamadas bacteriocinas, constituyen una estrategia biológica para ser utilizadas como biopreservantes. De hecho, en el mercado actualmente están disponibles algunos cultivos bioprotectores, especialmente contra Listeria monocytogenes. Sin embargo, no existen cultivos activos contra ECEH, ya que este patógeno es resistente a los péptidos antimicrobianos producidos por BL.

\section{Hipótesis}

Ciertas BL pueden controlar y/o inhibir el crecimiento de ECEH en la carne a través de la interacción directa o indirecta con el patógeno, posiblemente afectando su adhesión y/o anclaje a proteínas de la MEC. El estudio de esta interacción permitirá el desarrollo de un cultivo bioprotector activo contra ECEH y de uso seguro en alimentos, ya que no actuará como un agente inductor del bacterófago W933 de ECEH, evitando así la producción y liberación de partículas virales y/o de toxina shiga en el alimento cárnico.

El empleo de nuevas tecnologías como la proteómica aplicadas al estudio de la expresión de genes/proteínas bacterianos involucrados en las interacciones celulares permitirán conocer los mecanismos involucrados en la acción antagónica de microorganismos beneficiosos como las BL sobre el patógeno. 


\section{Objetivo general}

En el contexto planteado, se propone como objetivo general de esta tesis doctoral, la búsqueda de cepas de BL con acción inhibitoria sobre ECEH, estudiando la interacción entre ambos microorganismos a fin de comprender las bases moleculares involucradas en la acción antagonista. Se espera proporcionar a la industria cárnica bovina, una solución biotecnológica con base científica sólida para reducir la incidencia de ECEH basada en el uso de BL bioprotectoras.

\section{Objetivos específicos}

En base al objetivo general se plantearon los siguientes objetivos específicos:

OEI: CARACTERIZAR MOLECULARMENTE E. coli NCTC 12900 Y SELECCIONAR BL CON POTENCIAL INHIBITORIO SOBRE EL PATÓGENO

- Caracterización de la cepa modelo a utilizar, E. coli O157:H7 NCTC 12900: detección de genes relacionados a la virulencia mediante PCR

- Selección de BL de interés tecnológico con capacidad inhibitoria sobre ECEH:

- Ensayos de inhibición en placa

- Cocultivos (BL-ECEH) en Sistema Cárnico Modelo (SCM)

\section{OEII: ESTUDIAR LA INTERACCION BL - ECEH in vitro}

- Estudios proteómicos de la interacción BL - ECEH (análisis de expresión diferencial)

- Estudio de adhesión celular: ensayos de unión a Matriz Extracelular (MEC) (BL - ECEH)

- Efecto de BL sobre el bacteriófago W933 y su implicancia en la liberación de Stx por ECEH

- Evaluación de la actividad antilisteria de Ent. mundtii CRL35 durante el cocultivo con ECEH en ambiente cárnico

\section{OEIII: ANALIZAR LAS INTERACCIONES MICROBIANAS EN AMBIENTE CÁRNICO}

- $\quad$ Estudios fisiológicos en carne molida: $\mathrm{pH}$ y recuento bacteriano

- $\quad$ Estudios proteómicos en carne molida

- Evaluación de la actividad antilisteria de Ent. mundtii CRL35 en carne molida 


\section{CARACTERIZACIÓN MOLECULAR DE}

E. coli O157:H7 NCTC12900

Y EVALUACIÓN DEL POTENCIAL INHIBIDOR DE

CEPAS LÁCTICAS PRESELECCIONADAS
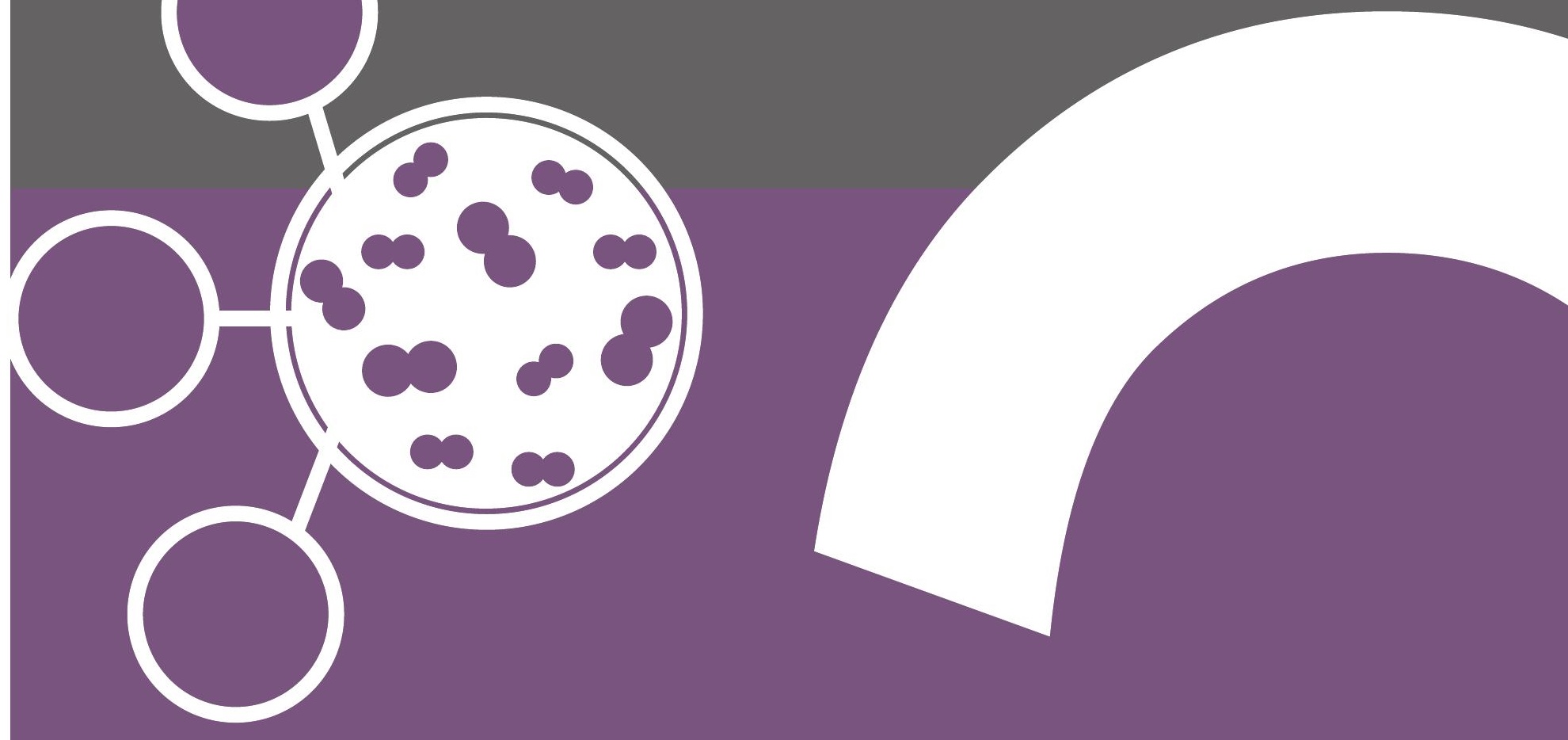


\section{CAPÍTULO 2 \\ CARACTERIZACIÓN MOLECULAR DE E. coli O 157:H7 NCTC12900 Y EVALUACIÓN DEL POTENCIAL INHIBIDOR DE CEPAS LÁCTICAS PRESELECCIONADAS}

\section{Introducción}

La cepa NCTC12900 de E. coli O 157: H7 es un aislado de origen natural caracterizado por no producir toxinas tipo Shiga. La misma se aisló en un laboratorio de salud pública de Austria durante 1992 y fue descripta anteriormente por Best y col. (2003). Con el fin de utilizarla como modelo seguro de estudio de cepas ECEH, en este trabajo de tesis se analizó en primer lugar sus características moleculares. Esto fue realizado mediante detección de genes claves de virulencia empleando la técnica de PCR (del inglés, Polymerase Chain Reaction, "Reacción en Cadena de la Polimerasa"). Luego se iniciaron los desafios (ensayos de inhibición en placa y cocultivos en SCM) de dicha cepa con cada una de las tres cepas lácticas preseleccionadas por sus propiedades tecnológicas a fin de encontrar entre ellas la mejor alternativa bioprotectora con capacidad para combatir el patógeno en alimentos cárnicos.

Las bacterias lácticas empleadas para este estudio fueron: I) L. curvatus CRL705, aislado de embutidos artesanales argentinos, productor de dos tipos de bacteriocinas con probada eficiencia bioprotectora en alimentos cárnicos: lactocina 705 (capaz de inhibir Brochothrix thermosphacta y ciertas bacterias lácticas) y lactocina AL705 antilisteria (Castellano y col., 2003; Castellano y Vignolo, 2006), y cuyo genoma ha sido secuenciado parcialmente (Hebert y col., 2012). II) L. plantarum CRL681 aislado de embutidos argentinos resulta de interés como potencial cultivo bioprotector por su alta capacidad acidogénica, efecto que sería esencial para la inhibición de ECEH; además de propiedades tecnológicas importantes tales como actividad peptidasa, degradación de aminas biogénicas in vitro y ausencia de actividad descarboxilasa de aminoácidos que impacta beneficiosamente en la seguridad de productos cárnicos (Fadda y col., 2010). III) Enterococcus mundtii CRL35, aislada de queso artesanal de Tafí del Valle, productora de una bacteriocina, enterocina CRL35, con actividad antagónica 
frente a Listeria monocytogenes y con propiedades antivirales (Wachsman y col., 1999). Se ha secuenciado su genoma y se están analizando sus propiedades tecnológicas más relevantes (Bonacina y col., 2014).

Si bien esta cepa no fue aislada de un nicho cárnico, estudios previos acerca de su potencial tecnológico justifican su aplicación en este ecosistema (Orihuel y col., 2018). 


\section{Caracterización de factores de virulencia de la cepa modelo E. coli O 157:H7 NCTC12900 mediante PCR}

\section{Resultados}

Se evaluó la presencia de genes de virulencia claves de este patotipo (ver Tabla 6.2, Capítulo 6 Materiales y Métodos) mediante PCR, en dos cepas de E. coli enterohemorrágica O 157: H7: NCTC 12900, cepa en estudio y E. coli EDL 933, cepa toxigénica de referencia aislada de carne de hamburguesa, utilizada ésta última como control positivo. Los genes investigados fueron los siguientes:

- gadA (glutamato descarboxilasa alfa): gen utilizado junto con genes de virulencia para detectar grupos patogénicos de E. coli.

- stx 1 (toxina shiga I): gen codificante de la toxina shiga I y presente en bacteriófago lisogénico.

- eaeA (intimina): ubicado en la isla de patogencidad LEE, codifica la principal adhesina participante de la lesión A/E ocasionada sobre enterocitos.

- hlyA (hemolisina): codificada en el plásmido $\bigcirc 157$ y causante de lesiones extraintestinales.

Como se observa en la imagen del gel obtenido (Figura 2.1), los genes gadA y eaeA fueron amplificados en ambas cepas. En la cepa control E. coli EDL933 además fue amplificado el gen stxl, mientras que, como se esperaba, éste estuvo ausente en E. coli NCTC 12900. Por otro lado, se observó que el gen que codifica para la hemolisina solo fue amplificado en la cepa E. coli NCTC 12900 (Tabla 2. 1). 


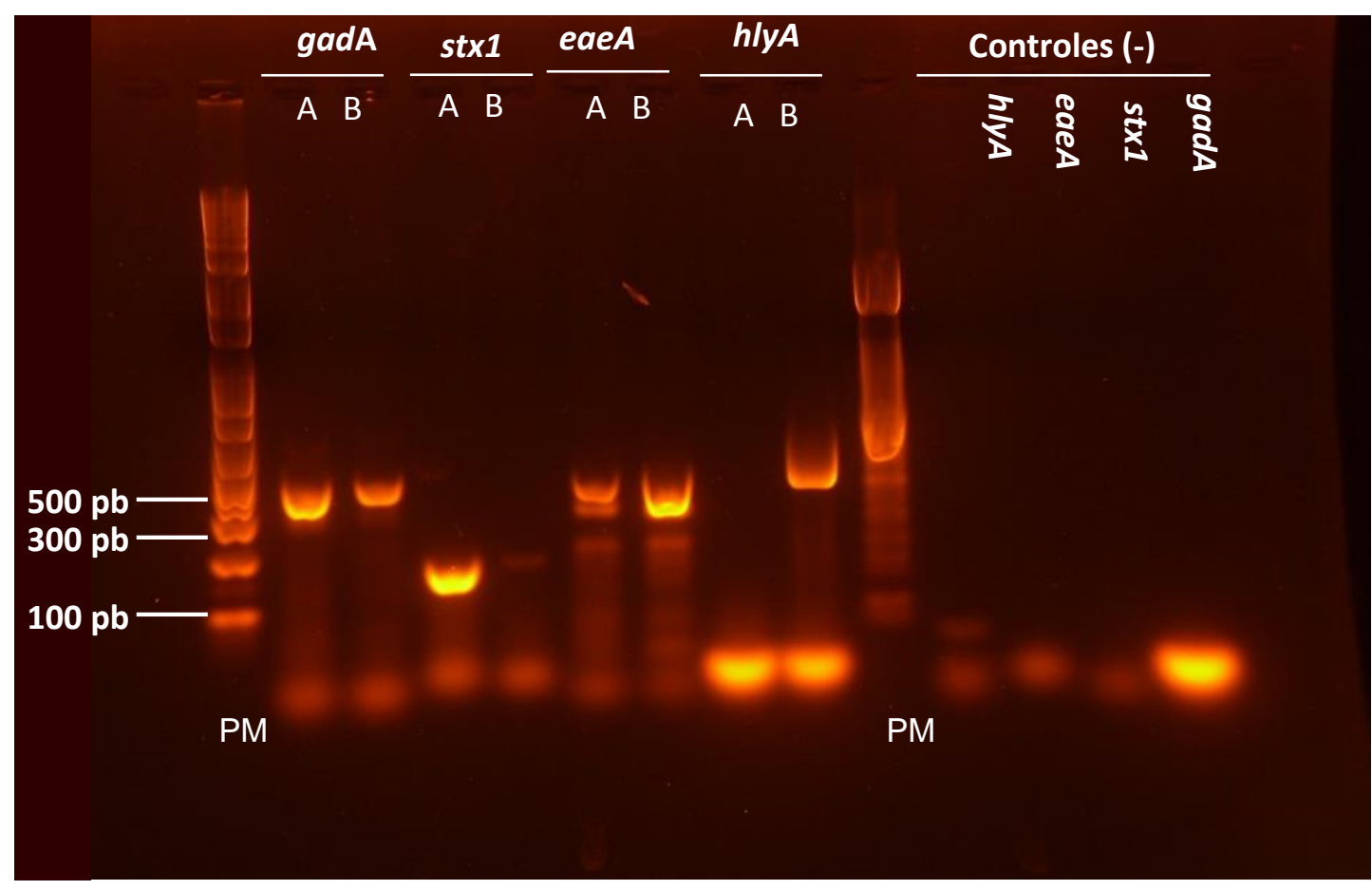

Figura 2.1. Fotografía del gel de agarosa. Se observan los fragmentos obtenidos luego de la amplificación por PCR. La identidad de cada banda se indica en la parte superior del gel, donde (A) corresponde a los productos de PCR obtenidos a partir del genoma de E. coli EDL933 y (B) a E. coli NCTC 12900.

Tabla 2.1. Presencia (+) o ausencia (-) de los genes amplificados por PCR en la cepa control (A) y de la cepa en estudio (B).

\begin{tabular}{ccc}
\hline \hline Gen & E. coli 933 (A) & E. coli NCTC 12900 (B) \\
\hline gadA & + & + \\
stx 1 & + & - \\
eaeA & + & + \\
\hline hlyA & - & + \\
\hline
\end{tabular}

Los fragmentos de ADN obtenidos fueron secuenciados y las secuencias nucleotídicas obtenidas (ver sección Anexo Capítulo 2) se analizaron usando BLASTn (The Basic Local Alignment Search Tool) del NCBI. Los resultados se muestran en la siguiente tabla: 
Tabla 2.2. Resultados obtenidos tras el análisis mediante BLASTn de las secuencias nucleotídicas obtenidas.

\begin{tabular}{|c|c|c|c|c|c|}
\hline $\begin{array}{l}\text { MUESTRA } \\
\text { ENVIADA }\end{array}$ & MUESTRA & $\begin{array}{c}\text { PROTEÍNA } \\
\text { IDENTIFICADA }\end{array}$ & ID & IDENTIDAD & MICROORGANISMO \\
\hline Ec 933_gadA & $M I_{w}$ & $\begin{array}{c}\text { glutamato } \\
\text { descarboxilasa } \\
\text { alfa parcial }\end{array}$ & $\begin{array}{c}\text { EKV723 } \\
40.1\end{array}$ & $99 \%$ & E. coli 88.1042 \\
\hline Ec 933_gadA & Ml_gadARv & $\begin{array}{l}\text { glutamato } \\
\text { descarboxilasa } \\
\text { alfa parcial }\end{array}$ & $\begin{array}{c}\text { KCP4 } 16 \\
88.1\end{array}$ & $100 \%$ & E. coli \\
\hline $\begin{array}{c}\text { Ec 12900_ga } \\
\text { dA }\end{array}$ & $\underset{w}{M 2 \_g a d A F}$ & $\begin{array}{l}\text { glutamato } \\
\text { descarboxilasa } \\
\text { alfa parcial }\end{array}$ & $\begin{array}{c}\text { EKV723 } \\
40.1\end{array}$ & $99 \%$ & E. coli 88.1042 \\
\hline $\begin{array}{c}\text { Ec 12900_ga } \\
\text { dA }\end{array}$ & M2_gadARv & $\begin{array}{l}\text { glutamato } \\
\text { descarboxilasa } \\
\text { alfa parcial }\end{array}$ & $\begin{array}{l}\text { KCPO8 } \\
080.1\end{array}$ & $99 \%$ & E. coli \\
\hline Ec 933_Stx 1 & M3_stx|Fw & $\begin{array}{c}\text { Verotoxina, } \\
\text { parcial }\end{array}$ & $\begin{array}{c}\text { AKL7 } 12 \\
35.1 \\
\end{array}$ & $100 \%$ & E. coli \\
\hline Ec 933_Stx 1 & M3_stxIRv & $\begin{array}{l}\text { Verotoxina, } \\
\text { parcial }\end{array}$ & $\begin{array}{c}\text { AKL7 12 } \\
35.1\end{array}$ & $100 \%$ & E. coli \\
\hline $\begin{array}{c}\text { Ec 12900_hly } \\
\text { A }\end{array}$ & M4_hlyAFw & $\mathrm{nd}^{*}$ & - & - & - \\
\hline $\begin{array}{c}\text { Ec 12900_hly } \\
\text { A }\end{array}$ & M4_hlyARv & Hemolisina & $\begin{array}{c}\text { UP_000 } \\
217735 . \\
1\end{array}$ & $99 \%$ & E. coli \\
\hline Ec 933_eaeA & M6_eaeAFw & $\begin{array}{c}\text { proteína de } \\
\text { unión y borrado, } \\
\text { parcial }\end{array}$ & $\begin{array}{c}A K L 712 \\
41.1\end{array}$ & $100 \%$ & E. coli \\
\hline Ec 933_eaeA & M6_eaeARv & $\begin{array}{c}\text { proteína de } \\
\text { unión y borrado, } \\
\text { parcial }\end{array}$ & $\begin{array}{c}\text { AKL } 712 \\
41.1\end{array}$ & $99 \%$ & E. coli \\
\hline $\begin{array}{c}\text { Ec } \\
\text { 12900_eaeA }\end{array}$ & M7_eaeAFw & $\begin{array}{c}\text { proteína de } \\
\text { unión y borrado, } \\
\text { parcial }\end{array}$ & $\begin{array}{c}\text { AKL } 712 \\
41.1\end{array}$ & $97 \%$ & E. coli \\
\hline $\begin{array}{c}\text { Ec } \\
\text { 12900_eaeA }\end{array}$ & M7_eaeARv & $\begin{array}{c}\text { proteína de } \\
\text { unión y borrado, } \\
\text { parcial }\end{array}$ & $\begin{array}{c}\text { AKLL7 } 12 \\
41.1\end{array}$ & $99 \%$ & E. coli \\
\hline
\end{tabular}

*nd: no determinada. Este gen (hlyA) está presente en la cepa E. coli NCTC12900, sin embargo no se obtuvo con éxito la secuenciación del cebador reverse

\section{Discusión}

A través de los resultados obtenidos en el presente trabajo de tesis doctoral se confirmó que E. coli NCTC 12900 posee los genes de virulencia característicos del patotipo ECEH (gadA, eaeA y hlyA). Sin embargo, a pesar de ser una cepa patogénica, la ausencia del gen stx l, reafirma que se trata de una cepa de ECEH atoxigénica, lo cual la hace inocua para su manipulación. Estos resultados coinciden con los obtenidos por Ayaz y col. (2014) quienes realizaron una caracterización molecular de los principales genes de virulencia y adherencia de aislados de E. coli 
O 157:H7 de ganado bovino en Turquía y utilizaron NCTC12900 como control. Nuestros resultados permiten confirmar que la cepa E. coli NCTC 12900 constituye un adecuado modelo de estudio de ECEH, siendo una mutante que cuenta con los genes de virulencia característicos del patotipo pero sin capacidad de producir y liberar la toxina tipo shiga, lo que permitió llevar a cabo los estudios propuestos, sin implicancias en bioseguridad.

A continuación, se utilizará la sigla "ECEH" para hacer referencia a la cepa $E$. coli NCTC12900. 


\section{Ensayos de inhibición en placa}

\section{Resultados}

El ensayo de inhibición del crecimiento de ECEH se realizó como primer enfoque para determinar el potencial inhibidor de tres cepas lácticas preseleccionadas frente al patógeno. Mediante este método rápido y simple, detallado en Materiales y Métodos (Capítulo 6), se evaluó la capacidad inhibidora de cada cepa BL contra ECEH, así como la naturaleza del efecto inhibidor. Los resultados obtenidos demostraron que las tres cepas de BL estudiadas mostraron un patrón inhibitorio similar, ya que los diámetros de los halos de inhibición del crecimiento de ECEH obtenidos fueron similares (Figura 2.2). Se observó además que, en general se registraron halos de inhibición en aquellas condiciones en las que las células de BL permanecían viables sin ser dañadas (Figura 2.2, condiciones 1 y 4), mientras que cuando las células fueron tratadas con lisozima, se observaron halos de inhibición de menor diámetro (Figura 2.2, condición 3). Por el contrario, no se observó inhibición cuando se utilizó células lisadas o sobrenadante libre de células (no tratado, calentado o calentado y neutralizado) conteniendo metabolitos tales como ácidos orgánicos, bacteriocinas termoestables y diferentes factores solubles (Figura 2.2, condición 5, 6 y 7). Finalmente, la presencia de halos de tamaño casi imperceptibles cuando se utilizó solución de ácido láctico al 4\% confirmó la conocida resistencia ácida de ECEH (Figura 2.2, condición 8). 


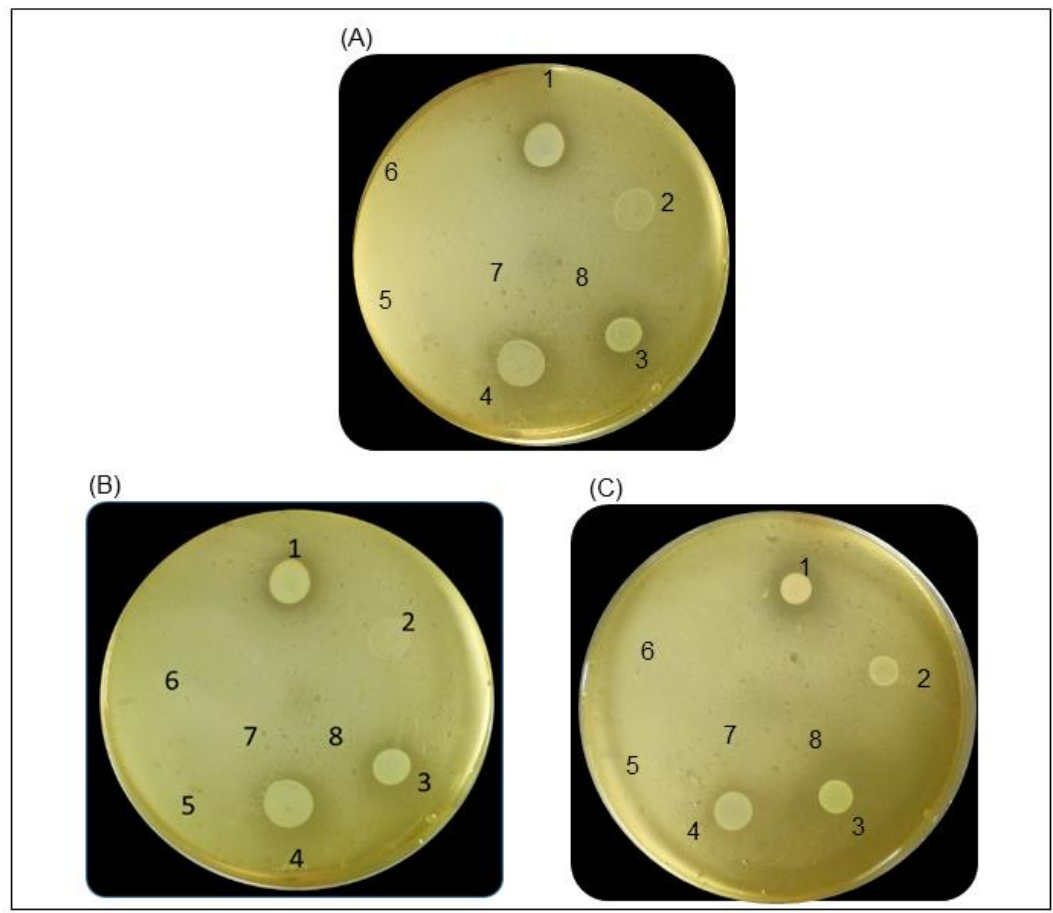

Figura 2.2. Inhibición del crecimiento celular de ECEH por las BL estudiadas: $L$. curvatus CRL 705 (A), Ent. mundtii CRL35 (B) y L. plantarum CRL 681 (C). Sobre un césped de ECEH se evaluaron diferentes condiciones de cada cepa láctica: I- células intactas / viables, suspensión de BL en solución fisiológica; 2- células no viables, suspensión de LB en agua destilada calentada durante 15 minutos a $95^{\circ} \mathrm{C}$; 3 - suspensión de $\mathrm{BL}$ tratadas con lisozima ( $\mathrm{mg} / \mathrm{mll}$; 4- cultivo activo de BL en medio MRS directo; 5- sobrenadante libre de células del cultivo de toda la noche calentado $\left(5 \mathrm{~min}, 95^{\circ} \mathrm{C}\right)$; 6- sobrenadante libre de células del cultivo toda la noche calentado $\left(5 \mathrm{~min}, 95^{\circ} \mathrm{C}\right.$ ) y neutralizado; 7 - sobrenadante libre de células del cultivo de toda la noche intacto; 8 -solución de ácido láctico al 4\%.

\section{Discusión}

Los resultados obtenidos a través de este ensayo, evidenciaron una actividad inhibidora variable de las cepas evaluadas, siendo dicho efecto independiente de la acción del ácido producido luego de la fermentación, de las bacteriocinas sintetizadas por cada una, o de algún metabolito soluble presente en el sobrenadante de cultivo ya que no mostró capacidad de inhibición (ausencia de halos) con ninguno de los tratamientos realizados al mismo (calentamiento y/o neutralización). En este sentido, el control de ácido láctico al 4\% utilizado, presentó halos de inhibición casi imperceptibles, siendo la concentración utilizada ampliamente mayor a la habitualmente producida por las bacterias lácticas $(0,5-2,5$ g/l) (Boontim y col., 2018). Además, incluso siendo todas las cepas de BL capaces de acidificar el medio sarcoplásmico (como se describirá en el siguiente ensayo), 
demostraron una actividad inhibidora diferente hacia el patógeno. Esto confirmaría que el efecto observado no responde a la presencia de ácido producido por las cepas lácticas durante su crecimiento. Por su parte, ECEH tiene tres poderosos sistemas de resistencia al estrés ácido descriptos; estos incluyen un sistema oxidativo inducido por ácido, un sistema dependiente de arginina inducido por ácido y un sistema dependiente de glutamato (Bearson y col., 2009). Estos tres sistemas de resistencia a ácidos tienen diferentes requisitos para su funcionamiento, lo que permite una superposición entre ellos, asegurando que al menos uno de ellos siempre estará activo para proteger la célula en un ambiente ácido (Bearson y col., 2009). Estas propiedades de ECEH están íntimamente relacionadas con las bajas dosis infecciosas registradas para este patógeno, ya que le permite atravesar la barrera de acidez gástrica asegurando que al menos un pequeño porcentaje de células pueda sobrevivir a la misma e infectar las células hospedadoras. Por lo tanto, su gran capacidad de resistencia a estrés ácido es un factor de virulencia de suma importancia y explica la ausencia de halos de inhibición al utilizar sobrenadantes de cultivo, observado en el ensayo realizado en este trabajo.

Sin embargo, Angmo y col. (2016) describieron que el bajo pH y la producción de ácido láctico fueron los principales factores para la inhibición del crecimiento de otra enterobacteria como Yersinia enterocolitica cuando estudiaron su inhibición en presencia de cepas de Lactobacillus. Estos resultados reflejan los diferentes niveles de tolerancia al estrés ácido entre distintas enterobacterias patógenas.

En cuanto a la inhibición de ECEH por acción de bacteriocinas de BL, se sabe que estos péptidos no actúan naturalmente sobre microorganismos Gram negativos a menos que su acción se combine con un tratamiento para permeabilizar la pared celular y permitir de esa manera la entrada de la bacteriocina a la célula (Castellano y col., 2011). Sin embargo, la efectividad de la bacteriocina internalizada dependerá del mecanismo de acción específico de cada péptido antimicrobiano. En este sentido, nuestros resultados muestran la ausencia de inhibición debido a las bacteriocinas producidas por Ent. mundtii CRL35 (enterocina CRL35) y L. curvatus CRL705 (lactocina 705) en las condiciones ensayadas.

Por otra parte, Cisneros y col. (2017) (comunicación personal) evaluaron mediante el ensayo de inhibición del crecimiento de ECEH en placa, el efecto del sobrenadante del cocultivo de una cepa láctica (con actividad anti ECEH) y ECEH, con el fin de evaluar si en presencia del patógeno, la BL expresaba algún factor soluble capaz de inhibir el crecimiento de mismo. La ausencia de halos inhibitorios 
debido al sobrenadante del cocultivo, indicó que la convivencia con el patógeno no induciría en la cepa láctica la liberación de ningún compuesto soluble capaz de inhibir el crecimiento de cepas ECEH.

En base a esto y a nuestros resultados se sugiere que la acción antagonista de las cepas BL hacia ECEH involucra otros mecanismos, como ser la competencia por nutrientes, implicando una estrecha relación célula-célula donde el cultivo bioprotector debe preservar su vitalidad para hacer frente e inhibir a ECEH.

\section{Desempeño de BL y ECEH en ambientes cárnicos}

\section{Resultados}

Cuando se estudió el crecimiento individual y en cocultivo de las cepas lácticas y ECEH en un sistema cárnico modelo (SCM), se observó que las tres cepas de $B L$ evaluadas lograron un máximo crecimiento individual aproximadamente a las 24-48 h, según la cepa (2.0 × 108- $9.8 \times 10^{8} \mathrm{UFC/ml}$ ) (Figura 2.3). Es de destacar que las cepas lácticas alcanzaron su crecimiento exponencial luego de 3-8 h de incubación llegando a fase estacionaria aproximadamente a las 24 h (Figura 2.3). Posteriormente, estas cepas mantuvieron su viabilidad inicial hasta las $96 \mathrm{~h}$ de incubación alcanzando valores próximos a 1 × $10^{6} \mathrm{CFU} / \mathrm{ml}$ (Figura 2.3). Por otro lado, se observó que todas las cepas de BL creciendo individualmente produjeron un descenso significativo del pH del medio, siendo las cepas CRL705 y CRL35 las que mostraron mayor disminución de dicho valor (Figura 2.3, A y B respectivamente). Cuando se inoculó ECEH de forma individual, se observó una cinética de crecimiento microbiano tradicional. Entre las 4 y 6 h alcanzó el crecimiento exponencial, llegando a fase estacionaria, con la máxima viabilidad celular, a las $24 \mathrm{~h}\left(1.8 \times 10^{8} \mathrm{UFC} / \mathrm{ml}\right)$ (Figura 2.4).

Cuando se analizó el crecimiento en cocultivo de cada BL con ECEH, se evidenció una cinética de crecimiento diferente para ambos microorganismos en comparación con su crecimiento individual en SCM (Figura 2.3). Se observó un crecimiento disminuido de las cepas de BL en presencia de ECEH, alcanzando 1-2 unidades logarítmicas menos de viabilidad celular que en la condición de cultivo simple, dependiendo de la cepa (Figura 2.3). Sin embargo, durante el cocultivo con ECEH, todas las BL pudieron mantener el estado estacionario hasta el final de la incubación, con una población similar al inicio del ensayo $\left(10^{6}-10^{7} \mathrm{UFC} / \mathrm{ml}\right)$ (Figura 
2.3). Cabe destacar que el potencial acidificante de las cepas BL no se vio afectado por la presencia del patógeno, alcanzando valores similares a los observados en cultivos puros (pH final entre 4,5 y 3,7) (Figura 2.3). Además, el crecimiento del patógeno en cocultivo se vio afectado considerablemente por la presencia de BL, específicamente después de las primeras $8 \mathrm{~h}$. Particularmente, L. curvatus CRL705, produjo una ligera disminución de la población de ECEH, aproximadamente 0,6 unidades logarítmicas (Figura 2.3A), mientras que las cepas Ent. mundtii CRL35 y L. plantarum CRL68 1, mostraron un mayor efecto inhibidor (Figura 2.3B y C, respectivamente). De hecho, su presencia produjo una reducción significativa de la viabilidad de ECEH después de 8 h de crecimiento, acelerando la entrada de ECEH en la fase de muerte. A las 96 h, se observó una disminución significativa de los recuentos de UFC de la cepa ECEH alcanzando valores entre 2 y 5 unidades logarítmicas de disminución en los cocultivos que contenían Ent. mundtii CRL35 y L. plantarum CRL68 I, respectivamente (Figura 2.3B y C).

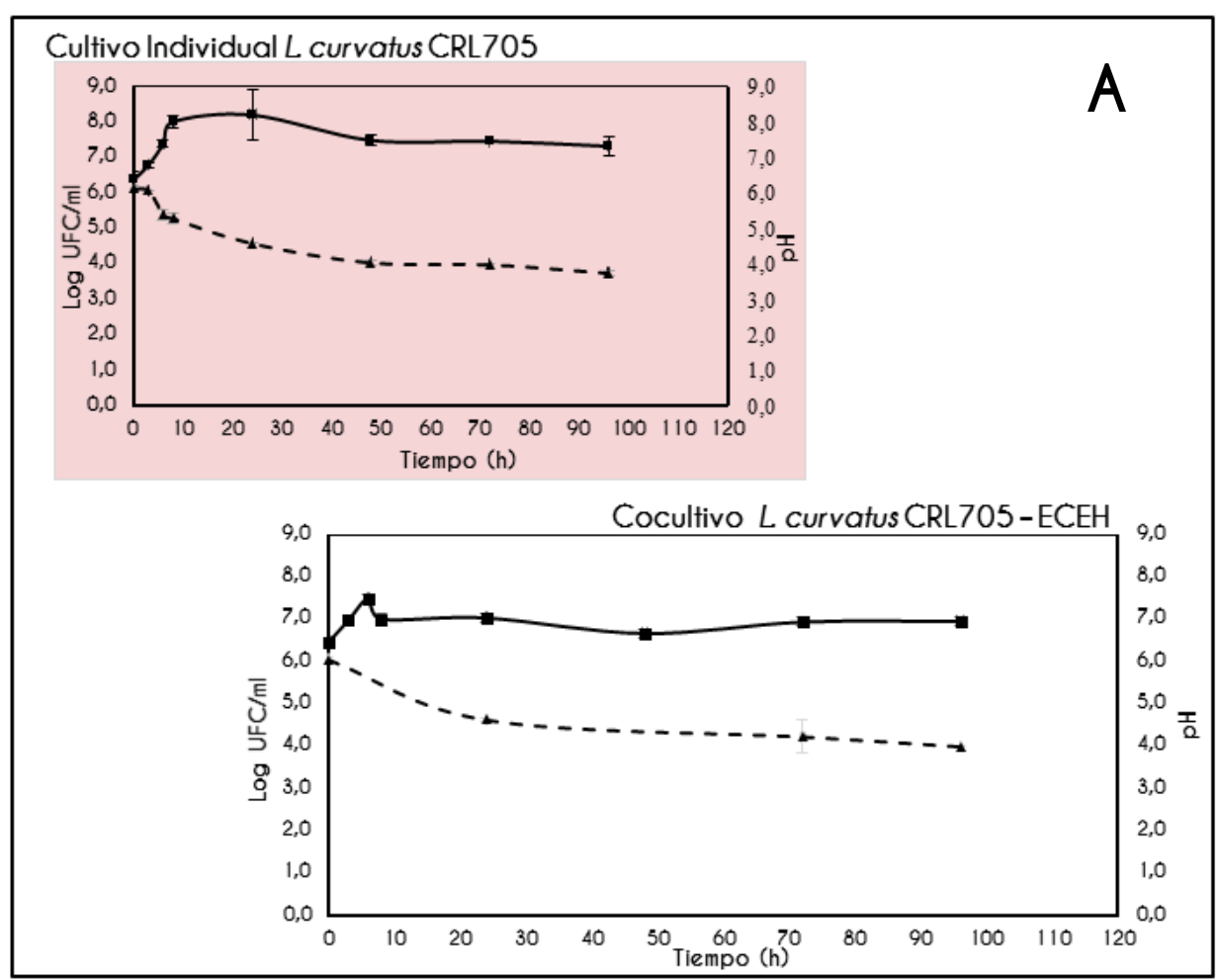



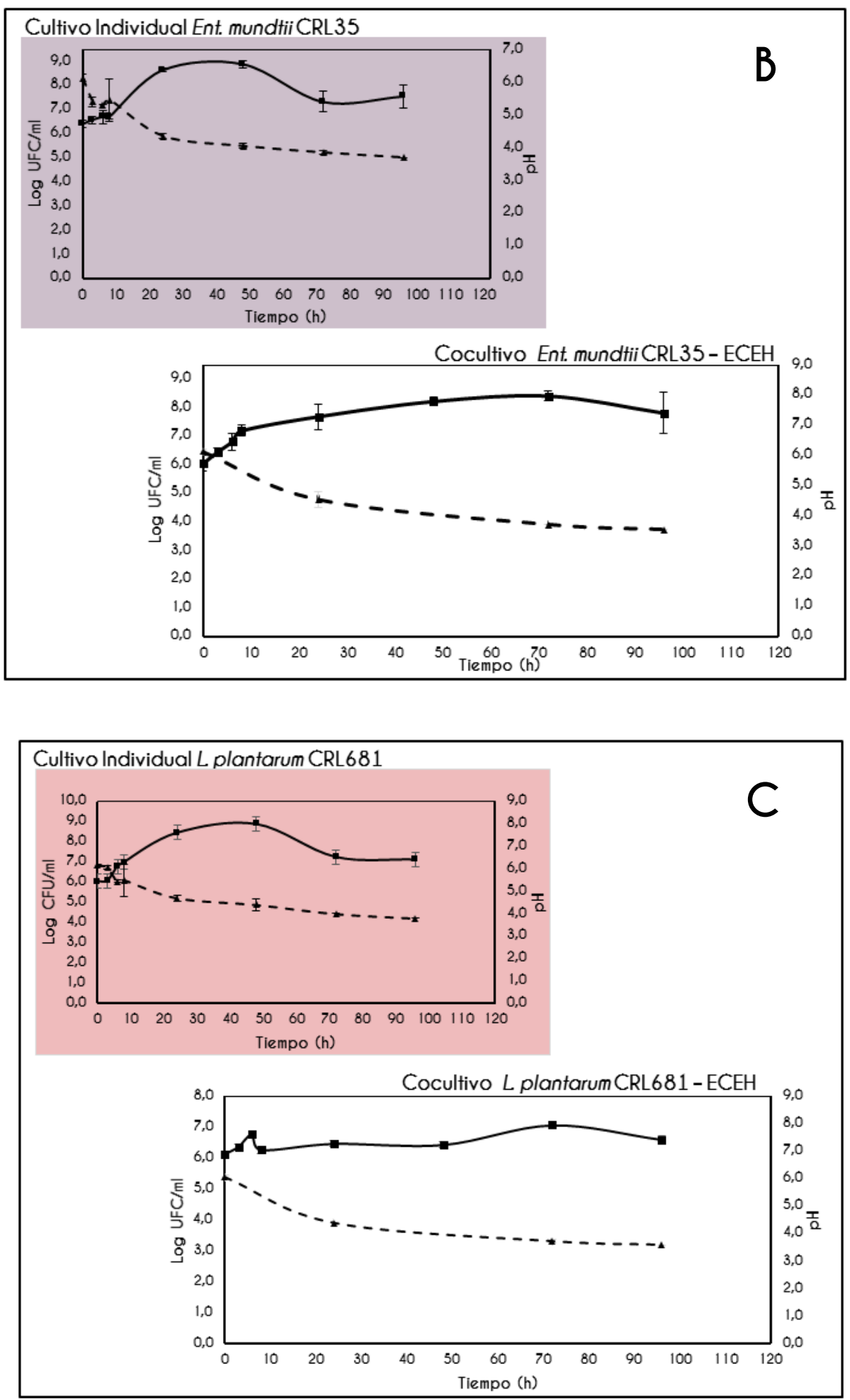

Figura 2.3. Crecimiento individual (panel superior) y crecimiento en cocultivo (panel inferior) de cada BL representado como Log de UFC/ml en SCM incubadas a $30{ }^{\circ} \mathrm{C}$ durante $96 \mathrm{~h}$. El valor de $\mathrm{pH}$ del medio determinado a lo largo del crecimiento en ambas condiciones se representa con línea negra discontinua. (A) Cultivo individual y cocultivo de L. curvatus CRL705, (B) Cultivo individual y cocultivo de Ent. mundtii CRL35, (C) Cultivo individual y cocultivo de L. plantarum CRL681. 


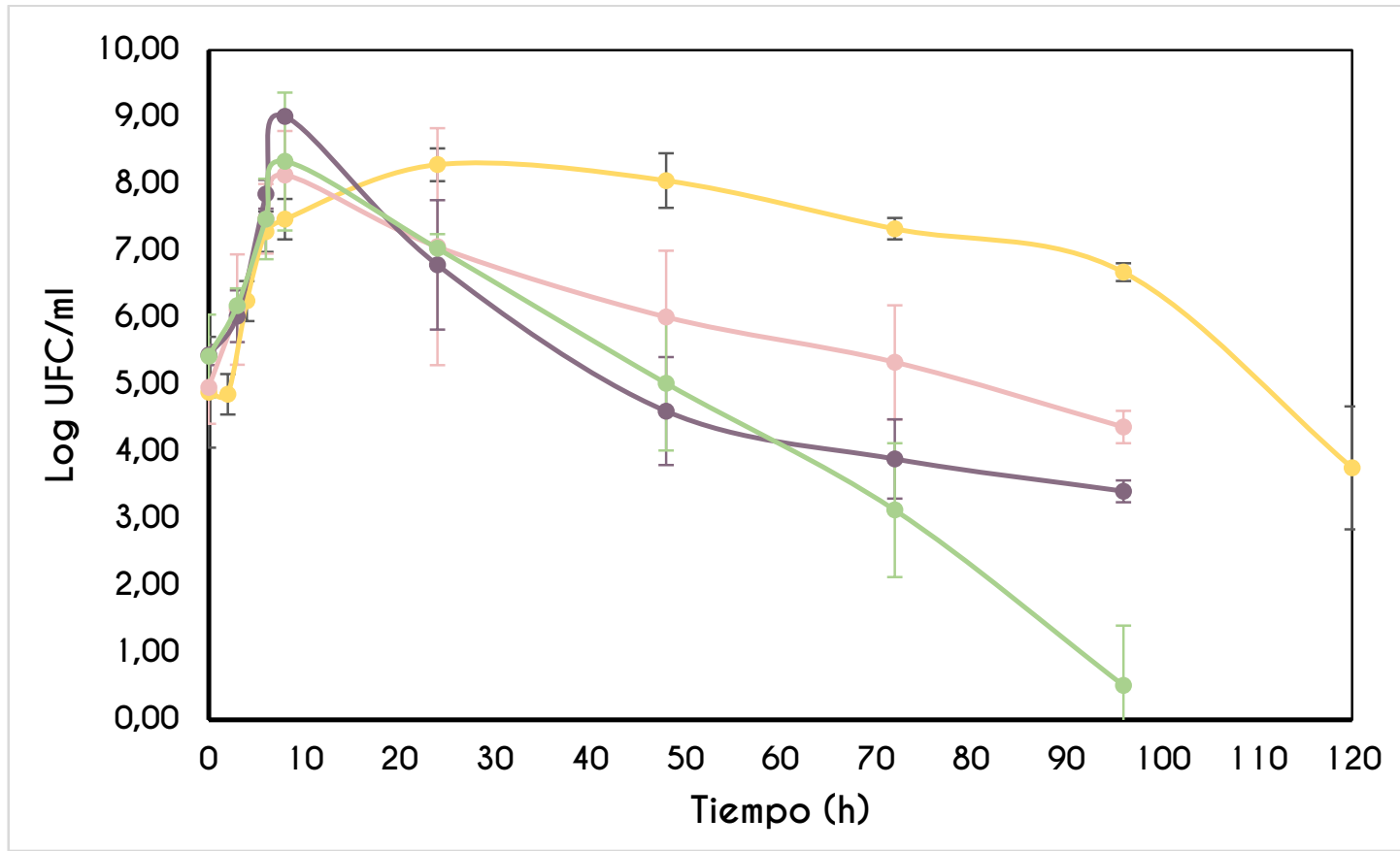

Figura 2.4. Crecimiento individual (línea amarilla) y crecimiento en cocultivo de ECEH con L. curvatus CRL705 (línea rosa), con Ent. mundtii CRL35 (línea violeta) y L. plantarum, CRL68 I (línea verde) representado como Log UFC/ml en SCM a $30^{\circ} \mathrm{C}$ durante $96 \mathrm{~h}$.

\section{Discusión}

Al analizar la cinética de crecimiento de los diferentes cocultivos BL-ECEH, se evidenció que las cepas BL evaluadas afectaron negativamente el crecimiento de ECEH en el ambiente cárnico, induciendo la entrada en fase de muerte del patógeno después de 8 h de incubación. En estos ensayos se evidenció un mayor potencial inhibidor de L. plantarum CRL681 y Ent. mundtii CRL35, los cuales lograron una disminución significativa de los recuentos de ECEH a las 96 h.

En un trabajo similar, Rios-Covian y col. (2015) informaron un crecimiento retardado de Bacillus fragilis por la presencia de Bifidobacterium longun en cocultivo durante las primeras 14 h. Además, observaron un crecimiento mejorado de bifidobacterias en comparación con el monocultivo correspondiente. Al evaluar la influencia recíproca entre ambos microorganismos en cocultivo, nuestros resultados mostraron que ECEH afectó levemente la densidad celular máxima lograda por cada BL, comparado con la mayor influencia que tuvo la cepa láctica sobre el crecimiento del patógeno. Concretamente, Ent. mundtii CRL35 durante el cocultivo con ECEH, adelantó su entrada en la fase exponencial de crecimiento y experimentó la estabilización de la fase estacionaria con una ligera disminución de la viabilidad 
después de 40 h en comparación con su crecimiento individual. Yang y col. (2017) al estudiar la coincubación de Bifidobacterium bifidum con Listeria monocytogenes, también informaron la entrada temprana en fase de crecimiento logarítmico, lo que sugiere un efecto promotor del crecimiento mutuo durante el cocultivo. Nuestros resultados no muestran un efecto de mutua promoción del crecimiento sino por el contrario una concreta inhibición del patógeno y una fase estacionaria más estable de la BL que durante su cultivo individual. 


\section{Anexo Capítulo 2}

Secuencias nucleotídicas de los genes amplificados por PCR para las cepas E. coli NCTC 12900 y E. coli EDL933

M1_gadAFw sequence exported from M1_gadAFw_2016-09-15.ab 1 SEQ DNAMAN I: 329 bp; Composition 67 A; 102 C; 91 C; 68 T; 1 OTHER Percentage: 20.4\% A; $31.0 \%$ C; $27.7 \%$ C; $20.7 \%$ T; 0.3\%OTHER Molecular Weight (kDa): ssDNA: 101.37 dsDNA: 202.86 ORICIN

I CCAAACCNCG TCTCCGGTCC GGTCCAAATC TCCTCGCATA AATTCCCTCG CTACTCGCAT

61 GTCGACCTCC GCCACATCCC TATCCGCCCC GGTCAGTTCT TTATCGACCC CAAACCCATC

121 ATTCAACCCT GCCACGAAAA CACCATCCCC GTCGTCCCCA CTTTCCGCGT GACCTACACC

181 CGTAACTATC AGTTCCCCCA ACCCCTCCAC GATCCACTCG ATAAATTCCA GCCCGACACC

241 CGTATCGACA TCGACATCCA CATCGACGCT GCCACCGGTC GCTTCCTCGC ACCGTTCCTC

301 CCCCCCGATA TCGTCTCCGA CTTCCCCCA

M1_gadARv sequence exported from M1_gadARv_2016-09-15.ab 1

SEQ DNAMAN5: 337 bp; Composition 68 A; 96 C; 90 C; 81 T; 2 OTHER

Percentage: $20.2 \%$ A; $28.5 \%$ C; $26.7 \% \quad$ G; $24.0 \%$ T; 0.6\%OTHER

Molecular Weight (kDa): ssDNA: 103.88 dsDNA: 207.78

ORIGIN

I CCACCCCTCG CNGCGTCCAT GTGCATCTCG ATCTCGATAC CGGTGTCCCC CTCCAATTTA

61 TCCAGTCCAT CGTCCACCGC TTCCGGCAAC TCATAGTTAC CGGTCTAGGT CACCCCCAAA

I21 GTCGCCACCA CGCCGATCGT GTTTTCGTCG CACGCTTCAA TCATCCGTTT CGCATCCATA

181 AACAACTCAC CGCCCCCCAT ACGGATCTCG CCCACCTCCA CATCCCAGTA CCCACCCAAT

241 TTATCCCACC ACATTTCCAC CCGACCCCAC ACCACGTTTC GTTTATCCGT TCGTTTCCCT

301 CCACCTTCCA TACGCTTNCC AACCCCATTT CATCAAA

>M2_gadAFw sequence exported from M2_gadAFw_2016-09-15.ab 1 SEQ DNAMAN7: 325 bp; Composition 65 A; 101 C; 91 C; 68 T; 0 OTHER Percentage: 20.0\% A; $31.1 \%$ C; $28.0 \%$ C; $20.9 \%$ T; 0.0\%OTHER Molecular Weight (kDa): ssDNA: 100.1 4 dsDNA: 200.39 ORICIN I ACCTCGTCTC CCOTCCCGTG CAAATCTCCT GCCATAAATT CGCCCCCTAC TCGCATCTCC 
61 AGCTCCGCGA GATCCCTATC CGCCCCGGTC AGTTCTTTAT GGACCCGAAA CGCATCATTC

121 AAGCCTCCGA CGAAAACACC ATCGGCGTCG TCCCGACTTT CGGCGTGACC TACACCCGTA

181 ACTATCAGTT CCCCCAACCG CTCCACGATG CACTCGATAA ATTCCACGCC GACACCCCTA

241 TCGACATCGA CATCCACATC GACCCTCCCA CCGGTCGCTT CCTCGCACCG TTCGTCGCCC

301 CCGATATCGT CTCCGACTTC CCCCA

>M2_gadARv sequence exported from M2_gadARv_2016-09-15.ab 1 SEQ DNAMAN9: 341 bp; Composition 66 A; 97 C; 94 C; 80 T; 4 OTHER Percentage: $19.4 \% \quad A ; 28.4 \% \quad C ; 27.6 \% \quad$ G; $23.5 \% \quad T ; 1.2 \% O T H E R$

Molecular Weight (kDa): ssDNA: 105.17 dsDNA: 210.25

ORICIN

I GCCGACCCNC CGCTGGCNGC GTCGANGTCC ATCTCGATCT CGATACCGGT GTCCCCCTCO

61 AATTTATCCA GTCCATCGTG CACCGGTTCC GGGAACTCAT AGTTACCGGT GTAGGTCACC

121 CCGAAAGTCG GCACCACGCC GATCGTGTTT TCGTCCCAGG CTTCAATCAT CCGTTTCCGA

181 TCCATAAACA ACTGACCGGG GCGCATAGGG ATCTCGCGCA GCTCCACATC CCAGTACCGA

241 GCGAATTTAT GCCAGCAGAT TTCCACCGGA CCCCACACCA CGTTTCGTTT ATCCGTTCGT

301 TTCCCTGCAC CTTCCATACG CTTNCCAACG CCATTTCATC A

$>$ M3_stx 1Fw sequence exported from M3_stx 1Fw_2016-09-15.ab 1

SEQ DNAMAN9: $128 \mathrm{bp}$; Composition $31 \mathrm{~A} ; 21 \mathrm{C} ; 37 \mathrm{C} ; 33 \mathrm{~T}$; 6 OTHER Percentage: $24.2 \% \quad$ A; $16.4 \% \quad$ C; $28.9 \%$ C; $25.8 \% \quad T ; 4.7 \% O T H E R$

Molecular Weight (kDa): ssDNA: 39.83 dsDNA: 78.91

ORICIN

I CNATAGNNGG ACCTCANCTG NACCCAGNTC TGTCGCAAGA GCGATCTTAC GGTTTGTTAC

61 TCTCACACCT GAACCTTTAC GTTTTCCCCA AATACAGACG CGATTTCGTA GAACACTCCA

121 TCATCTCA

>M3_stx 1Rv sequence exported from M3_stx 1Rv_2016-09-15.ab 1

SEQ DNAMAN 13: 136 bp; Composition 45 A; 29 C; 26 C; 30 T; 6 OTHER Percentage: $33.1 \%$ A; $21.3 \%$ C; $19.1 \%$ C; $22.1 \%$ T; $4.4 \%$ OTHER

Molecular Weight (kDa): ssDNA: 41.99 dsDNA: 83.84

ORICIN

I TTCCNGNAAA NCGTAAACCT TCANCTCNTC ACAGTAACAA ACCCTAACAT CGCTCTTCCC

61 ACAGACTCCO TCAGTCACGT TCCACTATCC GACATTAAAT CCACATAACA ACTACTCAAC

121 GAATCGAACA NTTATA 
>M4_hlyARv sequence exported from M4_hlyARv_2016-09-15.ab 1

SEQ DNAMAN 16: $361 \mathrm{bp}$; Composition 90 A; 89 C; 54 G; $125 \mathrm{~T}$; 3 OTHER Percentage: $24.9 \% \quad A ; 24.7 \% \quad C ; 15.0 \% \quad$ G; $34.6 \% \quad$ T; 0.8\%OTHER

Molecular Weight (kDa): ssDNA: 110.58 dsDNA: 222.52

ORICIN

I AACCTCANTA ATAAGTTCAA TACTACTTTT GCCAATATCA TTNCTCACTT ATATCCTCTC

61 CTTCCCGTTC TTTTCTCACC AATTCATCAA GACCCATCCC TGATAAACCA

ATCCCCGTAA

I21 AATTCTGTAG TCCTCAGACA ACTCTTCCGG CTTTTCCCAG ATTATTACCT

ACATTTTCAC

I8I CCGTTCCTCC TATTTTACTC CCAACTTTCT GATACTTCTC CACAAGTTTC

TCAACTTCTO

241 GTCCGAATAT TCCAACACCA CGTTCAGTTA ATCCTACAAC TTTTTCTCCT

GCACCAAAAA

301 ACTCGTTTCC AATCNCTGTA TCATCTCGTT CAGTACCGTG TATTTCTATT

CCAACCTCAT

$361 \mathrm{C}$

>M6_eaeAFw sequence exported from M6_eaeAFw_2016-09-15.ab 1

SEQ DNAMAN 18: 323 bp; Composition 93 A; 58 C; 62 C; 110 T; O OTHER

Percentage: $28.8 \%$ A; $18.0 \% \quad$ C; 19.2\% C; 34.1\% T; 0.0\%OTHER

Molecular Weight (kDa): ssDNA: 99.7। dsDNA: 199.09

ORICIN

I TTTTTTATGT TAATCAGAAT TCATTTCCAA ATGGTCAAAA TTATTTTAAA TTCGGTTCGG

61 ATTCAAAACT GTTAACTCAT GATACCTATC ACAATCCCCT TTTTTATACG TTCAAAACTC

121 GTCAAACTCT TCCCGATCTT TCTAAATCCC AAGATATTAA TTTATCGACG

ATTTCGTCGT

181 TCAATAAGCA TTTATACAGT TCTGAAAGCG AAATCATGAA GGCCGCGCCT

GGTCACCACA

241 TCATTTTCCC ACTCAAAAAA CTTCCCTTTC AATACAGTCC ACTACCACTT

TTACGTTCCO

301 CACCTCTTGT TCCTCCAGGT GGA

>M6_eaeARv sequence exported from M6_eaeARv_2016-09-15.ab 1

SEQ DNAMAN20: $323 \mathrm{bp}$; Composition $106 \mathrm{~A}$; $62 \mathrm{C}$; $51 \mathrm{C}$; $103 \mathrm{~T}$; 1 OTHER

Percentage: $32.8 \% \quad A ; 19.2 \% \quad C ; 15.8 \% \quad$ C; $31.9 \% \quad T ; 0.3 \% \bigcirc T H E R$

Molecular Weight (kDa): ssDNA: 99.50 dsDNA: 199.08

ORICIN

I TTTTTTCAGT GGCAAAATGA TCTCCTCACC AGCCGCGGCC TTCNTCATTT CGCTTTCACA

61 ACTCTATAAA TCCTTATTCA ACGACCAAAT CGTCGATAAA TTAATATCTT CCGATTTAGA

121 AAGATCGCCA ACAGTTTCAC CAGTTTTCAA CGTATAAAAA AGGCGATTCT

CATACCTATC

181 ATCAGTTAAC AGTTTTCAAT CCGAACCCAA TTTAAAATAA TTTTCACCAT

TTCCAAATCA

241 ATTCTCATTA ACATAAAAAA ACAATCCTAA ACCACCACTA ACCATAATCA ATCTTTTTTT

301 TACCTTATCC TTGTCCCCGG TCA 
>M7_eaeAFw sequence exported from M7_eaeAFw_2016-09-15.ab 1

SEQ DNAMAN22: $322 \mathrm{bp}$; Composition 91 A; $58 \mathrm{C}$; $62 \mathrm{C} ; 108 \mathrm{~T} ; 3$ OTHER Percentage: $28.3 \%$ A; $18.0 \%$ C; $19.3 \%$ C; $33.5 \%$ T; 0.9\%OTHER

Molecular Weight (kDa): ssDNA: 99.40 dsDNA: 198.48

ORICIN

I TTTTTTANGN TANTCAGAAT TCATTTCCAA ATCGTCAAAA TTATTTTAAA TTCGGTTCGC

61 ATTCAAAACT GTTAACTCAT GATACCTATC ACAATCCCCT TTTTTATACG TTCAAAACTC

121 GTCAAACTGT TCCCGATCTT TCTAAATCGC AAGATATTAA TTTATCGACC

ATTTCGTCGT

181 TCAATAACCA TTTATACAGT TCTGAAAGCG AAATGATCAA GCCCGCGCCT

CGTCACCACA

241 TCATTTTCCC ACTCAAAAAA CTTCCCTTTG AATACAGTCC ACTACCACTT

TTACGTTCGC

301 CACCTCTTGT TCCTCCAGGT GC

>M7_eaeARv sequence exported from M7_eaeARv_2016-09-15.ab 1

SEQ DNAMAN24: 324 bp; Composition 109 A; 62 C; 51 G; 101 T; 1 OTHER

Percentage: $33.6 \%$ A; $19.1 \% \quad C ; 15.7 \% \quad$ G; $31.2 \% \quad T ; 0.3 \% O T H E R$

Molecular Weight (kDa): ssDNA: 99.83 dsDNA: 199.70

ORICIN

I TTTTTCAGTG GCAAAATGAT CTCCTCACCA GCCGCGGCCT TCATCATTTC CCTTTCACAA

61 CTGTATAAAT GCTTATTCAA CGACCAAATC GTCGATAAAT TAATATCTTC CGATTTACAA

121 AGATCGGCAA CAGTTTCACC AGTTTTCAAC GTATAAAAAA GGCGATTCTC

ATACCTATCA

181 TCAGTTAACA GTTTTGAATC CGAACCCAAT TTAAAATAAT TTTCACCATT

TCCAAATCAA

241 TTCTCATTAA CATAAAAAAA CAATCCTAAA CCAGCACTAA GCATAATCAA TGTTTTTTTT

301 ACCTNATCCT TGTGCCGGGT CAAA 


\section{ESTUDIO DE LA INTERACCIÓN $\mathrm{BL}-\mathrm{ECEH}$ in vitro}
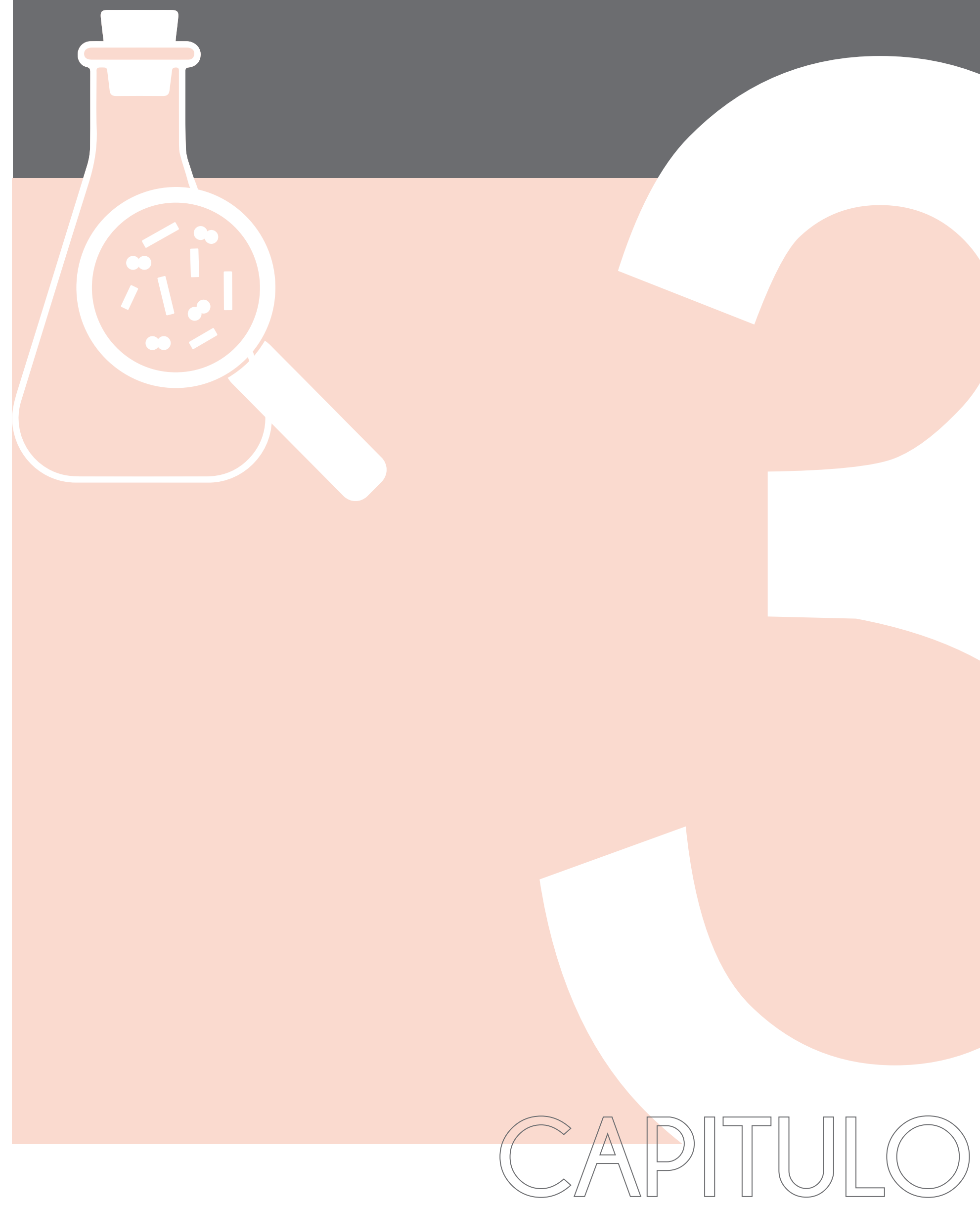


\section{CAPITULO 3 ESTUDIO DE LA INTERACCIÓN BL-ECEH in vitro}

\section{Introducción}

Tras la evaluación de la capacidad antagónica de las cepas lácticas estudiadas frente ECEH, L. plantarum CRL681 y Ent. mundtii CRL35 resultaron los candidatos más eficaces para luchar contra ECEH en el sistema cárnico estudiado. Sin embargo, en este trabajo se decidió seleccionar solo Ent. mundti CRL35 para análisis ulteriores debido a la disponibilidad de su genoma, que se encuentra parcialmente secuenciado y anotado en base de datos, lo cual resultó esencial para la identificación de proteínas durante los estudios proteómicos. Además, esta cepa es capaz de producir la enterocina CRL35, una bacteriocina muy eficaz contra Listeria monocytogenes. De esta forma, Ent. mundtii CRL35 podría ofrecer una potencialidad bioprotectora con un espectro de acción más amplio, es decir, no solo contra ECEH, sino también contra Listeria monocyłogenes, otro patógeno alimentario de gran preocupación para la industria cárnica (Salvucci y col., 2007). Sumado a esto, en nuestro laboratorio se han realizado estudios bioquímicos y genéticos de Ent. mundtii CRL35 que garantizan sus características tecnológicas y bioprotectoras, haciendo de esta cepa una candidata interesante para ser utilizada como cultivo adjunto de alimentos, incluyendo alimentos cárnicos (Saavedra, 2004; Pingitore y col., 2012; Orihuel y col., 2018).

Por todo lo expuesto, en el presente capítulo se buscó profundizar en el conocimiento de los eventos bioquímicos y moleculares que subyacen a la interacción Ent. mundtii CRL35-ECEH, mediante los siguientes estudios:

- Análisis proteómicos de expresión diferencial que permitan comprender el comportamiento y la influencia mutua entre Ent. mundtii y ECEH en ambiente cárnico.

- Estudios de la capacidad de adhesión de ambos microorganismos a proteínas de la matriz extracelular cárnica así como su recíproca influencia sobre este fenómeno.

- Evaluación del potencial de Ent. mundtii CRL35 para inducir la liberación de toxina shiga durante el cocultivo con E. coli C600 4 tox mediante estudios de inducción del fago W933, a fin de conocer el grado de seguridad que presentaría 
la cepa bioprotectora seleccionada durante su coexistencia con el patógeno en el alimento.

- Evaluación de la actividad antilisteria de Ent. mundtii CRL35 durante el cocultivo con ECEH en ambiente cárnico, con el fin de conocer el efecto de la interacción microbiana sobre la producción de enterocina CRL35. La conocida actividad antilisteria, sumada a su acción contra ECEH, le darían al cultivo láctico estudiado un doble interés tecnológico. 


\section{Estudios proteómicos de la interacción BL-ECEH: análisis de expresión diferencial}

\section{Resultados}

Para estudiar las bases moleculares de la acción antagónica de Ent. mundtii hacia ECEH durante su interacción en un ambiente cárnico, se estudió la expresión diferencial de proteínas de ambos microorganismos durante su crecimiento individual o en cocultivo en dos momentos claves de dicha interacción: TI (fase exponencial para ambos microorganismos) y T2 (fase estacionaria para Ent. mundtii y fase de muerte para ECEH) (ver Capítulo 6, Materiales y Métodos). La expresión diferencial de proteínas de cada microorganismo se determinó de acuerdo a las siguientes comparaciones: 1) crecimiento en cocultivo versus crecimiento individual a T I; II) crecimiento en cocultivo versus crecimiento individual a T2 y III) crecimiento en cocultivo a TI versus crecimiento en cocultivo a T2, como se grafica en Figura 3.1.

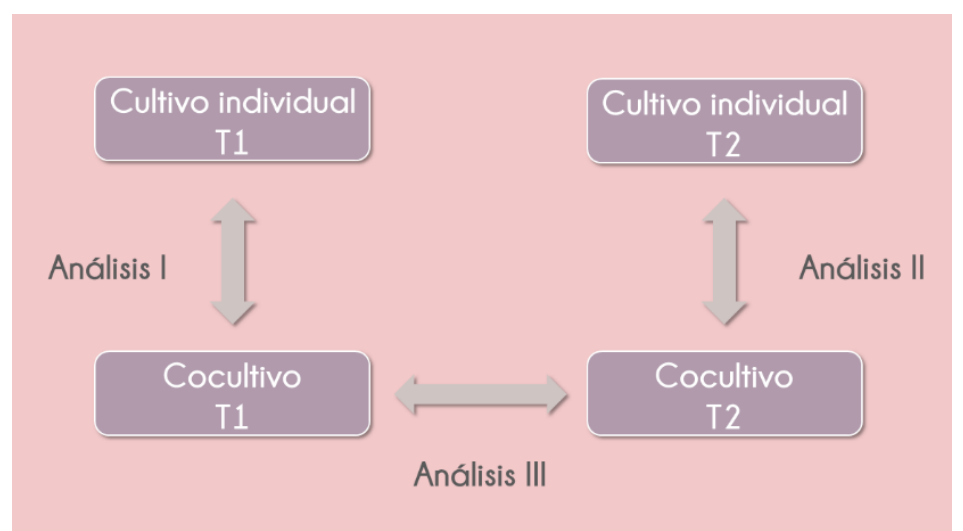

Figura 3.1. Esquema representativo de los diferentes análisis proteómicos abordados. TI corresponde al momento de crecimiento exponencial de ambas cepas (6h) tanto en cocultivo como cultivo individual, T2 corresponde al momento de crecimiento en fase estacionaria de Ent. mundtii en cultivo individual y en cocultivo, y a fase de muerte de ECEH en cultivo individual (96 h) y en cocultivo (30 h).

Los geles 2D obtenidos fueron analizado usando el programa SameSpots, donde se obtuvieron 203 spots que presentaron diferencias significativas en los niveles de expresión ( $p<0,05$ ). De estos 203 spots se seleccionaron 106 que presentaron variaciones de más de 1,5 veces en la expresión ( $p<0,05$, veces de 
expresión (fold change) > 1,5) para su identificación por MALDITOF. Un total de 86 spots fueron identificados con éxito, 45 correspondieron a ECEH y 41 a Ent. mundtii, de acuerdo con las bases de datos consultadas. Las proteínas identificadas se asignaron a diferentes categorías funcionales y además fueron clasificadas de acuerdo a las categorías COC (del inglés Cluster Orthologous Group), que consiste en relacionar a cada proteína con grupos funcionales identificadas con una letra mayúscula, por ejemplo aquellas proteínas relacionadas al metabolismo y transporte de aminoácidos se representan con la letra E.

De forma mostrativa, en la Figura 3.2, se exponen los mapas 2D obtenidos luego de realizar los 3 análisis comparativos. Para cada análisis se encuentran marcadas las proteínas expresadas diferencialmente (de ambos microorganismos) y enumeradas aquellas pertenecientes a Ent. mundtii.

\section{Discusión}

La interacción y las actividades antagónicas de BL con diferentes microorganismos patógenos fueron el foco de numerosos estudios. Entre ellos, Atassi y Servin (2010) investigaron la capacidad de cepas de Lactobacillus para combatir Salmonella entérica serovar Typhimurium en cocultivos; Angmo y col. (2016) evaluaron diferentes cepas de BL como agentes de biocontrol contra Yersinia enterocolitica usando ensayos de inhibición en placa como método de detección, para luego evaluar el crecimiento del patógeno en cultivos mixtos con dos cepas de Lactobacillus seleccionadas. Por otro lado, Yang y col. (2017) estudiaron cultivos mixtos de bifidobacterias con Listeria monocytogenes para detectar cambios en su patrón de crecimiento luego de la interacción mediante la aplicación de un enfoque proteómico. El presente estudio es el primero donde se evalúa el potencial inhibidor de cepas de BL frente a ECEH en cocultivos utilizando enfoques tanto fisiológicos como proteómicos. Si bien los estudios fisiológicos realizados mostraron un efecto inhibitorio de Ent. mundtii sobre ECEH en SCM, el enfoque proteómico abordado nos permitió profundizar en las bases moleculares de la interacción entre ambos microorganismos y su relación con los eventos fisiológicos observados durante su desarrollo conjunto en SCM. 

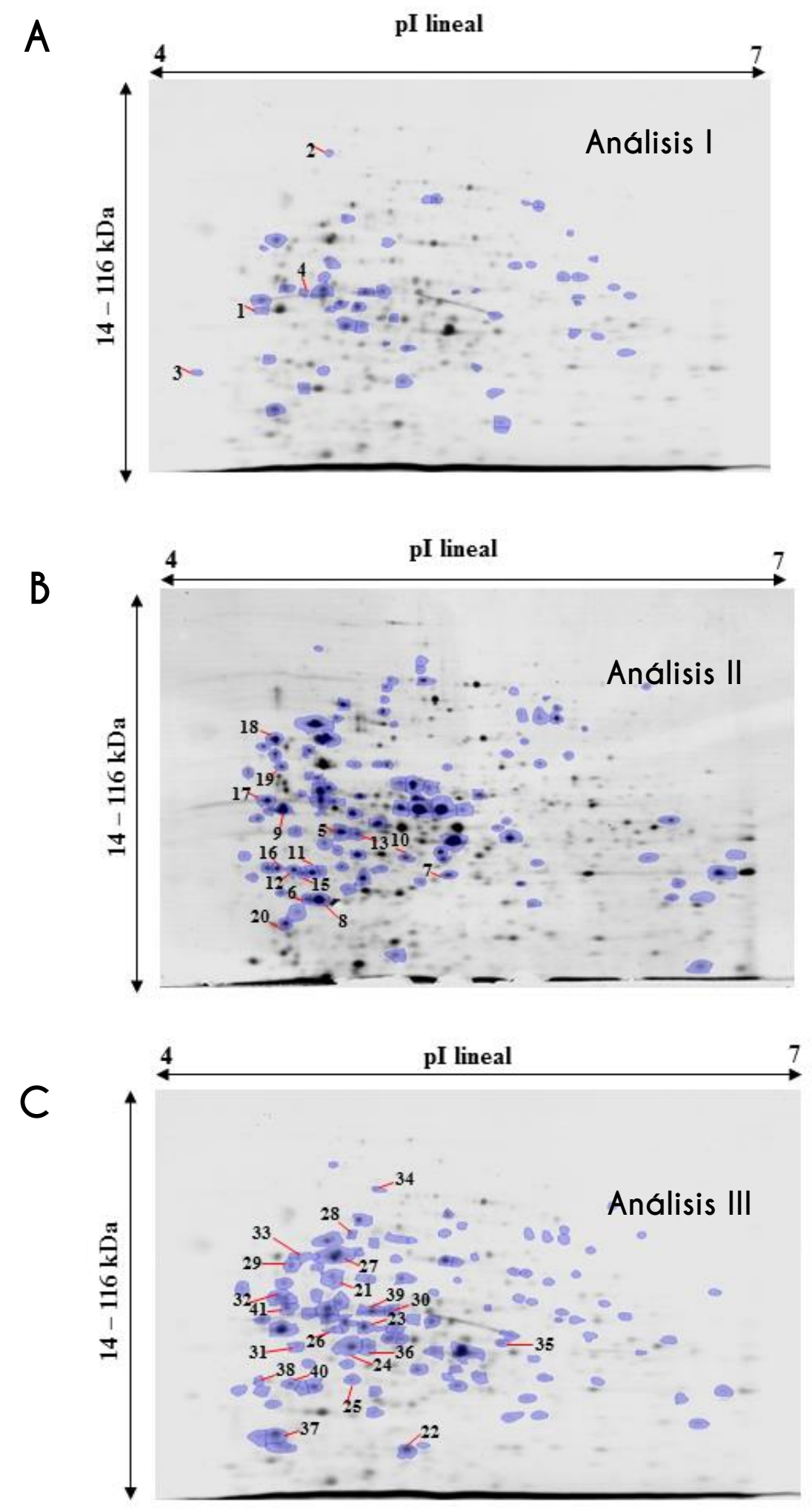

Figura 3.2. Geles E2D mostrando las proteinas diferencialmente expresadas de ambos microorganismos. Las proteínas identificadas exitosamente de Ent. mundtii se encuentran enumeradas. (A) Cocultivo T1 versus Cultivo Individual TI, (B) Cocultivo T2 versus Cultivo Individual T2, (C) Cocultivo T1 versus cocultivo T2. 


\section{A. Análisis proteómico para Ent. mundtii CRL35 durante su crecimiento en SCM}

\section{Resultados}

Expresión diferencial de proteínas de Ent. mundtii CRL35 creciendo en cocultivo con respecto a su crecimiento individual

Cuando se comparó los proteomas del crecimiento en cocultivo con respecto al crecimiento individual en SCM, se obtuvo una sobreexpresión significativa de proteínas de Ent. mundtii en cocultivo en ambos tiempos analizados (TI y T2). Las proteínas identificadas se asignaron con éxito a diferentes categorías funcionales. Especificamente, a TI resultaron sobreexpresadas 4 proteínas por Ent. mundtii en cocultivo (Tabla 3.2, Figura 3.3A), las cuales estuvieron relacionadas con:

- Metabolismo de aminoácidos (50\%),

- Metabolismo de carbohidratos (25\%),

- División celular (25\%),

Por otro lado, a T2, cuando Ent. mundtii alcanzó su fase estacionaria de crecimiento en ambas condiciones, 16 proteínas identificadas resultaron sobreexpresadas en cocultivo con una diferencia significativa entre 2, 1 y 4,7 veces con respecto al cultivo individual (Tabla 3.2; Figura 3.3B). Estas proteínas se relacionaron con:

- Metabolismo de carbohidratos (31,25\%),

- Conversión y producción de energía (18,75\%),

- Transcripción (6,25\%),

- División celular (6,25\%),

- Biosíntesis de la pared celular (6,25\%),

- Metabolismo de aminoácidos (6.25\%),

- Plegamiento y procesamiento proteico (6.25\%),

- Estructura ribosomal (6.25\%)

- Estrés (6.25\%)

Además, se realizó un análisis de distribución hipergeométrica, el cual permite determinar la probabilidad que una determinada categoría COO se encuentre enriquecida en la muestra de proteínas sobreexpresadas en nuestro estudio, en relación a la totalidad de proteínas codificadas por el genoma de la célula. Los resultados de este análisis indicaron que, en una muestra de 16 proteínas sobreexpresadas, existe más probabilidad de encontrar solo una relacionada con 
el metabolismo y el transporte de carbohidratos (E) (Figura 3.4), sin embargo en nuestro estudio se encontraron cinco de ellas expresadas diferencialmente a T2 (Tabla 3.2), indicando que esta categoría se encuentra enriquecida en las condiciones analizadas. Esto también ocurrió con las categorías de conversión y producción de energía ( $\mathrm{C}$ ), plegamiento y procesamiento de proteínas ( $\mathrm{O}$ ) y biosíntesis de la pared celular (M). Para las proteínas relacionadas con transcripción $(K)$, estrés (S), estructura ribosomal (J) y metabolismo de aminoácidos (E) se encontró una proteína sobreexpresada de cada categoría como se esperaba según la distribución hipergeométrica. Sin embargo, para la oxidoreductasa que incluye tres categorías de COC $(\mathrm{I}, \mathrm{Q}, \mathrm{R})$, era más probable encontrar dos proteínas y solo se identificó una proteína sobreexpresada, lo que podría implicar un empobrecimiento de estas categorias (Figura 3.4A, Tabla 3.2).

Expresión diferencial de proteínas de Ent. mundtii CRL35 al comparar su crecimiento en cocultivo en ambos tiempos analizados ( $T 1$ y T2)

Durante el crecimiento en cocultivo, Ent. mundtii expresó diferencialmente (entre 1,5 y 3,4 veces) 21 proteínas. Veinte de ellas presentaron sobreexpresión a las $6 \mathrm{~h}$ de crecimiento en cocultivo ( $(\mathrm{I})$ y solo una de ellas, la fosfoglucomutasa/fosfomanomutasa, se expresó mayoritariamente a las 30 h durante el cocultivo (T2) (Tabla 3.3, Figura 3.3). Las proteínas sobreexpresadas pudieron ser clasificadas y se demostró que pertenecen a diferentes categorías funcionales, a saber:

- Metabolismo de carbohidratos (40\%),

- Metabolismo de aminoácidos (15\%),

- Producción y conversión de energía (20\%),

- Transcripción (5\%),

- Metabolismo de nucleótidos (5\%),

- Traducción (5\%),

- Estrés (5\%),

- Biosíntesis de la pared celular (5\%)

Además, al realizar el análisis de distribución hipergeométrica, se demostró que las categorías relacionadas con metabolismo de carbohidratos ( $G$ ), producción y conversión de energía (C), transporte y metabolismo de aminoácidos (E), transporte y metabolismo de nucleótidos (F) están enriquecidas, mientras que las categorías de 
traducción (J), transcripción (K), biogénesis de la pared celular (M) y de función desconocida (S) no presentaron variaciones (Figura 3.4B).

En los tres análisis proteómicos realizados, el mayor número de proteínas expresadas diferencialmente se relacionó con las categorías funcionales de metabolismo de carbohidratos, producción de energía y metabolismo de aminoácidos (Figura 3.3).

A

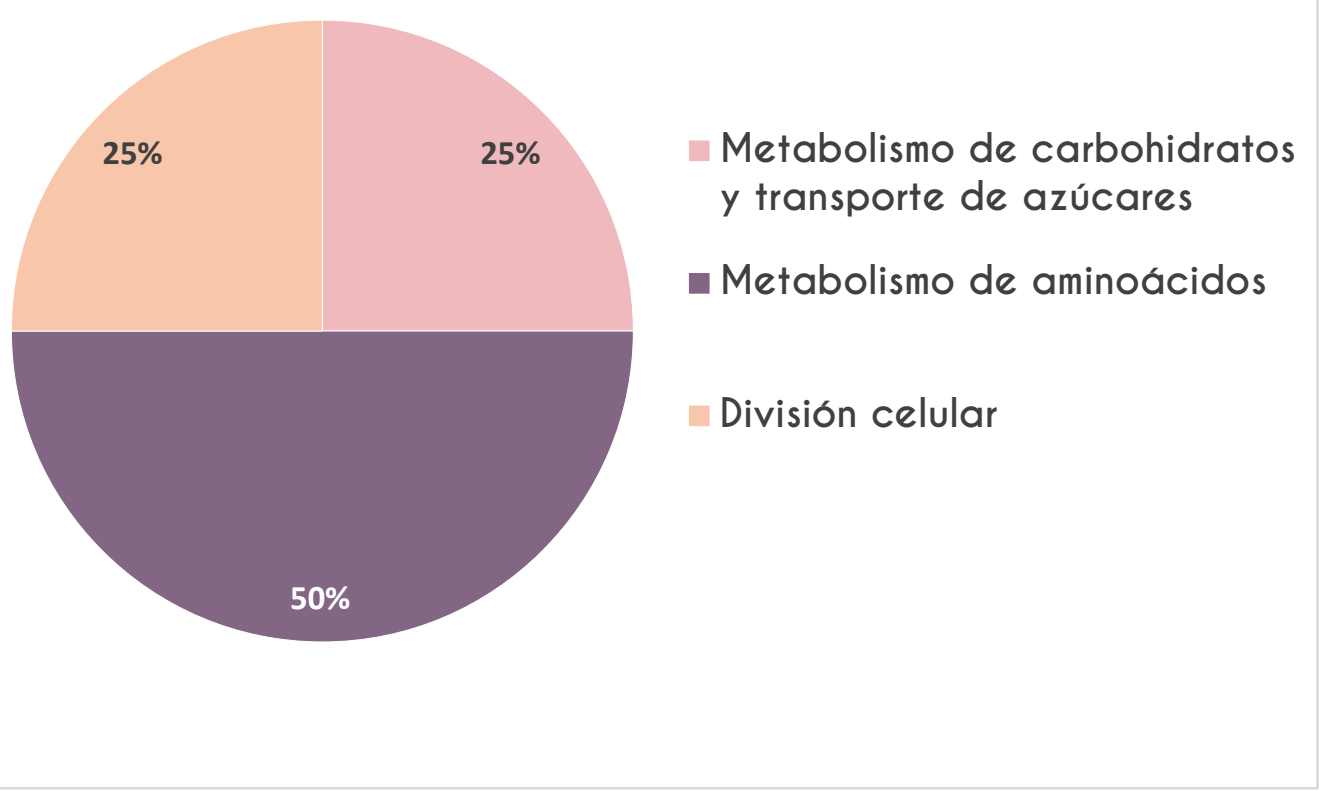


B

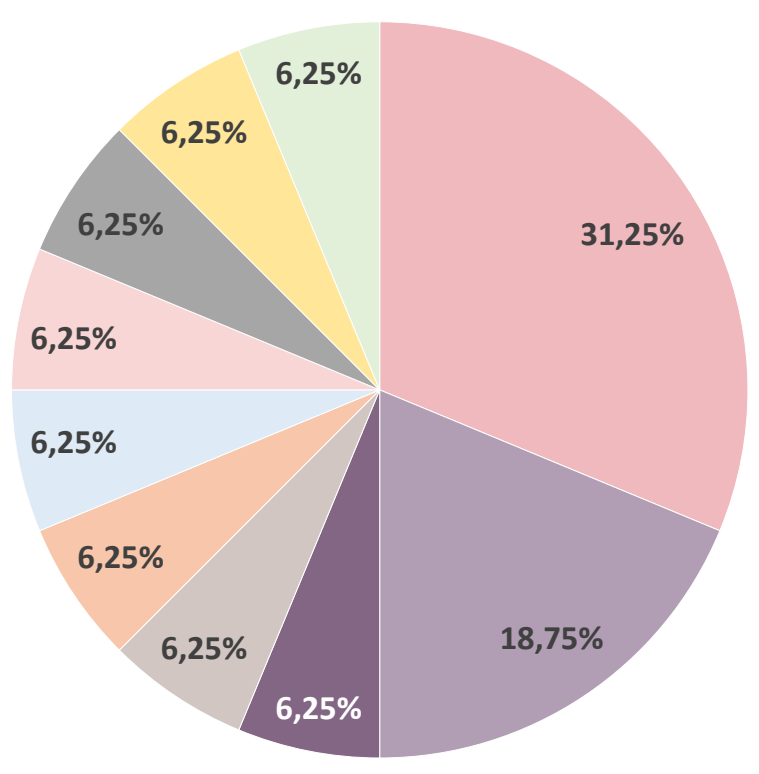

Metabolismo de carbohidratos y transporte de azúcares Producción y conversión de energía - Metabolismo de aminoácidos

- Transcripción

División celular

Biosíntesis de la pared celular

Plegamiento y procesamiento proteico

- Estrés

Metabolismo

Estructura Ribosomal

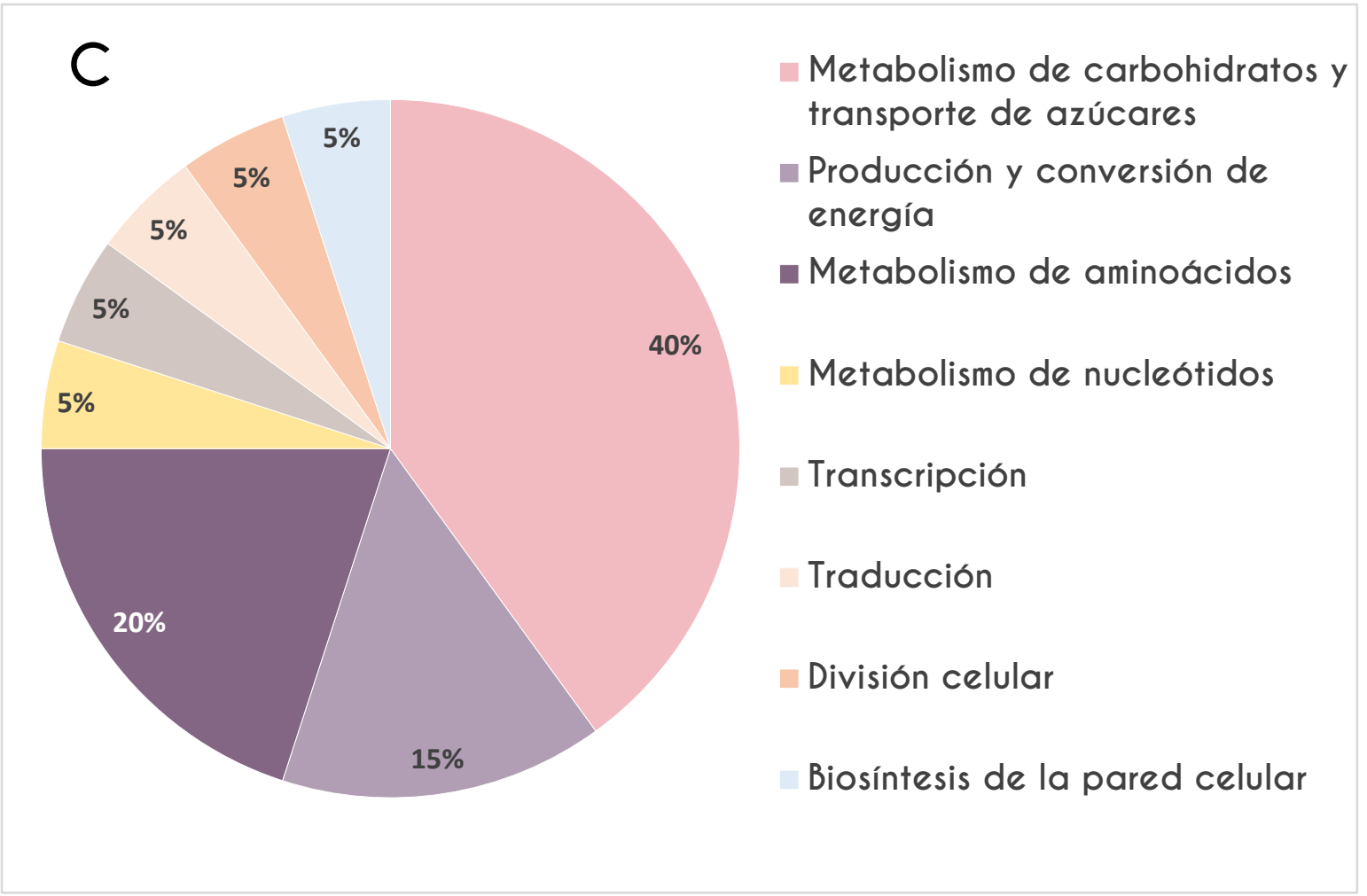

Figura 3.3. Abundancia relativa (\%) de las proteínas sobreexpresadas por Ent. mundtii CRL35 según las categorías funcionales a las cuales pertenecen. (A) Cocultivo TIversus crecimiento individual TI; (B) Cocultivo T2 versus crecimiento individual T2; (C) Cocultivo T1 versus cocultivo T2. 
A

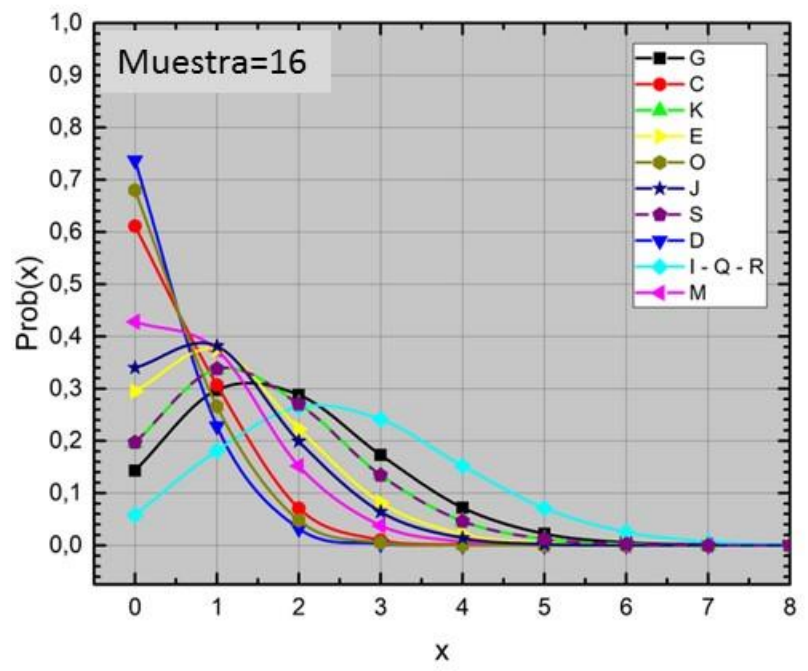

B

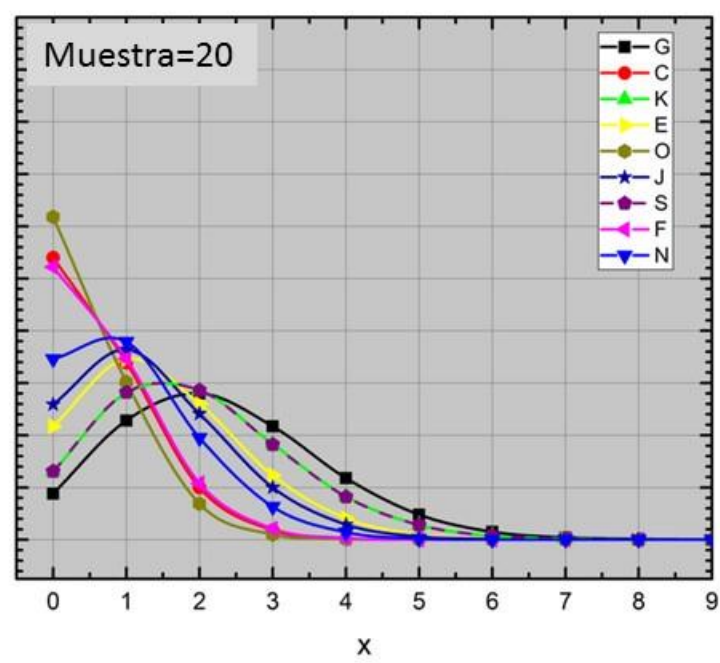

Figura 3.4. Análisis hipergeométrico según el cual se grafica la distribución de las probabilidades (Prob) de encontrar una determinada categoría funcional COC un cierto número de veces "x" en relación al número total de proteínas codificadas por el genoma de la cepa. (A) 16 proteínas sobreexpresadas de Ent. mundtii CRL35 (Muestra=16) cuando crece en cocultivo frente a cultivo individual a T2 y (B) 20 proteínas sobreexpresadas de Ent. mundtii CRL35 (Muestra=20) cuando crece en cocultivo en T1 frente a T2. Abreviaturas de una letra para las categorías funcionales COG: C: metabolismo y transporte de carbohidratos; C: producción y conversión de energía; K: transcripción; D: división celular y partición cromosómica; I: metabolismo lipídico; Q: biosíntesis, transporte y catabolismo de metabolitos secundarios; R: solo predicción funcional general; M: biosíntesis de la pared celular; E: transporte y metabolismo de aminoácidos; $O$ : plegamiento y procesamiento proteico; J: traducción, incluyendo estructura de ribosomas y biogénesis; S: sin predicción funcional, N: motilidad. 
Análisis funcional e interacción de proteínas expresadas diferencialmente por Ent. mundtii CRL35

Si bien las proteínas identificadas fueron clasificadas según diferentes categorías funcionales, es necesario conocer si la función biológica específica de cada una de ellas las relaciona de manera concreta, y a partir de allí inferir acerca de la estimulación o inhibición de un evento, proceso o metabolismo dado. En este sentido la utilización de bases de datos como STRING v10.05 resultan una herramienta de gran valor ya que permite la construcción de redes de interacción proteína-proteína basándose en la combinación de diferentes criterios (interacciones determinadas experimentalmente, interacciones predichas mediante genes vecinos, fusión de genes, coexpresión, etc), a partir de los cuales genera un puntaje que permite establecer distintos niveles de interacción entre las proteínas de la red.

Además, el hallazgo de interacciones mediante esta base de datos, respalda la coexpresión diferencial del conjunto de proteínas obtenidas en nuestros análisis, y contribuye a establecer el significado biológico sobre ellas.

Se construyeron dos redes de interacción para aquellas proteínas expresadas diferencialmente por Ent. mundtii: i) proteínas sobreexpresadas por Ent. mundtii en cocultivo con respecto a su crecimiento individual a T2 (Figura 3.5A); no se construyó una red para TI ya que solo cuatro proteínas resultaron sobreexpresadas en esta condición, y ii) proteínas de Ent. mundtii sobreexpresadas en T1 con respecto a T2 en cocultivo con ECEH (Figura 3.6A). En dichas redes, cada proteína se encuentra representada mediante nodos y la fuerza de las interacciones entre ellas está representada por el grosor de las líneas que las une. En círculo se destacan las interacciones de mayor intensidad observadas entre las proteínas de las diferentes redes.

Los resultados arrojados por STRING, fueron lvego objeto de análisis de una nueva base de datos, análisis y visualización, Cytoscape v3.6.1, mediante la cual se obtuvieron redes de mayor complejidad (Figura 3.5B y Figura 3.6B), en las cuales, además de representarse la intensidad de la interacción mediante el grosor de las líneas de unión, el tamaño de los nodos refleja las veces de expresión de cada proteína en las condiciones estudiadas.

Como se muestra en la Figura 3.5A, 5 de las 15 proteínas sobreexpresadas en cocultivo a T2 con respecto al cultivo individual no tienen interacciones entre sí. Sin embargo, 10 proteínas estaban relacionadas demostrando que existían 
interacciones entre ellas. Cuatro proteínas están relacionadas con el metabolismo de carbohidratos y tres de ellas con la producción y conversión de energía, mostrando interacciones muy fuertes entre sí. Esto también respalda el hecho de que el metabolismo de carbohidratos (G) a través de la glucólisis se encontró enriquecido lvego del análisis hipergeométrico a T2 durante el cocultivo con ECEH. Los niveles de sobrexpresión de cada proteína de este grupo se presentó en un amplio rango, registrándose valores entre 2 y 4,7 veces de expresión en cocultivo con respecto al cultivo individual a T2, siendo 6-fosfofructokinasa (pfkA), Llactatodeshidrogenasa (ldh) y 2-oxoisovalerato deshidrogenasa subunidad beta (AK 89_08915), aquellas que evidenciaron mayor diferencia de expresión, (5,32, 4,74 y 4,70 respectivamente) (Figura 3.5B).

La segunda red (Figura 3.6) corresponde a las proteínas sobreexpresadas por Ent. mundtii creciendo en cocultivo a las 6 h respecto a las 30 h, (TI versus T2). Dos (Proteína de estrés general, familia Asp23/Cls24 y Colilglicinahidrolasa) de las 20 proteínas no presentaron interacciones en la base de datos consultada. Además, 3 proteínas presentaron interacciones entre sí, sin observarse relaciones con las proteínas restantes. En esta red se obtuvieron sesenta y ocho interacciones entre las proteínas sobreexpresadas por Ent. mundtii. Como se mencionó anteriormente, la sobreexpresión de estas 20 proteínas en el cocultivo a T1 con respecto a T2 podría explicarse por la fase de crecimiento logarítmico de Ent. mundtii a las $6 \mathrm{~h}$. Además, como se puede observar en la Figura 3.6A, las principales interacciones encontradas en la red están relacionadas con el metabolismo de los hidratos de carbono (7 proteínas), implicados en particular en la vía de la glucólisis y de la pentosa fosfato. Esta red de interacción respalda además el enriquecimiento de la categoría $C$ evidenciado por la prueba de distribución hipergeométrica descripta anteriormente. Por otro lado, a través de la red presentada en la Figura 3.6B, se puede observar cierta uniformidad en el tamaño de los nodos, lo cual indica similares niveles de sobreexpresión entre las proteínas de este grupo, estando éstos valores comprendidos entre 1,5 y 3,4 veces de expresión a T1 con respecto a T2 en cocultivo con ECEH. 
A

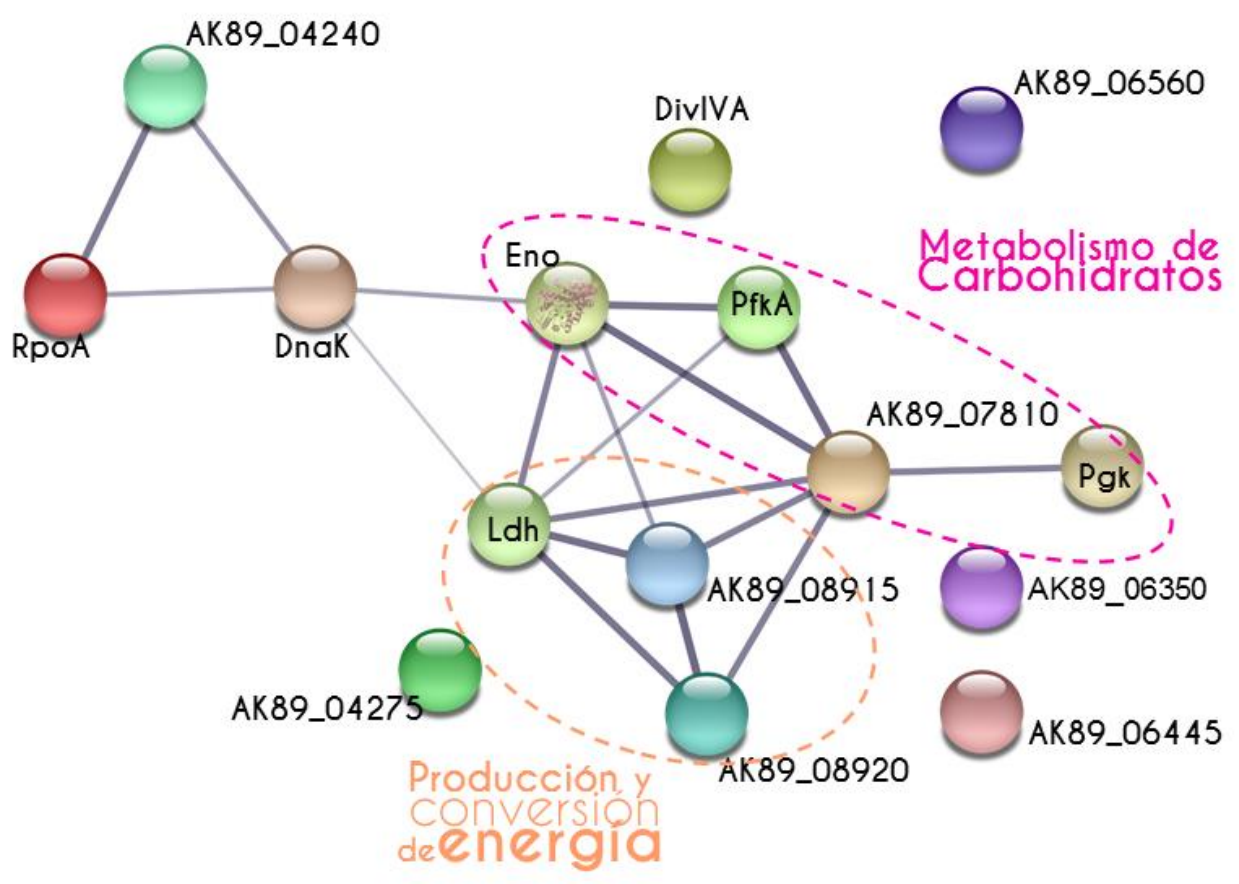

B

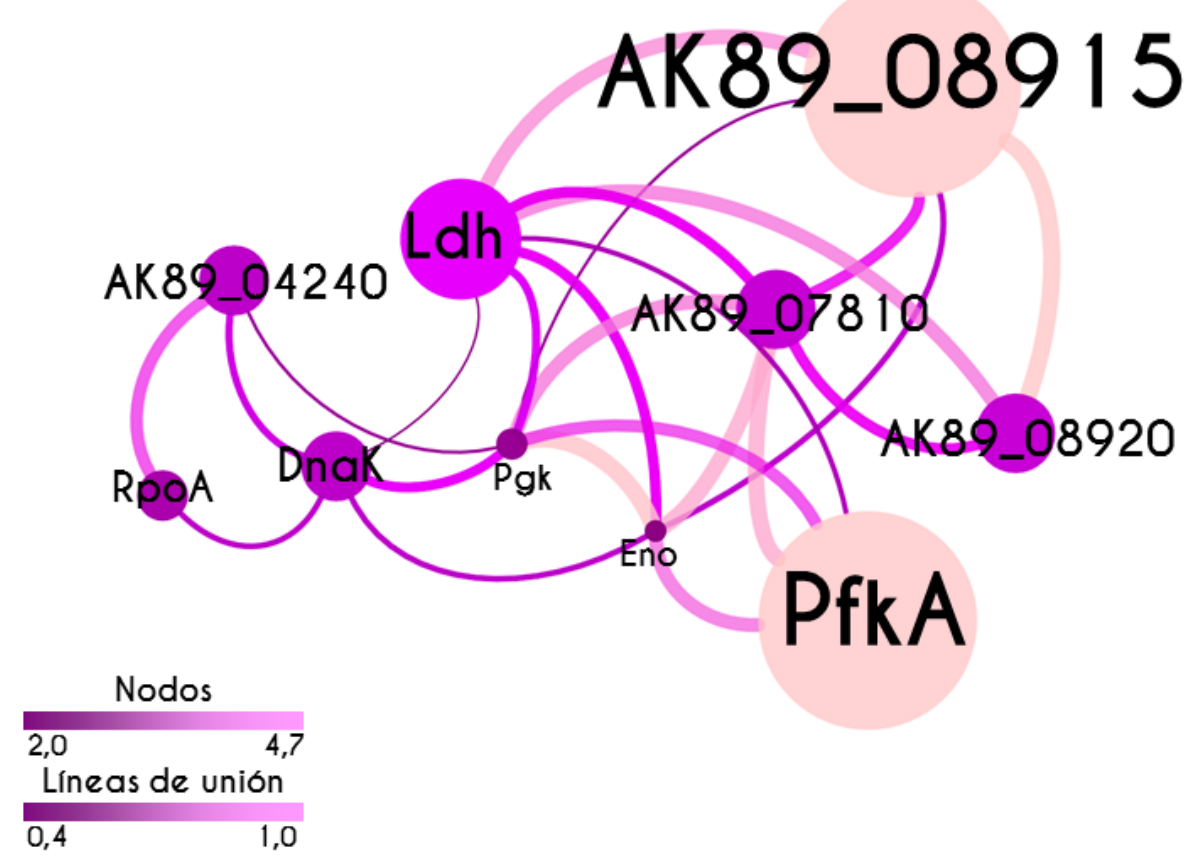

Figura 3.5. Red de interacción de proteínas sobreexpresadas por Ent. mundtii CRL35 en cocultivo con respecto a su cultivo individual a T2. Las proteínas están representadas por nodos mientras que sus interacciones por líneas. La fuerza de las diferentes interacciones está representada por el grosor de las líneas. (A) Red construida utilizando STRING v10.05. Los círculos agrupan las proteínas relacionadas con el metabolismo de los carbohidratos y la producción y conversión de energía respectivamente. (B) Red construida utilizando Cytoscape v3.6. I. El tamaño de los nodos representa de forma proporcional las veces de expresión de cada proteína representada. La gama de colores en líneas de unión y nodos indican la magnitud de la interacción y veces de expresión respectivamente, siendo los mayores valores representados en color rosado y los menores en color violeta. 
A

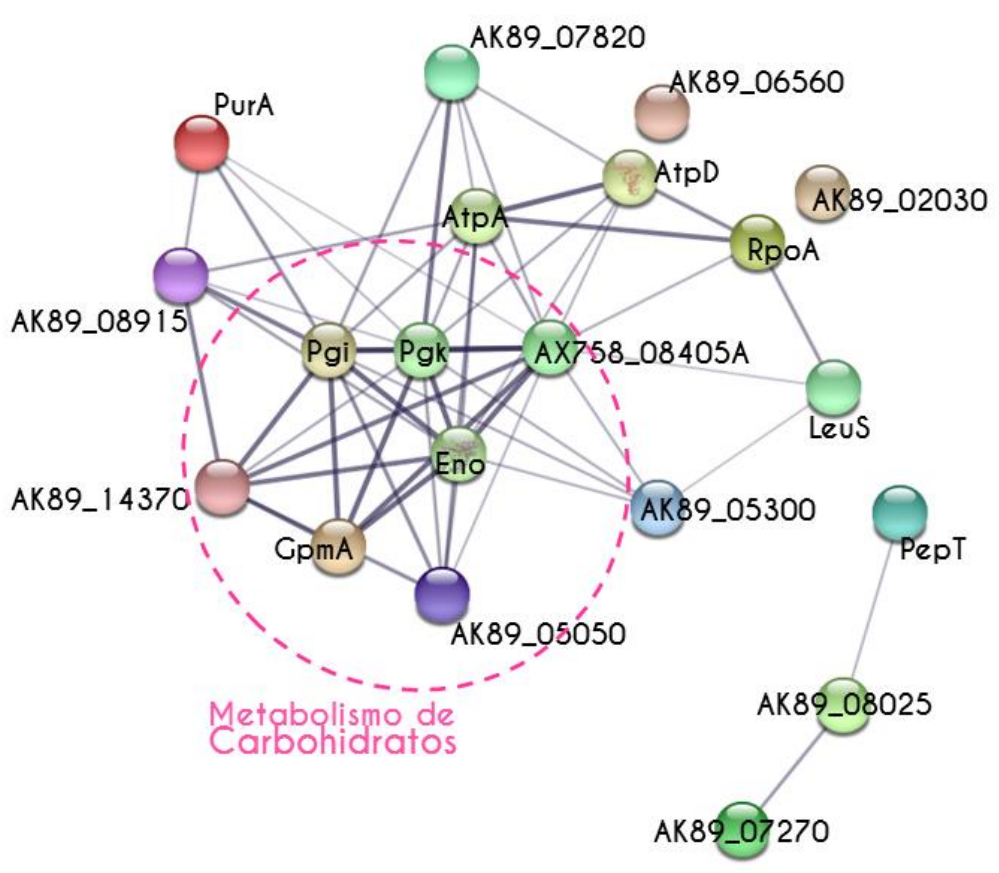

B

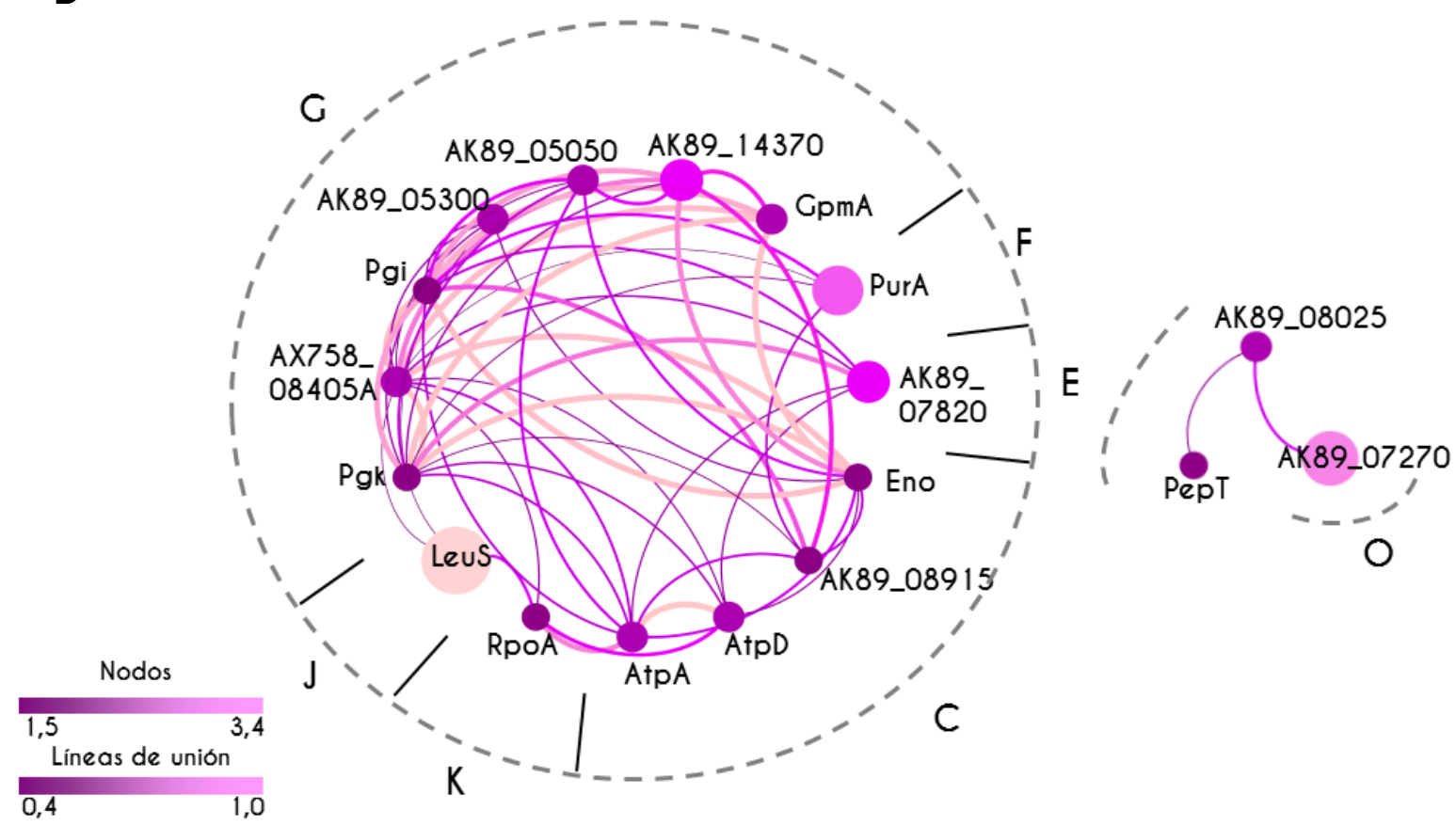

Figura 3.6. Red de interacción de proteínas sobreexpresadas por Ent. mundtii CRL35 en cocultivo a T1 con respecto a T2. Las proteínas están representadas por nodos mientras que sus interacciones por líneas. La fuerza de las diferentes interacciones está representada por el grosor de las lineas. (A) Red construida utilizando STRINC v10.05. El círculo agrupa las proteínas relacionadas con el metabolismo de los carbohidratos. (B) Red construida utilizando Cytoscape v3.6.1. El tamaño de los nodos representa de forma proporcional las veces de expresión de cada proteína representada. El orden de los nodos en la representación circular está dada por la categoría COC a la cual pertenecen. La gama de colores de las líneas de unión y nodos indican la magnitud de la interacción y veces de expresión respectivamente, siendo los mayores valores representados en color rosado y los menores en color violeta. Abreviaturas de una letra para las categorías funcionales COG: C: metabolismo y transporte de carbohidratos; C: producción y conversión de energía; K: transcripción; E: transporte y metabolismo de aminoácidos; F: metabolismo de nucleótidos; O: chaperonas moleculares y funciones relacionadas; J: traducción, incluyendo estructura de ribosomas y biogénesis. 


\section{Discusión}

Cuando se comparó la expresión de proteínas de Ent. mundtii CRL35 en cocultivo con la ocurrida durante su crecimiento como cultivo individual, la proteínas identificadas se encontraron siempre sobreexpresadas durante el crecimiento en cocultivo, tanto a T1 como a T2. Sin embargo, las variaciones del proteoma a T1 fueron ligeras. Un transportador ABC para metionina y la subunidad mayor de carbamoil fosfato sintasa están entre las proteínas sobreexpresadas. Ambas relacionadas con la biosíntesis y metabolismo de aminoácidos. Una enzima relacionada con la glucólisis, la enolasa (spot $N^{\circ}$ 9) y una enzima implicada en la división celular, proteína FtsZ, (spot $N^{\circ} 14$ ) resultaron sobreexpresadas también en cocultivo durante estas primeras horas de crecimiento, lo que indicaría que Ent. mundtii activó su vía glicolítica y el proceso de división celular para competir con ECEH y mantener su crecimiento sin abruptos cambios. Cabe mencionar que la enolasa también se conoce como proteína de pluriempleo, conocidas en inglés como moonlighting proteins. Estas son proteínas que muestran funciones adicionales, distintas de su principal actividad catalítica descripta. En general, estas proteínas citoplásmicas pueden ser de superficie celular durante sus actividades adicionales y desempeñan funciones en infecciones, virulencia o respuestas inmunes (Jeffery, 2015). Por ejemplo, la enolasa también se asocia con la unión a células epiteliales (Castaldo y col., 2009). De hecho, Peng y col. (2014) describieron a la enolasa como una de las proteínas de unión a actina en Enterococcus faecalis. Por lo tanto, se podría sugerir que Ent. mundtii podría regular la expresión de esta proteína durante el cocultivo con ECEH como una estrategia adicional para competir con el patógeno por la unión a actina durante el proceso de adhesión a la matriz cárnica. Por otro lado, el proteoma de Ent. mundtii se vio mucho más afectado en el cocultivo a las 30 h que en su respectivo crecimiento individual.

La red de interacción proteína-proteína, construida con las proteínas sobreexpresadas a las 30 h, mostró clara interacción en doce de estas proteínas, relacionadas principalmente con el metabolismo de carbohidratos. El 31,25\% de las proteínas con sobreexpresión diferencial estuvieron involucradas en la glucólisis, y el 18,75\% en la producción y conversión de energía, lo que indicaría que el cocultivo con ECEH ejerció una activación más efectiva de estas vías en su fase estacionaria (T2). Además, los resultados fisiológicos indicaron que a las 30 h, ECEH se encuentra en fase de muerte en cocultivo, lo que sugiere también, que la disminución de viabilidad de ECEH resultó en beneficio para Ent. mundtii que persistió en fase estacionaria. Más aún, Ent. mundtii, resultó incluso más estable en su fase estacionaria 
durante el cocultivo que en su crecimiento individual. Este hecho es consistente con la sobreexpresión de muchas proteínas del metabolismo de carbohidratos, la producción de energía, la transcripción, la división celular y el metabolismo de aminoácidos que reflejan un metabolismo activo de Ent. mundtii permitiéndole su persistencia en SCM. También se debe resaltar la regulación positiva de las proteínas relacionadas con el plegamiento/procesamiento proteico y el estrés, como la chaperona Dnak y el regulador de respuesta a estrés Cls24, que podrían contribuir a la resistencia satisfactoria de Ent. mundtii a condiciones estresantes que dominan el ambiente microbiano en esta fase del crecimiento (T2), como por ejemplo la disminución de nutrientes o el descenso de $\mathrm{pH}$ registrado (pH: 4,0). Existen algunos estudios que demuestran la interacción de ciertos microorganismos durante su crecimiento en cultivos mixtos. Yang y col. (2017) propusieron que el crecimiento de Bifidobacterium bifidum UBBIO3 y Listeria monocytogenes en cocultivo promueve el crecimiento de forma recíproca, lo que resulta en la entrada más temprana a fase logarítmica. Por su parte, Rios-Covián y col. (2016) describieron la estimulación del crecimiento de Bifidobacterium longum en cocultivo con Bacteroides fragilis mientras se retardó el crecimiento de éste último, con cambios concomitantes en la producción de algunas proteínas y metabolitos de ambas bacterias. En el presente trabajo parece ocurrir una interacción diferente entre Ent. mundtii y E. coli NCTC 12900. De hecho, pareciera producirse un efecto positivo de ECEH sobre la aptitud de la bacteria láctica, mientras que ésta fue capaz de precipitar la muerte del patógeno en cocultivo en las condiciones ensayadas.

Al comparar el proteoma de los cocultivos a lo largo del tiempo (T1 y T2), resultaron sobreexpresadas veinte proteínas de Ent. mundtii durante las primeras horas de crecimiento. Esto está relacionado con la fase de crecimiento exponencial que atraviesa el microorganismo, en donde el metabolismo general se encuentra activado como esperábamos y según lo documentado por estudios previos (Cohen y col., 2006; Koistinen y col., 2007). Esos resultados también fueron respaldados al construir la red de interacción de proteínas (Figura 3.5), donde aquellas relacionadas con el metabolismo de carbohidratos presentaron interacciones de mayor magnitud. Entre las proteínas reguladas, se identificaron 7 pertenecientes al metabolismo de carbohidratos y 1 al transporte de azúcares. Cinco enzimas se relacionaron con la glucólisis (spots $N^{0} 22,23,24,25$ y 27) y dos estuvieron involucradas en la ruta de la pentosa fosfato ( ppots $\mathrm{N}^{\circ} 26$ y 28) (Figura 3.11). La sobreexpresión de fosfoenolpiruvato fosfotransferasa, implicada en el transporte de carbohidratos, podría facilitar la entrada de glucosa en la célula, reflejando una 
ventaja para la incorporación de azúcar, contribuyendo así a su lucha contra la presencia del patógeno que también se encuentra en estado de crecimiento logarítmico. Solo una enzima glicolítica, la fosfoglucomutasa (spot $N^{\circ} 21$ ), se expresó en menor cantidad a las $6 \mathrm{~h}$. Esto podría relacionarse con la regulación en alza del PTS fosfoenolpiruvato fosfotransferasa (sistema PTS) involucrado en el transporte de glucosa mediante la generación de glucosa-6P, la cual ingresa directamente en la ruta Embden-Meyerhorff-Parnas, lo que explicaría la baja expresión de fosfoglucomutasa productora de glucosa-6P a partir de glucosa- IP procedente de otras vías, como la de hidrólisis del glucógeno (Bonacina, 2017) (Figura 3.11). El metabolismo del glucógeno sería menos activo que el de glucosa durante las primeras horas. De hecho, la glucosa está disponible, ya que se adiciona al sistema cárnico modelo, por lo que estaría siendo utilizada por Ent. mundtii como fuente de energía primaria en las primeras horas de cultivo. Por otro lado, dos enzimas relacionadas con la vía de la pentosa fosfato / fosfocetolasa (PKP) resultaron sobreexpresadas en Ent. mundtii a Tl, la gluconato deshidrogenasa 6-P y la transcetolasa, indicativas también del metabolismo activo de la ribosa, uno de los azúcares presentes en la carne (Chaillou y col., 2005) (Figura 3. 1 1). De acuerdo con nuestros hallazgos, Koistinen y col. (2007) informaron que las principales proteínas expresadas por L. plantarum en fase exponencial temprana estaban relacionadas con el consumo de azúcar y el aumento de la biomasa.

Cuatro enzimas relacionadas con el metabolismo de aminoácidos también fueron sobreexpresadas por Ent. mundtii en cocultivo a T1 con respecto a T2. Entre ellas, la glutamina sintasa, enzima clave del metabolismo del nitrógeno que cataliza la incorporación de amonio en el glutamato y está relacionada con la biosíntesis de arginina, alanina, glutamato y el metabolismo del aspartato, entre otros (Magasanik y Rothstein, 2012). Además, algunas otras peptidasas y aminopeptidasas resultaron sobreexpresadas también a T1, lo que indica un metabolismo peptidolítico activo durante las primeras horas de cocultivo. Por otra parte, se observa que la sobreexpresión de adenilsuccinato sintasa fue de 2.7 veces. Esta enzima juega un papel importante en la biosíntesis de novo de nucleótidos de purina, catalizando el primer paso comprometido en la biosíntesis de AMP a partir de IMP, lo cual indica también un metabolismo más activo durante las primeras horas de cocultivo. Las proteínas implicadas en la transcripción y la traducción, tales como la subunidad alfa de ARN polimerasa dirigida por ADN y ligasa de leucina-ARNt resultaron también sobreexpresadas durante las primeras horas de cocultivo. En apoyo a esto, Yang y col. (2017), informaron la regulación positiva de las enzimas relacionadas con la 
transcripción y la traducción cuando se evaluaron cultivos mixtos de Bifidobaterium bifidum y Listeria monocytogenes.

Una proteína de estrés general (proteína de estrés general familia Asp23/Cls24) presentó también mayor expresión en T1, así como la colilglicinahidrolasa implicada en el metabolismo lipídico y la biosíntesis de la pared celular. Este patrón se puede relacionar con el crecimiento exponencial y la consecuente división celular. Dos ATP sintasas (subunidades alfa y beta) se encontraron aumentadas en esta condición. Estas enzimas son los principales productores de ATP, utilizando el gradiente de protones generado por la fosforilación oxidativa. Finalmente, la subunidad beta de la 2-oxoisovalerato deshidrogenasa fue sobreexpresada 1,9 veces a TI durante el cocultivo. Esta enzima pertenece a la familia de las oxidoreductasas, que también está implicada en la degradación de Phe, Tyr, Trp, Leu, lle, Val, Asp y Asn.

De acuerdo con los resultados obtenidos, se puede postular el efecto positivo de ECEH en la aptitud de la cepa láctica para crecer e inhibir a ECEH durante el cocultivo, mientras que se evidenció un impacto negativo de Ent. mundtii sobre el patógeno al precipitar su muerte después de 8 h de cocultivo.

Sin bien con estos estudios no se puede confirmar exactamente los mecanismos moleculares implicados en la inhibición llevada a cabo por la BL sobre ECEH, se sugiere que fenómenos como la competencia por nutrientes y la relación célula-célula contribuirían a los fenómenos observados de interacción e inhibición del patógeno. La profundización en el conocimiento de estos mecanismos está prevista en investigaciones futuras. 


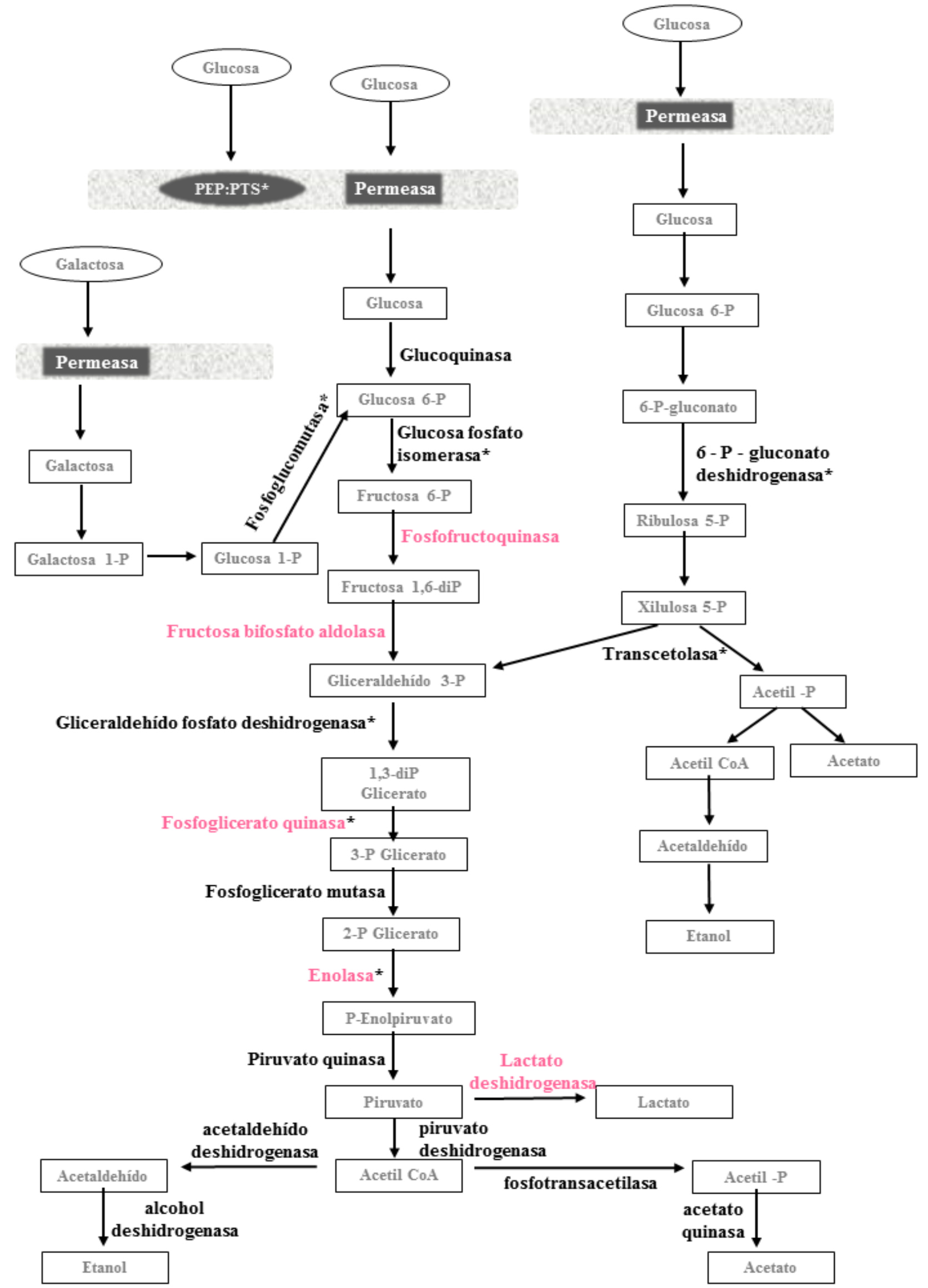

Figura 3.11. Vía glicolítica en Ent. mundtii CRL35. Las enzimas sobreexpresadas a T2 en cocultivo con respecto a su crecimiento individual (análisis $N^{\circ} \| l$ ) se encuentran en color rosado. Con asteriscos se presentan las proteínas sobreexpresadas en cocultivo a 6 h (TI) con respecto a las $30 \mathrm{~h}$ (T2) (análisis $\mathrm{N}^{\circ}$ III). 
Tabla 3.2. Proteínas sobrexpresadas durante el crecimiento en cocultivo de Ent. mundtii CRL35 con respecto a su crecimiento individual a $\mathrm{Tl}$ y $\mathrm{T} 2$ en $\mathrm{SCM}$ a $30^{\circ} \mathrm{C}$.

\begin{tabular}{|c|c|c|c|c|c|c|c|c|c|c|}
\hline Función & $\operatorname{cog}^{a}$ & Spot ${ }^{b}$ & Proteína & $\begin{array}{c}\mathrm{N}^{\circ} \mathrm{de} \\
\text { Acceso }\end{array}$ & Score ${ }^{d}$ & Gen & $\begin{array}{l}\text { PM } \\
\text { teóricoe }\end{array}$ & $\mathrm{pl}^{\mathrm{f}}$ & $\begin{array}{l}\text { Veces de } \\
\text { expresión } \\
g\end{array}$ & $\begin{array}{c}\text { Expresión diferencial } \\
\text { Cocultivo/Crec. Individual }\end{array}$ \\
\hline \multicolumn{11}{|c|}{$\mathrm{T} 1^{*}$} \\
\hline $\begin{array}{l}\text { Metabolismo } \\
\text { de } \\
\text { Carbohidratos }\end{array}$ & o & 1 & Enolasa & gi|6026 I9948 & 1120 & eno & 46496 & 4,60 & 1,9 & \\
\hline \multirow{2}{*}{$\begin{array}{l}\text { Metabolismo } \\
\text { de } \\
\text { Aminoácidos }\end{array}$} & $\begin{array}{l}E \\
F\end{array}$ & 2 & $\begin{array}{l}\text { Carbamoil } \\
\text { fosfato sintasa } \\
\text {-Subunidad } \\
\text { grande }\end{array}$ & gi|6026 | 9378 & 1170 & $\begin{array}{l}\text { AK89 } \\
-046 \\
30\end{array}$ & 117592 & 4,82 & 1,8 & (1) \\
\hline & P & 3 & $\begin{array}{l}\text { Transportador } \\
\text { ABC de } \\
\text { Metionina. } \\
\text { Proteína de } \\
\text { unión a } \\
\text { sustrato }\end{array}$ & gil602620029 & 668 & $\begin{array}{l}\text { AK89 } \\
-000 \\
90\end{array}$ & 30407 & 4,36 & 2,1 & Es \\
\hline $\begin{array}{l}\text { División } \\
\text { Celular }\end{array}$ & D & 4 & $\begin{array}{l}\text { Proteína de } \\
\text { división } \\
\text { celular FtsZ }\end{array}$ & gi|6026|8182 & 367 & $f t s Z$ & 44517 & 4,73 & 2,2 & Th \\
\hline
\end{tabular}




\begin{tabular}{|c|c|c|c|c|c|c|c|c|c|c|}
\hline Función & $\mathrm{COG}^{\mathrm{a}}$ & Spot & Proteína & $\begin{array}{c}\mathrm{N}^{\circ} \text { de } \\
\text { Acceso } \\
c\end{array}$ & $\underset{d}{S c o r e}$ & Gen & $\begin{array}{c}\text { PM } \\
\text { Teórico } \\
e\end{array}$ & $\mathrm{pl}^{\mathrm{f}}$ & $\begin{array}{c}\text { Veces de } \\
\text { expresión } \\
g\end{array}$ & $\begin{array}{l}\text { Expresión diferencial } \\
\text { Cocultivo/Crec. Individual }\end{array}$ \\
\hline \multicolumn{11}{|c|}{ T2* } \\
\hline \multirow{5}{*}{$\begin{array}{c}\text { Metabolismo } \\
\text { de } \\
\text { Carbohidra- } \\
\text { tos }\end{array}$} & G & 5 & $\begin{array}{c}\text { Fosfoglicerato } \\
\text { quinasa }\end{array}$ & gi|6026 19950 & 1040 & pgk & 42045 & 4,94 & 2,1 & \\
\hline & C & 6 & $\begin{array}{c}\text { Fructosa } \\
\text { bifosfatoaldolasa }\end{array}$ & gi|6026 I 8838 & 707 & $\begin{array}{c}\text { AK89- } \\
0781 \\
0\end{array}$ & 30955 & 4,77 & 4,0 & \\
\hline & C & 7 & $\begin{array}{c}\text { 6- } \\
\text { fosfofructokinasa }\end{array}$ & gi|6026 19230 & 1320 & pfkA & 34342 & 5,32 & 4,7 & \\
\hline & O & 8 & $\begin{array}{l}\text { Fructosa- } \\
\text { bifosfatoaldolasa }\end{array}$ & gi|6026 | 8838 & 626 & $\begin{array}{c}\text { AK89 } \\
0781 \\
0\end{array}$ & 30955 & 4,77 & 4,6 & \\
\hline & C & 9 & Enolasa & gi|6026 19948 & 1460 & eno & 46496 & 4,60 & 2,0 & \\
\hline
\end{tabular}




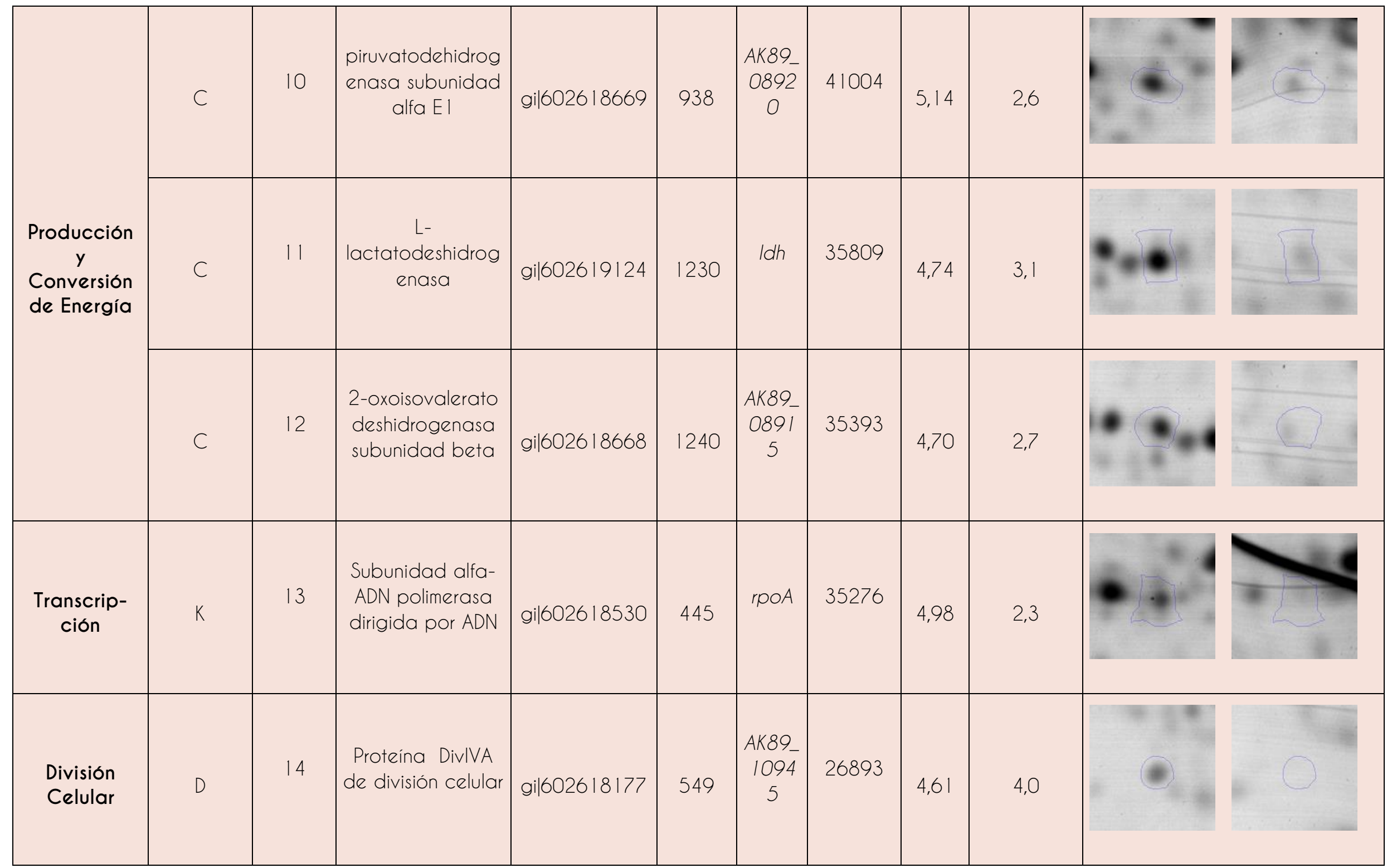




\begin{tabular}{|c|c|c|c|c|c|c|c|c|c|c|c|}
\hline Metabolismo & $\begin{array}{l}\text { I } \\
Q \\
R\end{array}$ & 15 & Oxidoreductasa & gi|6026 19024 & 1020 & $\begin{array}{c}\text { AK89 } \\
0644 \\
5\end{array}$ & 31882 & 4,77 & 3,5 & & \\
\hline $\begin{array}{c}\text { Biosíntesis } \\
\text { de Pared } \\
\text { Celular }\end{array}$ & M & 16 & $\begin{array}{l}\text { Colilglicinahidrola } \\
\text { sa }\end{array}$ & gi|6026 19043 & 951 & $\begin{array}{c}\text { AK89 } \\
0656 \\
0\end{array}$ & 36948 & 4,62 & 3,2 & $=4$ & \\
\hline $\begin{array}{c}\text { Metabolismo } \\
\text { de } \\
\text { Aminoácidos }\end{array}$ & $E$ & 17 & $\begin{array}{c}\text { Proteína } \\
\text { Hipotética } \\
\text { AK89_04275 }\end{array}$ & gi|6026 I 9580 & 938 & $\begin{array}{c}A K 89 \\
0427 \\
5\end{array}$ & 49541 & 4,58 & 2,6 & & \\
\hline $\begin{array}{c}\text { Plegamiento } \\
y \\
\text { Procesamien } \\
\text { to Proteico }\end{array}$ & $\bigcirc$ & 18 & $\begin{array}{l}\text { Chaperona } \\
\text { molecular Dnak }\end{array}$ & gi|6026 I 8370 & 1360 & dnak & 65585 & 4,63 & 2,5 & $*$ & \\
\hline $\begin{array}{l}\text { Estructura } \\
\text { Ribosomal }\end{array}$ & J & 19 & $\begin{array}{c}\text { Proteína } \\
\text { ribosomal SI }\end{array}$ & gi|6026 I 9573 & 929 & $\begin{array}{c}A K 89 \\
0424 \\
0\end{array}$ & 44564 & 4,66 & 2,5 & $(0)$ & \\
\hline
\end{tabular}




\begin{tabular}{|l|l|l|c|c|c|c|c|c|c|c|}
\hline Estrés & S & 20 & $\begin{array}{c}\text { Regulador de } \\
\text { respuesta a estrés } \\
\text { Cls24 }\end{array}$ & gil602619010 & 873 & $\begin{array}{c}\text { AK89- } \\
0635\end{array}$ & 20148 & 4,63 & 2,3 \\
\hline
\end{tabular}

*T I: 6 horas de incubación, tanto en cocultivo como en cultivo individual para Ent. mundtii.

T2: 30 horas de incubación, tanto en cocultivo como en cultivo individual para Ent. mundtii.

a Categoría funcional según la base de datos COC. Abreviaturas de una letra para las categorías funcionales COC: G: metabolismo y transporte de carbohidratos; C: producción y conversión de energía; K: transcripción; D: división celular y partición cromosómica; l: metabolismo lipídico; Q: biosíntesis, transporte y catabolismo de metabolitos secundarios; R: solo predicción funcional general; M: estructura de la pared celular y biogénesis de membrana externa; E: transporte y metabolismo de aminoácidos; O: chaperonas moleculares y funciones relacionadas; J: traducción, incluyendo estructura de ribosomas y biogénesis; S: sin predicción funcional.

b Las designaciones corresponden a las indicadas en los geles de la Figura 3.2.

c Número de acceso en la base de datos NCBI.

dEl score de proteína es - 10 * Registro (P), donde P es la probabilidad de que la coincidencia observada sea un evento aleatorio. Las puntuaciones de proteína mayores a 81 se consideran significativas $(P<0.05)$.

e Masa Molecular (Da).

f Punto isoeléctrico calculado.

9 Veces de expresión: Volúmenes normalizados de spot en cocultivo / Volúmenes normalizados spot en crecimiento individual. 
Tabla 3.3. Proteínas sobreexpresadas durante el crecimiento en cocultivo de Ent. mundtii a TI con respecto a su crecimiento en cocultivo a $\mathrm{T} 2$ en $\mathrm{SCM}$ a $30^{\circ} \mathrm{C}$

\begin{tabular}{|c|c|c|c|c|c|c|c|c|c|c|}
\hline Función & $\mathrm{COG}^{\mathrm{a}}$ & Spotb & Proteína & $\begin{array}{l}\mathrm{N}^{\circ} \text { de } \\
\text { Acceso } \\
\text { c }\end{array}$ & Score ${ }^{d}$ & Gen & $\begin{array}{l}\text { PM } \\
\text { Teóricoe }\end{array}$ & $\mathrm{pl}^{\mathrm{f}}$ & $\begin{array}{l}\text { Veces de } \\
\text { expresión } \\
g\end{array}$ & $\begin{array}{c}\text { Expresión diferencial } \\
\text { Cocultivo T1/Cocultivo T2 }\end{array}$ \\
\hline \multirow{5}{*}{$\begin{array}{c}\text { Metabolismo } \\
\text { de } \\
\text { Carbohidra- } \\
\text { tos }\end{array}$} & G & 21 & $\begin{array}{c}\text { Fosfoglucomutas } \\
\text { a/ } \\
\text { fosfomanomutas } \\
\text { a }\end{array}$ & $\begin{array}{c}\text { gi|498429| } \\
68\end{array}$ & 108 & $\begin{array}{l}\text { UAC_O } \\
1121\end{array}$ & 63509 & 4,96 & $-2,2$ & 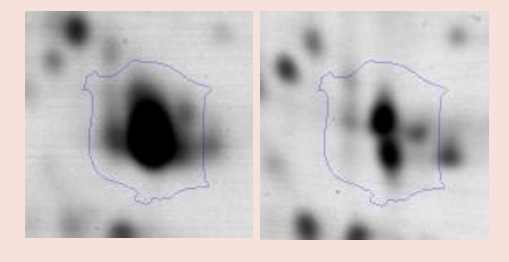 \\
\hline & G & 22 & $\begin{array}{c}\text { familia I de la } \\
\text { Fosfoglicerato } \\
\text { mutasa }\end{array}$ & $\begin{array}{c}\text { gi|4984286 } \\
89\end{array}$ & 84 & gpmA & 33999 & 6,35 & 2,0 & \\
\hline & G & 23 & $\begin{array}{l}\text { Clucosa-6- } \\
\text { fosfato } \\
\text { isomerasa }\end{array}$ & $\begin{array}{c}\text { gil7 } 366817 \\
85\end{array}$ & 138 & pgi & 49574 & 4,99 & 1,9 & \\
\hline & G & 24 & $\begin{array}{c}\text { Fosfoglicerato } \\
\text { quinasa }\end{array}$ & $\begin{array}{c}\text { gil7366815 } \\
19\end{array}$ & 186 & pgk & 42045 & 4,94 & 1,9 & e \\
\hline & C & 25 & $\begin{array}{l}\text { Fosfopiruvato } \\
\text { hidratasa }\end{array}$ & $\begin{array}{c}\text { gi|4984290 } \\
79\end{array}$ & 134 & eno & 46496 & 4,60 & 1,9 & $(2)$ \\
\hline
\end{tabular}




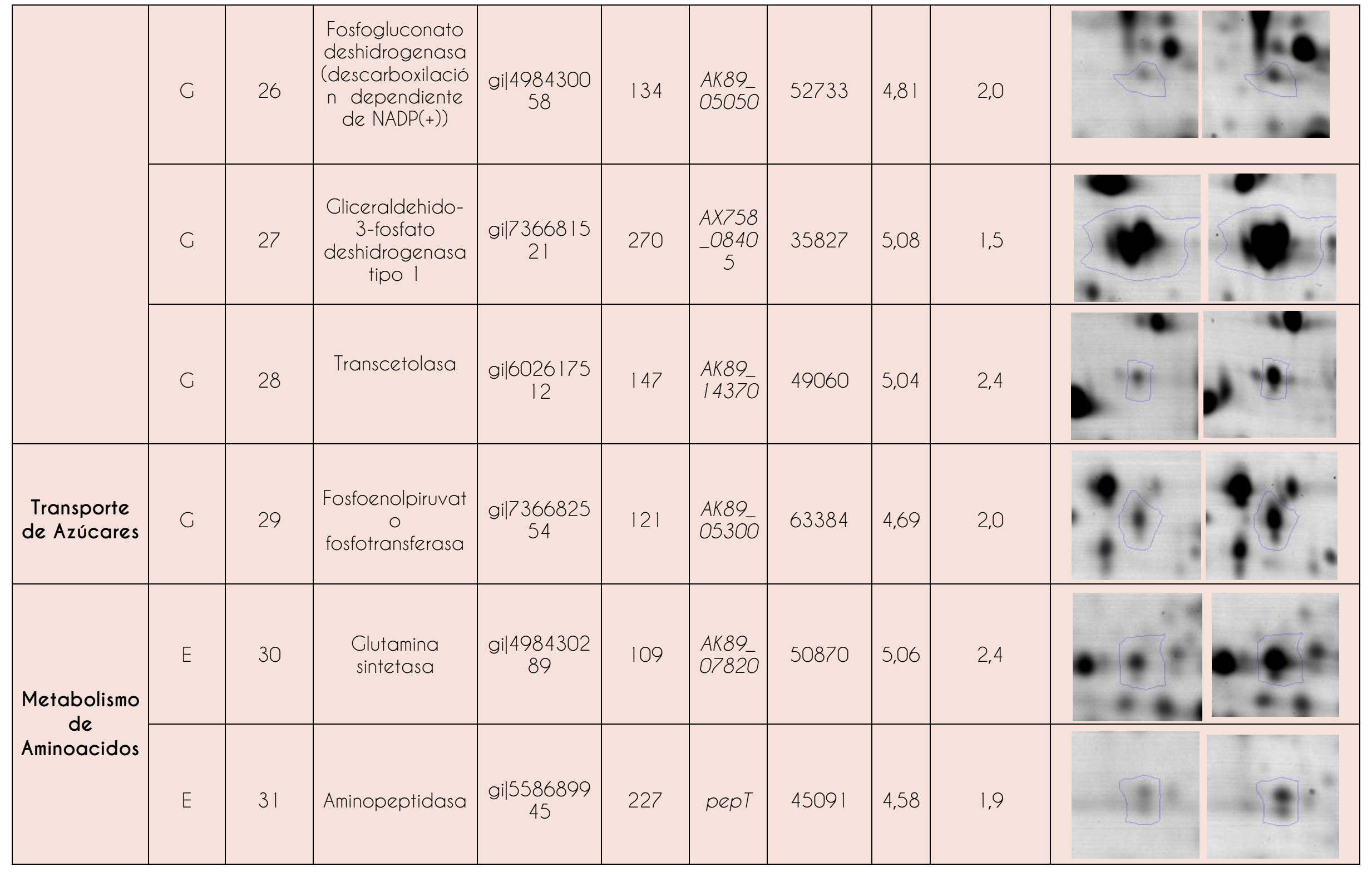




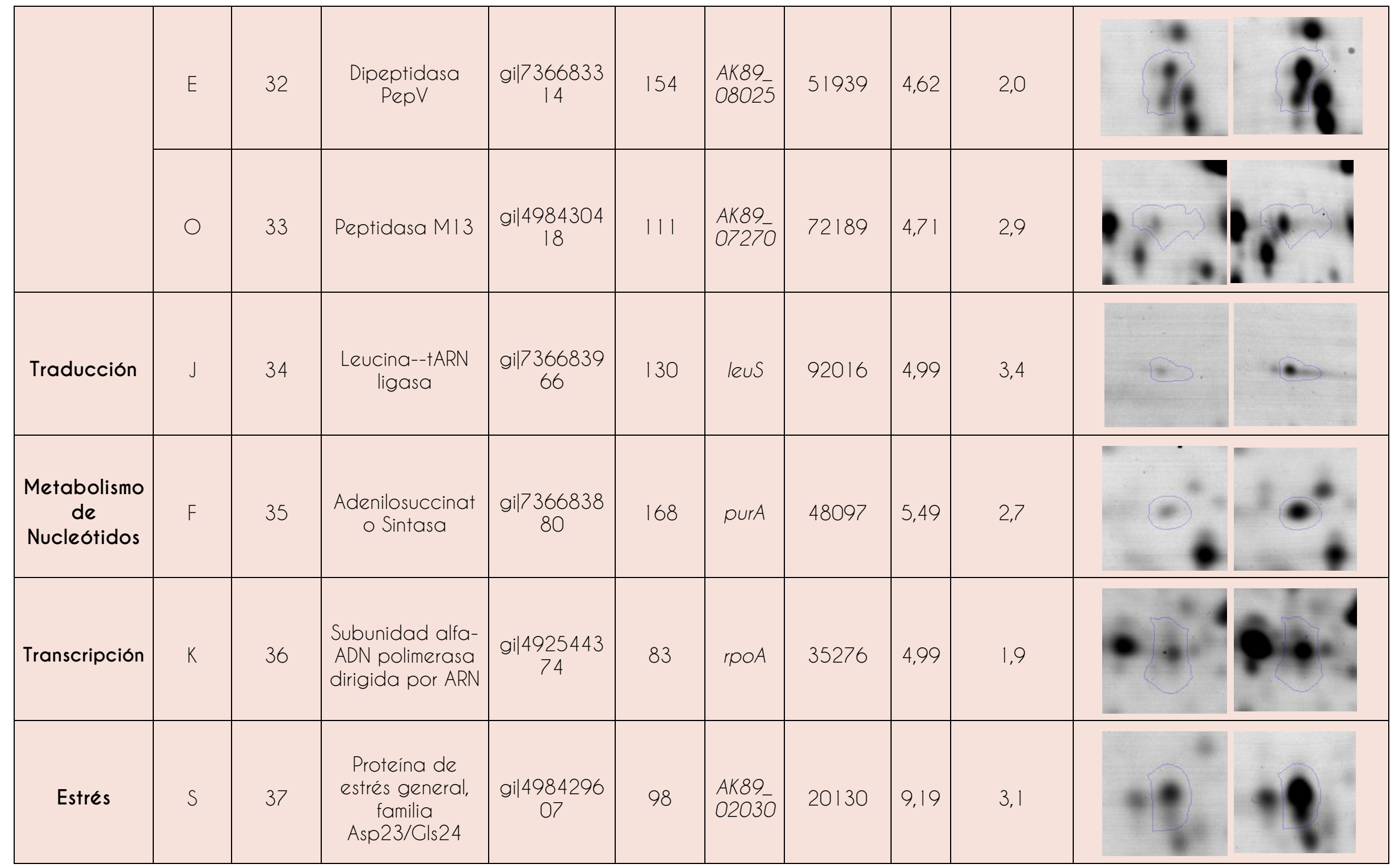




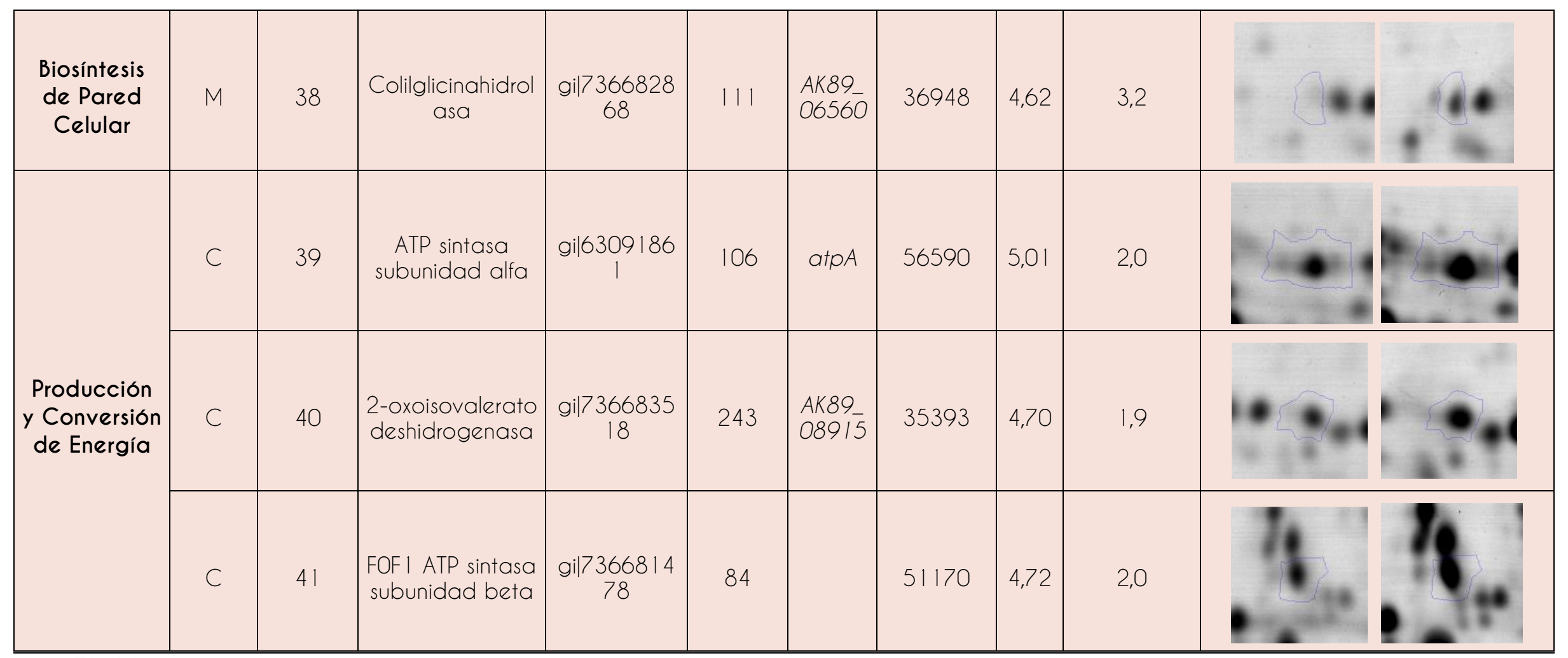

${ }^{*}$ T 1: 6 horas de incubación en cocultivo.

T2: 30 horas de incubación en cocultivo.

a Categoría funcional según la base de datos COC. Abreviaturas de una letra para las categorías funcionales COC: C: metabolismo y transporte de carbohidratos; C: producción y conversión de energía; K: transcripción; D: división celular y partición cromosómica; l: metabolismo lipídico; Q: biosíntesis, transporte y catabolismo de metabolitos secundarios; R: solo predicción funcional general; M: estructura de la pared celular y biogénesis de membrana externa; E: transporte y metabolismo de aminoácidos; O: chaperonas moleculares y funciones relacionadas; J: traducción, incluyendo estructura de ribosomas y biogénesis; S: sin predicción funcional.

b Las designaciones corresponden a las indicadas en los geles de la Figura 3.2.

"Número de acceso en la base de datos NCBI.

d El score de proteína es $-10^{*}$ Registro (P), donde P es la probabilidad de que la coincidencia observada sea un evento aleatorio. Las puntuaciones de proteína mayores a 81 se consideran significativas $(P<0.05)$.

e Masa Molecular (Da).

f Punto isoeléctrico calculado.

9 Veces de expresión: Volúmenes normalizados de spot en cocultivo T1 / Volúmenes normalizados spot en cocultivo T2. 


\section{B. Análisis proteómico para ECEH}

\section{Resultados}

Cuando se analizó la expresión diferencial de ECEH durante su crecimiento en cocultivo con Ent. mundtii CRL35 en el sistema experimental cárnico, se identificaron con éxito un total de 45 proteínas expresadas diferencialmente que mostraron un valor entre 1,7 a 2,5 veces de diferencia $(p<0.05)$. Estas fueron relacionadas a diferentes funciones celulares y asignadas a las correspondientes categorías funcionales de acuerdo a la base de datos COC, las cuales estuvieron reprimidas o sobreexpresadas según el análisis comparativo realizado (Tablas 3.4 y 3.5).

Expresión diferencial de proteínas de E. coli O 157:H7 NCTC12900 creciendo en cocultivo con respecto a su crecimiento individual

Cuando se compararon los proteomas durante el crecimiento en cocultivo con respecto al crecimiento individual en SCM, se obtuvo una represión significativa en la expresión de proteínas durante el crecimiento de ECEH en cocultivo en ambos tiempos analizados ( $\mathrm{T} 1$ y T2), con excepción de dos spots que se vieron sobreexpresados a T2.

Fueron 11 las proteínas reprimidas a T1, entre 1,7-2,5 veces disminuidas, (Tabla 3.4, Figura 3.7A), las cuales se encontraron relacionadas con:

- Metabolismo de aminoácidos (45,45\%),

- Metabolismo de nucleótidos (18,18\%),

- Traducción (9,09\%),

- Transcripción (9,09\%),

- Plegamiento y procesamiento proteico (9,09\%),

- Producción y conversión de energía (9,09\%).

Por otro lado, a T2, 20 proteínas identificadas también resultaron reprimidas entre 2,0 y 6,1 veces y solo 2 se detectaron en mayores concentraciones en cocultivo con respecto al cultivo individual (Figura 3.7B). Aquellas 20 proteínas reprimidas, se relacionaron con:

- Metabolismo de aminoácidos (42,11\%),

- Traducción (10,53\%), 
- Plegamiento y procesamiento proteico (10,53\%),

- Estrés (10,53\%),

- Transporte (10,53\%),

- Producción y conversión de energía (5,26\%),

- Metabolismo de carbohidratos y transporte de azúcares (5,26\%)

- Catabolismo de metabolitos secundarios (5,26\%)

Las dos únicas proteínas de ECEH que se sobreexpresaron en cocultivo fueron la serina hidroximetil transferasa, relacionada al metabolismo de aminoácidos y la dihidrolipoil-lisina-residuo succiniltransferasa del complejo 2-oxoglutarato deshidrogenasa, involucrada en la producción y conversión de energía (Tabla 3.4).

En resumen, el metabolismo de aminoácidos resultó mayoritariamente reprimido durante el crecimiento de ECEH en cocultivo con respecto a su crecimiento individual, en ambos tiempos evaluados.

En contraste, cuando Ent. mundtii creció en cocultivo con ECEH sobreexpresó proteínas relacionadas principalmente con el metabolismo de aminoácidos (TI), metabolismo de carbohidratos y a la producción/conversión de energía (T2). Estos resultados indicarían que ECEH habría experimentado una desventaja adaptativa durante el cocultivo con la BL (Figura 3.7B).

Expresión diferencial de proteínas de ECEH al comparar su crecimiento en cocultivo en ambos tiempos analizados (T1 y T2)

Durante el crecimiento en cocultivo de ambos microorganismos en SCM, se comparó la expresión diferencial de proteínas de ECEH a las 6 h durante su crecimiento exponencial (T1) con respecto a lo ocurrido a T2 (30 h, fase de muerte). En este estudio se identificaron 13 proteinas expresadas diferencialmente $(p<0,05$; 1,8-2,5 veces) y en todos los casos se registró sobreexpresión a las 30 h.

Se observó que las proteínas sobreexpresadas pertenecen a diferentes categorías funcionales (Tabla 3.5, Figura 3.7C), a saber:

- Producción y conversión de energía (23,08\%),

- Estrés (23,08\%),

- Metabolismo de aminoácidos (15,38\%),

- Transcripción (15,38\%),

- Transporte de azúcares (7,69\%),

- Metabolismo de nucleótidos (7,69\%), 
- Biosíntesis de pared celular (7,69\%).

De manera que cuando ECEH se encuentra en fase de muerte gatilla la sobreexpresión principalmente de proteínas de estrés y de producción de energía para hacer frente a las condiciones hostiles del ambiente incluyendo la presencia de la BL quien se encuentra en franca ventaja competitiva con respecto a ECEH en esta etapa del cocultivo. De hecho la población láctica es superior y se encuentra en una estable fase estacionaria, lo que explicaría que esta bacteria no haya gatillado la sobreexpresión de proteínas en este momento del cocultivo (Figura 3.3).

En los tres análisis comparativos realizados del proteoma de ECEH, el mayor número de proteínas expresadas diferencialmente se relacionó con metabolismo de aminoácidos, nucleótidos, estrés y producción de energía. Cuando se comparó el crecimiento en cocultivo con el crecimiento individual, se observó represión de proteínas, por el contrario cuando comparamos dos momentos diferentes del crecimiento en cocultivo se observó sobreexpresión de proteínas a las $30 \mathrm{~h}$ de incubación (T2) en SCM (Figura 3.7). 
A

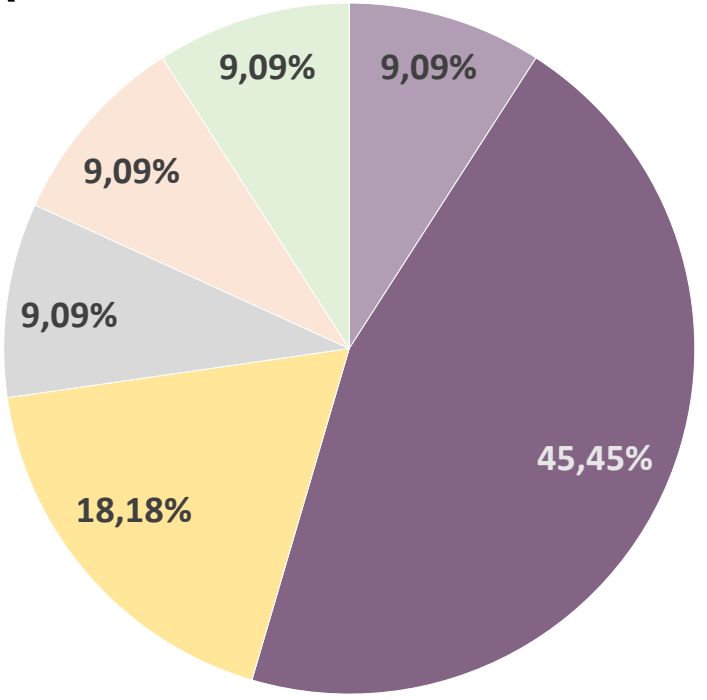

- Producción y conversión de energía

- Metabolismo de aminoácidos

Metabolismo de nucleótidos

Transcripción

Traducción

Plegamiento y procesamiento proteico

B

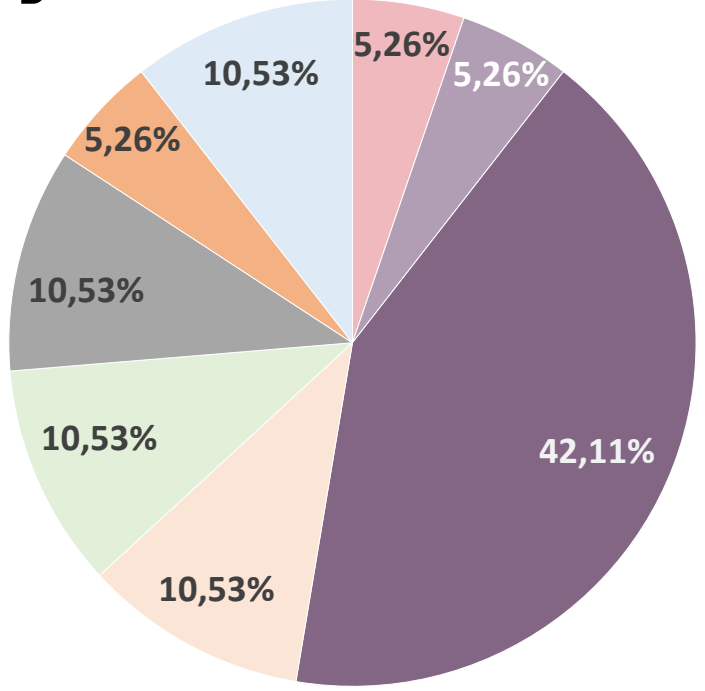

- Metabolismo de carbohidratos y transporte de azúcares

- Producción y conversión de energía

- Metabolismo de aminoácidos

Traducción

Plegamiento y procesamiento proteico

Estrés

- Catabolismo de metabolitos secundarios

Transporte 


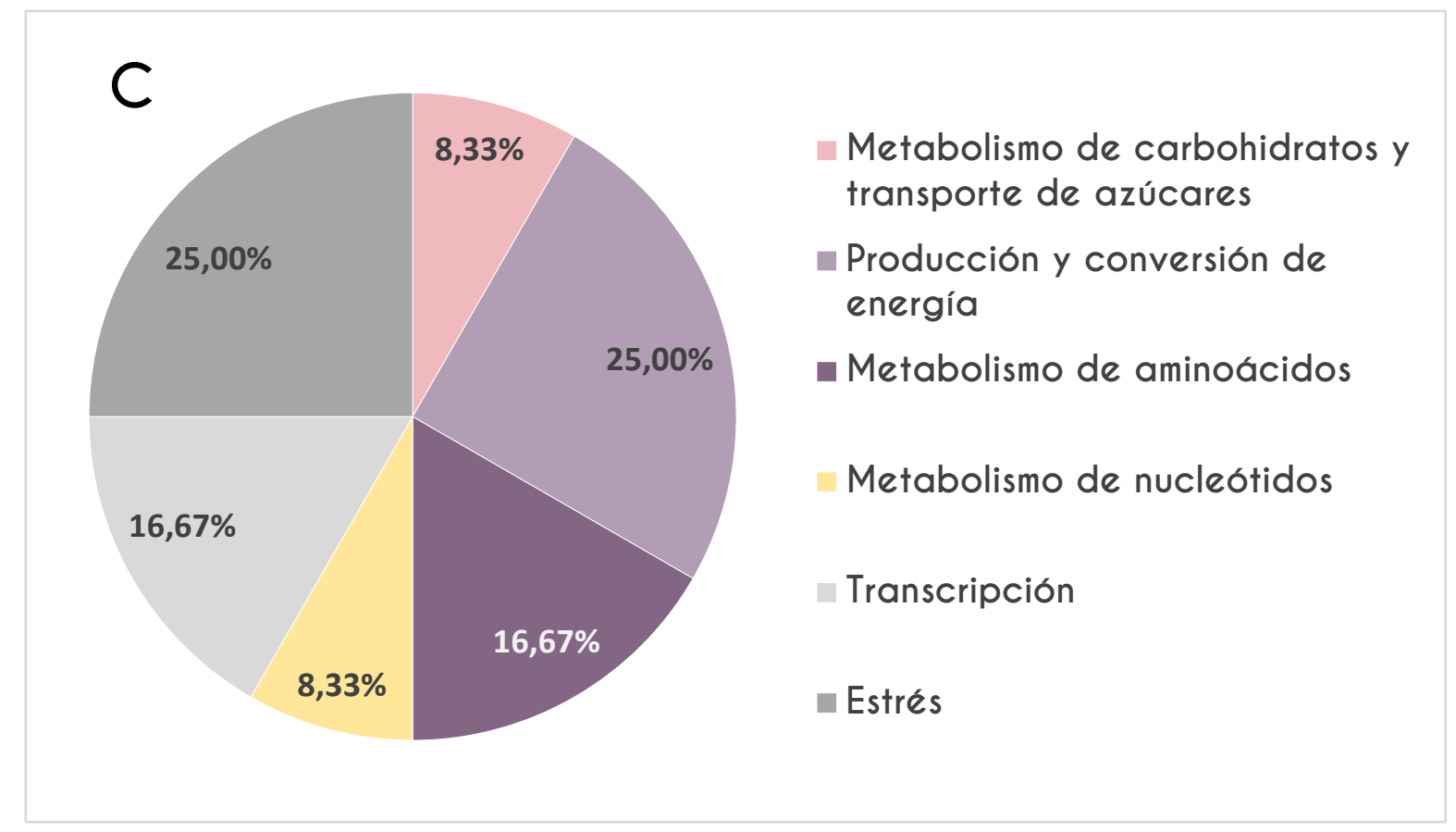

Figura 3.7. Abundancia relativa (\%) de las proteínas diferencialmente expresadas por ECEH según sus categorías funcionales: (A) Proteínas reprimidas en cocultivo TI versus cultivo individual T1; (B) Proteínas reprimidas en cocultivo T2 versus cultivo individual T2; (C) Proteínas sobreexpresadas Cocultivo T2 versus Cocultivo T1 
Análisis funcional e interacción de proteínas expresadas diferencialmente por $\underline{\text { ECEH }}$

Utilizando la base de datos, análisis y visualización STRINC v10.05 y Cytoscape v3.6.1, se construyeron las redes de interacción proteína-proteína para cada conjunto de proteínas expresadas diferencialmente por ECEH en los tres análisis proteómicos llevados a cabo (Figura 3.7): i) proteínas reprimidas por ECEH en cocultivo con respecto a su crecimiento individual a TI (Figura 3.8); ii) proteínas reprimidas por ECEH en cocultivo con respecto a su crecimiento individual a T2 (Figura 3.9), iii) proteínas de ECEH sobreexpresadas en cocultivo a T2 con respecto al cocultivo a TI (Figura 3.10). Las proteínas están representadas por nodos y la fuerza de las diferentes interacciones está representada por el grosor de las líneas que las une. En las figuras Figura 3.8A, Figura 3.9A y Figura 3.10A se muestran las redes obtenidas mediante STRINC y se destacan en círculos las interacciones de mayor intensidad observadas. Las redes obtenidas mediante el análisis en el programa Cytoscape se observan en las Figura 3.8B, Figura 3.9B y Figura 3.1OB, donde el tamaño de los nodos refleja en valores absolutos las veces de expresión de cada proteína en las condiciones estudiadas. En estas redes las proteínas sin interacción no son representadas.

Fueron 11 las proteínas reprimidas por ECEH en cocultivo con respecto a su crecimiento individual a T1, representadas por 11 nodos (Figura 3.8A). De las 11 proteínas, 5 no presentaron interacciones entre ellas, mientras que se observaron 2 grupos, de 3 proteínas cada uno, relacionados principalmente con el metabolismo y transporte de aminoácidos. Cada grupo presentó 2 interacciones entre sus proteínas. Las proteínas participantes de esta red tuvieron una diferencia de expresión de 2,5 a 1,7 veces. Si bien en este caso se trata de proteínas reprimidas, es decir, las veces de expresión constituyen valores negativos, la red construida (Figura 3.8B) exhibe las veces de expresión en valores absolutos y por lo tanto demuestra aquellas proteínas que presentaron mayor represión, evidenciándose que la proteína de unión al sustrato del transportador $A B C$ de arginina (ArtJ), 5metiltetrahidropteroil triglutamato-homocisteína metiltransferasa (MetE) y 3isopropilmalato dehidratasa subunidad grande (LeuC) fueron aquellas que mayor represión experimentaron (2,5, 2,4 y 2,3 veces respectivamente).

Por otro lado, fueron 19 las proteínas reprimidas por ECEH en cocultivo con respecto a su crecimiento individual a T2 y están representadas en 16 nodos en la Figura 3.9A, ya que la identificación de tres de los spots resultó en la misma proteína 
(glutamato descarboxilasa). En dicha red, se observa que de esas 16 proteínas, 3 no poseen interacciones con el resto y 2 presentan relación exclusiva entre ellas. Las interacciones de mayor magnitud están relacionadas con el metabolismo y transporte de aminoácidos, transcripción y modificaciones postraduccionales (Figura 3.9A). Este grupo de proteínas fueron reprimidas entre 2,0 y 6,1 veces (valores absolutos) en cocultivo con respecto al cultivo individual de ECEH a T2, donde la proteína periplásmica de unión a taurina (TauA) fue la que mayor represión demostró (6,1 veces), seguida por la proteína taurina dioxigenasa dependiente de alfacetoglutarato (Taud) (4,5 veces).

En la red observada en la Figura 3.10A se representan las 13 proteínas sobreexpresadas en cocultivo a T2 con respecto a T1, de las cuales 6 de ellas no presentó interacción con el resto. Las interacciones de mayor intensidad entre las proteínas del grupo fueron aquellas pertenecientes a producción y conversión de energía y a modificaciones postraduccionales. Este conjunto de proteínas fueron sobreexpresadas entre 1,9 y 5,2 veces por ECEH a T2 en cocultivo, siendo PflB (formato acetiltransferasa) y ClpB (proteína chaperona ClpB) aquellas con mayor diferencia de expresión (5,2 y 3,8 veces respectivamente) (Figura 3.1OB). 
A

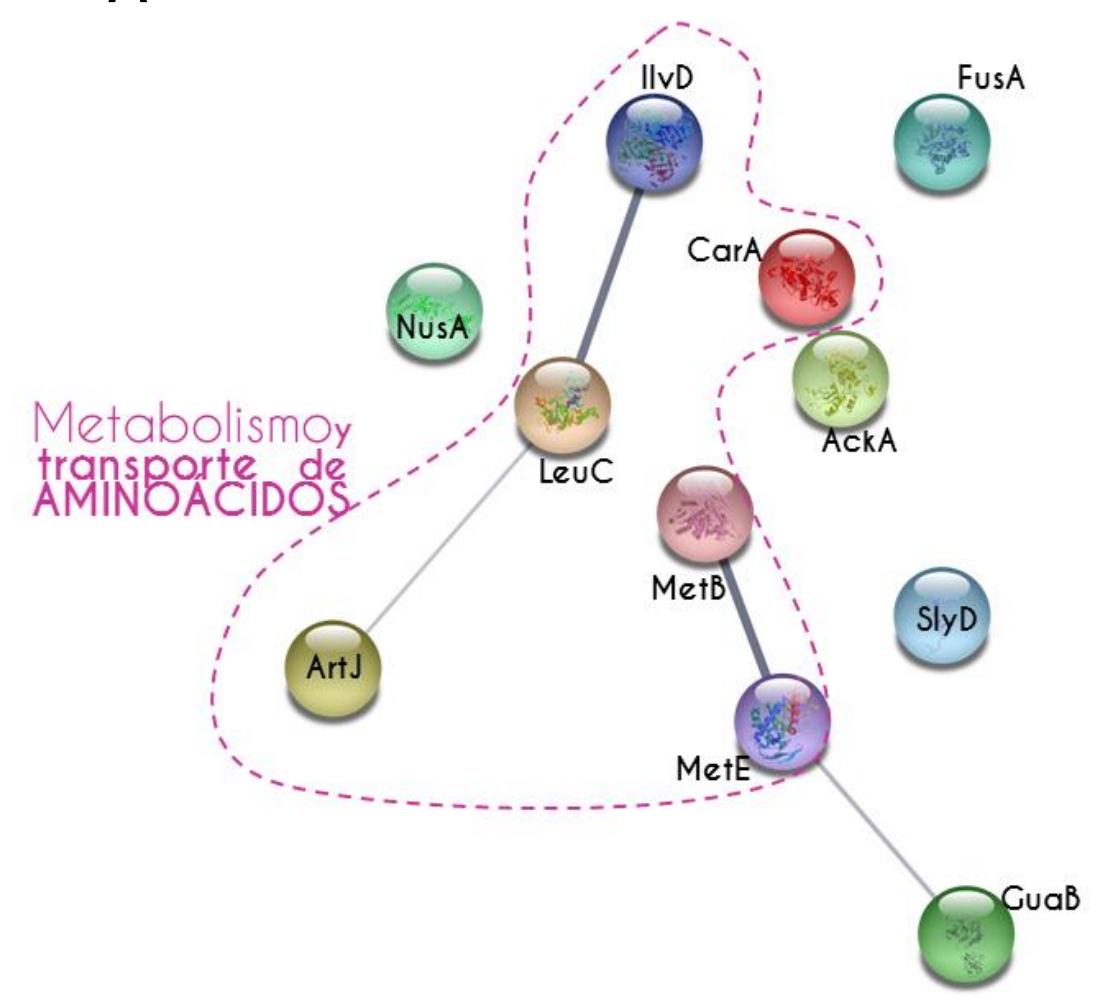

B

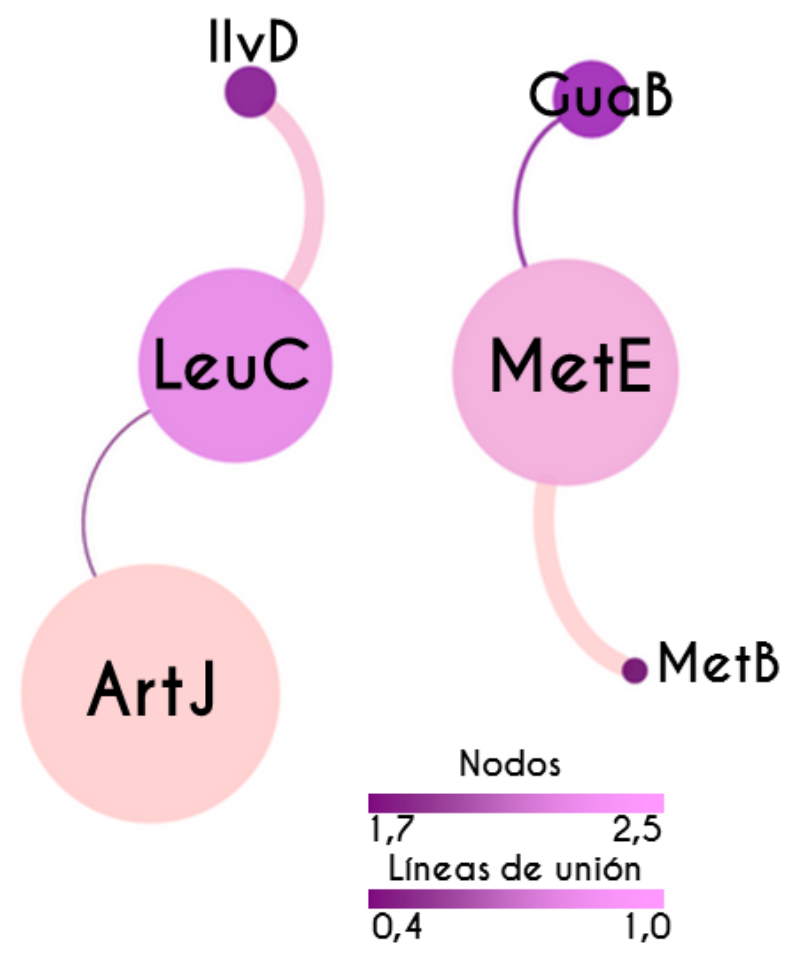

Figura 3.8. Red de interacción de proteínas reprimidas por ECEH en cocultivo con respecto a su cultivo individual a TI. Las proteínas están representadas por nodos mientras que sus interacciones por líneas. La fuerza de las diferentes interacciones está dada por el grosor de las lineas. (A) Red construida utilizando STRINC v 10.05. Los círculos agrupan las proteínas relacionadas con el metabolismo y transporte de aminoácidos. (B) Red construida utilizando Cytoscape v3.6.1. El tamaño de los nodos representa de forma proporcional las veces de expresión en valores absolutos de cada proteína representada. La gama de colores presentada en líneas de unión y nodos indican la magnitud de la interacción y veces de expresión respectivamente, siendo los mayores valores representados en color rosado y los menores en color violeta. 
A

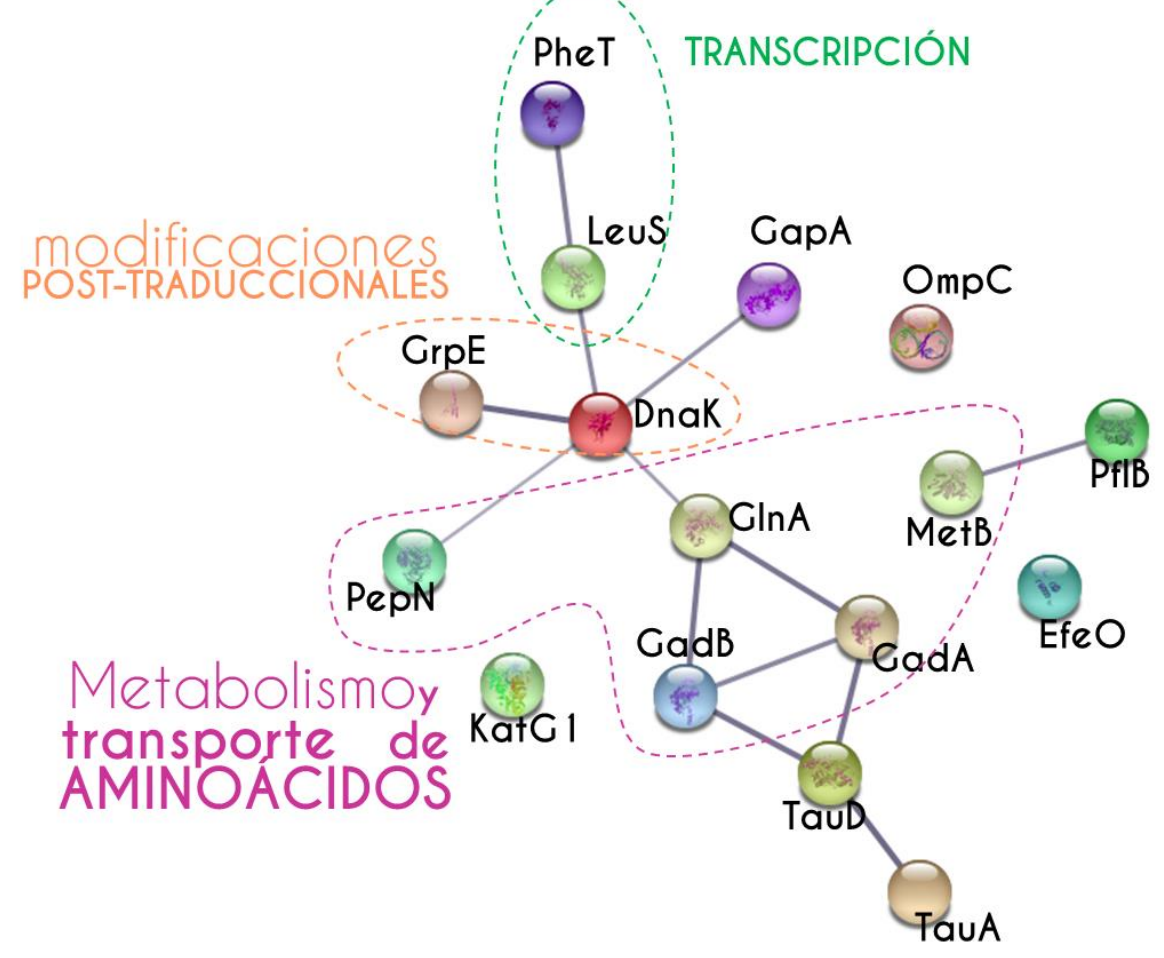

B

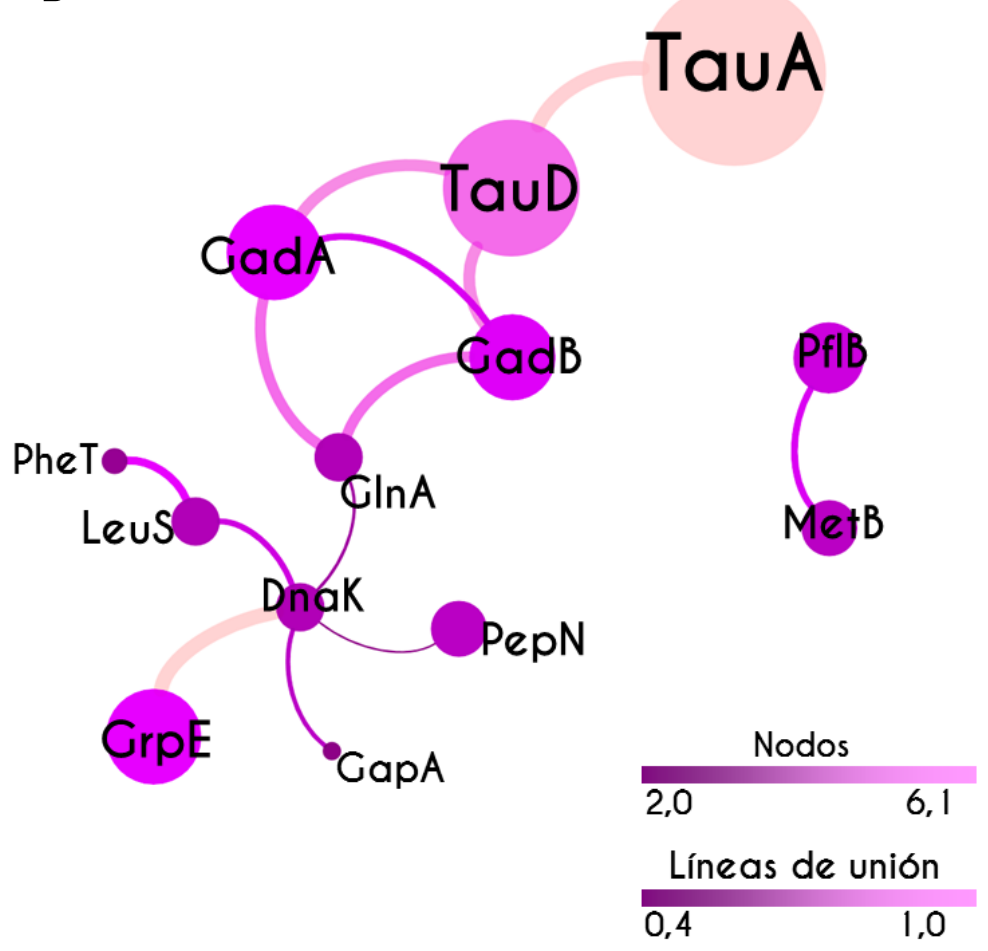

Figura 3.9. Red de interacción de proteínas reprimidas por ECEH en cocultivo con respecto a su cultivo individual a T2. Las proteínas están representadas por nodos mientras que sus interacciones por líneas. La fuerza de las diferentes interacciones está dada por el grosor de las líneas. (A) Red construida utilizando STRING v 10.05. Los círculos agrupan las proteínas relacionadas con el metabolismo y transporte de aminoácidos, transcripción y modificaciones postraduccionales. (B) Red construida utilizando Cytoscape v3.6.1. El tamaño de los nodos representa de forma proporcional las veces de expresión en valores absolutos de cada proteína representada. La gama de colores presentada en líneas de unión y nodos indican la magnitud de la interacción y veces de expresión respectivamente, siendo los mayores valores representados en color rosado y los menores en color violeta. 
A

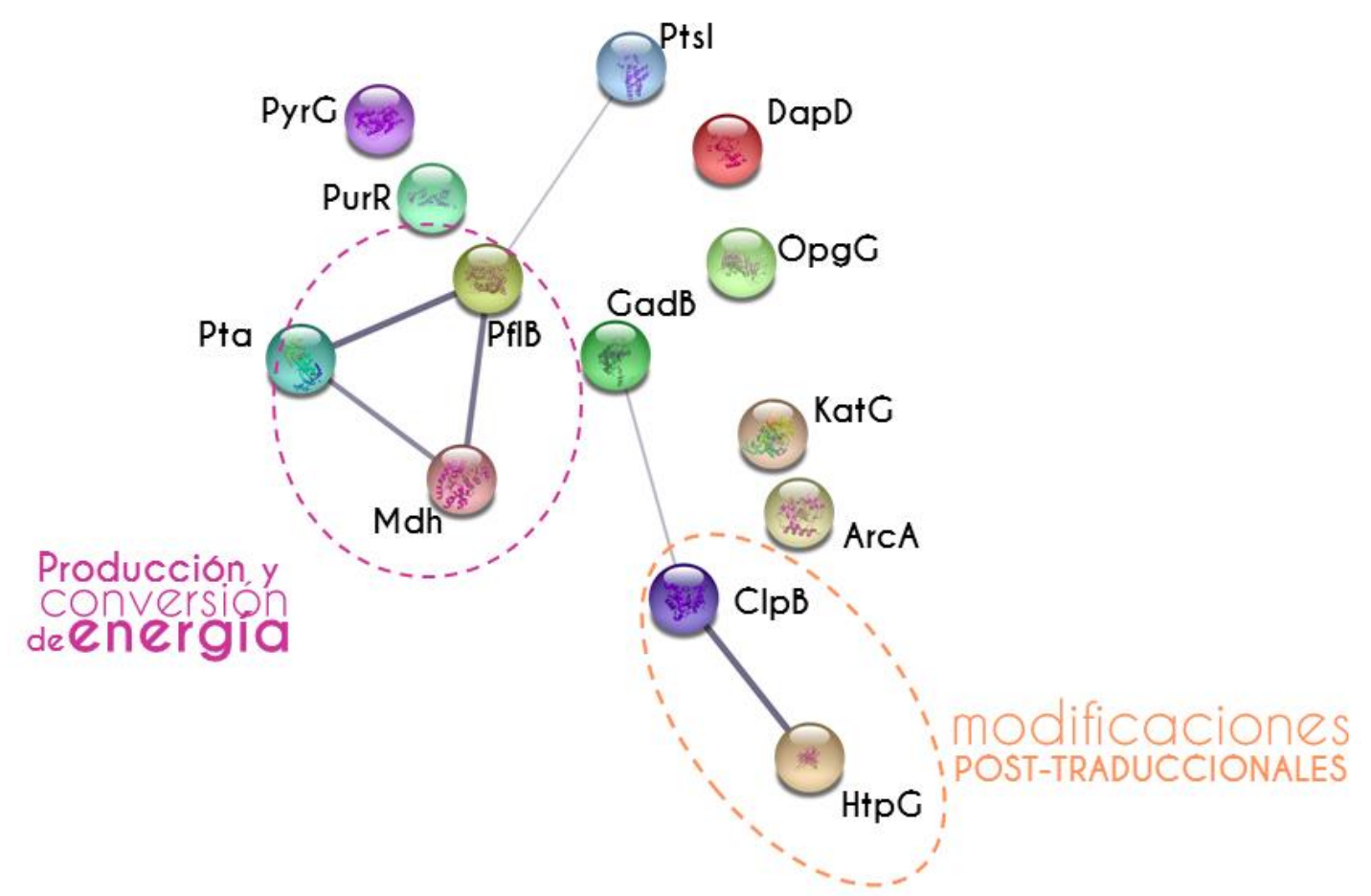

B

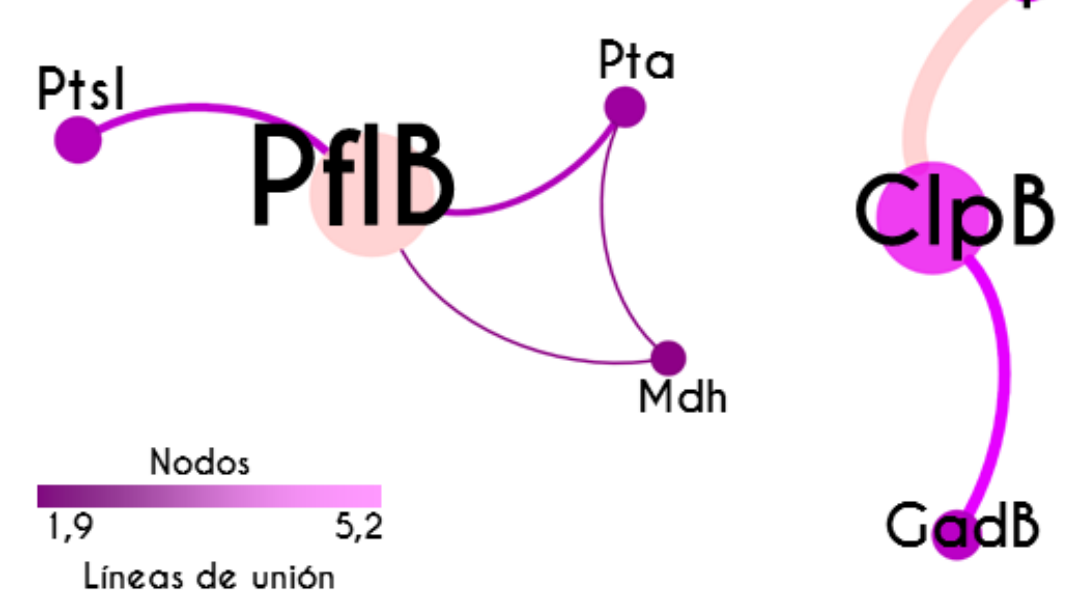

Figura 3.10. Red de interacción de proteínas sobreexpresadas en cocultivo a T2 con respecto al cocultivo T1. Las proteínas están representadas por nodos mientras que sus interacciones por líneas. La fuerza de las diferentes interacciones está dada por el grosor de las líneas. (A) Red construida utilizando STRING v 10.05. Los círculos agrupan las proteínas relacionadas con la producción y conversión de energía y modificaciones post-traduccionales. (B) Red construida utilizando Cytoscape v3.6.1. El tamaño de los nodos representa de forma proporcional las veces de expresión de cada proteína representada. La gama de colores presentada en líneas de unión y nodos indican la magnitud de la interacción y veces de expresión respectivamente, siendo los mayores valores representados en color rosado y los menores en color violeta. 


\section{Discusión}

Al comparar con su crecimiento individual, ECEH evidenció una fuerte represión de proteínas pertenecientes a diferentes grupos funcionales tanto a 6 como a $30 \mathrm{~h}$ de crecimiento en cocultivo con la BL. La mayor proporción de proteínas reprimidas se relacionaron con el metabolismo de aminoácidos. Además, en las primeras horas de incubación ( $\mathrm{T}$ ) , también se encontraron reprimidas proteínas pertenecientes al metabolismo nucleotídico, mientras que en fase de muerte (T2), se desataca también la disminución en la expresión de proteínas involucradas en la traducción, plegamiento proteico y estrés. Este comportamiento de ECEH en presencia de la BL, refleja el menor rendimiento metabólico y fisiológicamente se observa una entrada anticipada en fase de muerte, la cual se produce recién a las 96 h cuando ECEH crece individualmente.

En contraste, como se describió anteriormente, Ent. mundtii fue capaz de sobreexpresar un amplio abanico de proteínas cuando creció en cocultivo con el patógeno, destacándose entre ellas las pertenecientes al metabolismo de carbohidratos y conversión de energía, lo cual refleja una actividad metabólica superior de la BL cuando conviven ambos microorganismos en cocultivo respecto al cultivo puro. Asimismo, se puede sugerir que la bacteria patógena ejerce un efecto neutro o ligeramente positivo en la actividad metabólica de la BL ya que se observa una cinética de crecimiento poco modificada a lo largo del tiempo y con fase estacionaria estabilizada respecto a su crecimiento independiente.

No hay antecedentes entorno al estudio de la expresión diferencial de proteínas de ECEH en cocultivo con otros microorganismos, sin embargo, se encuentra ampliamente estudiada su expresión de proteínas en respuesta a diferentes estímulos estresantes, con el fin de comprender los mecanismos que gobiernan la tolerancia y/o debilidad de este microorganismo a las distintas estrategias utilizadas para combatirlo. En este sentido, Bae y col. (2018) realizaron un análisis proteómico comparativo de E. coli O 157: H7 con el fin de comprender su resistencia aumentada al tratamiento con ácido acético luego de la adición de sal. En contraste a lo esperado, y en armonía con lo obtenido en este trabajo, las proteínas expresadas diferencialmente no se relacionaron principalmente con proteínas de estrés, sino en su mayoría fueron proteínas metabólicas las que se encontraron diferencialmente expresadas. Es decir que la tolerancia y/o debilidad en respuesta a diferentes condiciones estresantes no siempre son el resultado de la síntesis de proteínas 
relacionadas exclusivamente con estos fenómenos; por lo tanto, es necesario realizar mayores investigaciones en este sentido, para dilucidar los mecanismos moleculares subyacentes.

Es necesario recordar que cuando las bacterias se someten a un factor de estrés intenso (shock), son capaces de desarrollar resistencia a factores de estrés ambiental diferentes, lo cual se conoce como "tolerancia cruzada". La exposición a dichos factores de estrés ambiental, inducen la expresión de proteínas conocidas como "proteínas de choque", cuya función principal es reparar el daño causado por el factor de estrés o eliminar los agentes de estrés (Yousef y Courtney, 2003). El regulador maestro de la respuesta general al estrés en $E$. coli consiste en una subunidad sigma de la ARN polimerasa, el factor RpoS $\left(\sigma^{S}\right)$, que controla la expresión de más de 35 genes involucrados en la respuesta general al estrés (Bae y col., 2018). En nuestro estudio, las proteínas de estrés no fueron el grupo mayoritario afectado por la presencia de la bacteria láctica, lo cual indicaría que el patógeno no logró poner en marcha su complejo sistema de resistencia y tolerancia frente a las condiciones desfavorables producidas por la presencia de la cepa láctica en el nicho cárnico. Por el contrario, como se destacó anteriormente, aquellas más afectadas fueron las proteínas involucradas en diferentes vías metabólicas.

Por su parte, Bi y col. (2017) estudiaron las bases moleculares involucradas en la formación de células de E. coli O 157:H7 subletalmente lesionada (SIC) inducida por dióxido de carbono de alta presión (HPCD: High Pressure Carbon Dioxide) utilizando métodos proteómicos libres de geles (iTRAQ). Según los resultados obtenidos por este grupo, las SIC sobrevivieron al tratamiento con HPCD al reducir la descomposición de carbohidratos, el transporte y el metabolismo de los lípidos, el transporte y el metabolismo de los aminoácidos, la transcripción y la traducción, la replicación y reparación del ADN. Los autores proponen la formación de SIC con baja actividad metabólica como una estrategia de supervivencia de E. coli $\bigcirc 157$ : H7 contra HPCD. En línea con este razonamiento, la represión general observada en las proteínas de ECEH que arrojaron nuestros estudios, podría leerse también como una táctica o habilidad del patógeno para intentar sobrevivir en este escenario hostil dominado por la cepa láctica. Sin embargo, según los resultados fisiológicos en este estudio de tesis, ECEH se encontraba en proceso de muerte acelerada por la presencia de Ent. mundtii, de manera que, aun con la represión proteica observada pudo cursar la fase log hasta las $8 \mathrm{~h}$, similar a lo observado durante su crecimiento individual y luego entrar indefectiblemente en fase de muerte. No 
obstante, es necesario tener en cuenta la posibilidad de recuperación de dichas células remanentes y subletalmente lesionadas del patógeno. De hecho, CarciaConzalez y col. (2007), postularon que las SIC generadas durante el tratamiento con HPCD podrían recuperarse durante el almacenamiento en condiciones favorables, lo que representa un riesgo potencial para la salud. Es por eso que cobra gran importancia la idea de implementar la combinación de barreras adicionales contra el patógeno a fin de atacarlo de manera estratégica y no permitir la recuperación de dichas células subletalmente lesionadas. Este enfoque fue descripto por Leistner (1994) como "tecnología de obstáculos", y propone la utilización de múltiples barreras de pequeña intensidad en lugar de un factor antimicrobiano de mayor magnitud para lograr mayor efectividad de conservación y minimizar la pérdida de calidad organoléptica del alimento.

Por otro lado, Kocharunchitt y col. (2012) llevaron a cabo un interesante análisis transcriptómico y proteómico integrado para determinar la respuesta fisiológica de la cepa Sakai E. coli O 157: H7 a condiciones de baja temperatura y actividad de agua experimentadas durante el enfriamiento de canales bovinas en aire frío. El análisis transcriptómico reveló la activación del regulador maestro de respuesta al estrés RpoS. En contraste, los datos proteómicos revelaron que varios procesos involucrados en la síntesis de proteínas fueron reprimidos, sugiriendo que durante el crecimiento en estas condiciones, en E. coli podría haber transcripción para producir el ARNm requerido para responder al estrés, pero carecer de los recursos celulares necesarios para la traducción. Los resultados obtenidos en este trabajo son coincidentes con estos reportes, y revelaron además que existe una represión general de proteínas cuando ECEH crece en cocultivo con una BL, lo cual podría sugerir también que existe una posible deficiencia en el aparato de traducción del microorganismo en estas condiciones, que no implica necesariamente una disminución en el mecanismo de transcripción.

Cuando se comparó el crecimiento en cocultivo con el crecimiento individual de ECEH, se observó represión de proteínas del patógeno en el cocultivo, por el contrario, cuando se analizaron comparativamente dos momentos del crecimiento en cocultivo se observó sobreexpresión de proteínas a las 30 h de incubación (T2), momento en el cual ECEH atravesaba su fase de muerte. Es importante mencionar que entre las proteínas sobreexpresadas, aquellas relacionadas con el metabolismo de aminoácidos y carbohidratos, así como también proteínas de estrés fueron 
predominantes. Esto posiblemente está ocurriendo en respuesta a su lucha por la supervivencia y/o para evitar la muerte indeclinable que está ocurriendo en ese momento. Sin embargo, en el mismo análisis comparativo, se observó que el microrganismo competidor, Ent. mundtii presentaba una sobreexpresión de proteínas a las $6 \mathrm{~h}$ de cocultivo, relacionadas principalmente con el metabolismo del azúcar y el nitrógeno. Esto podría considerarse como una estrategia para lograr una elevada producción de energía y un óptimo crecimiento, estableciendo una ventaja competitiva respecto a E. coli.

En resumen, los resultados obtenidos a partir del análisis proteómico abordado, sustentan el comportamiento fisiológico observado previamente: ECEH en franca desventaja de supervivencia frente a la cepa láctica manifestándose como un microorganismo en vías de extinción cuando crece en el sistema cárnico en presencia de Ent. mundtii. En esta situación de mayor vulnerabilidad del patógeno se podría esperar que la aplicación de barreras adicionales para su control sean más efectivas.

La información recopilada a través de este enfoque proteómico contribuye a dilucidar la respuesta adaptativa global de E. coli O157:H7 en un ambiente cárnico para permitir la selección y/o el desarrollo de potenciales estrategias efectivas para desactivar este patógeno. 
Tabla 3.4. Proteínas expresadas diferencialmente por ECEH durante su crecimiento en cocultivo con Ent. mundtii CRL35 con respecto a su crecimiento individual a $\mathrm{T} 1$ y $\mathrm{T} 2$ en $\mathrm{SCM}$ a $30^{\circ} \mathrm{C}$.

\begin{tabular}{|c|c|c|c|c|c|c|c|c|c|}
\hline Función & $\mathrm{COG}^{\mathrm{a}}$ & Proteína & $\begin{array}{c}\mathrm{N}^{\circ} \text { de } \\
\text { Acceso }\end{array}$ & Score ${ }^{d}$ & Gen & $\begin{array}{c}\text { PM } \\
\text { teórico } \\
d\end{array}$ & $\mathrm{pl}^{e}$ & $\begin{array}{l}\text { Veces de } \\
\text { expresión } \\
f\end{array}$ & $\begin{array}{c}\text { Expresión diferencial } \\
\text { Cocultivo / Crecim. } \\
\text { Individual }\end{array}$ \\
\hline \multicolumn{10}{|c|}{$\mathrm{T} 1 *$} \\
\hline $\begin{array}{c}\text { Producción } \\
y \\
\text { Conversión } \\
\text { de Energía }\end{array}$ & C & Acetato quinasa & gi|446017850 & 923 & ackA & 43619 & 5,85 & $-1,8$ & (a) \\
\hline $\begin{array}{l}\text { Transcrip- } \\
\text { ción }\end{array}$ & K & $\begin{array}{l}\text { Factor de } \\
\text { elongación de } \\
\text { transcripción } \\
\text { nusA, parcial }\end{array}$ & gi|77 1529055 & 1020 & nusA & 42261 & 4,53 & $-1,8$ & $\begin{array}{l}e \\
y\end{array}$ \\
\hline $\begin{array}{l}\text { Metabolismo } \\
\text { de } \\
\text { Aminoácidos }\end{array}$ & $E$ & $\begin{array}{c}5- \\
\text { metiltetrahidropter } \\
\text { oil triglutamato - } \\
\text { homocisteína } \\
\text { metiltransferasa }\end{array}$ & gi|446076045 & $\begin{array}{l}1220 \\
1220 \\
1210\end{array}$ & metE & 85126 & 5,61 & $\begin{array}{l}-2,4 \\
-2,4 \\
-2,1\end{array}$ & 6 \\
\hline
\end{tabular}




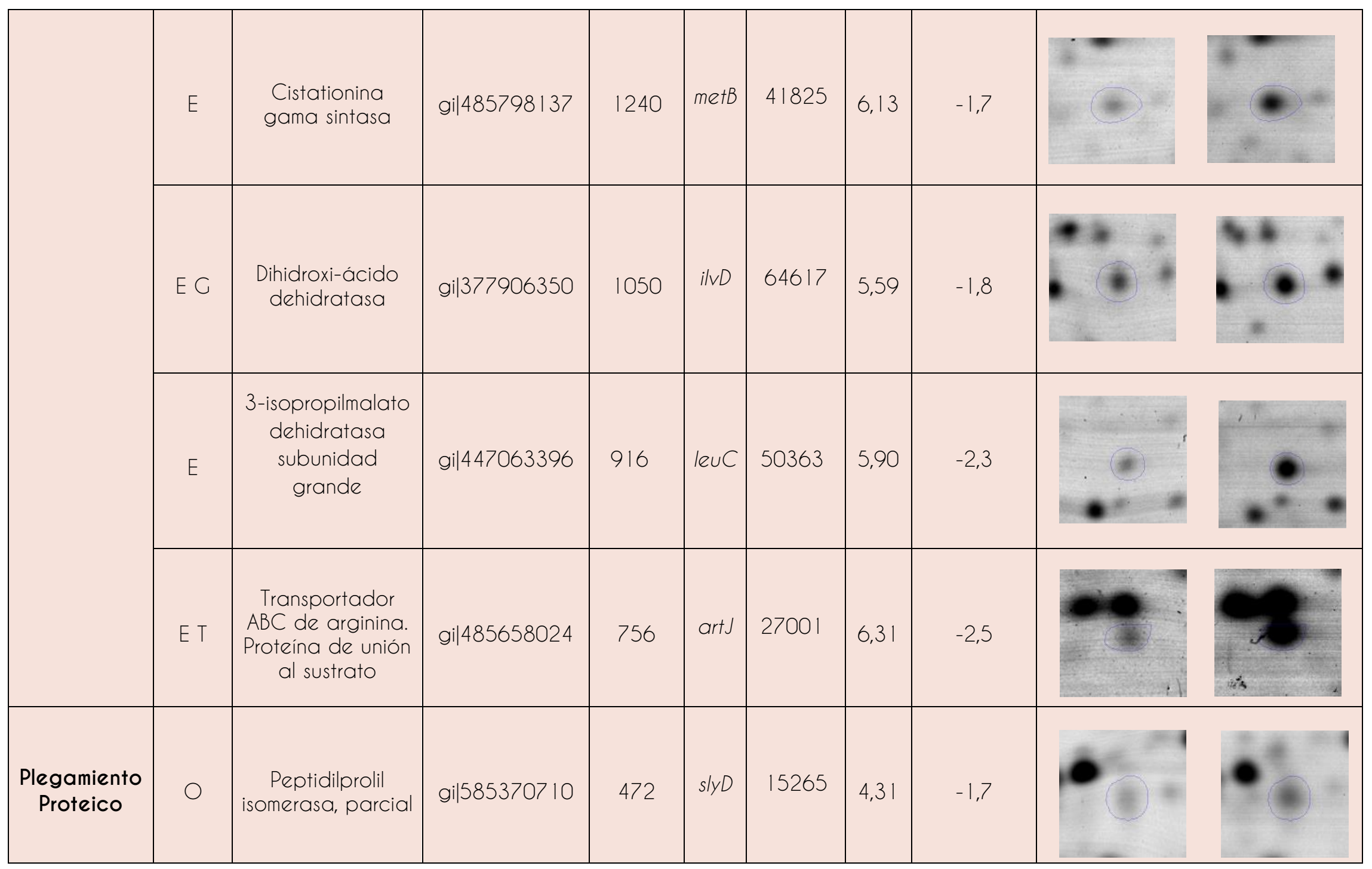




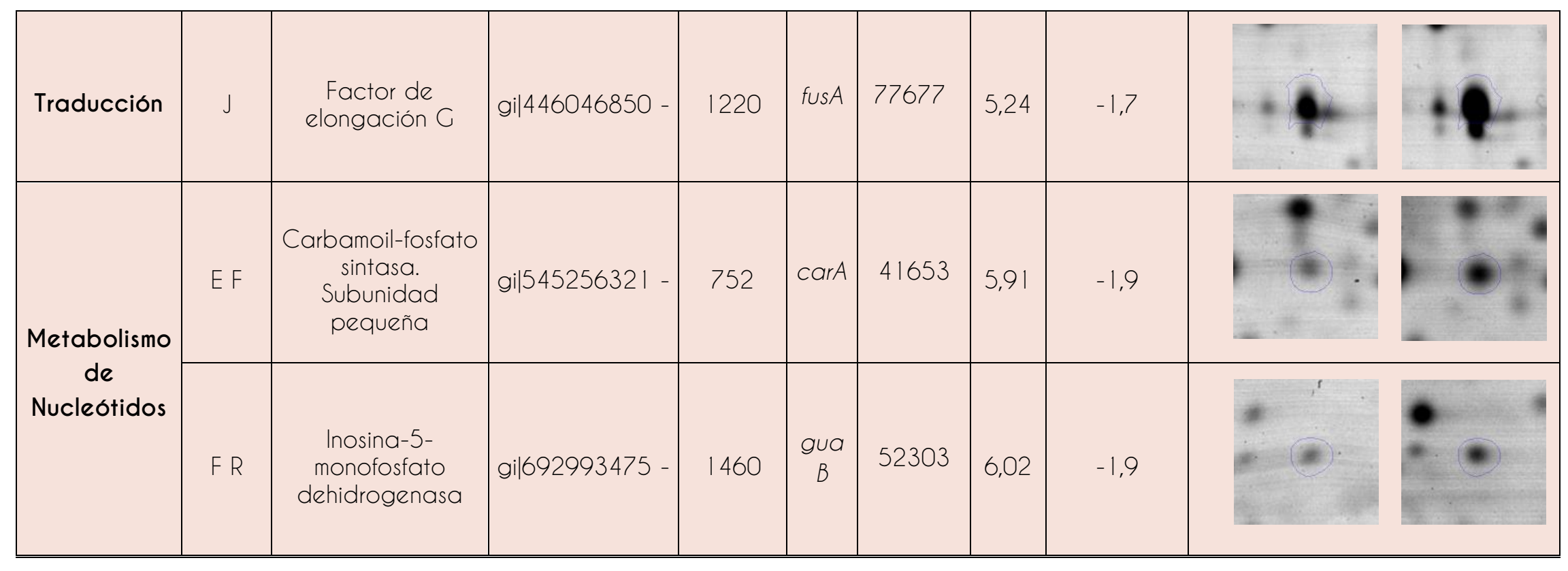




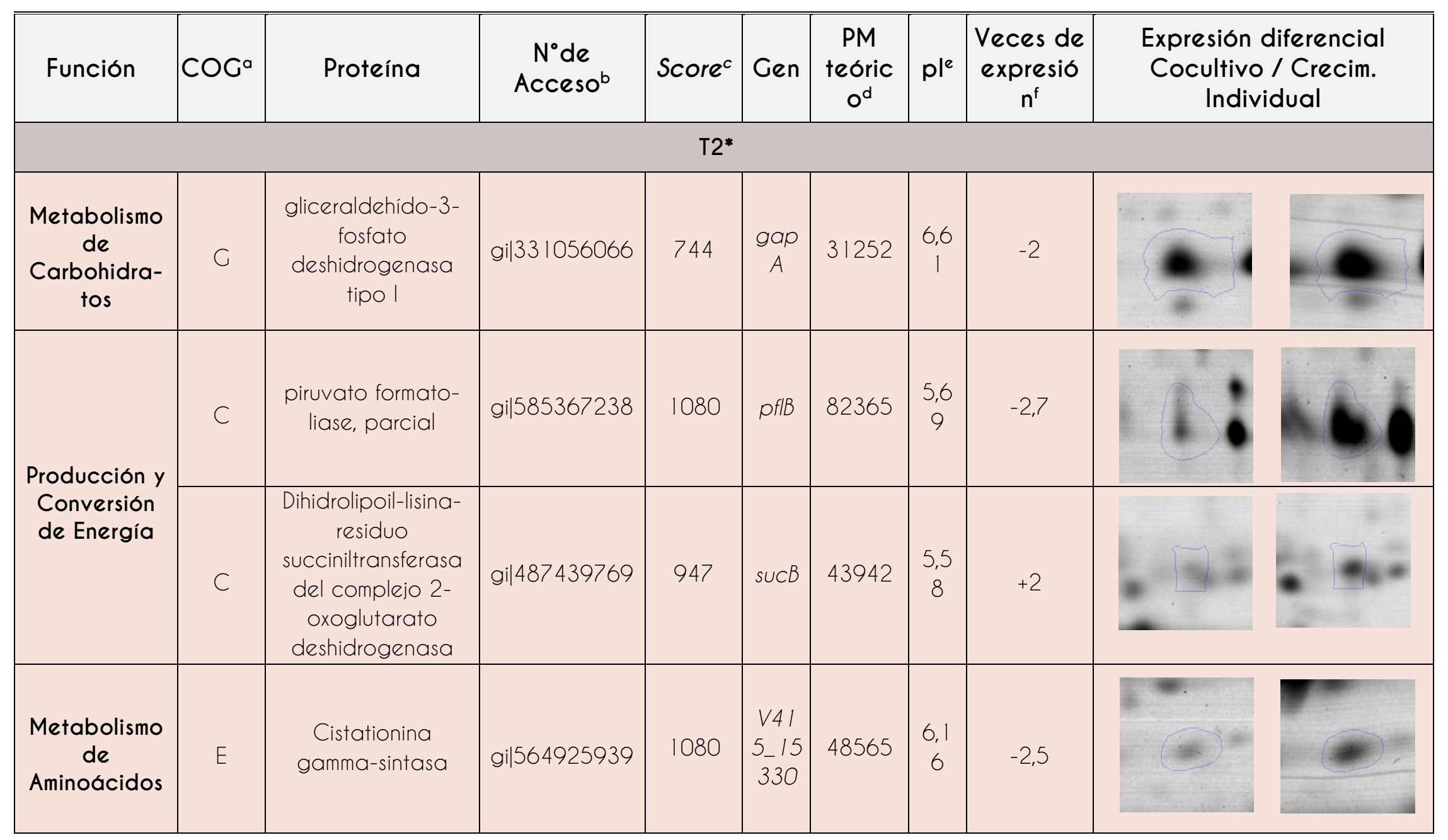




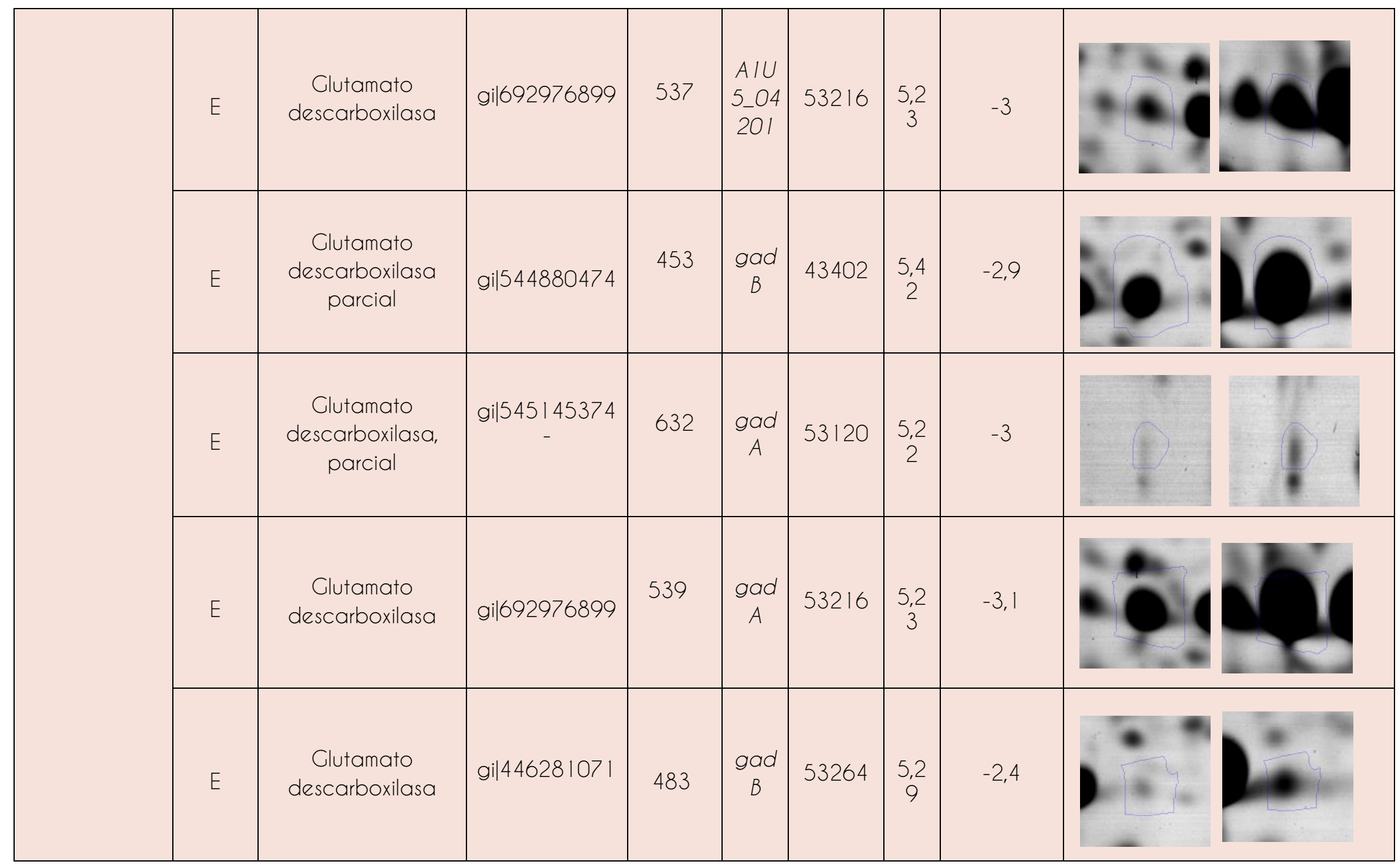




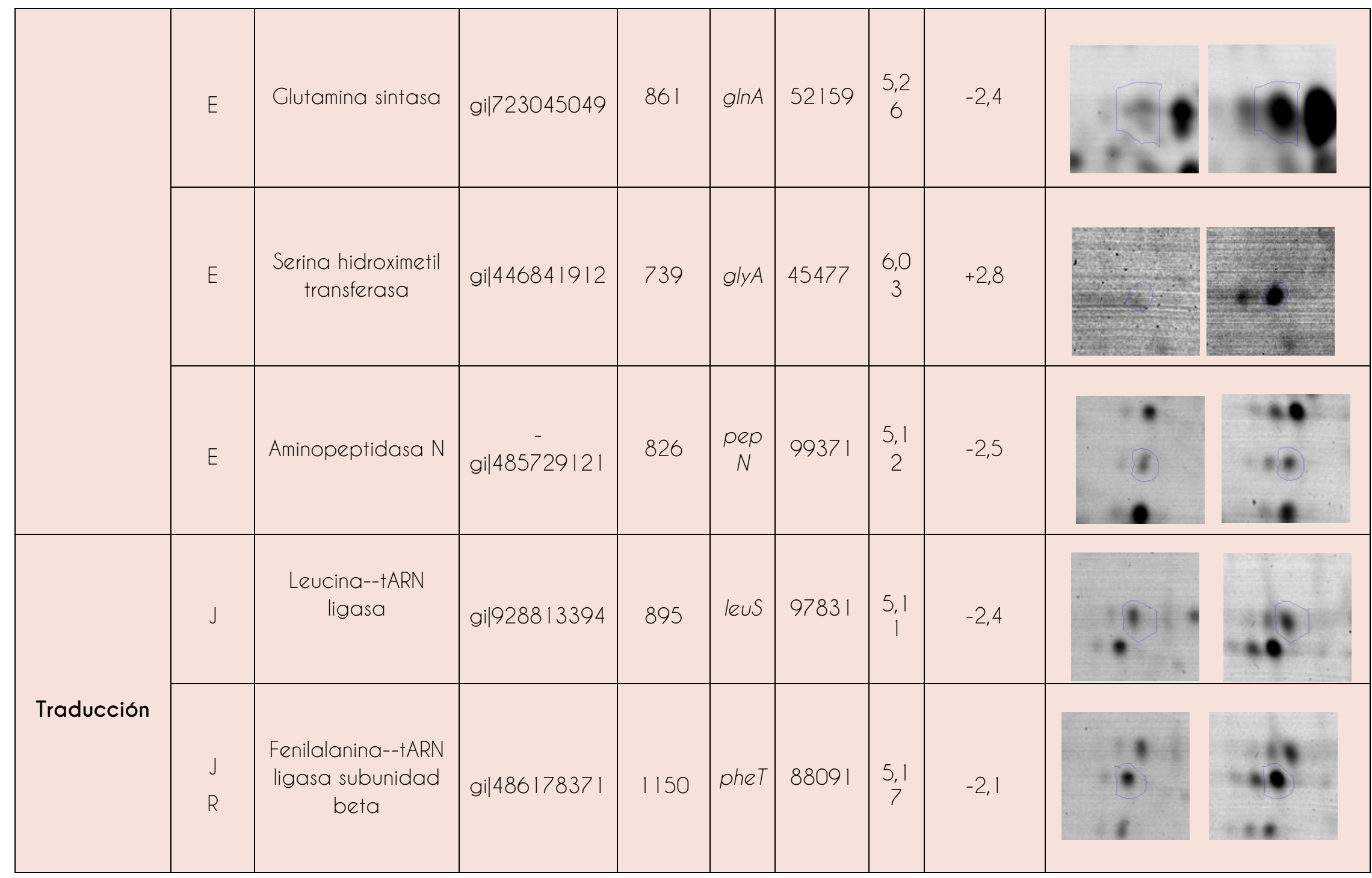




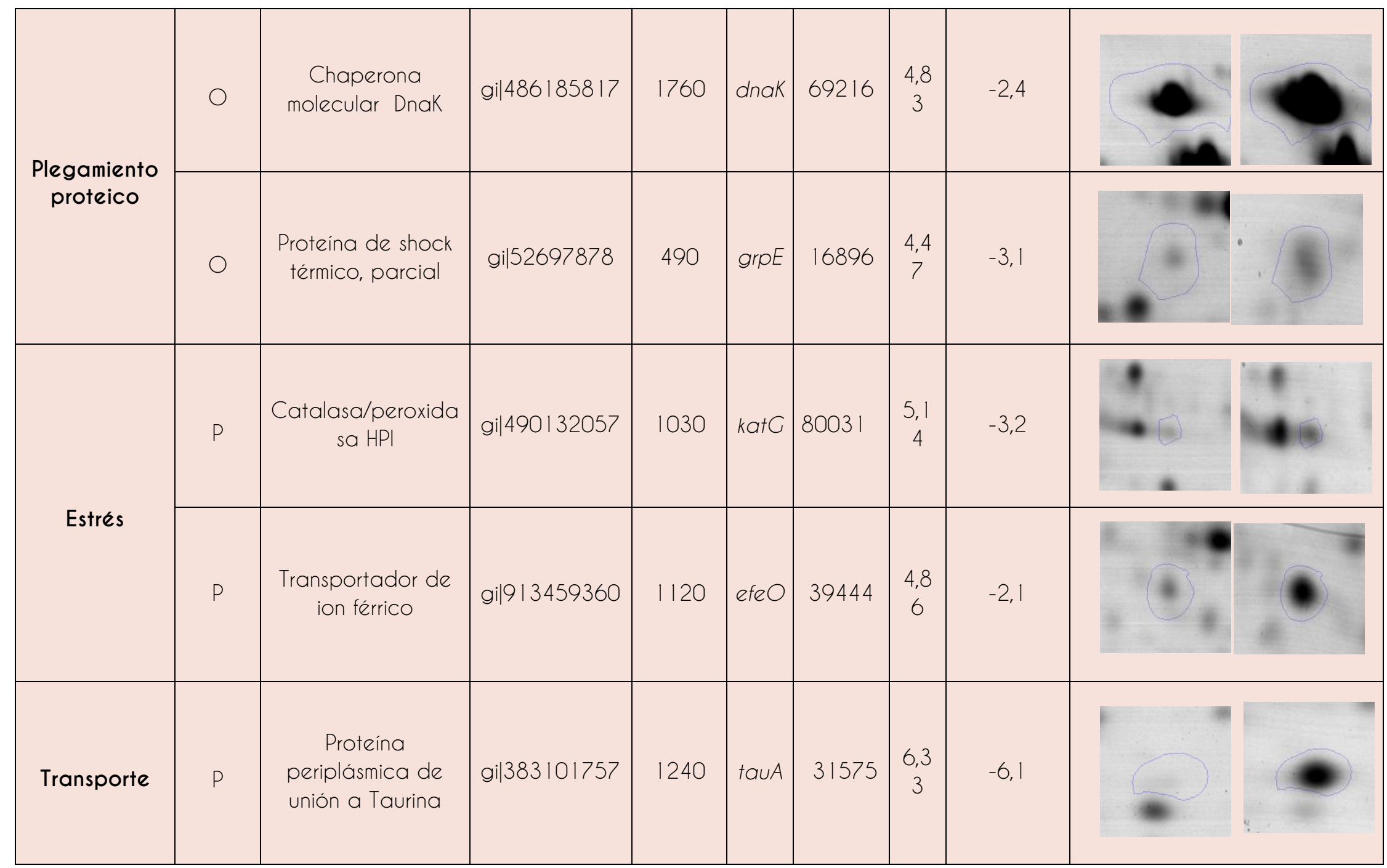




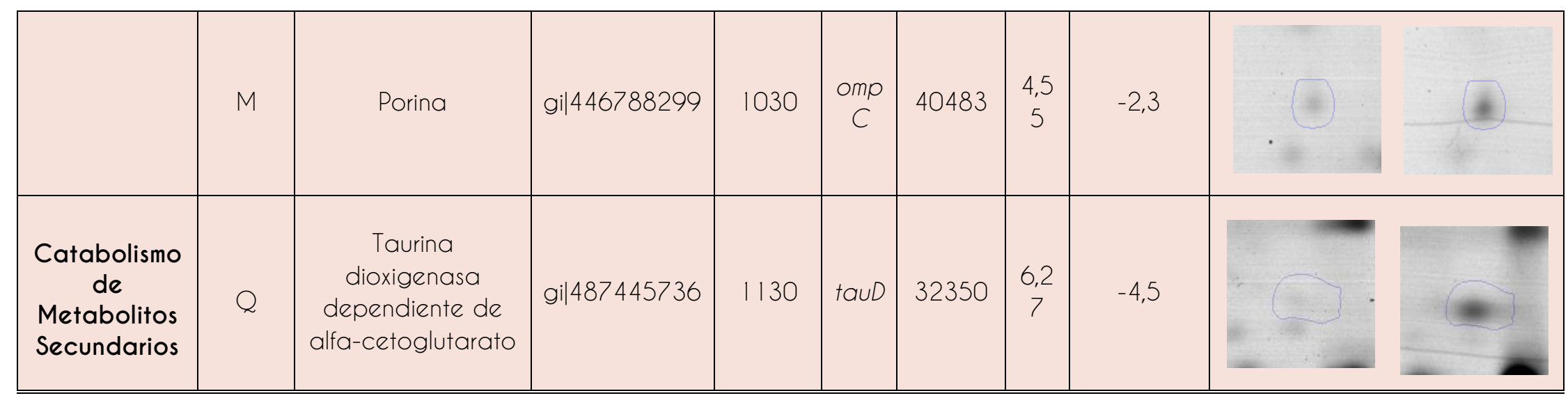

${ }^{*} T 1$ : 6 h de incubación, tanto en cocultivo como cultivo individual.

T2: 30 h de incubación en cocultivo, y 96 h de incubación en cultivo individual

a Categoría funcional según la base de datos COC. Abreviaturas de una letra para las categorías funcionales COC: C: metabolismo y transporte de carbohidratos; C: producción y conversión de energía; K: transcripción; D: división celular y partición cromosómica; l: metabolismo lipídico; Q: biosíntesis, transporte y catabolismo de metabolitos secundarios; R: solo predicción funcional general; M: estructura de la pared celular y biogénesis de membrana externa; E: transporte y metabolismo de aminoácidos; O: chaperonas moleculares y funciones relacionadas;

$\mathrm{J}$ : traducción, incluyendo estructura de ribosomas y biogénesis; S: sin predicción funcional.

b Número de acceso en la base de datos NCBI.

c El score de proteína es - $10^{*}$ Registro (P), donde P es la probabilidad de que la coincidencia observada sea un evento aleatorio. Las puntuaciones de proteína mayores a 81 se consideran significativas $(P<0.05)$.

d Masa Molecular (Da).

e Punto isoeléctrico calculado.

fVeces de expresión: Volúmenes normalizados de spot en cocultivo / Volúmenes normalizados spot en crecimiento individual. 
Tabla 3.5. Proteínas expresadas diferencialmente por ECEH durante su crecimiento en cocultivo con Ent. mundtii a T2 con respecto a su crecimiento en cocultivo a $\mathrm{Tl}$ en $\mathrm{SCM}$ a $30^{\circ} \mathrm{C}$.

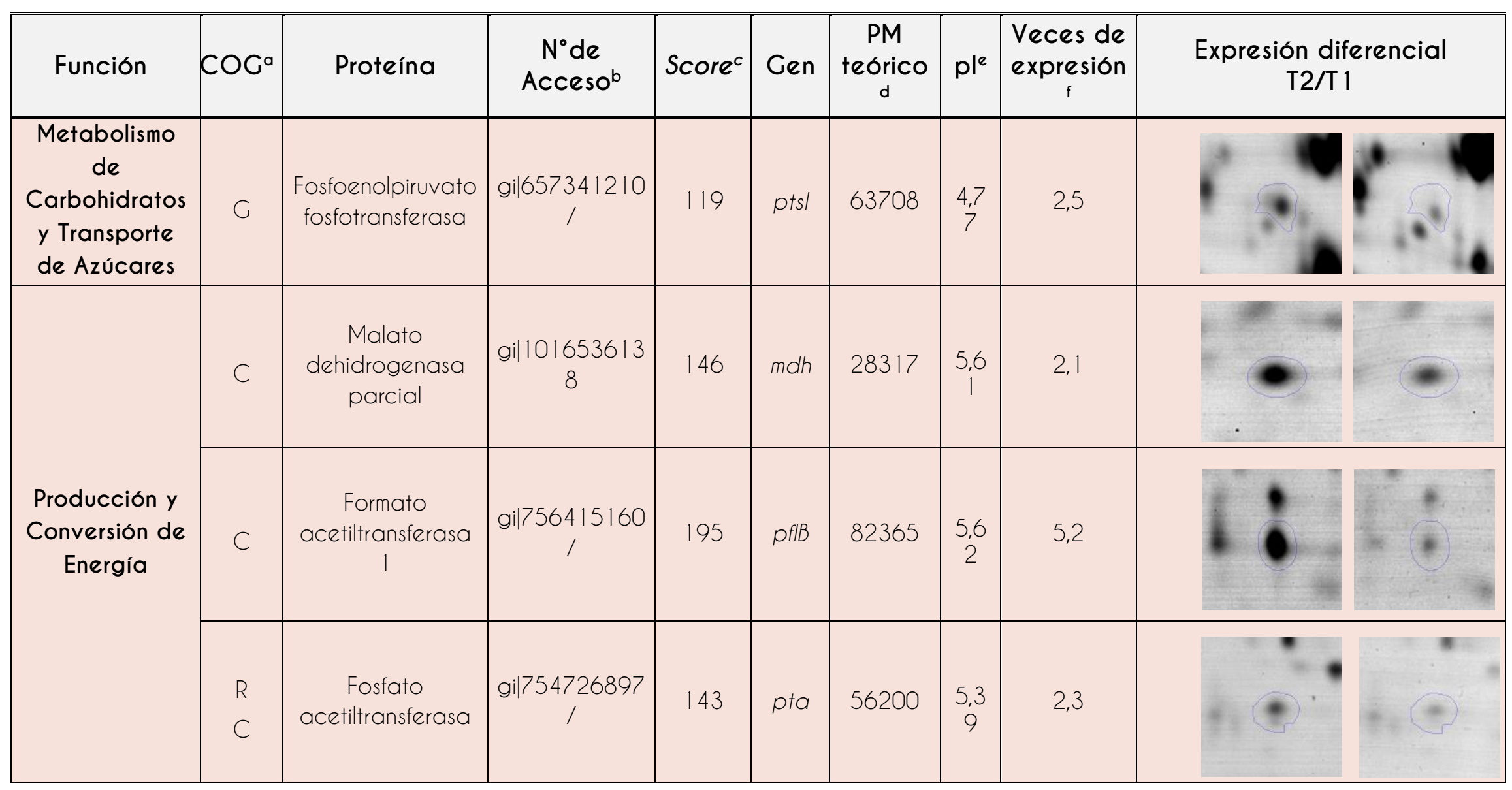




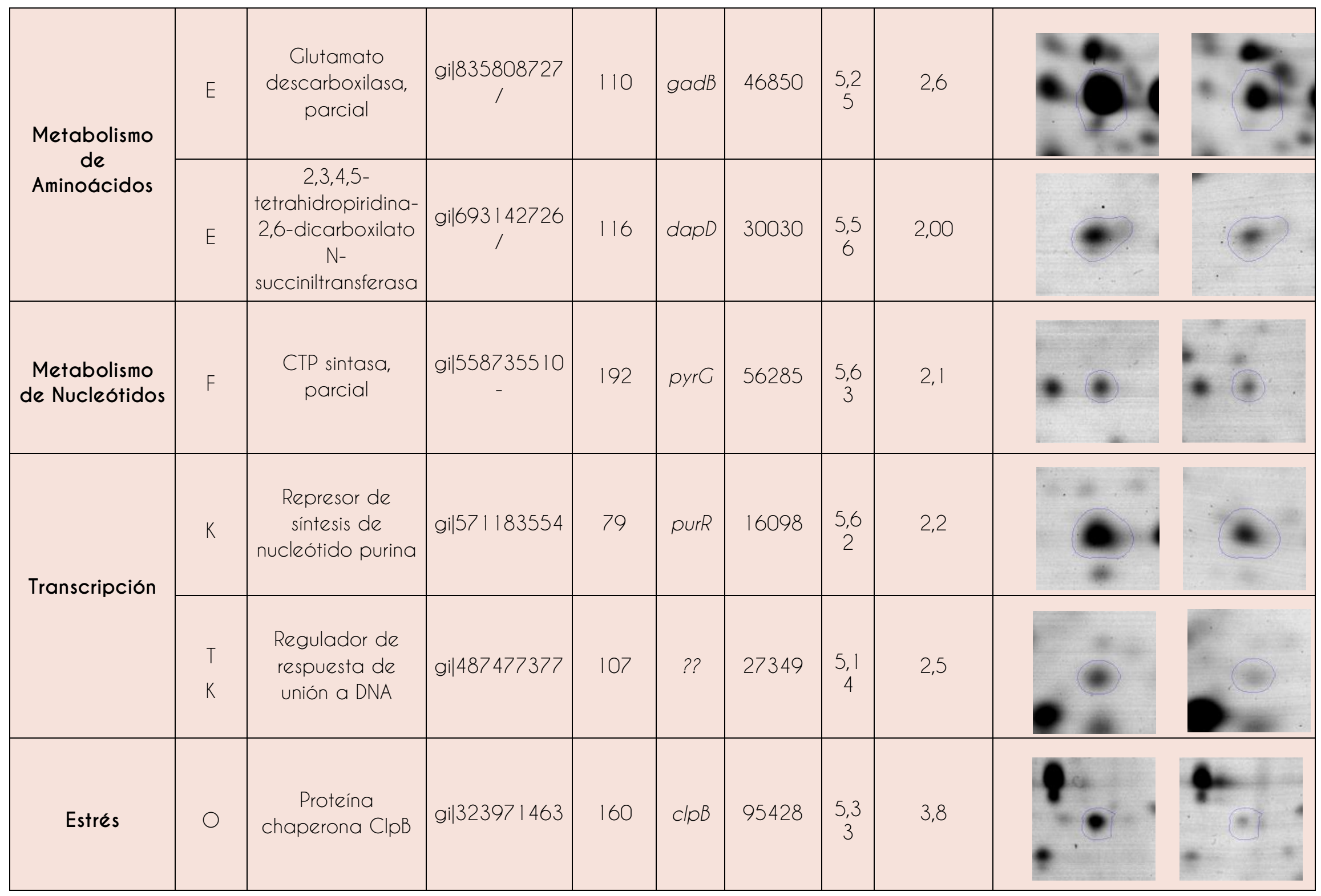




\begin{tabular}{|c|c|c|c|c|c|c|c|c|c|c|}
\hline & $\bigcirc$ & $\begin{array}{c}\text { Chaperona } \\
\text { molecular HtpC, } \\
\text { parcial }\end{array}$ & gi|692193109 & 98 & $h+p C$ & 65179 & $\begin{array}{c}5,0 \\
9\end{array}$ & 2,9 & $e^{2}$ & 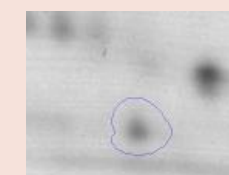 \\
\hline & $P$ & Catalasa HPI & gi| | 46535 & 128 & katC & 80017 & $\begin{array}{c}5,1 \\
4\end{array}$ & 2,4 & 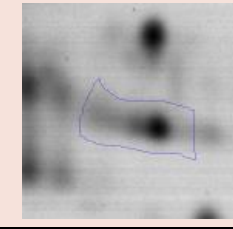 & $+\sqrt{0}+4$ \\
\hline $\begin{array}{l}\text { Biosíntesis de } \\
\text { pared celular }\end{array}$ & $P$ & $\begin{array}{l}\text { Proteína de } \\
\text { biosíntesis de } \\
\text { glucanos } 0\end{array}$ & gil806456002 & 141 & $\begin{array}{c}\text { mdo } \\
G\end{array}$ & 58646 & $\begin{array}{c}6,7 \\
0\end{array}$ & 1,9 & 6 & e. \\
\hline
\end{tabular}

${ }^{*}$ T1: 6 h de incubación en cocultivo.

T2: 30 h de incubación en cocultivo.

a Categoría funcional según la base de datos COC. Abreviaturas de una letra para las categorías funcionales COC: G: metabolismo y transporte de carbohidratos; C: producción y conversión de energía; K: transcripción; D: división celular y partición cromosómica; l: metabolismo lipídico; Q: biosíntesis, transporte y catabolismo de metabolitos secundarios; R: solo predicción funcional general; M: estructura de la pared celular y biogénesis de membrana externa; E: transporte y metabolismo de aminoácidos; O: chaperonas moleculares y funciones relacionadas; J: traducción, incluyendo estructura de ribosomas y biogénesis; S: sin predicción funcional.

b Número de acceso en la base de datos NCBI.

c El score de proteína es -10 * Registro (P), donde P es la probabilidad de que la coincidencia observada sea un evento aleatorio. Las puntuaciones de proteína mayores a 81 se consideran significativas $(P<0.05)$.

a Masa Molecular (Da).

e Punto isoeléctrico calculado.

f Veces de expresión: Volúmenes normalizados de spot en cocultivo T2/ Volúmenes normalizados spot en cocultivo Tl. 


\section{Estudios de adhesión a proteínas de la matriz extracelular cárnica (MEC)}

\section{Resultados}

La colonización exitosa y el establecimiento de un microorganismo en la matriz alimentaria es una consecuencia directa de la adhesión bacteriana efectiva a los principales componentes de la matriz extracelular (Chagnot y col., 2013). La MEC presente entre las fibras musculares, se compone de dos clases principales de macromoléculas, las proteínas fibrosas y los proteoglicanos. Las proteínas fibrosas son los componentes predominantes de la MEC bovina, que comprenden esencialmente colágeno I, III y IV, fibronectina insoluble (i-fibronectina), laminina-a2 y elastina las cuales son los principales agentes de interacción durante la adhesión de los microorganismos a la carne (Chagnot y col., 2013). Por ello consideramos de gran importancia conocer el comportamiento de ambas cepas bacterianas en estudio frente a componentes claves de la matriz extracelular cárnica, tanto en su capacidad individual de adhesión como la influencia recíproca entre ambos microorganismos frente a este fenómeno.

Con este fin se realizó un ensayo en microplaca utilizando como sustratos colágeno IV y laminina. Se permitió la adhesión de forma individual y conjunta en iguales proporciones de Ent. mundtii CRL35 y ECEH a la superficie de la microplaca previamente tapizada con las proteínas de MEC. Luego de eliminar las células que no lograron su adhesión, aquellas células adheridas exitosamente fueron removidas y plaquedas en los medios agarizados correspondientes. El recuento bacteriano obtenido en cada condición representó el porcentaje de células adheridas con respecto al total de células colocadas.

Los resultados obtenidos, que se presentan en la Figura 3.8, demostraron que Ent. mundtii presentó muy buena capacidad de adhesión a ambas proteínas de MEC, observándose que más del 80\% de las células agregadas lograron una óptima adhesión. Además, esta capacidad de adhesión no se vio afectada cuando Ent. mundtii se encontraba en presencia del patógeno, incluso su adhesión a laminina experimentó un incremento del 5\%. Por su parte, ECEH, también demostró buena capacidad de adhesión a ambas proteínas de matriz extracelular (alrededor del 70\% de las células agregadas) aunque menor a la experimentada por Ent. mundtii. Sin embargo, el patógeno no pudo conservar la misma capacidad de adhesión en 
presencia de la BL, sino que, se evidenció una disminución en su capacidad de adhesión cuando se encontraba en presencia de Ent. mundtii, alcanzando tan solo un 54\% de adhesión con respecto a las células colocadas (Figura 3.8).

La capacidad de adhesión diferencial observada de las cepas en estudio a las proteínas de la MEC sugiere que existe una ventaja competitiva de Ent. mundtii sobre el fenómeno de adhesión/colonización del alimento en presencia del patógeno.

120,0
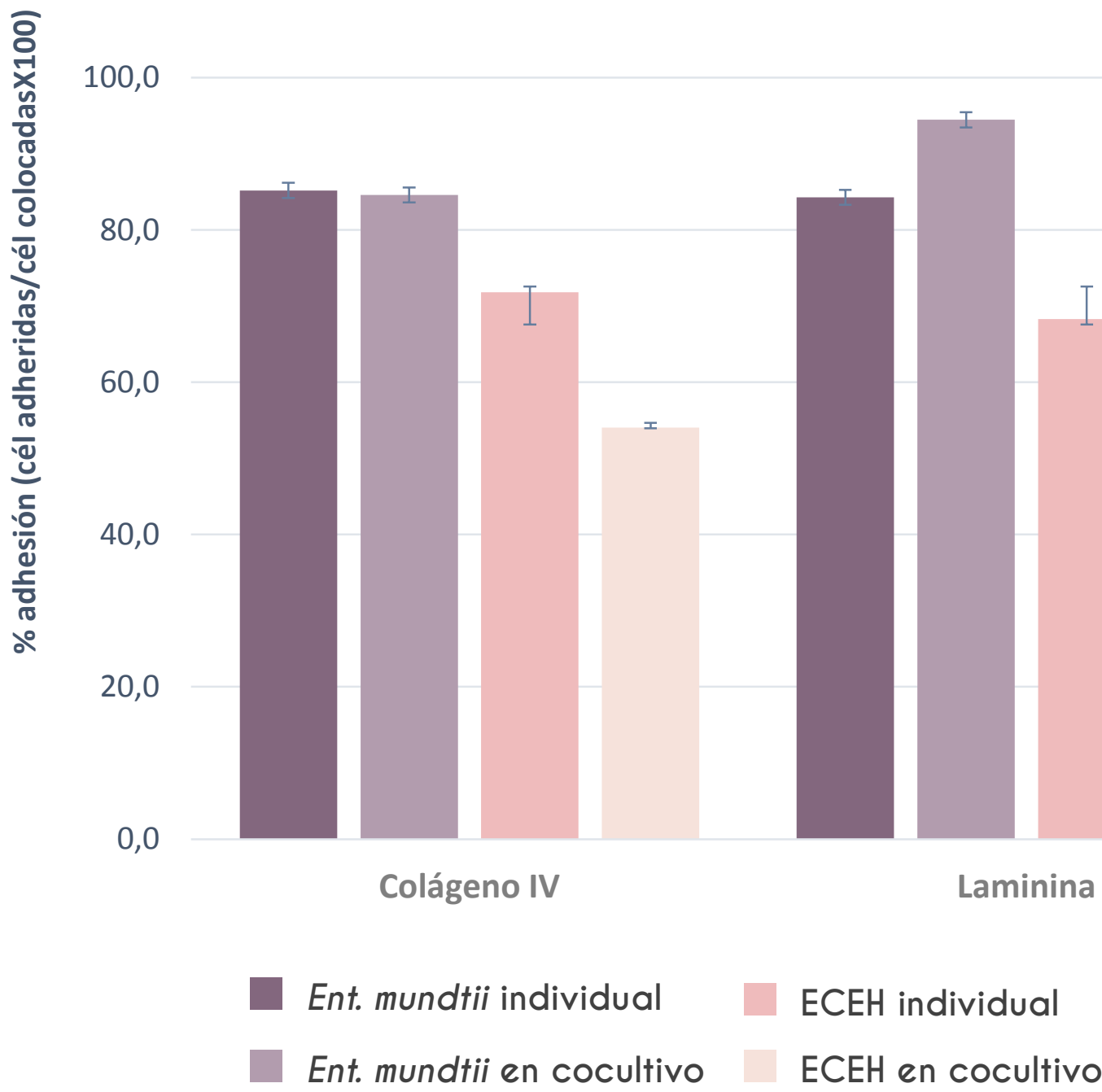

Figura 3.8. Capacidad de adhesión a Colágeno IV y Laminina de Ent. mundtii CRL35 y ECEH agregadas como cultivos individuales o mixtos (BL-ECEH). El nivel de adhesión se expresó en porcentaje teniendo en cuenta el número de células adheridas/número células colocadas $x$ 100. 


\section{Discusión}

La adhesión bacteriana a superficies bióticas es un complejo proceso basado inicialmente en interacciones físicas no específicas entre las dos superficies participantes, que posteriormente dan lugar a interacciones de tipo específicas entre las proteínas de adhesión bacteriana y sus receptores (Yadav y col., 2015). Este último evento es cepa dependiente y la temperatura juega un papel muy importante en el proceso de unión (Zulfakar y col., 2012).

Se encuentra bien establecido, que la capacidad de un microorganismo patógeno para adherirse a las superficies de los alimentos puede influir directamente en su persistencia durante la etapa de fabricación así como también durante el comercio minorista y por ende en su capacidad para ocasionar infecciones (Rivas y col., 2006a). Estudios previos han demostrado que especies bacterianas como Salmonella y E. coli $\mathrm{O}$ 157: H7 se adhieren preferentemente a componentes del tejido conectivo, como las fibras de colágeno (Frank, 2001). De hecho, nuestros estudios confirmaron la capacidad de este patógeno para adherirse a colágeno IV y laminina de forma efectiva. Sin embargo se pudo observar también que la presencia de Ent. mundtii logró reducir su capacidad de unión a las proteínas de MEC estudiadas. Jin y col. (2000) describieron un efecto similar al utilizar la cepa Ent. faecium 18C23, la cual inhibió eficazmente la adhesión de E. coli K88ac y K88MB al moco intestinal de cerdos.

El efecto observado en este estudio, donde Ent. mundtii CRL35 afecta la capacidad de adhesión de ECEH, cobra gran importancia si consideramos que se ha demostrado que la fuerza de unión de un microorganismo a las superficies de la carne interfiere en los procesos de eliminación física y química utilizados contra el patógeno (Benedict y col., 1990; Fratamico y col., 1996; Tamblyn y Conner, 1997). Es decir, las diferentes estrategias aplicadas para la remoción del patógeno serán más efectivas cuanto menor sea la fuerza con la cual éste se encuentre unido a los componentes de la MEC.

Por su parte, Ent. mundtii, demostró óptima capacidad de unión a colágeno IV y laminina. Además, la presencia del patógeno no modificó dicha capacidad de unión, por el contrario, la unión a laminina mostró un incremento en presencia de ECEH. En este sentido, estudios previos indican que la proteína AceA media la unión de E. faecalis OCIRF a colágeno tipo IV, tipo I y laminina (Nallapareddy y col., 2000). 
Estos resultados sugieren que Ent. mundtii desarrolla frente al patógeno un comportamiento de competencia efectiva siendo el proceso de adhesión una de las herramientas utilizadas por la cepa láctica para establecer una concreta ventaja competitiva en su coexistencia con el patógeno. Apoyando esta tendencia, cabe destacar, que en los resultados de los estudios proteómicos, Ent. mundtii sobreexpresó en presencia de ECEH la proteína multifunción enolasa. Esta proteína fue descripta por Peng y col. (2014) como una proteína de unión a actina en Ent. faecalis lo que estaría indicando una estrategia de competencia adicional durante la adhesión a la carne.

Todo lo expuesto refleja la importancia de comprender el proceso de unión bacteriana a proteínas de la matriz alimentaria, para el desarrollo de intervenciones que interrumpan la colonización del alimento, contribuyendo así a reducir la contaminación y aumentar también la efectividad de las estrategias utilizadas contra el patógeno.

\section{Efecto de Ent. mundtii CRL35 sobre la inducción del fago U933}

\section{Resultados}

A través de este ensayo se buscó conocer si el microambiente de competencia y estrés generado por la convivencia e interacción de ECEH con Ent. mundtii CRL35 podría funcionar como un agente inductor del fago W933 que codifica para la toxina Stxl y en consecuencia inducir la producción y liberación de la misma, lo cual constituiría un factor negativo al momento de usar esta BL como bioprotector en el alimento cárnico.

Para ello fue necesario contar con una cepa portadora del fago ya que el modelo utilizado hasta el momento, E. coli NCTC12900, es una cepa carente de

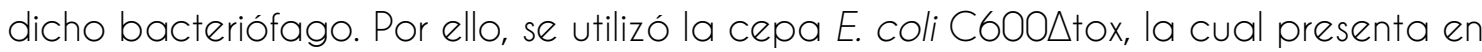
su genoma la incorporación del fago W933 mediante recombinación homóloga (Camage y col., 2003). En dicho fago incorporado el gen stx fue reemplazado por el gen gfp (Green Fluorescent Protein), y por lo tanto, no expresa la toxina, permitiéndonos estudiar el fenómeno de inducción sin asumir riesgos de bioseguridad.

Se monitoré el proceso de inducción mediante la cuantificación del descenso de viabilidad (recuento de UFC/ml) producto de la lisis, como también la cuantificación de las partículas virales (recuento de ufp/ml) liberadas al 
sobrenadante de cultivo luego del contacto con el potencial agente inductor. Ambos parámetros fueron evaluados durante las primeras 24 horas de contacto de E. coli C600 4 tox con Ent. mundtii CRL35.

En la Figura 3.9 se observa el crecimiento de E. coli C6004tox en forma individual, presentando una fase exponencial de crecimiento de aproximadamente 5 a 6 h, ingresando luego a su fase estacionaria manteniendo la viabilidad en aproximadamente 8,5 log UFC/ml hasta el final del tiempo de incubación. Por el contrario, cuando se agregó ciprofloxacina, un antibiótico con conocida capacidad de inducir el ciclo lítico del fago y por ende la producción de toxina en

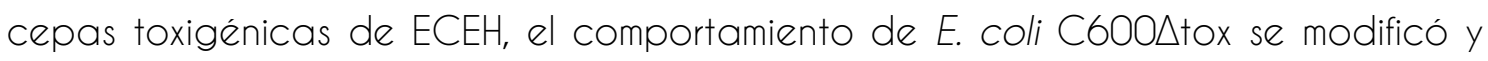
lvego de 3 h de crecimiento exponencial, se produjo un descenso abrupto de viabilidad registrándose una caída de aproximadamente 3 órdenes logarítmicos. Al evaluar el crecimiento de E. coli C6004tox en presencia de Ent. mundtii, observamos que presenta la misma tendencia que aquella observada durante su crecimiento individual, no registrándose caídas en la viabilidad durante todo el periodo evaluado (Figura 3.9).

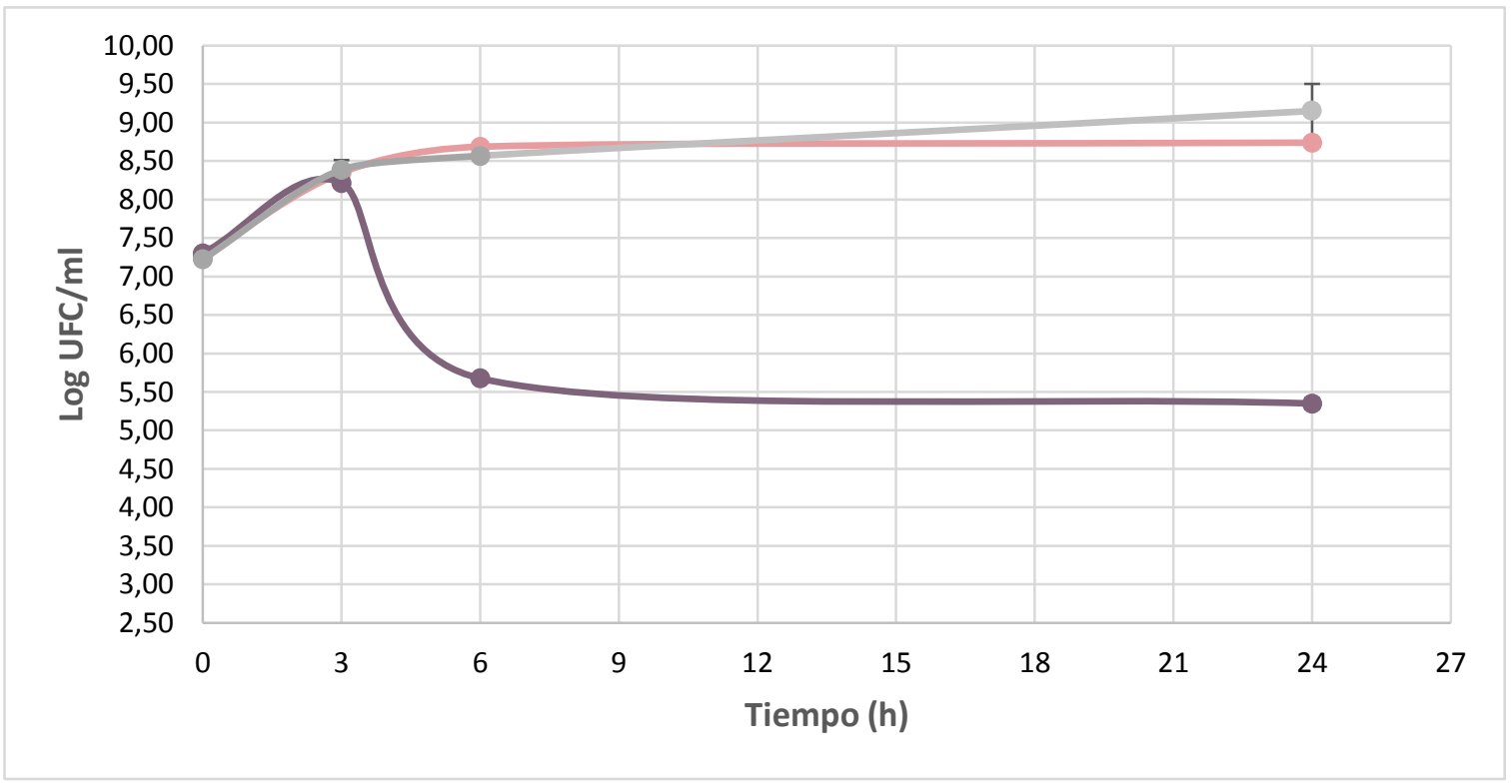

Figura 3.9. Crecimiento determinado mediante recuento de colonias de E. coli C600 4 tox en $L B$ a $37^{\circ} \mathrm{C}$ de forma individual (línea rosa), en presencia de ciprofloxacina (ATB) (línea violeta) y en presencia de Ent. mundtii (línea gris).

Con el fin de evidenciar el proceso de inducción en las diferentes condiciones estudiadas, se llevó a cabo la titulación del fago en el sobrenadante de cultivo 
lvego de 4 h de incubación para las diferentes condiciones estudiadas. También se analizó la concentración del fago a las 24 h para descartar un efecto inductor tardío de la BL

Según los resultados obtenidos no se detectaron partículas virales en aquellos sobrenadantes provenientes del crecimiento de E. coli C600 4 tox en forma individual y tampoco en presencia de Ent. mundtii CRL35 en ambos tiempos estudiados. Sin embargo, en los sobrenadantes provenientes del crecimiento de E. coli C600 6 tox con ciprofloxacina, se obtuvieron placas de lisis para ambos tiempos estudiados como se muestra en la Tabla 3.6.

Tabla 3.6. Titulación del fago W933 mediante el recuento de placas de lisis presentes en el sobrenadante de cultivo de E. coli C600 $\Delta$ tox cuando se cultivó sola (control), en presencia del antibiótico o de Ent. mundtii CRL35, luego de 4 y 24 h de incubación a $30^{\circ} \mathrm{C}$.

\begin{tabular}{cccc}
\hline Tratamiento/Tiempo & Control & $\begin{array}{c}\text { Ciprofloxacina } \\
60 \mathrm{ng} / \mathrm{ml}\end{array}$ & $\begin{array}{c}\text { Ent. mundtii } \\
\text { CRL35 (10 } \\
\text { UFC/ml) }\end{array}$ \\
\hline T4 & nd & $6,7 \mathrm{Log}$ UFP/ml & nd \\
\hline T24 & nd & $7 \mathrm{Log} \mathrm{UFP} / \mathrm{ml}$ & $\mathrm{nd}$ \\
\hline
\end{tabular}

nd: no detectado

Los resultados de este ensayo indican que la BL en estudio no activa el fenómeno de inducción del fago W933, es decir, que el efecto anti ECEH observado no sería acompañado por lisis y producción de toxina. Aunque estos ensayos deberán extrapolarse a escenario real, a partir de estos resultados se avizora el uso seguro de este cultivo bioprotector para la conservación de carnes frescas.

\section{Discusión}

Como se expuso anteriormente, la presencia de Ent. mundtii en SCM ejerce sobre el patógeno un efecto inhibidor que se ve reflejado en el descenso de su viabilidad. Sin embargo, resultaba necesario conocer si el efecto ejercido por Ent. mundtii era acompañado por la inducción del bacteriófago U933 que codifica las toxinas tipo shiga, es decir, si Ent. mundtii CRL35 funcionaba como un agente inductor de ese fago lisogénico. 
Nuestros resultados indicaron que Ent. mundtii no ejerció un efecto inductor sobre E. coli C600 4 tox, es decir no habría expresión y liberación de la toxina ni de partículas virales en presencia de la cepa láctica.

Estos hallazgos revisten gran importancia si consideramos que existen antecedentes que indican que ECEH tiene el potencial de producir toxina Shiga en los alimentos, y que la exposición a estas toxinas es generalmente a través del consumo de carnes rojas contaminadas, leche y sus productos derivados (Rangel y col., 2005). Weeratna y Doyle (1991) han demostrado que la inoculación de ECEH en alimentos produce altos niveles de la toxina en leche (306 ng / ml) y carne (452 $\mathrm{ng} / \mathrm{ml}$ ).

Además, se registraron brotes de SUH donde no se hallaron bacterias vivas en las muestras de alimentos (Coh y col., 2002), indicando que en ese contexto sería la toxina el agente desencadenante del brote. Respaldando esta idea, Rasooly y Do (2010), demostraron que la toxina Shiga 2 (Stx2) es estable al calor y que la pasteurización de la leche no reduciría la actividad biológica de Stx2. Por su parte, Robinson y col. (2006) hallaron que Stx no solo es capaz de afectar al hospedador a través de su unión a receptores Gb3 y posterior acción inhibitoria en la síntesis de proteínas, sino también que es capaz de incrementar la capacidad de EHEC para adherirse a las células epiteliales y colonizar los intestinos en ratones. Esto se produciría por estimulación en la expresión de nucleolina en la superficie celular, un receptor eucariótico para la intimina (principal proteína de ECEH que permite su adhesión al epitelio intestinal). Este aspecto agrava aún más la presencia de la toxina en alimentos.

Si bien el estudio de este fenómeno requiere estudios más exhaustivos y en escenario real, los resultados obtenidos avizoran el uso seguro de Ent. mundtii CRL35 como estrategia bioprotectora contra ECEH, sin contribuir a la producción de Stx en la matriz alimentaria. 


\section{Evaluación de la actividad antilisteria de Ent. mundtii CRL35 durante el cocultivo con ECEH en ambiente cárnico}

\section{Resultados}

Se evaluó la producción de enterocina CRL35 por Ent. mundtii a lo largo del tiempo ( $T 1$ y T2), durante su crecimiento individual y en cocultivo en el sistema cárnico modelo a $30^{\circ} \mathrm{C}$. Esto se llevó a cabo enfrentando un césped del microorganismo indicador Listeria monocytogenes a diferentes diluciones del sobrenadante del cultivo correspondiente, evidenciándose actividad antimicrobiana a través de la formación de un halo de inhibición del crecimiento.

En la Figura 3.10 puede observarse que el título de la enterocina CRL35 detectada en el SCM aumenta en valores absolutos a través del tiempo, tanto cuando la BL crece de forma individual como en cocultivo con el patógeno. Aunque se debe destacar que la producción de bacteriocina es de menor magnitud cuando Ent. mundtii se encuentra en cocultivo con ECEH lo que estaría relacionado con la menor concentración celular alcanzada por la BL en presencia de ECEH a ambos tiempos evaluados, estos valores reflejan una considerable producción aún en presencia del patógeno (> 1000 UA/ml) (Figura 3. 10). Por lo tanto podemos decir que a pesar de producir menores títulos, Ent. mundtii conserva su capacidad de producir enterocina CRL35 en medio cárnico cuando crece con ECEH.

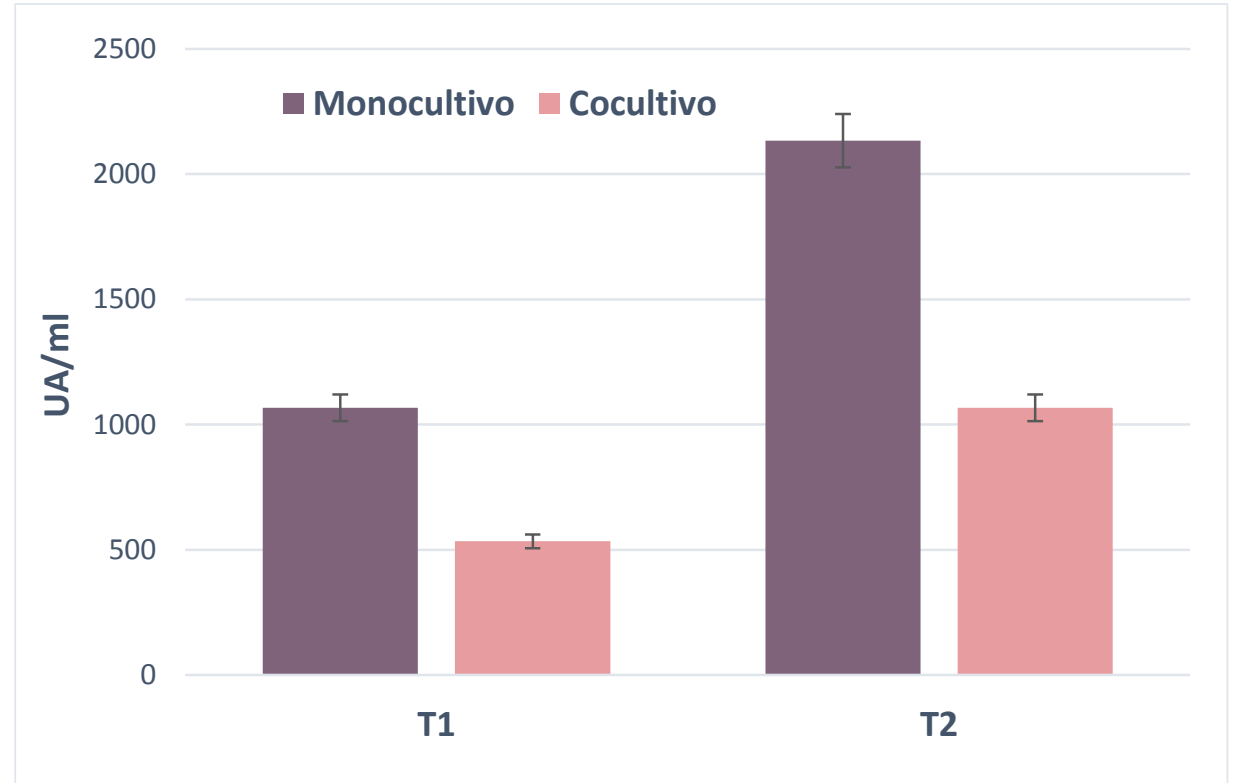

Figura 3.10. Título de enterocina CRL35 producida por Ent. mundtii CRL35 cuando crece de forma individual (barras violetas) y en cocultivo (barras rosas) a Tl (6 h) y T2 (30 h) en SCM a $30^{\circ} \mathrm{C}$. 


\section{Discusión}

Las bacteriocinas producidas por bacterias lácticas han sido ampliamente estudiadas en los últimos años. Las mismas son activas frente a microorganismos Gram positivos filogenéticamente relacionados, mientras que aquellos microorganismos de deterioro y/o patógenos Gram negativos presentan resistencia intrínseca a éstos péptidos antimicrobianos. Reafirmando este concepto, nuestros estudios describieron un efecto inhibitorio de Ent. mundtii sobre ECEH no relacionado con la presencia de su bacteriocina (ver Ensayo de inhibición en placa, Capítulo 2). Sin embargo, desde el punto de vista tecnológico, la producción de enterocina CRL35 por Ent. mundtil en el ambiente cárnico estudiado sería de gran importancia ya que la misma es activa frente a Listeria monocyłogenes, otro patógeno alimentario de gran preocupación para la industria nacional.

Por ello, con el objetivo de conocer la capacidad de Ent. mundtii de producir su bacteriocina específica en presencia de ECEH en el sistema cárnico estudiado (SCM), se llevó a cabo la titulación de dicho péptido en diferentes momentos (TI y T2). Consolidando estudios previos de nuestro grupo, (Orihuel y col., 2018) se demostró que Ent. mundtii fue capaz de producir la enterocina CRL35 en el sistema cárnico modelo, incrementando su producción en valores absolutos a través del tiempo de incubación cuando creció individualmente. Por otro lado, si bien la presencia de ECEH actuó en detrimento de esta producción, registrándose descenso del título en presencia del patógeno, es de destacar que Ent. mundtii no perdió esta capacidad de forma completa.

La potencialidad para producir enterocina CRL35 en el sistema cárnico sería un atributo bioprotector adicional que posicionaría a Ent. mundtii CRL35 como una atractiva herramienta bioprotectora con un espectro de acción ampliado, presentando además de su acción comprobada contra ECEH, capacidad inhibitoria antilisteria gracias a la acción de la enterocina CRL35.

Atendiendo las necesidades entorno a la preservación de alimentos y teniendo en cuenta el limitado rango de acción de las bacteriocinas, generalmente restringido a especies filogenéticamente relacionadas con la cepa productora, diversos estudios se encuentran enfocados al desarrollo de estrategias adicionales a fin de ampliar el espectro de acción de estos péptidos antimicrobianos (Acuña y col., 2015). En este sentido, Acuña y col. (2015) demostraron que la bacteriocina hibrida de amplio espectro Ent35-MccV podría inhibir el crecimiento tanto de Listeria 
monocytogenes (Gram positiva) como de E. coli (Gram negativa) en alimentos modelos (leche desnatada y empanadas). Por su parte, Belfiore y col. (2007) demostraron que la permeabilización de la membrana externa de las cepas de $E$. coli con EDTA y lactato de sodio combinado con lactocina 705 / AL705 producida por L. curvatus CRL 705, permitió inhibir el crecimiento de este patógeno. Sin embargo, se sabe que el complejo manosa fosfotransferasa (PTS-manosa) funciona como receptor específico de membrana para bacteriocinas de clase lla, como lo es la enterocina CRL35 (Ramnath y col., 2004). Un análisis filogenético de 86 miembros de la familia PTS-manosa de una amplia gama de géneros bacterianos, agrupa al complejo PTS-manosa en tres grupos principales (grupos I, II y III). Solo los miembros del grupo I podrían servir como receptores para las bacteriocinas de clase lla, y su eficiencia como receptor varía en un patrón directamente relacionado con sus posiciones filogenéticas (Kjos y col., 2009). Por esa razón en particular sumado a su incapacidad para atravesar la membrana externa, éstas bacteriocinas no actúan sobre las bacterias Gram negativas (Chalón y col., 2012).

En resumen, la combinación de la acción antilisteria, dada por la bacteriocina producida por Ent. mundtii CRL35, y su efecto anti ECEH ejercido por mecanismos independientes de bacteriocina, hacen el empleo de esta BL como cultivo bioprotector una estrategia de bioprotección tecnológicamente atractiva. 


\section{INTERACCIONES MICROBIANAS EN CONDICIONES TECNOLÓGICAS}
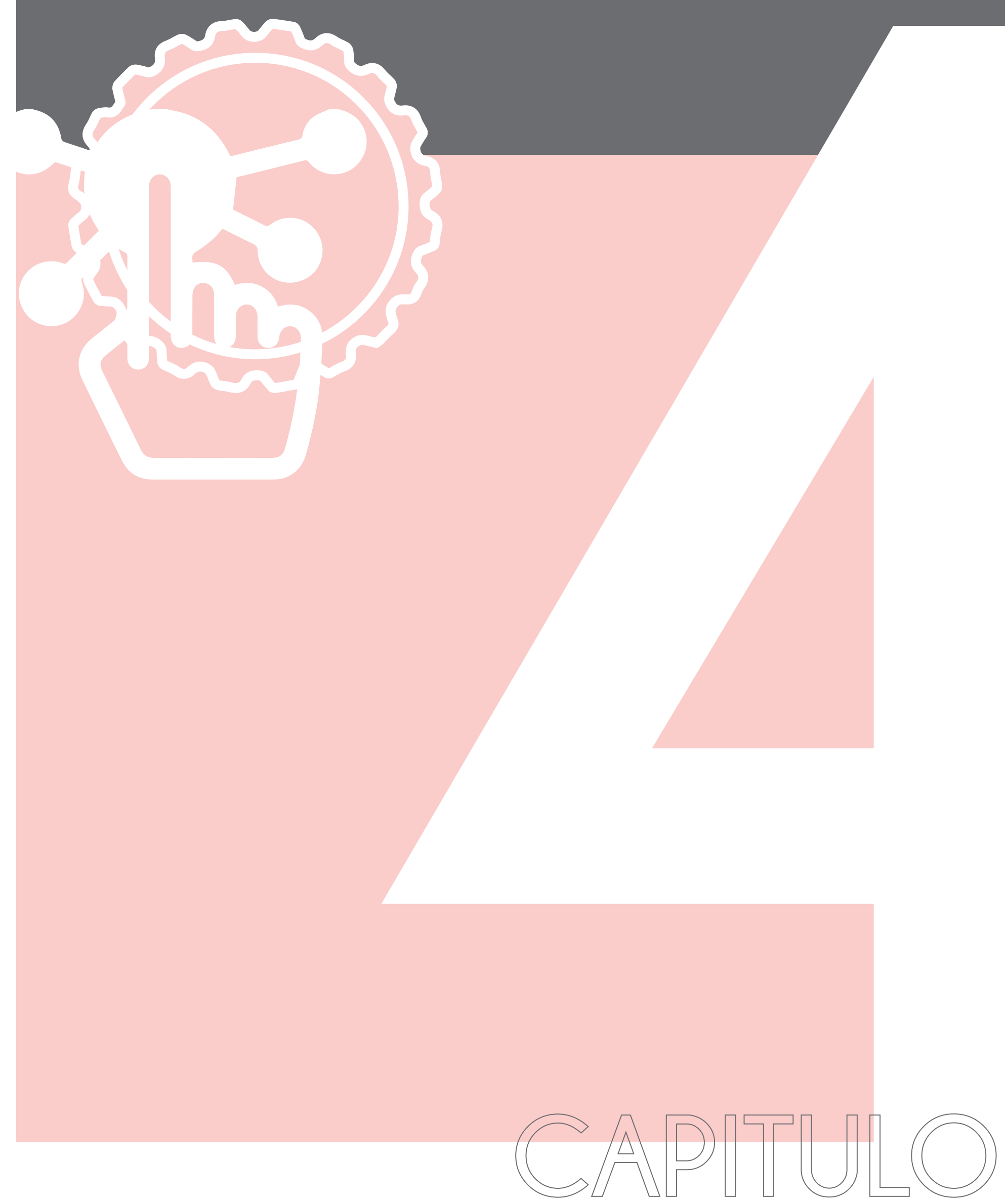


\section{CAPITULO 4 \\ INTERACCIONES MICROBIANAS EN CONDICIONES TECNOLÓGICAS}

\section{Introducción}

Luego de conocer el comportamiento de ambos microorganismos en estudio (Ent. mundtii y ECEH) y su interacción en un sistema cárnico experimental (SCM), y con el objetivo de evaluar la acción bioprotectora de Ent. mundtii CRL35 en escenario real, se diseñó un sistema experimental constituido por carne molida obtenida en condiciones asépticas que nos permitió analizar comparativamente los estudios realizados in vitro. Si bien el SCM utilizado en los ensayos in vitro es una aproximación al ambiente cárnico, encontrándose allí una composición proteica y de carbohidratos similar a la presente en el alimento, las condiciones óptimas de tiempo y temperatura utilizadas hasta ahora, constituyen parámetros permisivos que podrian exacerbar los efectos observados. Por lo tanto, resulta fundamental el estudio de estos eventos en un escenario que reúna las características tecnológicas reales que enfrentarán ambos microorganismos. Con este objetivo, los ensayos previamente realizados in vitro (SCM), fueron extrapolados en un sistema in situ (carne molida) en el cual se disminuyó el tiempo de ensayo de 96 a 48 h que es el tiempo máximo que podría considerarse para la preparación y consumo de la carne molida. Además, se bajó la temperatura de $30^{\circ} \mathrm{C}$ usada en los ensayos in vitro a $16^{\circ} \mathrm{C}$ simulando condiciones de procesamiento y/o ruptura momentánea de la cadena de frio durante el traslado y conservación de la carne. 


\section{Desempeño de Ent. mundtii y ECEH en carne molida: estudios fisiológicos}

\section{Resultados}

Se realizó el crecimiento individual y en cocultivo de ambos microorganismos en el sistema experimental constituido por carne molida. La evaluación de la actividad inhibitoria de la cepa láctica se abordó usando tres aproximaciones diferentes relacionadas con los momentos en los cuales se produciría el enfrentamiento con el microorganismo patógeno y las posibles acciones de Ent. mundtii sobre ECEH en el alimento cárnico:

- Efecto competitivo: bajo la hipótesis de que el patógeno y la BL se enfrentan simultáneamente, por ejemplo, durante el procesamiento de la carne (despiece, troceado y/o molido) con la inmediata aplicación del cultivo bioprotector. Para simular esta situación se inocularon ambos microorganismos simultáneamente.

- Efecto preventivo: bajo el supuesto de que la contaminación de la carne se produce luego de la aplicación del cultivo bioprotector, es decir durante los pasos siguientes del procesamiento, envasado o distribución del producto. Para simular esta situación, se inoculó primero la carne con Ent. mundtii y luego de 6 horas de incubación se contaminó la misma con ECEH.

- Efecto de desplazamiento: bajo el supuesto de que la carne resultó contaminada con ECEH previamente a la aplicación del cultivo bioprotector, por ejemplo, durante la faena y manipulación de las canales incluyendo el despiece y troceado. Para simular estas circunstancias se contaminó primero la carne con ECEH y luego de 6 horas se inoculó la BL.

Cuando se evaluó el desempeño de Ent. mundtii CRL35 en carne molida, se observó que, en los tres desafíos llevados a cabo, la BL logró mantener su viabilidad inicial (7 log UFC/g) durante las 48 h que duró el ensayo, no observándose descenso del pH, el cual se mantuvo constante en valores cercanos a 5,5 durante todo el tiempo evaluado. Ent. mundtii se comportó de manera similar también cuando creció en forma individual en la carne molida. Por ello, en la Figura 4. I A, se encuentra graficado de forma unificada y mostrativa el crecimiento de Ent. mundtii, en carne molida, el cual presentó valores muy similares en todos los lotes estudiados. En base 
a los resultados obtenidos, podemos inferir que, en las condiciones ensayadas, ECEH no influyó en el desarrollo de Ent. mundtii en carne molida.

Por otra parte, cuando se analizó el crecimiento de ECEH como cultivo individual, se observó que este ingresó en fase exponencial luego de 6 h de incubación, mostrando un crecimiento exponencial durante el período evaluado y un incremento en aproximadamente 3,5 log UFC/g a las $48 \mathrm{~h}$ respecto al inoculo inicial (Figura 4. IB, línea amarilla). En el ensayo de desplazamiento, cuando la BL se inoculó luego de 6 h, ECEH tuvo un crecimiento muy similar al presentado durante su incubación en forma individual, de manera que la BL no mostró acción bioprotectora en estas condiciones (Figura 4.1B, línea violeta). Sin embargo, cuando el patógeno creció en cocultivo con Ent. mundtii bajo un efecto preventivo (BL inoculada $6 \mathrm{~h}$ antes que ECEH) o competitivo (ambos microorganismos inoculados en forma simultánea), el patógeno ingresó a su fase exponencial a las 6 h, pero a las $24 \mathrm{~h}$ entró de manera anticipada a fase estacionaria, lo que no se observó en los tratamientos anteriores, alcanzando, luego de 48 h, 2 log UFC/g menos de crecimiento que en ausencia de la BL (Figura 4. IB líneas gris y rosa, respectivamente). De manera que Ent. mundtii CRL35 ejerció un efecto bacteriostático sobre EHEC en carne molida (a $16^{\circ} \mathrm{C}$, 48h) cuando fue inoculada de forma previa $\mathrm{a}$ simultáneamente con el patógeno en la matriz alimentaria. 


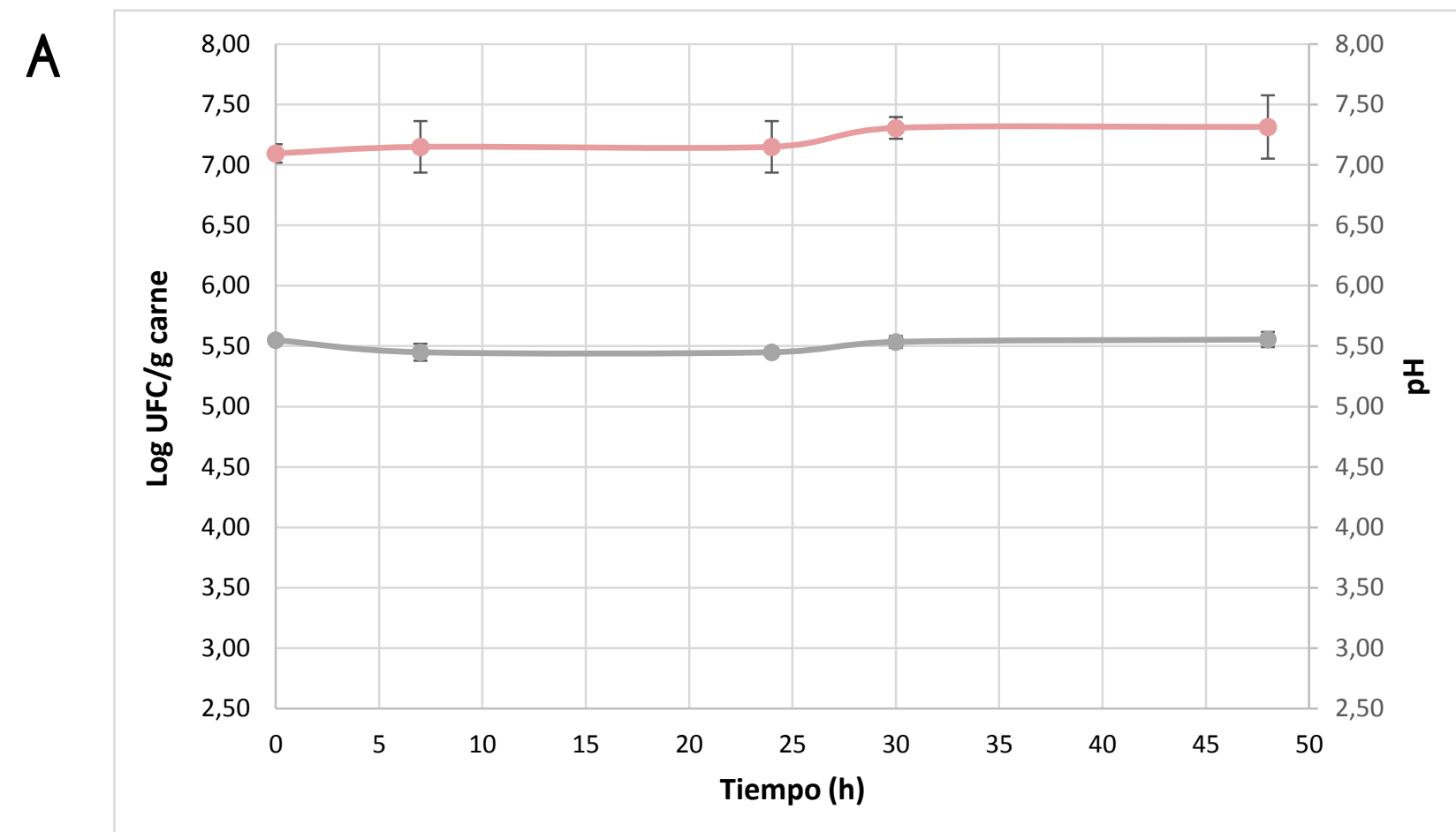

B

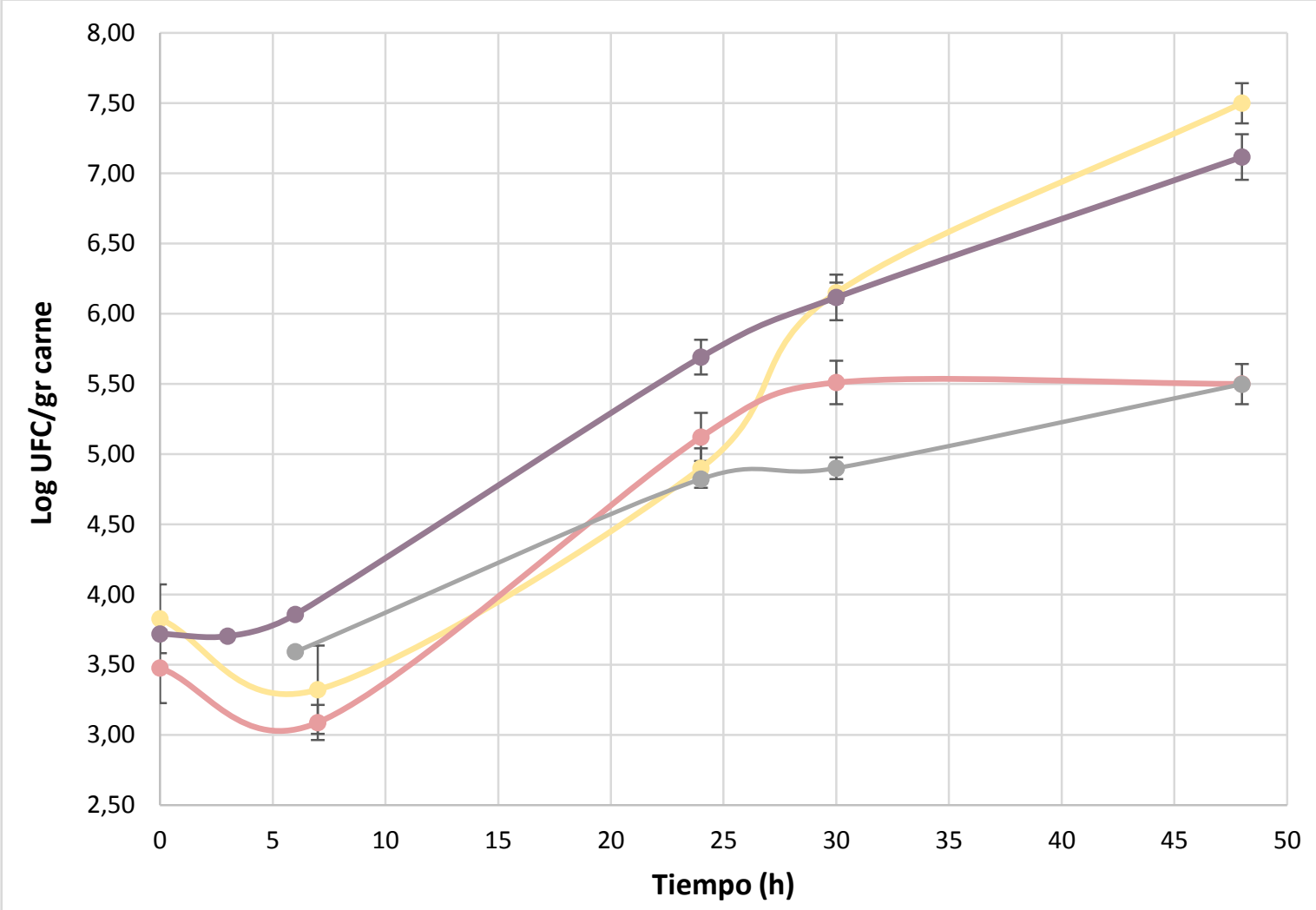

Figura 4.1. (A) Crecimiento de Ent. mundtii CRL35 en carne molida (crecimiento individual y en cocultivo con ECEH) (línea rosa) y pH desarrollado durante la incubación (línea gris). (B) Crecimiento de ECEH en carne molida a $16^{\circ} \mathrm{C}$ durante $48 \mathrm{~h}$ de incubación en forma individual (línea amarilla) y en cocultivo con Ent. mundtii bajo los diferentes efectos evaluados: efecto competitivo (línea rosa), efecto preventivo (línea gris), efecto de desplazamiento (línea violeta). 
Por otro lado, y debido a la importancia que reviste contar con una cepa de amplio espectro de acción, durante esta etapa de estudios in situ, se llevó a cabo la titulación de enterocina CRL35 producida por Ent. mundtii durante su incubación en carne molida tanto de forma individual como en cocultivo. Sin embargo, en estas condiciones, la bacteriocina no pudo detectarse. Estos resultados no descartan la producción del péptido por la cepa láctica en el alimento, sino más bien, reflejan una limitación de la técnica utilizada para su detección, ya que probablemente una fracción significativa del péptido podría estar asociada o adsorbida por la grasa y partículas de la carne con la consiguiente subestimación de la misma (Orihuel y col., 2018). Este obstáculo fue registrado en trabajos anteriores y fue resuelto mediante la valoración de viabilidad del patógeno en la matriz alimentaria (Orihuel y col., 2018). Es por ello que en estas condiciones ensayadas, sería correcto evaluar la actividad antimicrobiana de Ent. mundtii mediante ensayos de viabilidad con la cepa sensible Listeria monocytogenes, objetivo que forma parte de las proyecciones inmediatas de la presente tesis.

Además, se intentaron reproducir los ensayos proteómicos anteriormente concretados en SCM, con el objetivo de conocer si aquél comportamiento descripto mediante el análisis diferencial de proteínas para cada microorganismo in vitro, se presentaba también en condiciones tecnológicas, o bien, evidenciar si en escenario real la expresión de proteínas de los microorganismos en interacción era diferente. Se decidió estudiar el proteoma de ambos microrganismos creciendo de forma individual y en cocultivo (efecto competitivo) luego de 7 y 48 h de incubación. Luego del procesamiento completo de las muestras, éstas fueron enviadas para su análisis e identificación por espectrometría de masas. Sin embargo, los resultados indicaron que las proteínas pertenecientes a los microrganismos en estudio no pudieron identificarse con niveles aceptables de confianza, ya que las mismas se encontraban solapadas por proteínas de origen bovino, ampliamente mayoritarias, que actuaron como un potente interferente en la identificación de proteínas bacterianas. Concretar este ensayo demanda una laboriosa y específica puesta a punto entorno a la técnica de obtención y tratamiento de muestras para eliminar las proteínas cárnicas y enriquecer las de nuestro interés, las del proteoma de ambos microorganismos en estudio, objetivo que forma parte de futuros estudios de nuestro grupo. 


\section{Discusión}

Los ensayos in situ llevados a cabo se diseñaron con el objetivo de aproximar los parámetros de estudio a un escenario real, bajo condiciones de abuso de temperatura, situación ineludible desde un punto de vista pragmático ya que constituye un importante factor que favorece la proliferación y contaminación de la carne con este patógeno a lo largo de la cadena de producción: desde la granja hasta la mesa. También, la temperatura de almacenamiento se considera el factor más importante que rige el deterioro de la carne (Mataragas y col., 2006; Doulgeraki y col., 2012). A pesar que la mayoría de los países cuentan con regulaciones que establecen los límites de temperatura máxima para el almacenamiento refrigerado de la carne, en la práctica, a menudo son excedidos (Koutsoumanis y col., 2006). Estudios previos demostraron que condiciones de temperatura superiores a $10^{\circ} \mathrm{C}$ no son inusuales durante el transporte, almacenamiento por menor y manejo por parte del consumidor (Giannakourou y col., 2001). Atendiendo a estas situaciones se llevaron a cabo los diferentes ensayos en carne molida a una temperatura de incubación de $16^{\circ} \mathrm{C}$ durante $48 \mathrm{~h}$, tiempo más allá del cual se afectarían distintos parámetros relacionados a la calidad sensorial de la carne, lo cual impediría su comercialización.

Estos ensayos evidenciaron que Ent. mundtii CRL35 ejerció un efecto bacteriostático sobre ECEH en carne molida cuando fue inoculada de forma previa (efecto preventivo) o simultáneamente (efecto competitivo) con el patógeno, logrando una reducción concreta de dos unidades log de ECEH. Por su parte, Sparo y col. (2013) al estudiar los mismos efectos en cocultivo (preventivo, competitivo y de desplazamiento) de la cepa Enterococcus faecalis CECT7 121 sobre E. coli O157:H7 en carne molida, obtuvieron también mayor efectividad durante el tratamiento preventivo del patógeno, mientras que el efecto competitivo y de desplazamiento fueron menos eficientes. Sin embargo, en nuestros estudios, los efectos preventivo y competitivo mostraron la misma eficacia contra ECEH; no así la inoculación previa del patógeno, o efecto de desplazamiento, en donde Ent. mundtii no demostró actividad inhibitoria. Desde un punto de vista práctico, estos resultados indicarían la posible utilización del cultivo láctico en aquellas situaciones donde ocurra la inoculación de la BL en el alimento de forma previa o concomitante al patógeno. En este sentido debemos considerar que la calidad microbiológica de la carne es altamente dependiente de la contaminación inicial de las canales (80\%), 
mientras que el resto de la carga contaminante (20\%) surge como resultado esencialmente de la contaminación cruzada durante el curso del procesamiento industrial. Por lo tanto, de acuerdo los resultados obtenidos la acción bioprotectora de Ent. mundtii podría centrarse en prevenir eventos de contaminación cruzada, cuando fuera aplicada en canales de buena calidad microbiológica protegiéndolas de futuras contaminaciones tanto durante las etapas de procesamiento como así también durante la manipulación de la carne desde la góndola hasta antes de su cocción.

Los resultados obtenidos en esta etapa de trabajo evidencian un efecto antagónico de menor magnitud que aquél observado durante los ensayos in vitro. Esto podría relacionarse con la implementación de condiciones de temperatura y tiempo $\left(16^{\circ} \mathrm{C}, 48 \mathrm{~h}\right)$, que difieren a los aplicados durante los estudios in vitro $\left(30^{\circ} \mathrm{C}\right.$, 96 h), siendo éstos últimos capaces de exacerbar los efectos de las interacciones existentes entre ambos microorganismos. Además, cabe destacar que en la utilización de una matriz sólida, como lo es la carne, existe una mayor dificultad de interacción entre ambos microorganismos ya que las propias partículas de carne así como partículas de grasa, ejercen un efecto de tipo estérico que dificulta el íntimo contacto entre microorganismos así como también la difusión de otros compuestos solubles.

Este efecto antagónico exacerbado y previsible cuando se ensayan condiciones in vitro fue descripto también por Smith y col. (2005) cuando estudiaron la capacidad de cuatro cepas lácticas para inhibir E. coli O 157:H7 in vitro (medio de cultivo comercial tripticase soja) a $5^{\circ} \mathrm{C}$, donde obtuvieron una reducción de 3 a 5 log luego de 12 días de almacenamiento, mientras que al reproducir este ensayo en carne molida fresca lograron una reducción de 1,5 log luego del mismo tiempo de incubación.

Cabe destacar, en favor del efecto bioprotector esperado, que la carga microbiana del patógeno encontrada normalmente en alimentos contaminados no supera las 100 cél/gr de carne, número considerablemente menor al utilizado en este estudio. Por lo cual la BL en realidad enfrentaría una carga microbiana de aproximadamente 1,5 a 2 unidades logarítmicas menor en el alimento, lo que significaría un importante factor de competencia favorable para la BL en el ejercicio de su efecto inhibitorio

Asimismo, los resultados obtenidos durante los ensayos in situ, demuestran la necesidad de optimizar los parámetros y estrategias tecnológicas implementadas, a 
fin de potenciar el efecto inhibitorio de la cepa láctica sobre ECEH en el alimento. En este sentido la tecnología de obstáculos, introducida por Leistner, propone implementar obstáculos de acción subletal combinados estratégicamente para conseguir un efecto sinérgico final superior, y al mismo tiempo preservar la calidad del alimento. Sumado a esto, la tendencia actual hacia la aplicación de barreras naturales para la preservación de alimentos es una corriente firme impulsada por las exigencias de los consumidores. Así, diversas plantas y sus aceites esenciales se han evaluado como fuentes naturales para controlar el deterioro de alimentos por microorganismos contaminantes. Skandamis y Nychas (2000) informaron la actividad antibacteriana del aceite esencial de orégano contra E. coli en ensalada de berenjena, mientras que Moghimi y col. (2016) lo hicieron para el aceite esencial de Thymus daenensis (tomillo). Por su parte Zhang y col. (2017) sugieren al aceite esencial de pimienta negra como agente antibacteriano natural contra E. coli para uso en la industria cárnica. Este enfoque realza la posibilidad de utilizar el cultivo bioprotector estudiado, Ent. mundtii CRL35, como obstáculo para la preservación de alimentos cárnicos, donde podría ser estratégicamente combinado y fortalecido con otras tácticas de control de ECEH, constituyendo así, un conjunto de barreras naturales debidamente aplicadas para impedir la sobrevida del patógeno.

Por otro lado, y debido a los resultados favorables obtenidos al evaluar la cepa L. plantarum CRL681, se prevé profundizar los estudios de interacción entre ésta y el patógeno, como así también, el efecto conjunto de ambas cepas lácticas (Ent. mundtii CRL35 y L. plantarum CRL681) contra el desarrollo de ECEH (Baillo, 2018), con el fin de evaluar un posible efecto sinérgico entre ambas y diseñar de esa forma el cultivo bioprotector más eficiente.

En resumen, el abordaje in situ realizado vislumbra la posible utilización de Ent. mundtii como cultivo bioprotector bacteriostático contra ECEH de forma preventiva o competitiva en carne molida; efecto que se espera potenciar ajustando condiciones tecnológicas mediante la combinación con obstáculos adicionales y/o complementando con la acción de otra cepa láctica como L. plantarum CRL68 1, a fin de lograr un efecto contundente sobre el patógeno. 

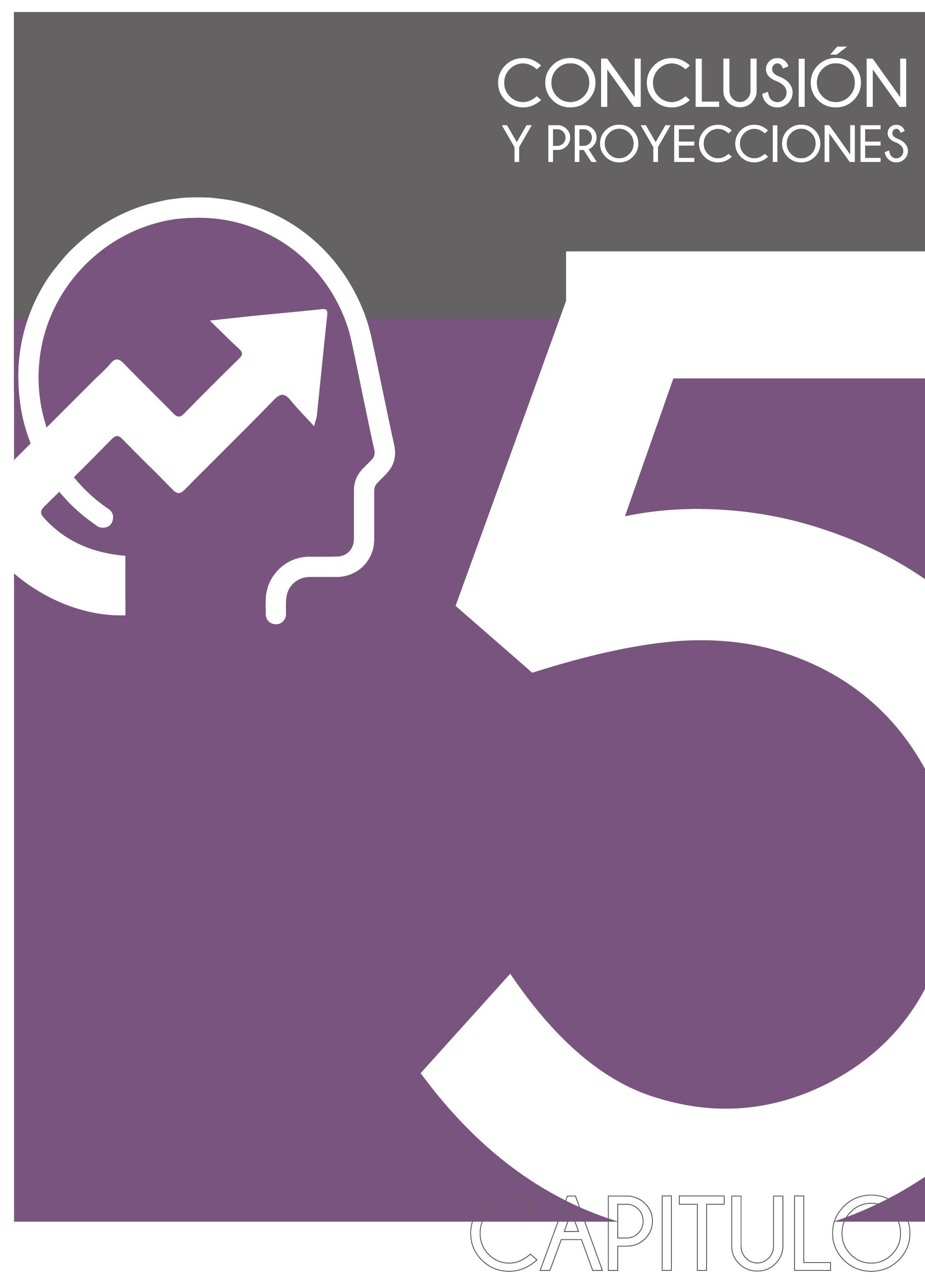


\section{CAPÍTULO 5 CONCLUSIÓN Y PROYECCIONES}

\section{Conclusión}

En este trabajo de tesis doctoral, se abordan por primera vez estudios de interacción entre una BL y un patógeno como E. coli enterohemorrágica constituyendo un importante aporte al conocimiento sobre los mecanismos involucrados en la inhibición llevada a cabo por la BL estudiada sobre este patógeno alimentario. El estudio incluyó estudios bioquímicos, fisiológicos y moleculares in vitro, extrapolando los mismos a la matriz alimentaria (estudios in situ). Parte de los ensayos de interacción se llevaron a cabo gracias al desarrollo y puesta a punto de una nueva metodología que permitió analizar el proteoma de ambos microorganismos durante su interacción en el sistema experimental cárnico. Los resultados obtenidos han demostrado el verdadero potencial inhibidor de Ent. mundtii CRL35 contra un patógeno de gran preocupación como E. coli O 157: H7. Dicha inhibición no se debió a la producción de ácido o bacteriocina sino probablemente a una relación célula-célula más compleja durante la interacción microbiana. Los resultados proteómicos respaldaron las observaciones fisiológicas, demostrando un metabolismo global activo de Ent. mundtii mediante la sobreexpresión de numerosas proteínas metabólicas, permitiéndole mantener su viabilidad y contribuyendo así a la competencia efectiva con ECEH. Por el contrario el patógeno presentó represión proteica generalizada en cocultivo, reflejando un metabolismo abatido frente a la cepa láctica que logró precipitar su ingreso a fase de muerte. Además, la adhesión diferencial a las proteínas de la matriz extracelular cárnica (MEC) sugiere que habría una ventaja competitiva de Ent. mundtii CRL35 sobre EHEC durante la adhesión/colonización del alimento. Asimismo, la cepa láctica demostró ser una alternativa bioprotectora segura ya que no actuaría como agente inductor estimulando la liberación de la toxina shiga. Al analizar el efecto antagónico contra el patógeno en escenario real (estudios in situ), nuestros resultados demostraron tener la misma tendencia que la observada in vitro, evidenciando un efecto de tipo bacteriostático de Ent. mundtii sobre ECEH en las 
condiciones ensayadas en carne molida que requerirán el ajuste tecnológico necesario para su aplicación en la industria.

Los estudios llevados a cabo en esta tesis constituyen un aporte a la tecnología de alimentos cárnicos ya que se propone por primera vez un cultivo láctico bioprotector especifico contra ECEH con demostrada actividad antilisteria, abriendo nuevas perspectivas para la aplicación de BL como estrategia biológica para el control de un patógeno alimentario que demanda soluciones urgentes en nuestro país.

\section{Proyecciones}

Con el fin de profundizar el conocimiento acerca de la interacción BLECEH y con perspectivas de alcanzar el diseño de un cultivo bioprotector efectivo contra el patógeno, se propone, en base a los resultados obtenidos durante este trabajo de tesis doctoral, los siguientes objetivos futuros:

- Considerando los resultados favorables obtenidos al utilizar la cepa L. plantarum CRL681 (Baillo, 2018) se pretende profundizar los estudios de interacción entre ésta y el patógeno, así como también, evaluar el efecto de ambas cepas lácticas (Ent. mundtii CRL35 + L. plantarum CRL681) contra $\mathrm{ECEH}$, con el fin de determinar un posible efecto sinérgico entre ambas y optimizar de esa forma la estrategia bioprotectora a utilizar.

- Desarrollar un análisis proteómico de expresión diferencial en el alimento contaminado y bioprotegido. Esto implica la puesta a punto de la técnica empleada, principalmente en la etapa de recolección de muestra donde será necesario eliminar la interferencia ocasionada por las proteínas de origen bovino. Este análisis nos permitirá conocer el desempeño de ambas cepas estudiadas en el ambiente real.

- Estudiar con mayor profundidad el fenómeno de inducción del fago 933W por la presencia del cultivo bioprotector. Por ello es necesario, poner a punto la detección de la fluorescencia emitida por la proteína CFP codificada por la cepa E. coli C600 6 tox en reemplazo del gen stx. Esto funcionaría como 
una medida indirecta de la expresión de la toxina en presencia de agentes inductores. Asimismo se propone luego llevar a cabo este análisis utilizando una cepa de E. coli O 157:H7 productora de la toxina shiga y evaluando de forma directa la producción de la misma mediante ensayos de ELISA.

- Evaluar la actividad antilisteria de Ent. mundtii CRL35 durante su crecimiento in situ en presencia de ECEH y Listeria monocytogenes mediante el análisis de viabilidad a lo largo del tiempo.

- Reproducir los ensayos fisiológicos desarrollados hasta el momento utilizando una cepa patogénica productora de la toxina, así como también frente a un conjunto de cepas de E. coli O157:H7, para extraplorar el poder bioprotector de Ent. mundtii CRL35 hacia otras cepas toxigénicas del patotipo estudiado. 


\section{MATERIALES Y MÉTODOS}

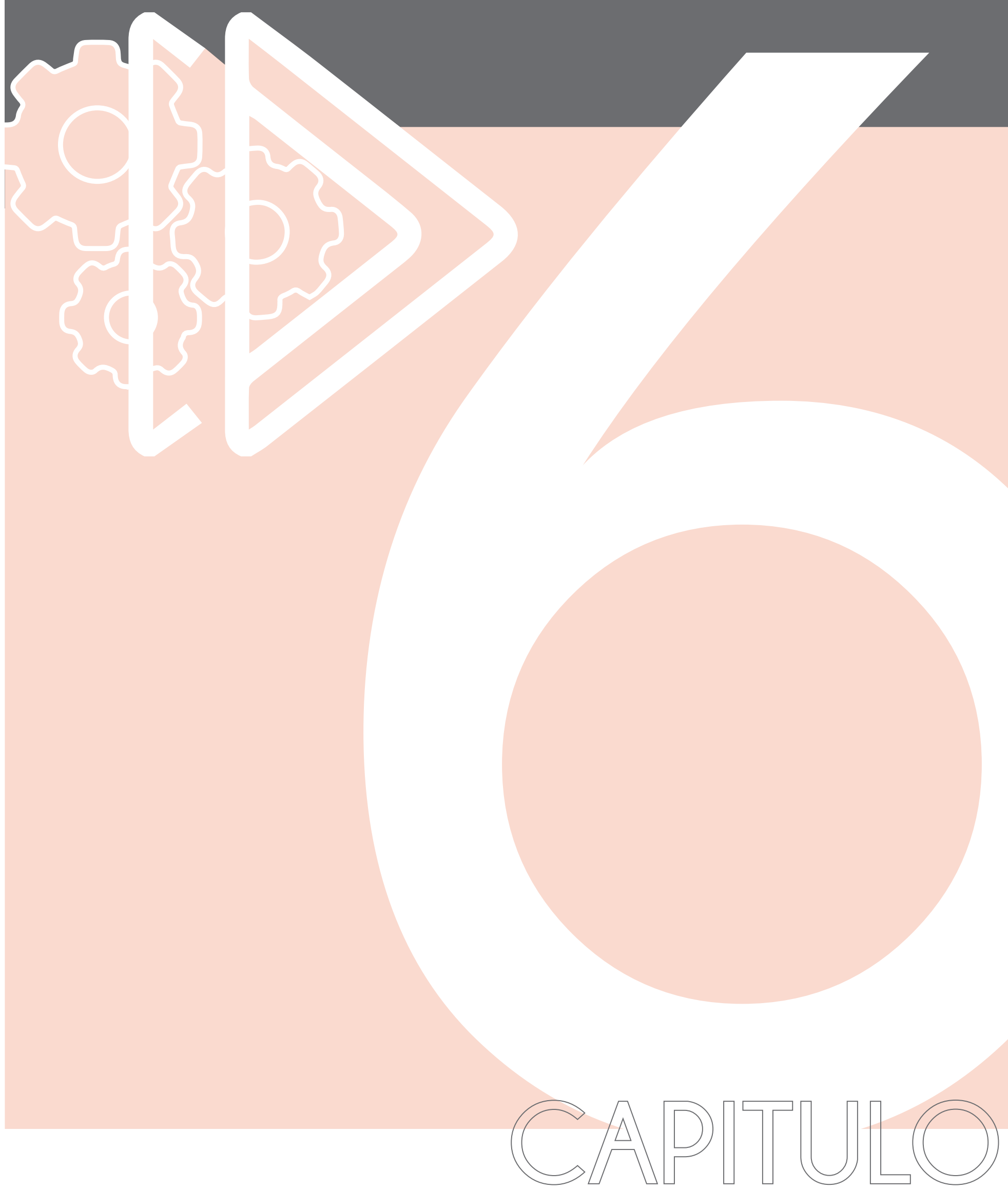




\section{CAPITULO 6 MATERIALES Y MÉTODOS}

\section{GENERALES}

Las cepas utilizadas en este trabajo se describen en la siguiente tabla:

Tabla 6.1. Cepas utilizadas en este trabajo. Se describe su origen y utilidad.

\begin{tabular}{|c|c|c|c|}
\hline Cepa & Origen & $\begin{array}{c}\text { Principales características - } \\
\text { Utilidad }\end{array}$ & Referencia \\
\hline $\begin{array}{l}\text { Lactobacillus } \\
\text { curvatus } \\
\text { CRL705 }\end{array}$ & $\begin{array}{l}\text { Embutidos } \\
\text { artesanales } \\
\text { argentinos }\end{array}$ & $\begin{array}{c}\text { Productora de dos tipos de } \\
\text { bacteriocinas, AL } 705 \text { (antilisteria) } \\
\text { y Lactocina } 705 \text { (activa contra } \\
\text { Brochotrix thermosfacta, y otras } \\
\text { BL) Capacidad proteolítica, } \\
\text { peptidogénica. }\end{array}$ & Vignolo y col. (1988) \\
\hline $\begin{array}{l}\text { Enterococcus } \\
\text { mundtii CRL35 }\end{array}$ & $\begin{array}{l}\text { Queso artesanal } \\
\text { (Tafí del Valle) }\end{array}$ & $\begin{array}{c}\text { Productora de bacteriocina, } \\
\text { enterocina CRL35, con actividad } \\
\text { antagónica frente a Listeria } \\
\text { monocytogenes y con } \\
\text { propiedades antivirales }\end{array}$ & Farias y col. (1996) \\
\hline $\begin{array}{l}\text { Lactobacillus } \\
\text { plantarum } \\
\text { CRL681 }\end{array}$ & $\begin{array}{l}\text { Embutidos } \\
\text { artesanales } \\
\text { argentinos }\end{array}$ & $\begin{array}{c}\text { Buen potencial acidogénico, } \\
\text { actividad proteolítica y } \\
\text { peptidogénica, capacidad para } \\
\text { degradar aminas biógenas in } \\
\text { vitro. }\end{array}$ & $\begin{array}{l}\text { Vignolo y col. (1988) } \\
\text { Fadda y col. (1999) } \\
\text { Fadda y col. (20 10) }\end{array}$ \\
\hline $\begin{array}{c}\text { Escherichia coli } \\
\text { O 157:H7 } \\
\text { NCTC } 12900\end{array}$ & $\begin{array}{l}\text { Aislado de muestra } \\
\text { clínica en Austria } \\
\text { (1992) }\end{array}$ & $\begin{array}{c}\text { Cepa patógena modelo en este } \\
\text { trabajo }\end{array}$ & Best y col. (2003) \\
\hline $\begin{array}{l}\text { Escherichia coli } \\
\text { C600:: } \Delta \text { tox }\end{array}$ & $\begin{array}{l}\text { Cepa construida a } \\
\text { partir de la cepa } \\
\text { salvaje C600 }\end{array}$ & $\begin{array}{l}\text { Derivada de C600 con el gen gfp } \\
\text { reemplazando al gen stx }\end{array}$ & $\begin{array}{l}\text { Gamage y col. } \\
(2003)\end{array}$ \\
\hline $\begin{array}{c}\text { Escherichia coli } \\
\text { O157:H7 } \\
\text { EDL933 }\end{array}$ & $\begin{array}{c}\text { Carne de } \\
\text { hamburguesa } \\
\text { cruda implicada } \\
\text { en un brote de } \\
\text { colitis hemorrágica }\end{array}$ & $\begin{array}{l}\text { Aislado clínico virulento utilizado } \\
\text { como control positivo en la } \\
\text { detección de genes de virulencia }\end{array}$ & ATCC ${ }^{\circledR} 43895$ \\
\hline $\begin{array}{l}\text { Listeria } \\
\text { monocytogenes } \\
\text { FBUNT }\end{array}$ & $\begin{array}{c}\text { Líquido } \\
\text { cefalorraquídeo } \\
\text { de recién nacido } \\
\text { (San Luis, } \\
\text { Argentina 1996) }\end{array}$ & $\begin{array}{c}\text { Utilizada como cepa sensible } \\
\text { para evaluar actividad antilisteria } \\
\text { de enterocina } 35\end{array}$ & Laciar y col. (201 l) \\
\hline $\begin{array}{l}\text { Escherichia coli } \\
\text { B }\end{array}$ & $\begin{array}{c}\text { Descendiente } \\
\text { clonal de Bacillus } \\
\text { coli }\end{array}$ & $\begin{array}{c}\text { Cepa sensible al fago W933 } \\
\text { utilizada para la titulación del } \\
\text { mismo. }\end{array}$ & $\begin{array}{l}\text { Daegelen y col. } \\
\text { (2009) }\end{array}$ \\
\hline
\end{tabular}




\section{Conservación de cepas}

Para la conservación de las cepas de BL utilizadas, las mismas fueron transferidas dos veces en MRS (Merck, Buenos Aires, Argentina) (De Man y col., 1960) e incubadas a $30^{\circ} \mathrm{C}$ durante $16 \mathrm{~h}$ (fase estacionaria). Las células fueron centrifugadas ( $10.000 \mathrm{xg}, 5 \mathrm{~min}$ ) y resuspendidas en medio de cultivo protector Leche Extracto de Levadura (LEL)-Clicerol estéril; el cultivo se concentró 10 veces y se fraccionó en viales estériles almacenados a $-70^{\circ} \mathrm{C}$ hasta su uso.

Para la conservación de las distintas cepas de E. coli utilizadas en este trabajo, cultivos crecidos en caldo LB (Sambrook y col., 1989) hasta fase estacionaria, fueron centrifugados (2300 xg, $5 \mathrm{~min}$ ) y resuspendidos en LB con glicerol (20\% v/v) y almacenados a $-70^{\circ} \mathrm{C}$ hasta su uso.

Para la conservación de Listeria monocytogenes FBUNT, la cepa desarrollada en caldo TSB hasta fase estacionaria, se centrifugó (2300 xg, $5 \mathrm{~min}$ ), y resuspendió en TSB blando (agar $0,7 \%$ ) y se almacenó a $-70^{\circ} \mathrm{C}$ hasta su uso.

\section{Propagación}

Para obtener cultivos activos de las cepas lácticas utilizadas se realizaron dos pasajes sucesivos de las mismas en caldo MRS incubados a $30^{\circ} \mathrm{C}$ durante 16 18 h (inóculo al 6\%).

En el caso de las cepas de E. coli, fueron transferidas dos veces en caldo LB y se incubó a $37^{\circ} \mathrm{C}$ en agitación (220 xg) durante 8 h, en la primera transferencia, y durante $16 \mathrm{~h}$ en la segunda.

Listeria monocytogenes FBUNT fue transferida a caldo TSB realizando dos pasajes sucesivos en dicho medio e incubando a $37^{\circ} \mathrm{C}$ durante $16 \mathrm{~h}$, para obtener de esa forma un cultivo activo.

\section{Medios de cultivo}

MRS

El medio Man Rogosa y Sharpe (De Man y col., 1960) se compone de peptona de carne $10 \mathrm{~g} / /$; extracto de carne $10 \mathrm{~g} /$, extracto de levadura $5 \mathrm{~g} / \mathrm{l}$, glucosa 20 g/l, K2HPO4 2 g/l, acetato de sodio 5 g/l, citrato triamónico 2 g/l, MgSO4.7H2O 0,2 g/l, MnSO4.H2O 0,05 g/l y Tween 80 l g/l. Se esterilizó en autoclave a 1 atm de 
presión y $121{ }^{\circ} \mathrm{C}$ durante 20 min. Para obtener MRS agarizado, se agregó agar 1,5\% al caldo y se esterilizó en las mismas condiciones.

$\underline{L B}$

El medio Luria Bertani (Sambrook y col., 1989) se compone de tripteína $10 \mathrm{~g} / \mathrm{l}$, cloruro de sodio $10 \mathrm{~g} / \mathrm{l}$ y extracto de levadura $5 \mathrm{~g} / \mathrm{l}$. Se esterilizó en autoclave a 1 atm de presión y $121^{\circ} \mathrm{C}$ durante 20 min. Para obtener LB agar blando se agregó agar $0,7 \%$ al caldo y se esterilizó en las mismas condiciones.

\section{Mac Conkey Agar}

El medio Mac Conkey agar (MacFaddin, 1985) se compone de peptona de carne 1,5 g/l, peptona de gelatina $17 \mathrm{~g} / \mathrm{l}$, tripteína $1,5 \mathrm{~g} / \mathrm{l}$, lactosa $10 \mathrm{~g} / \mathrm{l}$, sales biliares 1,5 g/l, cloruro de sodio $5 \mathrm{~g} / \mathrm{l}$, rojo neutro 0,03 g/l, cristal violeta 0,001 g/l, agar 13,5 g/l. Se esterilizó en autoclave a 1 atm de presión y $121^{\circ} \mathrm{C}$ durante $20 \mathrm{~min}$. En este medio desarrollan bacilos Gram negativos aerobios y anaerobios facultativos y todas las especies de la familia Enterobacteriaceae desarrollan en el mismo.

\section{Mac Conkey Sorbitol Agar}

El medio Mac Conkey sorbitol (Ratman y March, 1986) se compone de peptona $20 \mathrm{~g} / \mathrm{l}$, sorbitol $10 \mathrm{~g} / \mathrm{l}$, sales biliares 1,5 g/l, cloruro de sodio $5 \mathrm{~g} / \mathrm{l}$, rojo neutro 0,03 g/l, cristal violeta 0,001 g/l, agar $15 \mathrm{~g} / \mathrm{l}$. Se esterilizó en autoclave a 1 atm de presión y $121{ }^{\circ} \mathrm{C}$ durante $20 \mathrm{~min}$. Constituye un medio selectivo y diferencial para el crecimiento de E. coli O 157:H7. Esta cepa de E. coli fermenta lactosa como todas las cepas del género, pero a diferencia de éstas, no es capaz de fermentar sorbitol. Por lo tanto los medios que contienen lactosa no permiten la diferenciación entre ellas. Este medio de cultivo reemplaza la lactosa por sorbitol, por lo cual los microorganismos fermentadores de sorbitol se desarrollan dando colonias de color rojizo-rosadas por descenso del pH y viraje del indicador, mientras que los microorganismos no fermentadores de éste azúcar (E. coli O 157:H7) se desarrollan dando colonias incoloras.

\section{LEL-Clicerol}

El medio LEL se compone de leche descremada en polvo 10,0 g, extracto de levadura 0,5 g, glucosa 1,0 g y agua destilada en c.s.p. $1000 \mathrm{ml}$.

Este medio se esterilizó a $115^{\circ} \mathrm{C}(0,6-0,7$ atm de presión) durante 20 min. Luego, se agregó glicerol, esterilizado previamente $\left(121^{\circ} \mathrm{C}, 20 \mathrm{~min}\right)$, con una concentración final del 15\% (v/v). 
$\underline{\mathrm{TSB}}$

El medio caldo tripteína de soja del inglés Triptein Soy Broth (TSB) se compone de tripteína $17 \mathrm{~g}$, peptona de soya $3 \mathrm{~g}$, cloruro de sodio $5 \mathrm{~g}$, fosfato dipotásico $2,5 \mathrm{~g}$ y glucosa $2,5 \mathrm{~g}$ y agua destilada en c.s.p. $1000 \mathrm{ml}$. Se esterilizó en autoclave a 1 atm de presión y $121{ }^{\circ} \mathrm{C}$ durante $20 \mathrm{~min}$. Es un medio nutritivo que favorece el crecimiento de una amplia variedad de microorganismos, en especial las bacterias anaerobias facultativas y aerobias comunes.

$\underline{P C A}$

El medio PCA, del inglés Plate Count Agar se compone de tripteína $5 \mathrm{~g}$, extracto de levadura $2,5 \mathrm{~g}$, glucosa $1 \mathrm{~g}$, agar $14 \mathrm{~g}$ y agua destilada en c.s.p. 1000 $\mathrm{ml}$. Se esterilizó en autoclave a $\mathrm{a} \mathrm{atm}$ de presión y $121^{\circ} \mathrm{C}$ durante $20 \mathrm{~min}$. Es un medio nutritivo poco selectivo usado para el crecimiento de mesofilos aerobios totales.

\section{Sistema Cárnico Modelo (SCM)}

El SCM utilizado como medio de cultivo se preparó de acuerdo a Fadda y col. (1998) con algunas modificaciones. Brevemente, se homogeneizaron $10 \mathrm{~g}$ de músculo semimembranosus bovino con $100 \mathrm{ml}$ de agua desionizada durante 8 minutos en un mezclador Stomacher 400 (Stomacher, Londres, Reino Unido). El homogeneizado se centrifugó (1 $4.000 \mathrm{xg}, 20 \mathrm{~min}$ a $4^{\circ} \mathrm{C}$ ). El sobrenadante que contenía proteínas sarcoplásmicas entre otros compuestos solubles, se filtró a través de papel Whatman, se esterilizó por filtración a través de un filtro de 0,22 $\mu \mathrm{m}$ (diámetro del poro) (Steritop GP, Biopore, Buenos Aires, Argentina) y se suplementó con glucosa 0,5\% ( $p / v)$ y 0,01\% (v/v) de Tween 80. La esterilidad del sistema se confirmó por plaqueo en PCA. 


\section{CARACTERIZACIÓN MOLECULAR DE E. coli O 157:H7 NCTC12900 Y EVALUACIÓN DEL POTENCIAL INHIBIDOR DE CEPAS LÁCTICAS PRESELECCIONADAS}

\section{Caracterización de factores de virulencia de la cepa modelo E. coli O 157:H7 NCTC12900 mediante PCR}

\section{Extracción de ADN cromosómico de E. coli}

La extracción de ADN cromosómico se llevó a cabo según Ausubel (1999). Se utilizaron células provenientes de $5 \mathrm{ml}$ de un cultivo en fase logarítmica. Las células se cosecharon por centrifugación $(8.000 \times \mathrm{g}, 10 \mathrm{~min}$ ), se resuspendieron en $500 \mu \mathrm{l}$ de buffer TE (Tris-HCl 10 mM, EDTA-Na2 1 mM, pH 8) Luego se agregaron $50 \mu l$ de dodecilsulfato de sodio (SDS) al $10 \%(\mathrm{p} / \mathrm{v}), 3 \mu$ l de proteinasa $\mathrm{K}(20 \mu \mathrm{g} / \mathrm{ml})$ y se incubó durante I h a $37^{\circ} \mathrm{C}$, mezclando periódicamente por inversión. A continuación, se agregaron $100 \mu$ de $\mathrm{NaCl} 5 \mathrm{M}$ y I vol de la solución cloroformo: alcohol isoamílico (24:1) preparada en el momento y se incubó 30 min a temperatura ambiente, mezclando periódicamente por inversión. Luego se centrifugó ( $10.000 \times g, 10 \mathrm{~min})$ y se recuperó el ADN de la fase acuosa mediante precipitación con 0,6 vol de isopropanol. Se centrifugó ( $10.000 \times 9,10 \mathrm{~min}$ ) y el precipitado (ADN) se lavó con $300 \mu$ letanol 70\% ( $/ / \mathrm{v})$ centrifugando inmediatamente ( $10.000 \times \mathrm{g}, 3 \mathrm{~min})$. El ADN obtenido se dejó secar en baño seco (termobloque) a $37^{\circ} \mathrm{C}$ durante 20 min. El ADN fue resuspendido en $50 \mu$ de agua Milli-Q esterilizada.

\section{$\underline{P C R}$}

Las reacciones de PCR, se realizaron en un termociclador MyCycler ${ }^{T M} T$ Thermal Cycler System with Gradient Option (Bio-Rad Laboratories Inc.). Cada reacción contenía: $5 \mu$ de buffer 5X; 2,5 $\mu$ l de cada cebador $10 \mu \mathrm{M} ; \quad I \mu l$ de desoxiribonucleósidostrifosfato (dNTPs) 5 mM; 0,1 $\mu$ de ADN polimerasa CoTaq ${ }^{\circledR}$ (Promega Co.); 50 ng de ADN molde y 11,9 $\mu$ de agua Milli-Q, en un volumen final de $25 \mu$ l. Las condiciones utilizadas fueron las siguientes: 3 min a $95^{\circ} \mathrm{C} ; 30$ ciclos de: 30 s a $95^{\circ} \mathrm{C}, 30$ s a $50^{\circ} \mathrm{C}$ y 30 s a $72^{\circ} \mathrm{C}$; seguido de una extensión final de 5 min a $72^{\circ} \mathrm{C}$.

A continuación, en la Tabla 6.2, se detallan los cebadores utilizados. 
Tabla 6.2. Se detalla la secuencia de los cebadores utilizados en las reacciones de PCR.

\begin{tabular}{|c|c|c|c|c|}
\hline Gen & Proteína & $\begin{array}{c}\text { Secuencia de cebadores } \\
\text { utilizados } \\
5^{\prime}-\rightarrow 3^{\prime}\end{array}$ & $\begin{array}{c}\text { Tamaño } \\
\text { del } \\
\text { producto } \\
\text { amplificado } \\
\text { (pb) }\end{array}$ & $\begin{array}{l}\text { Referen } \\
\text { cias }\end{array}$ \\
\hline $\operatorname{gad} A$ & $\begin{array}{c}\text { Clutamato } \\
\text { descarboxilasa } \\
\text { alfa }\end{array}$ & $\begin{array}{c}\text { F- CATCAAATCCCGTTCCCAAG } \\
\text { R-CGCCGAACTCCCACACGATATCC }\end{array}$ & 373 & $\begin{array}{l}\text { Nadya y } \\
\text { col. } \\
\text { (2016) }\end{array}$ \\
\hline stx 1 & Verotoxina & $\begin{array}{l}\text { F- ATAAATCCCCATTCGTTCACTAC } \\
\text { R - ACAACGCCCACTCACATCATC }\end{array}$ & 180 & \multirow{3}{*}{$\begin{array}{l}\text { Paton y } \\
\text { Paton } \\
\text { (1998) }\end{array}$} \\
\hline eaeA & Intimina & $\begin{array}{l}\text { F- CACCCGCCACAACCATAACC } \\
\text { R - CCACCTCCACCAACAACACC }\end{array}$ & 384 & \\
\hline hlyA & Hemolisina & $\begin{array}{l}\text { F- CCATCATCAACCCTACGTTCC } \\
\text { R - AATCACCCAACCTCGTTAACCT }\end{array}$ & 534 & \\
\hline
\end{tabular}

\section{Electroforesis de ADN en geles de agarosa}

La electroforesis en geles de agarosa se utilizó para visualizar el ADN cromosómico y aquellos fragmentos amplificados por PCR. La velocidad de migración de las moléculas de ADN en un gel de agarosa está determinada por el tamaño molecular, la concentración de agarosa, la conformación de la molécula y el voltaje usado, entre otros factores. Se utilizaron geles horizontales de agarosa aplicando un potencial eléctrico de $80 \mathrm{~V}$ durante 60 min y un marcador de peso molecular de 100 pb (Invitrogen TM, Life Technologies Co.) para geles al 1,5\% (p/v) de agarosa. Para la tinción del ADN se utilizó el colorante fluorescente GelRedTM (Biotium Inc.; Hayward, CA, Estados Unidos) (dilución 1/10.000).

\section{Purificación y secuenciación de los fragmentos amplificados}

Los fragmentos de ADN obtenidos en las reacciones de PCR se purificaron usando el kit AccuPrep, Gel Purification Kit, Bioneer (Cenbiotech, Buenos Aires, Argentina), y fueron secuenciados en el Servicio de Secuenciación de CCTCONICET-Tucumán. Las secuencias nucleotídicas obtenidas se analizaron usando BLASTn (The Basic Local Alignment Search Tool) del NCBI (http://www.ncbi.nlm.nih.gov/BLAST). Se tomaron como parámetros de análisis un porcentaje de identidad $\geq 50 \%$ y un e-value $\leq 1 e-10$. 


\section{Selección de cepa BL con capacidad inhibitoria sobre ECEH}

\section{Ensayos de inhibición en placa}

El ensayo se llevó a cabo según Salvucci y col. (2007) con algunas modificaciones. A fin de dilucidar los potenciales mecanismos de inhibición hacia ECEH involucrados, se evaluaron las siguientes condiciones para cada cepa: (1) células intactas/viables, los cultivos celulares se lavaron con solución fisiológica eliminando los efectos de los factores solubles del sobrenadante; (2) células no viables, los cultivos celulares se lavaron con agua destilada y se calentaron durante 15 minutos a $95^{\circ} \mathrm{C}$; (3) células tratadas, los cultivos celulares se lavaron con solución fisiológica y se resuspendieron en $1 \mathrm{mg} / \mathrm{ml}$ de solución de lisozima para ser incubados durante 2 horas, a fin de evaluar si la estructura de la pared celular estaba implicada en la inhibición del patógeno; (4) cultivo activo directo, para evaluar la totalidad de componentes (células viables más productos metabólicos) presentes en el medio; (5) sobrenadante libre de células calentado $\left(5 \mathrm{~min}, 95^{\circ} \mathrm{C}\right.$ ), para evaluar la inhibición bacteriana debido a ácido, bacteriocinas y otros compuestos solubles termoestables; (6) sobrenadante exento de células calentado $\left(5 \mathrm{~min}, 95^{\circ} \mathrm{C}\right.$ ) y neutralizado a pH $7 \mathrm{con} \mathrm{NaOH} 1 \mathrm{~N}$, para neutralizar los ácidos producidos; (7) sobrenadante libre de células sin tratar, para evaluar factores solubles adicionales que podrían inhibir el patógeno; (8) solución de ácido Iáctico al $4 \%$ como control del efecto ácido. Se colocaron gotas de $5 \mu$ de cada condición de cultivo de BL sobre una placa conteniendo MRS agar. El césped indicador se preparó añadiendo $100 \mu \mathrm{l}$ de un cultivo activo de ECEH a $10 \mathrm{ml}$ de LB agar blando $(0,7 \%$, el cual fue vertido sobre el MRS agar inoculado con los distintos tratamientos del cultivo láctico en estudio. Las placas se incubaron a $30^{\circ} \mathrm{C}$ durante 24 h. La presencia de halos de inhibición alrededor de los spots inoculados en el agar MRS se consideró inhibición positiva de E. coli NCTC12900.

\section{Cocultivos en sistema cárnico modelo}

Los cultivos de cada cepa de BL con ECEH se llevaron a cabo en SCM para evaluar el desempeño de ambos microorganismos tanto en cocultivo como en forma individual. Cincuenta $\mathrm{ml}$ del SCM se inocularon con aproximadamente $10^{6} \mathrm{UFC} / \mathrm{ml}$ de $\mathrm{BL}$ y $10^{4} \mathrm{UFC} / \mathrm{ml}$ de ECEH y se incubaron en condiciones estáticas a $30^{\circ} \mathrm{C}$ durante 96 h. Además, cada microorganismo se cultivó individualmente en las mismas 
condiciones $\left(30^{\circ} \mathrm{C}, 96 \mathrm{~h}\right.$, mismo inóculo) para evaluar el comportamiento de cada cepa sin competencia. Se tomaron muestras a las 0, 3, 6, 8, 24, 48, 72 y 96 h de incubación a partir de las cuales se realizó determinación de pH y análisis de la viabilidad de ambos grupos microbianos utilizando medios agarizados selectivos. Para el recuento bacteriano, se prepararon diluciones decimales y se plaquearon en el medio correspondiente, agar MRS para BL y agar Mac Conkey (Britania, Buenos Aires, Argentina) para ECEH, y se incubaron a $30^{\circ} \mathrm{C}$ durante 48 y $24 \mathrm{~h}$, respectivamente. Las mediciones de $\mathrm{pH}$ se determinaron usando pHmeter Altronix TPX I (Nueva York, EE. UU.). Se llevaron a cabo tres réplicas biológicas independientes para cada cultivo (mixto $e$ individuales). 


\section{ESTUDIO DE LA INTERACCIÓN BL-ECEH in vitro}

Estos estudios se realizaron con la con la cepa seleccionada, Ent. mundtii CRL35.

Los ensayos de titulación de bacteriocina y ensayos proteómicos se focalizaron en dos momentos puntuales de la interacción Ent. mundtii - ECEH en SCM: T1, correspondiente a la fase de crecimiento exponencial de ambos microorganismos, lo cual se evidencia luego de 6 h de incubación tanto en cultivos individuales como en cocultivos, y T2 correspondiente a la fase de crecimiento estacionaria de Ent. mundtii y fase de muerte de ECEH, lo cual se produce luego de 30 h de incubación en cocultivo, mientras que en cultivos individuales, dichas fases del crecimiento se presentan a las $30 \mathrm{~h}$ para Ent. mundtii y $96 \mathrm{~h}$ para ECEH (Tabla 6.3).

Tabla 6.3.Tiempo de colecta en horas (Ent. mundtii/ECEH) correspondientes a T1 y T2 en cultivo individual y en cocultivo.

T1

\begin{tabular}{ccc}
\hline $\begin{array}{c}\text { Cultivo } \\
\text { Individual }\end{array}$ & $6 / 6$ & $\begin{array}{c}30 \text { (fase estacionaria) } \\
\text { (fase exponencial) }\end{array}$ \\
\hline Cocultivo & $6 / 6$ & 30 (fase estacionaria) \\
& (fase exponencial) & 130 (fase de muerte) \\
\hline
\end{tabular}

\section{Estudio protéómico}

Se abordó un análisis proteómico mediante electroforesis bidimensional (E2D) a fin de evaluar la interacción Ent. mundtii - ECEH en SCM. El sistema fue estudiado a TI y T2, en cocultivo y cultivos individuales como fue detallado anteriormente.

\section{Recuperación de células para análisis proteómicos}

Ent. mundtii se incubó individualmente y en cocultivo con ECEH, en $100 \mathrm{ml}$ del SCM para lograr una cantidad suficiente de células para el análisis proteómico. Como se explicó anteriormente se estudiaron las condiciones T1 y T2. Las células de diferentes cultivos se recogieron por centrifugación a $8.000 \mathrm{xg}$ durante $10 \mathrm{~min}$ a 
$20^{\circ} \mathrm{C}$ y se lavaron dos veces con $40 \mathrm{ml}$ de tampón Tris-HCl 0,1 M, pH 7,5. Los pellets resultantes se almacenaron a $-20^{\circ} \mathrm{C}$ hasta su lisis para la extracción de proteínas. Se realizaron tres réplicas biológicas independientes para cada condición.

\section{Preparación de extractos de proteínas libres de células para análisis proteómicos}

Los precipitados celulares obtenidos de ECEH y Ent. mundtii correspondientes a sus cultivos individuales a TI fueron mezclados antes de la lisis realizándose el mismo procedimiento para T2 (Figura 6.1). Este procedimiento se llevó a cabo para estandarizar la técnica y evitar las diferencias en la eficacia de ruptura celular entre mono y cocultivos y por ende diferencias en el enriquecimiento proteico de cada microorganismo en geles 2D, lo cual afectaría las comparaciones proteómicas. Las proporciones celulares de cada cultivo individual utilizado para dichas mezclas se establecieron de acuerdo con los recuentos celulares obtenidos en el cocultivo respectivo (TI ○ T2) de manera que en la mezcla exista una relación similar entre los dos microorganismos. De esta forma, se asegura que se coloquen $600 \mathrm{\mu g}$ de proteínas en la tira de IPC (del inglés immobilized pH gradient), con la misma proporción de proteína de cada microorganismo que en las tiras de IPC con muestras del cocultivo. Cada una de estas mezclas sintéticas (MS) constituirá los controles respectivos en T1 y T2 (ver la Figura 6.1 para más detalles). Los precipitados celulares provenientes de estas MS así como los provenientes de los cocultivos, tanto para Tl como para T2, fueron sometidos al siguiente proceso de ruptura celular

Ruptura celular: Los pellets celulares obtenidos se mezclaron con perlas de vidrio ( $150 \pm 212 \mu \mathrm{m}$ de diámetro, Sigma-Aldrich Co., St. Lovis, MO, EE. UU.) y se resuspendieron en tampón Tris- $\mathrm{HCl}$ 0,1 M, pH 7,5 en una relación 1: 2: 1 (pellet: tampón: perla). Luego, las células se rompieron usando un disruptor celular MiniBeadBeater-8 (BiospecProducts Inc., Bartlesville, OK, EE. UU.) durante 10 min ( 10 ciclos de 1 min cada uno, con intervalos de 1 minuto en hielo entre ciclos). Para eliminar restos celulares, células intactas y perlas de vidrio, las muestras se centrifugaron a $14.500 \mathrm{xg}, 5 \mathrm{~min}, 15^{\circ} \mathrm{C}$. El sobrenadante obtenido constituye el extracto libre de células. La concentración de proteínas totales de los extractos se determinó utilizando un reactivo de Bradford concentrado comercial (Bio-Rad Laboratories Inc.) siguiendo las instrucciones del fabricante y utilizando albúmina sérica bovina como estándar (0,05-0,50 mg/ml). Se agregó $10 \mu \mathrm{l}$ de muestra a $200 \mu \mathrm{l}$ de la solución de Bradford. La mezcla se incubó a temperatura ambiente durante 10 min y se 
determinó la concentración de proteínas espectrofotométricamente usando un lector de microplacas VERSAmax ${ }^{T M}$ (Sunnyvale, CA, EE.UU.) midiendo la absorbancia a 595 $\mathrm{nm}$. Los resultados se expresaron en mg/ml. Finalmente, se almacenaron alícuotas de $600 \mu \mathrm{g}$ de proteína a $-70^{\circ} \mathrm{C}$, hasta su posterior análisis de E2D. 


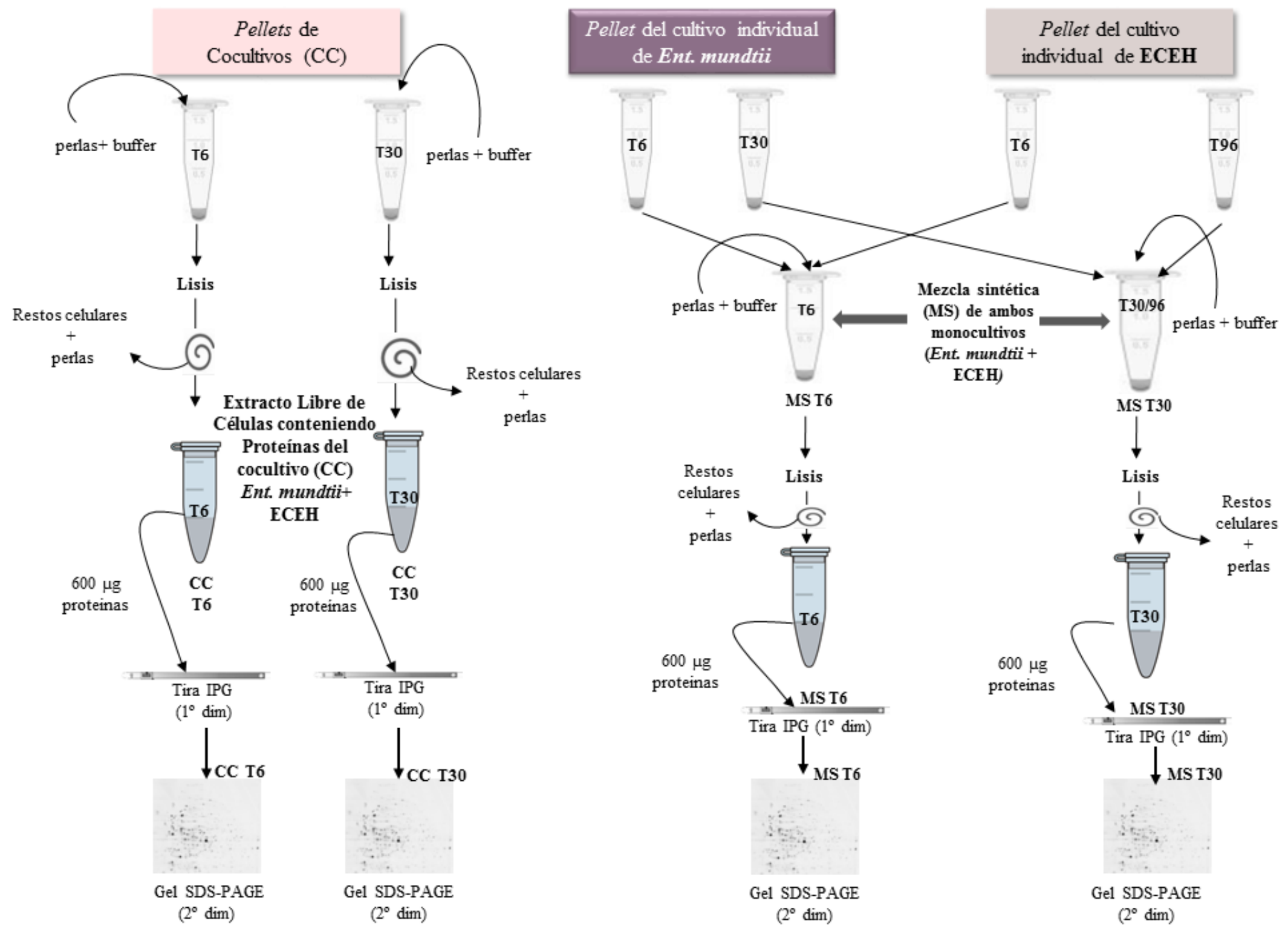

Figura 6.1. Descripción esquemática de la preparación de extractos libres de células para el análisis proteómico. 
Isoelectroenfocado

Las muestras fueron tratadas con las soluciones de desnaturalización (Tabla 6.4) y solubilización (Tabla 6.5) y luego se realizó la rehidratación pasiva (sin corriente eléctrica) de las tiras en el equipo IPGphor durante 20-24 h empleando el tampón de rehidratación que se detalla en la Tabla 6.6. Todas las soluciones se prepararon en el momento de utilizar.

Tabla 6.4. Componentes para realizar $10 \mathrm{ml}$ de solución de desnaturalización.

\begin{tabular}{cc}
\hline \multicolumn{2}{c}{ Solución de desnaturalización } \\
\hline Urea $(6,5 \mathrm{M})$ & $3,94 \mathrm{~g}$ \\
\hline Tiourea $(0,17 \mathrm{M})$ & $1,65 \mathrm{~g}$ \\
\hline Agua $(\mathrm{MQ})$ csp & $10 \mathrm{ml}$ \\
\hline \hline
\end{tabular}

Luego de la solubilización de la urea/tiourea, se agregó 0,1 g de amberlita para desionizar en agitación suave $1 \mathrm{~h}$.

Tabla 6.5. Componentes de la solución de solubilización.

\begin{tabular}{|c|c|}
\hline \multicolumn{2}{|c|}{ Solución de solubilización (S) - 12 muestras } \\
\hline CHAPS ( $4 \%$ final) & $20 \mathrm{mg}$ \\
\hline DTT $(100 \mathrm{mM})$ & $8 \mathrm{mg}$ \\
\hline Tampón Tris-HCl 2 M pH 8.8 & $10 \mu \mathrm{L}$ \\
\hline Solución de desnaturalización & $0,5 \mathrm{ml}$ \\
\hline \multicolumn{2}{|c|}{ Tabla 6.6. Componentes de la solución de rehidratación. } \\
\hline \multicolumn{2}{|c|}{ Solución de rehidratación (R) - 12 muestras } \\
\hline CHAPS ( $4 \%$ final) & $240 \mathrm{mg}$ \\
\hline DTT (100mM) & $96 \mathrm{mg}$ \\
\hline IPG (pH 4-7) & $120 \mu \mathrm{L}$ \\
\hline Azul de bromofenol $(0,002 \%)$ & punta de espátula \\
\hline Solución de desnaturalización & $6 \mathrm{ml}$ \\
\hline
\end{tabular}

Preparación de la muestra (Grosu-Tudor y col., 2016)

Para preparar la muestra se añadió 1 ll de benzonasa para la digestión del $\mathrm{ADN}$ y $1 \mu \mathrm{l}$ de $\mathrm{MgSO}_{4} 1 \mathrm{M}$ (o $\mathrm{MgCl}_{2} \mid \mathrm{M}$ ). Se incubó $30 \mathrm{~min}$ a $37^{\circ} \mathrm{C}$. Para la precipitación de proteínas, se agregó 2 volúmenes de acetona por volúmenes de muestra. Se homogeneizó muy bien en vortex y se dejó reposar a $-20^{\circ} \mathrm{C}$ durante toda 
la noche. Luego, se recuperó el pellet por centrifugación (15.600 ×9, 15 min) y se eliminó la acetona. Se secó en baño seco a $95^{\circ} \mathrm{C}$ ( 1 -3 min).

\section{Siembra en las tiras de isoelectroenfocado (IEF) para la rehidratación}

Se solubilizaron las proteínas concentradas y secas, obtenidas en el punto anterior en $40 \mu$ de la solución de solubilización (S), se diluyó con $300 \mu l$ de la solución de rehidratación ( $R$ ) (para las tiras de $17 \mathrm{~cm}$ utilizadas). Se centrifugó a $1.100 \times g$ por 10 min. Luego, se niveló el dispositivo de hidratación (Resweling tray). A continuación se depositaron las muestras en los canales, se quitó el film protector de las tiras y con pinzas se colocaron con el gel hacia abajo sobre las muestras. Se eliminaron las burbujas y se cubrieron las tiras con $3-4 \mathrm{ml}$ de aceite mineral para evitar deshidratación. Luego, se dejaron tapadas con papel de aluminio a temperatura ambiente durante 18-20 h para su hidratación e incorporación de la muestra a la tira de IPC (Figura 6.2).

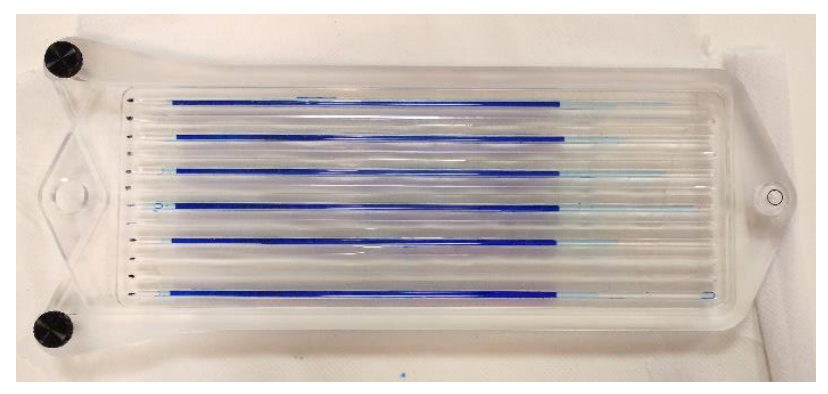

Figura 6.2. Tiras de isoelectroenfoque con la solución de hidratación. Las muestras se incorporaron a las tiras de isoelectroenfoque por hidratación pasiva.

Luego de la rehidratación se preparó el sistema para el IEF: se niveló correctamente el equipo Ettan IPGphor (nivel de burbuja), y se posicionó el Manifold sobre el equipo. Se agregaron $108 \mathrm{ml}$ de aceite mineral (Dry Strip Cover Fluid, CE, Pittsburgh, EEUU) para cubrir todas las calles del Manifold (Figura 6.3). A continuación se transfirieron las tiras, escurridas previamente en papel de filtro, al Manifold con el lado gel hacia arriba y extremo anódico (+) hacia el extremo en T. 


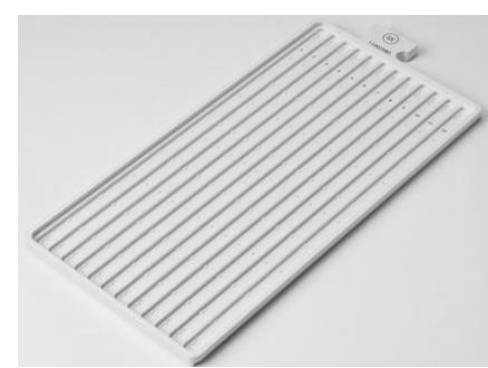

Figura 6.3. Manifold. En cada uno de los canales del manifold se colocaron las tiras del isoelectroenfocado con el gel hacia arriba.

\section{Primera dimensión IEF horizontal}

Se humedecieron las almohadillas de papel precortadas (2 por tira, una en cada extremo) con $150 \mu$ de agua bidestilada. Se colocaron en los extremos de las tiras para que queden solapados con el extremo del gel. Luego, se ubicaron los ensamblajes de los electrodos en posición open sobre las almohadillas y se controlaron que las puntas de los electrodos estén en contacto con la base de oro del equipo. Se cerró el equipo (Figura 6.4) y se corrió el programa de IEF. Este programa tiene los pasos que se detallan en la Tabla 6.7.

Tabla 6.7. Condiciones de electroforesis usadas.

\begin{tabular}{ccccc}
\hline & Modalidad & Voltaje $(\mathrm{Vh})$ & Tiempo $(\mathrm{h})$ & Voltaje total $(\mathrm{V})$ \\
\cline { 2 - 5 } 1 & Lineal & 500 & $1: 00$ & 500 \\
\hline 2 & Gradiente & 1000 & $8: 00$ & 6000 \\
\hline 3 & Gradiente & 8000 & $6: 00$ & 27000 \\
\hline 4 & Lineal & 10000 & $2: 00$ & 20000 \\
\hline & & & Total: 53500 \\
\hline
\end{tabular}

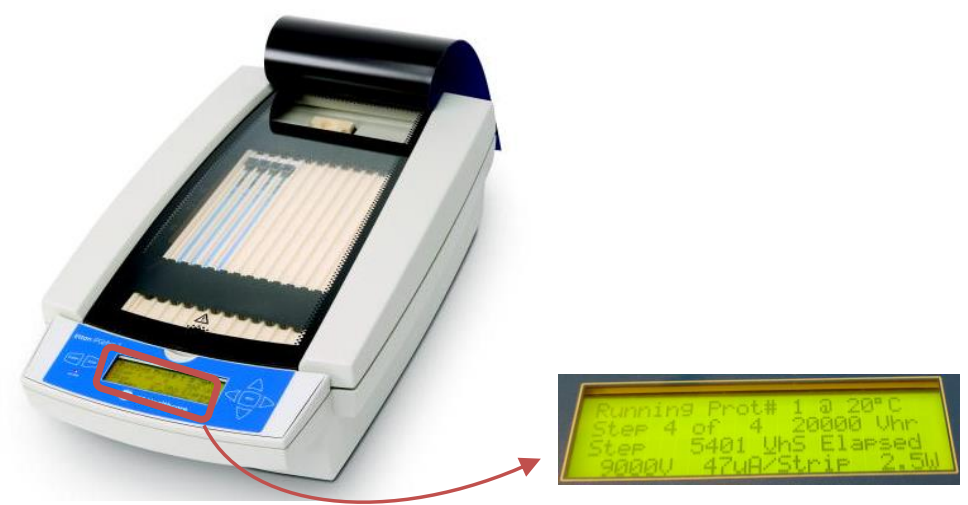

Figura 6.4. Equipo Ettan IPGphor para correr la primera dimensión. Se puede observar el detalle de la pantalla donde se van reportando todas las etapas de las condiciones utilizadas durante la corrida. 
Una vez finalizado el programa, se detuvo el equipo y se recuperaron las tiras escurriéndolas cuidadosamente en papel de filtro. Se las colocó en los tubos con tapa rosca cuidando que el gel no quede en contacto con el vidrio. Se conservaron las tiras a $-70^{\circ} \mathrm{C}$ hasta el momento de la segunda dimensión. Se lavó el equipo con detergente suave (Cleaning solution CE, Pittsburgh, EEUU), agua tibia $\left(40-50^{\circ} \mathrm{C}\right.$ ) y agua destilada.

\section{Segunda dimensión SDS-PACE con sistemas de electroforesis vertical}

Preparación del dispositivo para los geles

Se limpiaron los vidrios y las juntas con alcohol, se secó con papel tipo tissue compatible con proteómica. Se niveló y completó el dispositivo con los vidrios y entre los mismos se colocaron hojas plásticas de separación. Se cerró el sistema con tornillos y pinzas. Se niveló el sistema y posteriormente se llenó con solución acrilamida-bisacrilamida.

Los geles se prepararon con una solución de Acrilamida-Bis acrilamida (30\%T-0,5\% C) al 12,5\% como se detalla a continuación en la Tabla 6.8 .

Tabla 6.8. Componentes de la solución de separación para 6 geles.

\begin{tabular}{|c|c|}
\hline Componentes & $\begin{array}{c}\text { Gel Separación (6 geles) } \\
(12.5 \%)\end{array}$ \\
\hline Solución Acrilamida + bisacrilamida (S) & $172 \mathrm{ml}$ \\
\hline Tris $3 \mathrm{M} \mathrm{pH} 8.8$ & $106,53 \mathrm{ml}$ \\
\hline SDS 20\% (p/v) & $4,31 \mathrm{ml}$ \\
\hline $\mathrm{H}_{2} \mathrm{O}$ & $57,46 \mathrm{ml}$ \\
\hline Clicerol 50\% (v/v) & $86,21 \mathrm{ml}$ \\
\hline Persulfato 10\% (p/v) & $2,7 \mathrm{ml}$ \\
\hline TEMED & $0,354 \mathrm{ml}$ \\
\hline TOTAL (ml) & $429,56 \mathrm{ml}$ \\
\hline
\end{tabular}

EI TEMED y el persulfato se agregaron al último por ser los catalizadores. Se evitó la formación de burbujas tanto en la preparación de la solución como en el agregado de la solución para su solidificación en el dispositivo. Se agregó de manera constante y contínua la solución hasta $1 \mathrm{~cm}$ antes del extremo final del vidrio más corto.

Posteriormente se agregaron $2 \mathrm{ml}$ de isopropanol/ $\mathrm{H}_{2} \mathrm{O}(2 / 3)$ por cada gel a lo largo del mismo. Se dejó polimerizar durante 2 h (mínimo), para lvego eliminar el isopropanol y enjuagar y lavar con $\mathrm{H}_{2} \mathrm{O}$ destilada. 
Los geles solidificados se cubrieron en la parte superior con Tampón de migración IX, se colocaron en cámara fría hasta su uso, y se cubrieron con envoltura plástica.

Equilibrado de las tiras isoelectroenfocadas a sembrar

Previamente a la siembra en los geles de SDS PACE, las tiras se trataron con DTT (ditriotreitol) y con iodoacetamida a fin de reducir y alquilar, respectivamente, los puentes disulfuro presentes y de esa forma evitar la renaturalización de las proteínas. Se preparó la solución base como se detalla en la Tabla 6.9. Las tiras se enjuagaron dos veces con $5 \mathrm{ml}$ de la solución base.

Tabla 6.9. Solución base (preparar en el momento) (para 6 tiras).

\begin{tabular}{cc}
\hline \multicolumn{2}{c}{ Solución base } \\
\hline Componentes & Cantidad para 6 tiras \\
\hline Tris 1M pH 6,8 & $15 \mathrm{ml}$ \\
\hline Urea & $108 \mathrm{~g}$ \\
\hline SDS & $3 \mathrm{~g}$ \\
\hline H2O miliQ & $105 \mathrm{ml}$ \\
\hline Se mezclo hasta obtener una solución homogénea $(\sim 20 \mathrm{~min})$ \\
\hline Glicerol (87\%) & $90 \mathrm{ml}$ \\
Volúmen total: $300 \mathrm{ml}$ \\
\hline \hline
\end{tabular}

Luego se procedió a agregar $10 \mathrm{ml}$ de una solución de equilibrado $\mathrm{N}^{\circ} \mathrm{l}$ (Tabla 6.10) en un tubo de vidrio con tapa a rosca y se colocó la tira cuidando que el gel no quede en contacto con el vidrio. Se incubó en agitación suave (en vaivén) con el tubo bien cerrado durante $15 \mathrm{~min}$.

Tabla 6.10. Componentes de la solución de equilibrado 1 para 6 tiras de isoelectroenfocado.

\begin{tabular}{cc}
\hline \hline \multicolumn{2}{c}{ Solución de equilibrado №1 } \\
\hline Componentes & Cantidad para 6 tiras \\
\hline Ditiotreitol (DTT) & $501 \mathrm{mg}$ \\
\hline Solución base & $60 \mathrm{ml}$ \\
\hline \hline
\end{tabular}

Se enjuagaron las tiras con solución de base y se agregaron $10 \mathrm{ml}$ de la solución de equilibrado №2 (Tabla 6.1 1), colocando la tira con el gel en el lado superior, de forma que no quede en contacto con el vidrio y se incubó en agitación suave durante $15 \mathrm{~min}$. Luego, se enjuagó con la solución base, se escurrió y se 
sembraron las tiras. Para ello se pesó 0,16 g de agarosa NuSIEVE y agregó $20 \mathrm{ml}$ de buffer (Tris $1 \mathrm{M}$ pH 6,8), se fundió $1-2$ min en microondas y se guardó a $55^{\circ} \mathrm{C}$ hasta su uso, las tiras ya equilibradas se colocaron con el extremo positivo hacia la izquierda. Se agregó solución de agarosa embebiendo la tira para ayudarla a descender, de manera que quede en la base del gel asentada y sin burbujas.

Tabla 6.11. Componentes y cantidades para 6 tiras de la solución de equilibrado $\mathrm{N}^{\circ} 2$.

\begin{tabular}{cc}
\hline \multicolumn{2}{c}{ Solución de equilibrado №2 } \\
\hline lodoacetamida & $1,8 \mathrm{~g}$ \\
\hline Solución de base & $60 \mathrm{ml}$ \\
\hline Azul de bromofenol & Punta de espátula \\
\hline \hline
\end{tabular}

\section{$\underline{\text { Migración }}$}

Se utilizó 5,7 I de buffer de corrida 2X (50 mM Tris, 384 mM glicina, 0,2\% SDS $\mathrm{p} / \mathrm{v}$ ). Los mismos se prepararon con $2 \mathrm{~h}$ de anticipación y fueron conservados a $4^{\circ} \mathrm{C}$, para llenar ambos compartimentos: cámara superior ( 1,2 I buffer 2X) y la cámara inferior (4,5I de buffer IX). Se llenó la unidad de electroforesis con los 4,5 I de buffer de corrida IX y se prendió la bomba de la cuba, conectada al baño termostatizado a $16^{\circ} \mathrm{C}$. Se agregó el buffer $2 X$ a este compartimiento y se agregó buffer IX al compartimiento inferior, hasta alcanzar idénticos niveles de buffer en ambas cámaras. Se conectó la cuba a la fuente para comenzar la electroforesis (Figura 6.5).

Tabla 6.12. Condiciones de corrida. Se especifican los dos pasos.

\begin{tabular}{crc}
\hline \multicolumn{4}{c}{ Condiciones de corrida } \\
\hline Paso 1 & $20^{\circ} \mathrm{C}, 10 \mathrm{~mA} /$ gel, durante $1 \mathrm{~h}$ & $60 \mathrm{~mA} \mathrm{p} / 6$ geles \\
\hline Paso 2 & $\begin{array}{c}20^{\circ} \mathrm{C}, 20 \mathrm{~mA} / \mathrm{gel} \text {, durante } 17 \mathrm{~h} \text { o hasta } \\
\text { que el frente de corrida llegue al final del } \\
\text { gel }\end{array}$ & $120 \mathrm{~mA} \mathrm{p} / 6$ geles \\
\hline
\end{tabular}




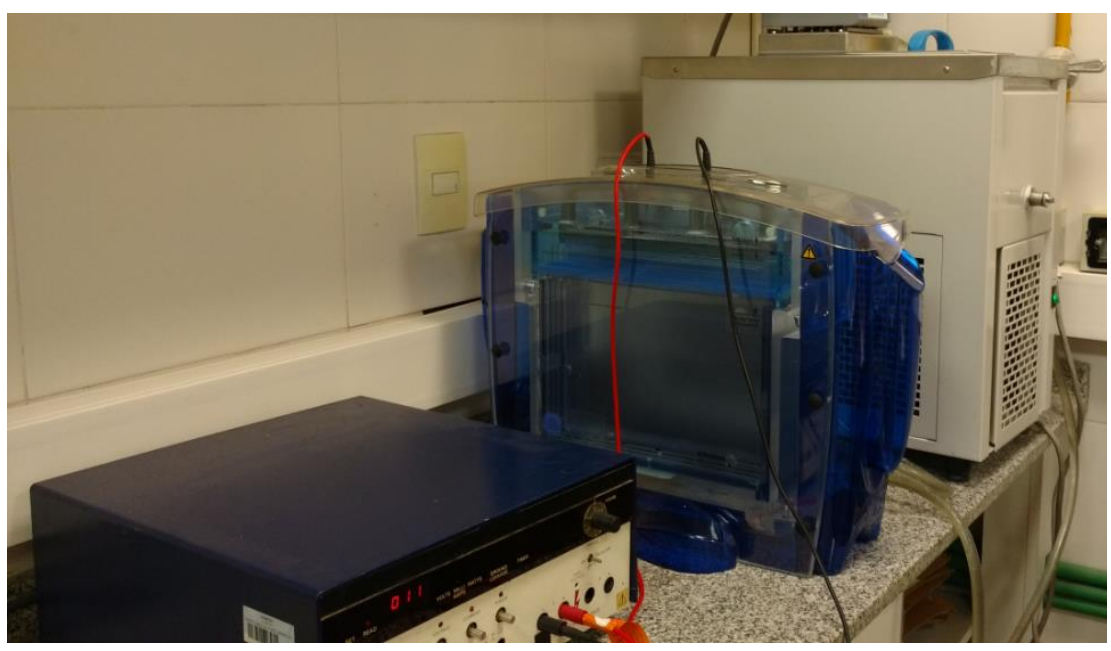

Figura 6.5. Cuba de corrida conectada a la fuente

\section{Recuperación de los geles: coloración/decoloración}

Una vez que el frente de corrida indicado por el azul de bromofenol llegó al final de los vidrios, se detuvo el equipo. Se recuperaron cuidadosamente los geles con ayuda de los soportes planos y se los colocó en los recipientes. Se agregaron aproximadamente $250 \mathrm{ml}$ del colorante Coomassie Blue C250 (Candiano y col., 2004). Se incubó por 1 h (mínimo) en agitación suave y luego se decoloró con agua destilada (3 recambios con intervalos de 30 min cada uno o hasta visualización adecuada de las manchas o spots).

\section{Digitalización de los geles y análisis de datos}

Para el escaneo de los geles se utilizó el Image Scanner III (CE, Health Care, Pittsburgh, EEUU) y se analizaron las diferencias de expresión entre las condiciones de estudio anteriormente descriptas con el programa Prodigy SameSpots version 1.0.3400.25570 (TOTALLAB, Newcastle, Reino Unido). Los geles para cada condición se realizaron por triplicado.

La cuantificación y normalización del volumen de los spots sobre las imágenes digitalizadas de los geles (600 dpi) se realizó utilizando el software Prodigy SameSpots como se mencionó anteriormente. El volumen de cada spot se calculó y normalizó al referir los valores a la suma del volumen total de spots dentro de cada gel. Se aplicó el test de Student para muestras no pareadas. Una proteína fue considerada diferencialmente expresada si el volumen promedio de spots 
normalizados variaba al menos 1,5 veces entre los spots comparados. El efecto fue confirmado por el análisis de varianza a un nivel de significancia de $p<0.05$. Los spots de proteínas que mostraron una variación significativa entre las condiciones estudiadas se recortaron manualmente de los geles utilizando un bisturí. Los mismos fueron colocados en tubos Eppendorfs para su identificación.

El análisis espectrométrico de masas se llevó a cabo en CEQUIBIEM (Facultad de Ciencias Exactas y Naturales, UBA, Buenos Aires, Argentina) y en LIST Instituto de Ciencia y Tecnología de Luxemburgo "Investigación e Innovación Ambiental" "(ERIN), utilizando un espectrómetro de masas en tándem MALDI-TOF / TOF ABI4700 (Applied Biosystems, Foster City, EE. UU.) Grosu-Tudor y col. (2016) y un equipo MALDI 5800 (Sciex, Foster City, EE. UU.), respectivamente.

El software MASCOT (Matrix Science Inc., Boston, MA; http://www.matrixscience.com/search_form_select.html) fue utilizado para analizar los resultados obtenidos en la identificación.

La secuencias de referencias para Ent. mundtii corresponde a la cepa en estudio CRL35 y se encuentra depositada en el CenBank del NCBI bajo el número de acceso JDFTOO000000 descripta en Bonacina y col. (2014).

\section{Análisis Funcional de Interacción de Proteínas sobreexpresadas}

El estudio funcional de las proteínas identificadas y su clasificación en categorías funcionales se realizó con las bases de datos Universal Protein Resource (UniProt) (UniProt, 2015) y COCNITOR para identificar los Clusters de Grupos Ortólogos de proteínas (COG) (Galperin y col., 2015). Para analizar las interacciones entre proteínas de una misma condición que han mostrado expresión diferencial, se realizó un análisis in silico utilizando STRING (Search Tool for the Retrieval of Interacting Genes/Proteins) versión 10.05 disponible públicamente (Szklarczyk y col., 2015). Para cada conjunto de proteinas diferencialmente expresadas, se determinó el número de interacciones proteína-proteína documentadas en la base de datos. Se construyó una red que vincula cada proteína (representadas por nodos) con el resto de las proteínas diferencialmente expresadas en la misma condición. Fue seleccionado 0,4 como nivel de confianza y se utilizaron todos los métodos de predicción disponibles en STRING: interacciones conocidas de bases de datos curadas, interacciones determinadas experimentalmente, interacciones predichas mediante genes vecinos, fusión de genes, 
coocurrencia de genes y otras, como basadas en bibliografía, coexpresión y homología de proteínas. (Szklarczyk y col., 2015). Los resultados arrojados por esta base de datos, fueron incorporados en el software Cytoscape versión 3.6.1 de libre acceso (Shannon y col., 2003), el cual permitió la creación y visualización de nuevas redes de mayor complejidad.

\section{Ensayos de unión a Matriz Extracelular (MEC)}

Se analizó la capacidad de adhesión de Ent. mundtii CRL35 y E. coli NCTC12900 a proteínas de la matriz extracelular cárnica (MEC), según la metodología de Chagnot y col. (2013). Para ello se utilizó colágeno tipo IV (C6745, Sigma Aldrich) y laminina (L2020, Sigma Aldrich). Las condiciones a estudiar fueron las siguientes:

- Unión de ECEH a colágeno IV

- Unión de Ent. mundtii a colágeno IV

- Unión de ECEH + Ent. mundtii a colágeno IV

- Unión de ECEH a laminina

- Unión de Ent. mundtii a laminina

- Unión de ECEH + Ent. mundtii a laminina

Se preparó una solución $50 \mu \mathrm{g} / \mathrm{ml}$ de cada proteína en buffer carbonato 0, $1 \mathrm{M}$ pH 9,6. El ensayo se llevó a cabo utilizando una microplaca de poliestireno de 96 pocillos, en la cual los pocillos se cubrieron con $250 \mu$ le la solución de proteína de MEC que corresponda y los pocillos control con el mismo volumen de solución de BSA (Albúmina Sérica Bovina) 1\% con el objeto de valorar la unión inespecífica que pudiera existir. Se permitió la incubación de la microplaca durante toda la noche a $4^{\circ} \mathrm{C}$ para lograr tapizar el fondo del pocillo con las proteínas utilizadas. Luego se lavaron tres veces los pocillos con $200 \mu$ l de buffer PBST (buffer PBS + Tween 0,05\% $(v / v)$ ) y fueron saturados con $250 \mu$ de solución de BSA al 1\% (w/v) en PBST. Se incubó durante 2 horas a $37^{\circ} \mathrm{C}$ y se lavaron tres veces los pocillos con $200 \mu \mathrm{l}$ de PBST. A continuación se preparó una suspensión de $10^{8} \mathrm{UFC} / \mathrm{ml}$ de cada microorganismo (Ent. mundtii y ECEH) a partir del cultivo correspondiente en fase exponencial. Se agregó a cada suspensión bacteriana cloranfenicol $90 \mu \mathrm{g} / \mathrm{ml}$ con el objeto de prevenir la síntesis de proteínas de novo y el crecimiento bacteriano durante el tiempo del ensayo. Se adicionó en los pocillos $200 \mu$ le la suspensión 
bacteriana de $10^{8} \mathrm{UFC} / \mathrm{ml}$ de Ent. mundtii o ECEH cuando se estudió su capacidad de adhesión de forma individual. En aquellas condiciones donde se estudió la capacidad de adhesión en cocultivo se colocó $100 \mu \mathrm{l}$ de la suspensión $10^{8} \mathrm{UFC} / \mathrm{ml}$ de Ent. mundtii y $100 \mu \mathrm{l}$ de la suspensión $10^{8} \mathrm{UFC} / \mathrm{ml}$ de ECEH, de manera tal que el volumen final sea también $200 \mu$. Se incubó durante $2 \mathrm{~h}$ a $30^{\circ} \mathrm{C}$. Luego se lavó cada pocillo 3 veces con TS (agua triptona) y fueron tratados con $250 \mu$ le Tritón X-100 $0,05 \%$ ( $v / v$ ) para desorber las bacterias y recuperar de esa forma las células adheridas. Se incubó 30 minutos a temperatura ambiente. Luego se extrajo $100 \mu \mathrm{l}$ de cada pocillo y realizaron diluciones seriadas al décimo (1:10). Las diluciones fueron sembradas en placas de agar (MRS y/o LB según corresponda) para recuento bacteriano. Las placas fueron incubadas $18-24$ horas a $30^{\circ} \mathrm{C}$ para luego realizar el recuento bacteriano de células adheridas. El porcentaje de células adheridas se calculó en función de las células totales colocadas, es decir, la cantidad de células adheridas se calculó como el porcentaje de células remanentes con respecto al total agregado a cada pocillo. Cada condición evaluada se realizó por triplicado y el ensayo cuenta con tres replicas biológicas.

\section{Evaluación del efecto inductor de Ent. mundtii CRL35 sobre el fago W933}

Para realizar estos estudios se utilizó la cepa modelo E. coli C600 6 tox (Camage y col., 2003), cedida gentilmente por la Dra. Alison A. Weiss (Departamento de Genética Molecular, Bioquímica y Microbiología, Universidad de Cincinnati, Ohio), en la cual los genes para Stx2 presentes en el fago W933 se reemplazaron por intercambio alélico con los genes que codifican para la proteína verde fluorescente (CFP) y la resistencia al cloranfenicol mediante el uso de secuencias corriente arriba de los genes stx2 (STX2-UP, pb 20467 a 2 1393) y corriente abajo de los genes stx2 (STX2-DOWN, pb 22752 a 23744) en el genoma del fago W933. Por lo tanto, durante la activación del ciclo lítico del fago (proceso llamado Inducción), se produce de manera concomitante, la liberación de partículas virales y la expresión de la proteína verde fluorescente.

Se realizaron dos réplicas biológicas de los siguientes ensayos:

\section{Determinación de la concentración inductora óptima de ciprofloxacina}

Aquella concentración de ciprofloxacina capaz de actuar como agente inductor del fago activando su ciclo lítico, constituyó el control positivo de lisis. Para 
determinar dicha concentración se utilizó un cultivo de toda la noche de E. coli C600ムtox en LB, a partir del cual se preparó $50 \mathrm{ml}$ de una dilución 1/100 del mismo, en presencia de $\mathrm{CaCl}_{2} 10 \mathrm{mM}$ y permitiendo su crecimiento a $37^{\circ} \mathrm{C}$ en agitación hasta lograr una $D_{600}=0.1$. Esto asegura la presencia de un microorganismo en activo crecimiento al momento de recibir el estímulo inductor. Luego, dicha suspensión de E. coli en crecimiento fue distribuida en 5 tubos, conteniendo $5 \mathrm{ml}$ del cultivo cada uno, a los cuales se adicionó ciprofloxacina en cantidad necesaria para obtener una concentración final de: 7.5, 15, 30, 60 y 120 ng/ml. Se trabajó con una solución stock $10 \mu \mathrm{g} / \mathrm{ml}$ de ciprofloxacina. Dichos tubos fueron incubados a $37^{\circ} \mathrm{C}$ en agitación hasta observar visualmente franca lisis del microorganismo.

\section{Estudio de Ent. mundtii CRL35 como agente inductor}

Se evaluó el rol de Ent. mundtii como potencial agente inductor del fago W933 presente en la cepa C600ムtox mediante la detección de partículas virales y evidencia de lisis de E. coli C600 4 tox cuando crece en presencia de la cepa láctica.

Se llevó a cabo un proceso de inducción según la metodología de Camage y col. (Camage y col., 2003) con algunas modificaciones. A partir de un cultivo toda la noche de E. coli C600 6 tox se prepararon $20 \mathrm{ml}$ de una dilución 1/100 en LB con el agregado de $\mathrm{CaCl}_{2} 10 \mathrm{mM}$. Se incubó a $37^{\circ} \mathrm{C}$ en agitación durante I hora hasta llegar a $\mathrm{DO}_{600}=0.1$. Dicho cultivo en crecimiento activo fue dividido en tres tubos, conteniendo $5 \mathrm{ml}$ cada uno, los cuales recibieron los siguientes tratamientos: 1) sin adición de agentes inductores (control negativo de inducción), 2) adición de ciprofloxacina $60 \mathrm{ng} / \mathrm{ml}$ (control positivo de inducción), 3) adición de Ent. mundtii CRL35 ( $\left.10^{7} \mathrm{UFC} / \mathrm{ml}\right)$. Los mismos fueron incubados a $37^{\circ} \mathrm{C}$ en agitación durante 24 h. Para cada tratamiento se tomaron muestras a las 0, 1, 2, 3, 4 y 5 horas de incubación a partir de las cuales se realizó análisis de la viabilidad de ambos grupos microbianos utilizando medios agarizados selectivos. Para el recuento bacteriano, se prepararon diluciones decimales y se plaquearon en el medio correspondiente, agar MRS para LAB y agar Mac Conkey (Britania, Buenos Aires, Argentina) para E. coli, y se incubaron a $30^{\circ} \mathrm{C}$ durante 48 y 24 h, respectivamente. Además, a las 4 y 24 h de incubación, se tomaron $2 \mathrm{ml}$ de cada tratamiento y fueron centrifugados a $5000 \mathrm{rpm}$ durante 15 minutos. El sobrenadante obtenido, conteniendo las partículas virales, se esterilizó por filtración a través de un filtro de 0,22 um (diámetro del poro) y se almacenó a $4^{\circ} \mathrm{C}$ para su posterior titulación. 


\section{Titulación del fago W933}

La titulación de las partículas virales producidas durante el proceso de inducción se llevó a cabo según Gamage y col. (2003). Se preparó una dilución 1/100 en LB a partir de un cultivo de toda la noche de la cepa E. coli B la cual funciona como cepa indicadora por ser sensible a la infección con el fago W933. Se permitió el crecimiento de dicha suspensión bacteriana hasta alcanzar una $D_{600}=0.5$. Luego se adicionó $200 \mu$ del cultivo activo de E. coli B y $30 \mu$ l solución stock $1 \mathrm{M}$ de $\mathrm{CaCl}_{2}$ (concentración final $10 \mathrm{mM}$ ) a $3 \mathrm{ml}$ de $\mathrm{LB}$ blando $(0,7 \%$ agar) fundido y mantenido a $45^{\circ} \mathrm{C}$. Esta mezcla se homogenizó y se vertió inmediatamente sobre una placa conteniendo LB agar solidificado. Se dejó solidificar la capa superior que contendrá el césped del microorganismo indicador ( $E$. coli B). Paralelamente se realizaron diluciones al décimo de cada uno de los sobrenadantes obtenidos anteriormente durante el proceso de inducción. Se colocó sobre el agar ya solidificado una gota $(5 \mu \mathrm{l})$ de cada dilución. Las placas se incubaron a $37^{\circ} \mathrm{C}$ durante toda la noche para luego realizar el recuento de las placas de lisis. Se determinó el número de unidades formadoras de placa (UFP) por mililitro mediante la siguiente fórmula:

UFP/ml= número de placas de lisis/volumen de inóculo $x$ dilución

\section{Influencia del cocultivo con ECEH en la producción de bacteriocina por Ent. mundtii CRL35: titulación de enterocina CRL35}

Esta técnica permite la detección de la actividad antimicrobiana del sobrenadante de cultivo correspondiente a la presencia de enterocina CRL35 frente a un microorganismo indicador (Listeria monocytogenes FBUNT). La actividad se detecta mediante la formación de un halo de inhibición del crecimiento del microorganismo indicador dado por la difusión de la bacteriocina (Saavedra, 2004). Mediante esta técnica se determinó la actividad antimicrobiana del sobrenadante de cultivo obtenido por centrifugación ( 12.200 xg 10 min) de Ent. mundtii creciendo en SCM de forma individual y en cocultivo con ECEH a T1 y T2. Brevemente, se preparan diluciones seriadas (1:2) del sobrenadante libre de células. Se mezcla 10 $\mu$ de un cultivo toda la noche de la cepa indicadora ( $1 \times 108 \mathrm{UFC} / \mathrm{ml})$ con $10 \mathrm{ml}$ de TSB agar blando $(0,7 \%$ agar $\mathrm{p} / \mathrm{v})$ atemperado a $45^{\circ} \mathrm{C}$ y se agrega sobre la 
superficie de una placa de Petri que contiene $10 \mathrm{ml}$ de TSB agar 1,5\% sólido. Una vez solidificada esta capa de agar blando (aprox. $15 \mathrm{~min}$ ) se realizan orificios de $5 \mathrm{~mm}$ con sorbetes estériles y se siembran en cada uno de ellos $30 \mu \mathrm{l}$ de las diluciones realizadas. Se incuban las placas sin invertir por $24 \mathrm{~h}$ a $37^{\circ} \mathrm{C}$.

El título de la bacteriocina se expresa como unidades arbitrarias por $\mathrm{ml}(\mathrm{UA} / \mathrm{ml})$ y se calcula de acuerdo con la fórmula:

$$
\frac{U A}{m l}=\frac{1}{m l \text { sembrados }} \times \text { inversa de la máxima dilución con actividad }
$$




\section{INTERACCIONES MICROBIANAS EN CONDICIONES TECNOLÓGICAS}

\section{Procesado y obtención de carne molida}

Se trabajó con una pieza de carne vacuna de $5 \mathrm{~kg}$ de origen comercial, la cual fue procesada en condiciones asépticas (con guantes en flujo laminar). Previo a su utilización tanto la superficie de los materiales utilizados como la superficie de la pieza de carne fueron rociadas con alcohol $96^{\circ}$ y secadas en flujo laminar. Luego se sometieron a radiación ultravioleta durante 15 minutos. La pieza de carne se colocó sobre una tabla para su procesamiento. Utilizando un bisturí estéril y regularmente flameado, se descartó la capa superior de carne (aproximadamente 2 $\mathrm{cm}$ de capa superficial). La pieza de carne restante se cortó en pequeños trozos con bisturí, y fueron colocados en el recipiente de una procesadora de cocina. Dichos trozos se procesaron hasta obtener carne suficientemente triturada, símil carne molida (CM). Este proceso de triturado se repitió hasta agotar la pieza de carne. La carne ya triturada de colocó en bolsas de muestreo estériles, conteniendo cada una de ellas aproximadamente 200 gramos de carne (se realizó la pesada en flujo). Se tomó una pequeña cucharada de carne de cada bolsa fraccionada y se colocó en una bolsa de Stomacher estéril. Se agregó solución fisiológica para obtener una dilución 1/10 de la muestra (ejemplo: a 5 gramos de carne pesadas se agrega solución fisiológica hasta obtener 50 gramos de peso). La muestra se homogeneizó mediante Stomacher, Stomacher 400 (Stomacher, Londres, Reino Unido) durante 2 ciclos de $120 \mathrm{~s}$. Del extracto obtenido se realizaron diluciones al décimo en solución fisiológica que fueron sembradas en medio PCA agarizado a fin de obtener un recuento basal de la microbiota presente. Se incubaron las placas a $30^{\circ} \mathrm{C}$ durante 48 h. Finalmente las bolsas conteniendo la carne molida fueron selladas bajo vacío (Selladora de polietileno por impulso Lipari C 400 ) y almacenadas a $-20^{\circ} \mathrm{C}$ hasta su utilización. 


\section{Estudios fisiológicos en carne molida}

Se descongelaron las bolsas de carne molida necesarias según los lotes a estudiar (50 gr/lote). Se pesaron asépticamente porciones de 50 gr de carne molida para cada lote y se colocaron en bolsas de muestreo. Cada bolsa con $50 \mathrm{gr}$ de carne fue inoculada con $5 \mathrm{ml}$ de solución fisiológica conteniendo el inóculo (UFC/gr carne) correspondiente según la condición a estudiar (ver Tabla 6.13). Además a cada lote se agregó $5 \mathrm{ml}$ de solución de glucosa 0,5\% (p/v). Se mezcló manualmente la carne inoculada para permitir el íntimo contacto entre el inóculo y la carne. Los diferentes lotes fueron incubados a $16^{\circ} \mathrm{C}$ durante $72 \mathrm{~h}$. En los tiempos T 0, 7, 24, 48, $72 \mathrm{~h}$ se tomaron asépticamente $5 \mathrm{gr}$ de carne de cada lote y se colocaron en una nueva bolsa estéril para Stomacher, agregando solución fisiológica hasta lograr dilución 1/10. Cada muestra luego se pasó por el digestor (Stomacher Blender, UK) en 2 ciclos de 1 minuto cada uno. Se tomaron $3 \mathrm{ml}$ de la muestra homogeneizada, se colocaron en recipiente adecuado y realizó medición de pH en pHmeter Altronix TPX I (Nueva York, EE. UU.).A partir del homogeneizado (el cual constituye la primera dilución de la muestra) se realizaron diluciones $1 / 10$ en solución fisiológica y $20 \mu \mathrm{l}$ de cada dilución fueron sembrados por duplicado en medios de cultivos agarizados, aplicando el método de la gota (Miles y col., 1938). Los medios de cultivo utilizados fueron agar Mac Conkey Sorbitol para ECEH, MRS para Ent. mundtii y PCA como control para el recuento de mesófilos totales. Las placas fueron incubadas a $30^{\circ} \mathrm{C}$ durante $24 \mathrm{~h}$. Se realizó finalmente recuento bacteriano.

Tabla 6.13. Se detalla la carga microbiana y el tiempo de inoculación para cada lote de carne molida estudiado. TO: inoculación al inicio de incubación. T6: inoculación luego de 6 horas de incubación a $16^{\circ} \mathrm{C}$.

\begin{tabular}{|c|c|c|}
\hline $\mathrm{N}^{\circ}$ lote & Lotes & Inóculo (UFC/gr) \\
\hline 1 & Control & Sin inóculo \\
\hline 2 & $\begin{array}{l}\text { ECEH } \\
\text { crecimiento individual }\end{array}$ & TO: $10^{4}$ \\
\hline 3 & $\begin{array}{l}\text { Ent. mundtii } \\
\text { crecimiento individual }\end{array}$ & TO: $10^{7}$ \\
\hline 4 & $\begin{array}{l}\text { Cocultivo - } \\
\text { Efecto competitivo }\end{array}$ & TO: $10^{7}$ Ent. mundtii + $10^{4}$ EHEC \\
\hline 5 & $\begin{array}{l}\text { Cocultivo - } \\
\text { Efecto preventivo }\end{array}$ & $\begin{array}{l}\text { TO: } 10^{7} \text { Ent. mundtii } \\
\text { T6: } 10^{4} \text { EHEC }\end{array}$ \\
\hline 6 & $\begin{array}{l}\text { Cocultivo - } \\
\text { Efecto desplazamiento }\end{array}$ & $\begin{array}{l}\text { TO: } 10^{4} \text { EHEC } \\
\text { T6: } 10^{7} \text { Ent. mundtii }\end{array}$ \\
\hline
\end{tabular}




\section{BIBLIOGRAFÍA}
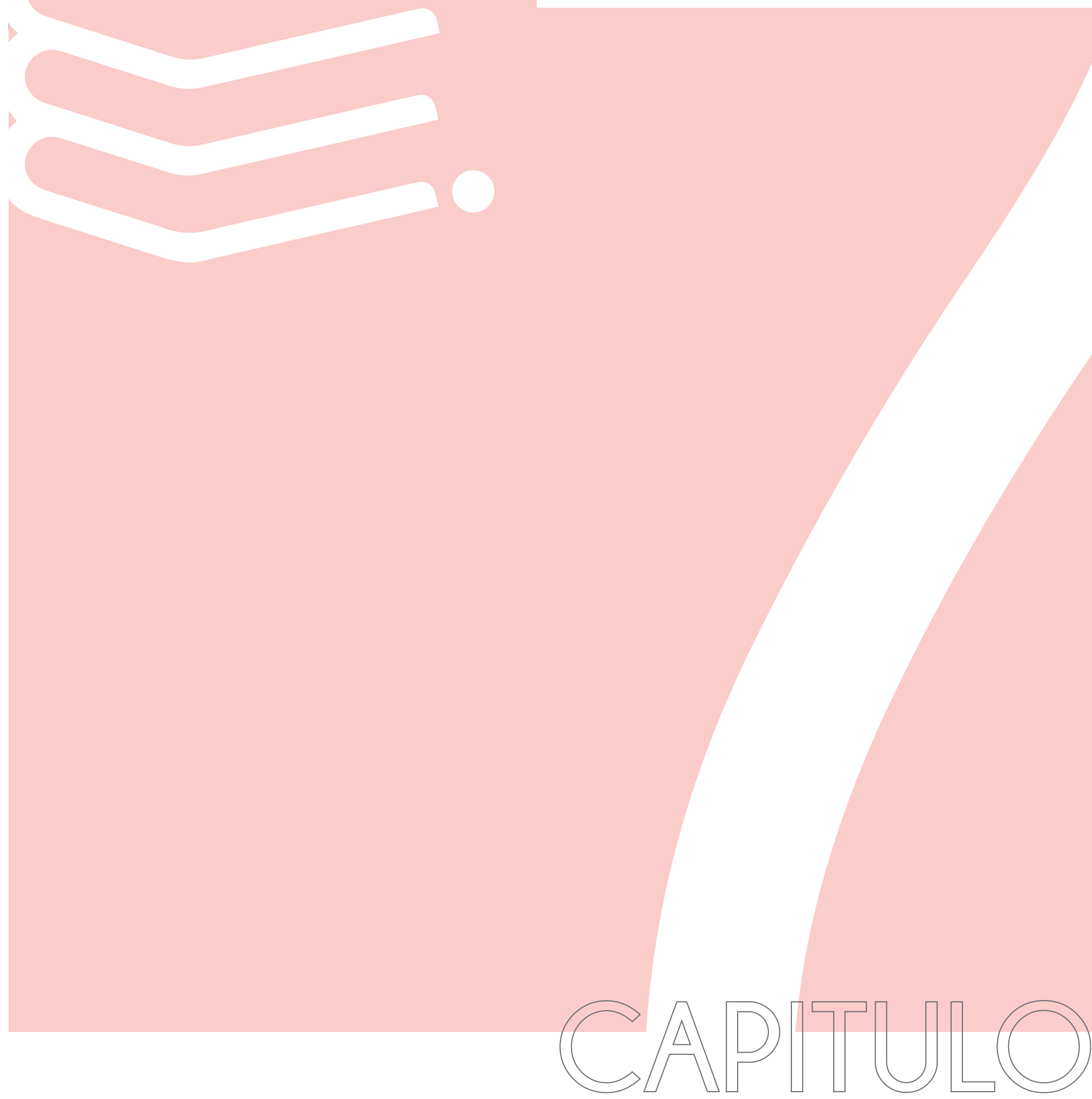


\section{CAPÍTULO 7 BIBLIOGRAFÍA}

\section{A}

Acuña, L., Corbalan, N.S., Fernandez-No, I.C., Morero, R.D., Barros-Velazquez, J. y Bellomio, A. (2015). "Inhibitory effect of the hybrid bacteriocin Ent35-MccV on the growth of Escherichia coli and Listeria monocytogenes in model and food systems". Food and Bioprocess Technology 8, 1063-1075.

Aguilera, J. y Chirife, J. (1994). "Combined methods for the preservation of foods in Latin America and the CYTED-D project," in Water in Foods. Elsevier, 433-444.

Angmo, K., Kumari, A. y Bhalla, T.C. (2016). "Antagonistic activities of lactic acid bacteria from fermented foods and beverage of Ladakh against Yersinia enterocolitica in refrigerated meat". Food Bioscience 13, 26-31.

Atassi, F. y Servin, A.L. (2010). "Individual and co-operative roles of lactic acid and hydrogen peroxide in the killing activity of enteric strain Lactobacillus johnsonii NCC933 and vaginal strain Lactobacillus gasseri KS120 1 against enteric, uropathogenic and vaginosis-associated pathogens". FEMS microbiology letters $304,29-38$.

Ausubel, F. (1999). "Current Protocols in Molecular Biology" (Ausubel, FM, Brent, R., Kingston, RE, Moore, DD, Seidman, JG, Smith, JA, and Struhl, K., eds) John Wiley \& Sons. Inc, New York.

Ayaz, N.D., Gencay, Y.E. y Erol, I. (2014). "Prevalence and molecular characterization of sorbitol fermenting and non-fermenting Escherichia coli $\mathrm{O} 157: \mathrm{H} 7+/ \mathrm{H} 7$-isolated from cattle at slaughterhouse and slaughterhouse wastewater". International Journal of Food Microbiology 174, 31-38.

B

Bae, Y.M., Yoon, J.H., Kim, J.Y. y Lee, S.Y. (2018). "Identifying the mechanism of Escherichia coli O 157: $\mathrm{H} 7$ survival by the addition of salt in the treatment with organic acids". Journal of Applied Microbiology 124, 24 1-253.

Baillo, A.A. (2018). "Interacción entre Bacterias Lácticas y Escherichia coli enterohemorrágica: estudios fisiológicos y moleculares". Tesis de grado, UNT.

Barco, L., Belluco, S., Roccato, A. y Ricci, A. (2015). "A systematic review of studies on Escherichia coli and Enterobacteriaceae on beef carcasses at the slaughterhouse". International Journal of Food Microbiology 207, 30-39. 
Bearson, B.L., Lee, I.S. y Casey, T.A. (2009). “Escherichia coli O 157:H7 glutamate- and arginine-dependent acid-resistance systems protect against oxidative stress during extreme acid challenge". Microbiology 155, 805-812.

Belfiore, C., Castellano, P. y Vignolo, G. (2007). "Reduction of Escherichia coli population following treatment with bacteriocins from lactic acid bacteria and chelators". Food Microbiology 24, 223-229.

Benedict, R., Schultz, F. y Jones, S. (1990). "Attachment and removal of Salmonella spp. on meat and poultry tissues". Journal of Food Safety 11, 135-148.

Best, A., La Ragione, R.M., Cooley, W.A., O'connor, C.D., Velge, P. y Woodward, M.J. (2003). "Interaction with avian cells and colonisation of specific pathogen free chicks by Shiga-toxin negative Escherichia coli O 157:H7 (NCTC 12900)". Vet Microbiol 93, 207-222.

Bi, X., Wang, Y., Hu, X. y Liao, X. (2017). "iTRAQ-Based Proteomic analysis of sublethally injured Escherichia coli O 157: H7 cells induced by high pressure carbon dioxide". Frontiers in microbiology 8, 2544.

Bolton, D.J., Doherty, A.M. y Sheridan, J.J. (2001). "Beef HACCP: intervention and nonintervention systems". International Journal of Food Microbiology 66, 119-129.

Bonacina, J. (2017). "Genomic and functional analysis of enterococci isolated from food". Tesis Doctoral, Universidad Nacional de Tucumán.

Bonacina, J., Saavedra, L., Suarez, N.E. y Sesma, F. (2014). "Draft genome sequence of the nonstarter bacteriocin-producing strain Enterococcus mundtii CRL35". Genome Announc 2.

Boontim, N., Khanongnuch, C., Pathom-Aree, W., Niamsup, P. y Lumyong, S. (2018). "Production of L-lactic acid by thermotorelant lactic acid bacteria". Chiang Mai Journal of Science 45, 68-76.

Branchu, P., Matrat, S., Vareille, M., Garrivier, A., Durand, A., Crépin, S., Harel, J., Jubelin, G. y Gobert, A.P. (2014). "NsrR, GadE, and GadX interplay in repressing expression of the Escherichia coli O 157: H7 LEE pathogenicity island in response to nitric oxide". PLoS pathogens 10, e 1003874.

C

Candiano, G., Bruschi, M., Musante, L., Santucci, L., Ghiggeri, G.M., Carnemolla, B., Orecchia, P., Zardi, L. y Righetti, P.G. (2004). "Blue silver: a very sensitive colloidal Coomassie G-250 staining for proteome analysis". Electrophoresis 25, 1327-1333.

Caprioli, A., Morabito, S., Brugère, H. y Oswald, E. (2005). "Enterohaemorrhagic Escherichia coli: emerging issues on virulence and modes of transmission". Veterinary research $36,289-311$.

Carlson, B.A., Ruby, J., Smith, G.C., Sofos, J.N., Bellinger, G.R., Warren-Serna, W., Centrella, B., Bowling, R.A. y Belk, K.E. (2008). "Comparison of antimicrobial efficacy of multiple 
beef hide decontamination strategies to reduce levels of Escherichia coli 0157 : H7 and Salmonella". Journal of Food Protection 7 1, 2223-2227.

Castaldo, C., Vastano, V., Siciliano, R.A., Candela, M., Vici, M., Muscariello, L., Marasco, R. y Sacco, M. (2009). "Surface displaced alfa-enolase of Lactobacillus plantarum is a fibronectin binding protein". Microbial Cell Factories 8, 14.

Castellano, P., Belfiore, C. y Vignolo, G. (2011). "Combination of bioprotective cultures with EDTA to reduce Escherichia coli O157: H7 in frozen ground-beef patties". Food Control 22, 1461-1465.

Castellano, P., Gonzalez, C., Carduza, F. y Vignolo, G. (2010). "Protective action of Lactobacillus curvatus CRL705 on vacuum-packaged raw beef. Effect on sensory and structural characteristics". Meat Sci 85, 394-401.

Castellano, P., Pérez lbarreche, M., Blanco Massani, M., Fontana, C. y Vignolo, G. (2017). "Strategies for pathogen biocontrol using lactic acid bacteria and their metabolites: a focus on meat ecosystems and industrial environments". Microorganisms 5, 38.

Castellano, P., Raya, R. y Vignolo, G. (2003). "Mode of action of lactocin 705, a twocomponent bacteriocin from Lactobacillus casei CRL705". International Journal of Food Microbiology 85, 35-43.

Castellano, P. y Vignolo, G. (2006). "Inhibition of Listeria innocua and Brochothrix thermosphacta in vacuum-packaged meat by addition of bacteriocinogenic Lactobacillus curvatus CRL705 and its bacteriocins". Letters in Applied Microbiology 43, 194-199.

Cohen, D.P., Renes, J., Bouwman, F.G., Zoetendal, E.G., Mariman, E., De Vos, W.M. y Vaughan, E.E. (2006). "Proteomic analysis of log to stationary growth phase Lactobacillus plantarum cells and a 2-DE database". Proteomics 6, 6485-6493.

Cortés-Sánchez, A.D.J. y Salgado-Cruz, M.D.L.P. (2017). "Escherichia coli O 157: H7 in the context of foodborne diseases and public health". Environmental and Experimental Biology 15, 191-200.

Chagnot, C., Agus, A., Renier, S., Peyrin, F., Talon, R., Astruc, T. y Desvaux, M. (2013). “In vitro colonization of the muscle extracellular matrix components by Escherichia coli O 157: $\mathrm{H7}$ : the influence of growth medium, temperature and $\mathrm{pH}$ on initial adhesion and induction of biofilm formation by collagens I and III". PLOS One 8, e59386.

Chaillou, S., Champomier-Vergès, M.-C., Cornet, M., Crutz-Le Coq, A.-M., Dudez, A.-M., Martin, V., Beaufils, S., Darbon-Rongère, E., Bossy, R. y Loux, V. (2005). "The complete genome sequence of the meat-borne lactic acid bacterium Lactobacillus sakei 23K". Nature biotechnology 23, 1527-1533.

Chalón, M.C., Acuña, L., Morero, R.D., Minahk, C.J. y Bellomio, A. (2012). “Membrane-active bacteriocins to control Salmonella in foods: Are they the definite hurdle?". Food Research International 45, 735-744. 
Champomier-Vergès, M.-C., Zagorec, M. y Fadda, S. (2010). "Proteomics: A Tool for Understanding Lactic Acid Bacteria Adaptation to Stressful Environments," in Biotechnology of Lactic Acid Bacteria. Novel Applications, ed. Raúl Ricardo Raya Fernanda Mozzi, Graciela M. Vignolo. (2121 State Avenue, Ames, lowa 500148300, USA), 57-72.

D

Daegelen, P., Studier, F.W., Lenski, R.E., Cure, S. y Kim, J.F. (2009). "Tracing ancestors and relatives of Escherichia coli B, and the derivation of B strains REL606 and BL21 (DE3)". Journal of Molecular Biology 394, 634-643.

De Angelis, M., Calasso, M., Cavallo, N., Di Cagno, R. y Gobbetti, M. (2016). "Functional proteomics within the genus Lactobacillus". Proteomics 16, 946-962.

De Man, J., Rogosa, D. y Sharpe, M.E. (1960). "A medium for the cultivation of lactobacilli". Journal of Applied Microbiology 23, 130-135.

Delahay, R.M., Frankel, G. y Knutton, S. (2001). "Intimate interactions of enteropathogenic Escherichia coli at the host cell surface". Current Opinion in Infectious Diseases 14, 559-565.

Doulgeraki, A.l., Ercolini, D., Villani, F. y Nychas, G.-J.E. (2012). "Spoilage microbiota associated to the storage of raw meat in different conditions". International Journal of Food Microbiology 157, 130-141.

Durruthy, J.C., Pérez, M.C.L., Suárez, Y.B., Hinojosa, M.R. y Reyes, I.E. (2018). "Problemas medioambientales y transmisión de enfermedades por alimentos". Revista de Información Científica 97, 387-397.

E

Efsa (2004). "Opinion of the Scientific Panel on Biological Hazards on a request from the Commission related to the use of vaccines for the control of Salmonella in poultry". The EFSA Journal 114, 1-74.

Eymann, A., Coccia, P., Raddavero, C., Lafi, G., Ferraris, V., Ramírez, J. y Ferraris, J. (2016). "Prevalence and clinical course of typical hemolytic uremic syndrome among siblings". Archivos argentinos de pediatria 114, 553-556.

F

Fadda, S., Lopez, C. y Vignolo, G. (2010). "Role of lactic acid bacteria during meat conditioning and fermentation: peptides generated as sensorial and hygienic biomarkers". Meat Sci 86, 66-79.

Fadda, S., Saavedra, L., Belfiore, C. y Vignolo, G. (2012). "Lactic Acid Bacteria in Meat and Fish" in New Approaches for Traditional Applications Lactobacillus: Classification, Uses and Health Implications, eds. Perez Campos Alba I. y Mena Arturo Leon. Nova Publishers), 147-176. 
Fadda, S., Sanz, Y., Vignolo, G., Aristoy, M., Oliver, G. y Toldra, F. (1999). "Hydrolysis of pork muscle sarcoplasmic proteins by Lactobacillus curvatus and Lactobacillus sakei". Applied and Environmental Microbiology 65, 578-584.

Fadda, S., Vignolo, G., Holgado, A.P. y Oliver, G. (1998). "Proteolytic activity of Lactobacillus strains isolated from dryfermented sausages on muscle sarcoplasmic proteins". Meat Science 49, $11-18$.

Farias, M., Farías, R., Holgado, A.D.R. y Sesma, F. (1996). "Purification and N-terminal amino acid sequence of Enterocin CRL 35, a 'pediocin-like'bacteriocin produced by Enterococcus faecium CRL 35". Letters in Applied Microbiology 22, 417-419.

Fernández-Brando, R.J., Bentancor, L.V., Mejías, M.P., Panek, A.C., Cabrera, G.G., Exeni, R.A. y Palermo, M.S. (2011). “Actualización en el tratamiento del síndrome urémico hemolítico endémico: Patogénesis y tratamiento de la complicación sistémica más grave de las infecciones por Escherichia coli productor de toxina Shiga". Medicina (Buenos Aires) 71, 383-389.

Frank, J.F. (2001). "Microbial attachment to food and food contact surfaces". Advances in Food and Nutrition Research 43, 319-370.

Fraser, M.E., Fujinaga, M., Cherney, M.M., Melton-Celsa, A.R., Twiddy, E.M., O'brien, A.D. y James, M.N. (2004). "tructure of Shiga toxin type 2 (Stx2) from Escherichia coli O 157:H7". Journal of Biological Chemistry.

Fratamico, P.M., Schultz, F.J., Benedict, R.C., Buchanan, R.L. y Cooke, P.H. (1996). "Factors influencing attachment of Escherichia coli O157:H7 to beef tissues and removal using selected sanitizing rinses". Journal of Food Protection 59, 453-459.

G

Galperin, M.Y., Makarova, K.S., Wolf, Y.I. y Koonin, E.V. (2015). "Expanded microbial genome coverage and improved protein family annotation in the COG database". Nucleic Acids Research 43, D261-269.

Gamage, S.D., Strasser, J.E., Chalk, C.L. y Weiss, A.A. (2003). "Nonpathogenic Escherichia coli can contribute to the production of Shiga toxin". Infection and Immunity 71 , 3107-3115.

Garcia-Gonzalez, L., Geeraerd, A.H., Spilimbergo, S., Elst, K., Van Ginneken, L., Debevere, J., Van Impe, J. y Devlieghere, F. (2007). "High pressure carbon dioxide inactivation of microorganisms in foods: the past, the present and the future". International Journal of Food Microbiology 1 17, 1-28.

García, A., Fox, J.G. y Besser, T.E. (2010). "Zoonotic enterohemorrhagic Escherichia coli: a One Health perspective". ILAR journal 51, 221-232.

Giannakourou, M., Koutsoumanis, K., Nychas, G. y Taoukis, P. (2001). "Development and assessment of an intelligent shelf life decision system for quality optimization of the food chill chain". Journal of Food Protection 64, 1051-1057. 
Gil, C. y Monteoliva, L. (2014). "Trends in microbial proteomics". Journal of Proteomics 97, 1-2.

Goh, S., Newman, C., Knowles, M., Bolton, F., Hollyoak, V., Richards, S., Daley, P., Counter, D., Smith, H. y Keppie, N. (2002). "E. coli O 157 phage type 21/28 outbreak in North Cumbria associated with pasteurized milk". Epidemiology \& Infection 129, 451-457.

Graham, C.U. (1996). "The SOS response of Escherichia coli". Escherichia coli and Salmonella. Cellular and molecular biology, 1400-1416.

Graham, R.L., Graham, C. y Mcmullan, G. (2007). “Microbial proteomics: a mass spectrometry primer for biologists". Microbial Cell Factories 6, 26.

Grosu-Tudor, S.-S., Brown, L., Hebert, E.M., Brezeanu, A., Brinzan, A., Fadda, S., Mozzi, F. y Zamfir, M. (2016). "S-layer production by Lactobacillus acidophilus IBB 801 under environmental stress conditions". Applied Microbiology and Biotechnology 100, 4573-4583.

$\mathrm{H}$

Hebert, E.M., Saavedra, L., Taranto, M.P., Mozzi, F., Magni, C., Nader, M.E., Font De Valdez, G., Sesma, F., Vignolo, G. y Raya, R.R. (2012). "Genome sequence of the bacteriocinproducing Lactobacillus curvatus strain CRL705". Journal of Bacteriology 194, 538-539.

$\mathrm{J}$

Jeffery, C.J. (2015). “Why study moonlighting proteins?" Frontiers in Genetics 6.

Jin, L., Marquardt, R. y Zhao, X. (2000). "A strain of Enterococcus faecium (18C23) inhibits adhesion of enterotoxigenic Escherichia coli K88 to porcine small intestine mucus". Applied and Environmental Microbiology 66, 4200-4204.

Johansen, B.K., Wasteson, Y., Granum, P.E. y Brynestad, S. (2001). "Mosaic structure of Shigatoxin-2-encoding phages isolated from Escherichia coli O157: H7 indicates frequent gene exchange between lambdoid phage genomes". Microbiology 147, 1929-1936.

Jordan, K., Dalmasso, M., Zentek, J., Mader, A., Bruggeman, G., Wallace, J., De Medici, D., Fiore, A., Prukner-Radovcic, E. y Lukac, M. (2014). "Microbes versus microbes: control of pathogens in the food chain". Journal of the Science of Food and Agriculture 94, 3079-3089.

K

Kassem, A., Meade, J., Gibbons, J., Mcgill, K., Walsh, C., Lyng, J. y Whyte, P. (2017). "Evaluation of chemical immersion treatments to reduce microbial populations in fresh beef". International Journal of Food Microbiology 261, 19-24.

Kjos, M., Nes, I.F. y Diep, D.B. (2009). “Class II one-peptide bacteriocins target a phylogenetically defined subgroup of mannose phosphotransferase systems on sensitive cells". Microbiology 155, 2949-2961. 
Kocharunchitt, C., King, T., Gobius, K., Bowman, J.P. y Ross, T. (2012). "Integrated transcriptomic and proteomic analysis of the physiological response of Escherichia coli O 157: H7 Sakai to steady-state conditions of cold and water activity stress". Molecular \& Cellular Proteomics 11, M111.009019.

Koistinen, K.M., Plumed-Ferrer, C., Lehesranta, S.J., Karenlampi, S.O. y Von Wright, A. (2007). "Comparison of growth-phase-dependent cytosolic proteomes of two Lactobacillus plantarum strains used in food and feed fermentations". FEMS Microbiology Letters $273,12-21$.

Konowalchuk, J., Speirs, J. y Stavric, S. (1977). "Vero response to a cytotoxin of Escherichia coli". Infection and Immunity 18, 775-779.

Koutsoumanis, K., Stamatiou, A., Skandamis, P. y Nychas, G.-J. (2006). “Development of a microbial model for the combined effect of temperature and $\mathrm{pH}$ on spoilage of ground meat, and validation of the model under dynamic temperature conditions". Applied and Environmental Microbiology 72, 124-134.

L

Laciar, A.L., Ruiz, M.L.V. y Le Monnier, A. (2011). "Neonatal Listeria-meningitis in San Luis, Argentina: a three-case report". Revista Argentina de Microbiología 43, 45-47.

Leistner, L. (1978). Hurdle effect and energy saving. Food quality and nutrition, 553-557.

Leistner, L. (1994). "Food design by hurdle technology and HACCP". Adalbert-RapsFoundation.

Leistner, L. (1995). "Principles and applications of hurdle technology" in New methods of food preservation. ed. G. W. Gould. Springer, Boston, MA 1-21.

Leistner, L. (1999). "Combined methods for food preservation". Food Science And Technology-New York-Marcel Dekker-, 457-486.

Lezzi, S., Sallovitz, J.M. y Purslow, P. (2016). "Eficacia de la aspersión de ácido láctico (4\%) en el descenso de enterobacterias totales y Escherichia coli en reses bovinas". Revista veterinaria 27, 41-44.

Liebler, D. (2002). "Introduction to Proteomics: Tools for the new biology". Totowa, NJ: Humana Press, Inc.

Lilley, K.S., Razzaq, A. y Dupree, P. (2002). "Two-dimensional gel electrophoresis: recent advances in sample preparation, detection and quantitation". Current Opinion in Chemical Biology 6, 46-50.

Lim, J.Y., Yoon, J. y Hovde, C.J. (2010). "A brief overview of Escherichia coli O 157:H7 and its plasmid O 157". Journal of Microbiology and Biotechnology 20, 5-14.

M

Macfaddin, J. (1985). "Mannitol salt agar (MSA). Media for isolation-cultivationidentification-maintenance of medical bacteria". Baltimore: Williams \& Wilkins, 483486. 
Magasanik, B. y Rothstein, D.M. (2012). "The Role of Glutamine Synthetase in the Regulation of Bacterial Nitrogen Metabolism," in Glutamine: metabolism, enzymology, and regulation, eds. Jaime Mora y Rafael Palacios. (Mexico: Elsevier).

Masana, M.O., Barrio, Y.X., Palladino, P.M., Sancho, A.M. y Vaudagna, S.R. (2015). "High pressure treatments combined with sodium lactate to inactivate Escherichia coli O 157:H7 and spoilage microbiota in cured beef carpaccio". Food microbiology $46,610-617$.

Mataragas, M., Drosinos, E., Vaidanis, A. y Metaxopoulos, I. (2006). "Development of a predictive model for spoilage of cooked cured meat products and its validation under constant and dynamic temperature storage conditions". Journal of Food Science 71, M157-M167.

Mehr, K.S., Mousavi, S.L., Rasooli, I., Amani, J. y Rajabi, M. (2012)."A DNA Vaccine against Escherichia coli O 157:H7". Iranian Biomedical Journal 16, 133.

Miles, A.A., Misra, S. y Irwin, J. (1938). "The estimation of the bactericidal power of the blood". Epidemiology \& Infection 38, 732-749.

Moghimi, R., Ghaderi, L., Rafati, H., Aliahmadi, A. y Mcclements, D.J. (2016). “Superior antibacterial activity of nanoemulsion of Thymus daenensis essential oil against $E$. coli". Food Chemistry 194, 410-415.

Mukherjee, J., Chios, K., Fishwild, D., Hudson, D., O'donnell, S., Rich, S.M., Donohue-Rolfe, A. y Tzipori, S. (2002). "Human Stx2-specific monoclonal antibodies prevent systemic complications of Escherichia coli 0157:H7 infection". Infection and Immunity 70, 612-619.

$\mathrm{N}$

Nadya, S., Delaquis, P., Chen, J., Allen, K., Johnson, R.P., Ziebell, K., Laing, C., Gannon, V., Bach, S. y Topp, E. (2016). "Phenotypic and genotypic characteristics of Shiga toxin-producing Escherichia coli isolated from surface waters and sediments in a Canadian urban-agricultural landscape". Frontiers in Cellular and Infection Microbiology 6, 36.

Nallapareddy, S.R., Qin, X., Weinstock, G.M., Höök, M. y Murray, B.E. (2000). “Enterococcus faecalis adhesin, ace, mediates attachment to extracellular matrix proteins collagen type IV and laminin as well as collagen type I". Infection and Immunity 68, 5218-5224.

Nørrung, B. y Buncic, S. (2008). "Microbial safety of meat in the European Union". Meat Science 78, 14-24.

0

O'brien, A.D., Laveck, G.D., Thompson, M.R. y Formal, S.B. (1982). "Production of Shigella dysenteriae type 1-like cytotoxin by Escherichia coli". The Journal of Infectious Diseases 146, 763-769. 
O'brien, A.D., Newland, J.W., Miller, S.F., Holmes, R.K., Smith, H.W. y Formal, S.B. (1984). "Shigalike toxin-converting phages from Escherichia coli strains that cause hemorrhagic colitis or infantile diarrhea". Science 226, 694-696.

Orihuel, A., Bonacina, J., Vildoza, M.J., Bru, E., Vignolo, G., Saavedra, L. y Fadda, S. (2018). "Biocontrol of Listeria monocytogenes in a meat model using a combination of a bacteriocinogenic strain with curing additives". Food Research International 107, 289-296.

P

Paton, A.W. y Paton, J.C. (1998). "Detection and Characterization of Shiga Toxigenic Escherichia coli by Using Multiplex PCR Assays for stx 1, stx 2, eaeA, Enterohemorrhagic E. coli hlyA, rfb O111, andrfb O157". Journal of Clinical Microbiology 36, 598-602.

Peng, Z., Krey, V., Wei, H., Tan, Q., Vogelmann, R., Ehrmann, M.A. y Vogel, R.F. (2014). “Impact of actin on adhesion and translocation of Enterococcus faecalis". Archives of Microbiology 196, 109-117.

Pingitore, E.V., Todorov, S.D., Sesma, F. y De Melo Franco, B.D.G. (2012). "Application of bacteriocinogenic Enterococcus mundtii CRL35 and Enterococcus faecium ST88Ch in the control of Listeria monocytogenes in fresh Minas cheese". Food Microbiology $32,38-47$.

Prudêncio, C.V., Dos Santos, M.T. y Vanetti, M.C.D. (2015). "Strategies for the use of bacteriocins in Gram-negative bacteria: relevance in food microbiology". Journal of Food Science and Technology 52, 5408-54 17.

$\mathrm{R}$

Ramnath, M., Arous, S., Gravesen, A., Hastings, J.W. y Hechard, Y. (2004). "Expression of mptC of Listeria monocytogenes induces sensitivity to class lla bacteriocins in Lactococcus lactis". Microbiology 150, 2663-2668.

Rangel, J.M., Sparling, P.H., Crowe, C., Griffin, P.M. y Swerdlow, D.L. (2005). “Epidemiology of Escherichia coli O 157:H7 outbreaks, united states, 1982-2002". Emerging Infectious Diseases 11, 603.

Rasooly, R. y Do, P.M. (2010). "Shiga toxin Stx2 is heat-stable and not inactivated by pasteurization". International Journal of Food Microbiology 136, 290-294.

Ratman, S. y March, S. (1986). "Sporadic occurrence of hemorrhagic colitis associated with Escherichia coli in New-foundland". Canadian Medical Association Journal 134, 43-49.

Repetto, H.A. (2005). "Long-term course and mechanisms of progression of renal disease in hemolytic uremic syndrome". Kidney International 68, S102-S106.

Rich, A.R., Jepson, A.N., Luebbe, M.K., Erickson, G.E., Klopfenstein, T.J., Smith, D.R. y Moxley, R.A. (2010). "Vaccination to reduce the prevalence of Escherichia coli O 157:H7 in 
feedlot cattle fed wet distillers grains plus solubles". Nebraska Beef Cattle Reports 580.

Rios-Covián, D., Sánchez, B., Martínez, N., Cuesta, I., Hernández-Barranco, A.M., De Los Reyes-Gavilán, C.G. y Gueimonde, M. (2016). “A proteomic approach towards understanding the cross talk between Bacteroides fragilis and Bifidobacterium longum in coculture". Canadian journal of microbiology 62, 623-628.

Rios-Covian, D., Sánchez, B., Salazar, N., Martínez, N., Redruello, B., Gueimonde, M. y De Los Reyes-Gavilán, C.G. (2015). "Different metabolic features of Bacteroides fragilis growing in the presence of glucose and exopolysaccharides of bifidobacteria". Frontiers in Microbiology 6.

Rivas, L., Dykes, G.A. y Fegan, N. (2006a). "Attachment of Shiga toxigenic Escherichia coli to beef muscle and adipose tissue". Journal of Food Protection 69, 999-1006.

Rivas, M., Miliwebsky, E., Chinen, I., Deza, N. y Leotta, G.A. (2006b). “Epidemiologia del sindrome uremico hemolitico en Argentina. Diagnóstico del agente etiológico, reservorios y vías de transmisión". Medicina 66, 27-32.

Rivero, M., Passucci, J., Rodriguez, E. y Parma, A. (2012). "Seasonal variation of HUS occurrence and VTEC infection in children with acute diarrhoea from Argentina". European Journal of Clinical Microbiology \& infectious diseases 31, 1131-1135.

Rivero, M.A., Passucci, J.A., Rodriguez, E.M. y Parma, A.E. (2010). "Role and clinical course of verotoxigenic Escherichia coli infections in childhood acute diarrhoea in Argentina". Journal of Medical Microbiology 59, 345-352.

Robinson, C.M., Sinclair, J.F., Smith, M.J. y O'brien, A.D. (2006). "Shiga toxin of enterohemorrhagic Escherichia coli type O 157:H7 promotes intestinal colonization". Proceedings of the National Academy of Sciences 103, 9667-9672.

Rojas-Herrera, R.A. y González-Flores, T. (2006). "Detección e identificación de bacterias causantes de enfermedades transmitidas por alimentos mediante la reacción en cadena de la polimerasa". Bioquimia 31, 69-76.

Römer, W., Berland, L., Chambon, V., Gaus, K., Windschiegl, B., Tenza, D., Aly, M.R., Fraisier, V., Florent, J.-C. y Perrais, D. (2007). "Shiga toxin induces tubular membrane invaginations for its uptake into cells". Nature 450, 670.

S

Saavedra, L., Castellano, P., Sesma, F. (2004). "Purificación de bacteriocinas producidas por bacterias ácido lácticas," in Microbiología de Salud Pública. Métodos y protocolos, ed. J.F.T. Spencer Y A.L. Ragout De Spencer. (Humana Press. Totowa, New Jersey, USANew Jersey, USA), 331-336.

Saeedi, P., Yazdanparast, M., Behzadi, E., Salmanian, A.H., Mousavi, S.L., Nazarian, S. y Amani, J. (2017). "A review on strategies for decreasing E. coli O157:H7 risk in animals". Microbial Pathogenesis 103, 186-195. 
Salvucci, E., Saavedra, L. y Sesma, F. (2007). "Short peptides derived from the NH2-terminus of subclass lla bacteriocin enterocin CRL35 show antimicrobial activity". Journal of Antimicrobial Chemotherapy 59, $1102-1108$.

Sambrook, J., Fritsch, E. y Maniatis, T. (1989). "Molecular cloning: a laboratory manual", 3 vols. Cold Spring Harbor Laboratory Press. Cold Spring Harbor, NY.

Schlundt, J., Toyofuku, H., Jansen, J. y Herbst, S. (2004). "Emerging food-borne zoonoses". Revue Scientifique et Technique-Office International des Epizooties 23, 513-534.

Semanjski, M. y Macek, B. (2016). "Shotgun proteomics of bacterial pathogens: advances, challenges and clinical implications". Expert Rev Proteomics 13, 139-156.

Shannon, P., Markiel, A., Ozier, O., Baliga, N.S., Wang, J.T., Ramage, D., Amin, N., Schwikowski, B. y ldeker, T. (2003). "Cytoscape: a software environment for integrated models of biomolecular interaction networks". Genome Research 13, 2498-2504.

Signorini, M., Costa, M., Teitelbaum, D., Restovich, V., Brasesco, H., García, D., Superno, V., Petroli, S., Bruzzone, M. y Arduini, V. (2018). "Evaluation of decontamination efficacy of commonly used antimicrobial interventions for beef carcasses against Shiga toxin-producing Escherichia coli". Meat Science 142, 44-51.

Skandamis, P.N. y Nychas, G.-J.E. (2000). “Development and evaluation of a model predicting the survival of Escherichia coli O157:H7 NCTC 12900 in homemade eggplant salad at various temperatures, $\mathrm{pHs}$, and oregano essential oil concentrations". Applied and Environmental Microbiology 66, 1646-1653.

Smith, L., Mann, J., Harris, K., Miller, M. y Brashears, M. (2005). "Reduction of Escherichia coli O157:H7 and Salmonella in ground beef using lactic acid bacteria and the impact on sensory properties". Journal of Food Protection 68, 1587-1592.

Sofos, J.N. (2008). "Challenges to meat safety in the 21 st century". Meat Science 78, 3-13.

Sparo, M., Confalonieri, A., Urbizu, L., Ceci, M. y Sánchez Bruni, S. (2013). "Bio-preservation of ground beef meat by Enterococcus faecalis CECT7 121". Brazilian Journal of Microbiology 44, 43-49.

Sperandio, V. y Pacheco, A.R. (2012). "Shiga toxin in enterohemorrhagic E. coli: regulation and novel anti-virulence strategies". Frontiers in Cellular and Infection Microbiology 2,81 .

Szklarczyk, D., Franceschini, A., Wyder, S., Forslund, K., Heller, D., Huerta-Cepas, J., Simonovic, M., Roth, A., Santos, A., Tsafou, K.P., Kuhn, M., Bork, P., Jensen, L.J. y Von Mering, C. (2015). "STRING v 10: protein-protein interaction networks, integrated over the tree of life". Nucleic Acids Res 43, D447-452.

T

Tamblyn, K.C. y Conner, D.E. (1997). "Bactericidal Activity of Organic Acids against Salmonella typhimurium Attached to Broiler Chicken Skint". Journal of Food Protection 60, 629-633. 
Tarr, P.I., Gordon, C.A. y Chandler, U.L. (2005). "Shiga-toxin-producing Escherichia coli and haemolytic uraemic syndrome". The lancet 365, 1073-1086.

Thelen, J.J. (2007). "Introduction to proteomics: "A brief historical perspective on contemporary approaches" in Plant Proteomics. Springer, 1-13.

Thomson, D.U., Loneragan, G.H., Thornton, A.B., Lechtenberg, K.F., Emery, D.A., Burkhardt, D.T. y Nagaraja, T.G. (2009). "Use of a siderophore receptor and porin proteins-based vaccine to control the burden of Escherichia coli O157:H7 in feedlot cattle". Foodborne Pathogens and Disease 6, 871-877.

U

Uniprot, C. (2015). “UniProt: a hub for protein information". Nucleic Acids Res 43, D204212.

V

Vignolo, G.M., Ruiz Holgado, A.P.D. y Oliver, G. (1988). “Acid production and proteolytic activity of Lactobacillus strains isolated from dry sausages". Journal of Food Protection 51, 481-484.

Visvalingam, J. y Holley, R.A. (2018). "Evaluation of chlorine dioxide, acidified sodium chlorite and peroxyacetic acid for control of Escherichia coli O157:H7 in beef patties from treated beef trim". Food Research International 103, 295-300.

W

Wachsman, M.B., FaríAs, M.a.E., Takeda, E., Sesma, F., De Ruiz Holgado, A.P., De Torres, R.A. y Coto, C.E. (1999). "Antiviral activity of enterocin CRL35 against herpesviruses". International Journal of Antimicrobial Agents 12, 293-299.

Weeratna, R.D. y Doyle, M.P. (1991). "Detection and production of verotoxin 1 of Escherichia coli O157:H7 in food". Applied and Environmental Microbiology 57, 2951-2955.

Wessels, S., Axelsson, L., Hansen, E.B., De Vuyst, L., Laulund, S., Lähteenmäki, L., Lindgren, S., Mollet, B., Salminen, S. y Von Uright, A. (2004). "The lactic acid bacteria, the food chain, and their regulation". Trends in Food Science \& Technology 15, 498-505.

Woraprayote, W., Malila, Y., Sorapukdee, S., Swetwiwathana, A., Benjakul, S. y Visessanguan, W. (2016). "Bacteriocins from lactic acid bacteria and their applications in meat and meat products". Meat Science 120, 118-132.

Y

Yadav, A.K., Tyagi, A., Kumar, A., Saklani, A.C., Grover, S. y Batish, V.K. (2015). "Adhesion of indigenous Lactobacillus plantarum to gut extracellular matrix and its physicochemical characterization". Archives of Microbiology 197, 155-164. 
Yang, D., Uu, X., Yu, X., He, L., Shah, N.P. y Xu, F. (2017). "Mutual growth-promoting effect between Bifidobacterium bifidum $\mathrm{UBBIO} 3$ and Listeria monocytogenes CMCC 5400 1". Journal of Dairy Science 100, 3448-3462.

Yang, Y., Hu, M., Yu, K., Zeng, X. y Liu, X. (2015). “Mass spectrometry-based proteomic approaches to study pathogenic bacteria-host interactions". Protein $\&$ cell 6, 265274.

Yousef, A.E. y Courtney, P.D. (2003). "Basics of stress adaptation and implications in newgeneration foods". Microbial Stress Adaptation and Food Safety 1, 1-30.

Z

Zhang, J., Ye, K.-P., Zhang, X., Pan, D.-D., Sun, Y.-Y. y Cao, J.-X. (2017). “Antibacterial activity and mechanism of action of black pepper essential oil on meat-borne Escherichia coli". Frontiers in Microbiology 7, 2094.

Zulfakar, S.S., White, J.D., Ross, T. y Tamplin, M.L. (2012). "Bacterial attachment to immobilized extracellular matrix proteins in vitro". International Journal of Food Microbiology 157, $210-217$. 

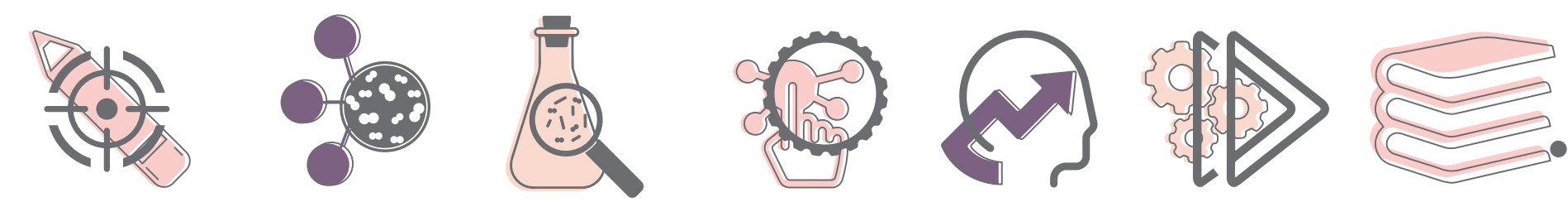

\section{Escherichia coli enterohemorrágico (ECEH)}

es un patógeno alimentario, transmitido principalmente a través de productos cárnicos y

causante del Síndrome Urémico Hemolítico, principal causa de insuficiencia renal aguda en niños en Argentina, siendo a nivel mundial, el país con mayor incidencia de esta patología. Por ello, ECEH constituye una gran preocupación para la sostenibilidad de la industria de la carne y una grave amenaza para la salud pública. En este contexto surge la necesidad de aportar, desde el ámbito científico, soluciones inmediatas para prevenir riesgos futuros.

Los estudios fisiológicos, proteómicos y tecnológicos llevados a cabo en esta tesis sientan las bases para la utilización de un cultivo láctico bioprotector como estrategia biológica para el control de este patógeno, constituyendo un importante aporte a la tecnología de alimentos cárnicos, con impacto positivo en salud pública.
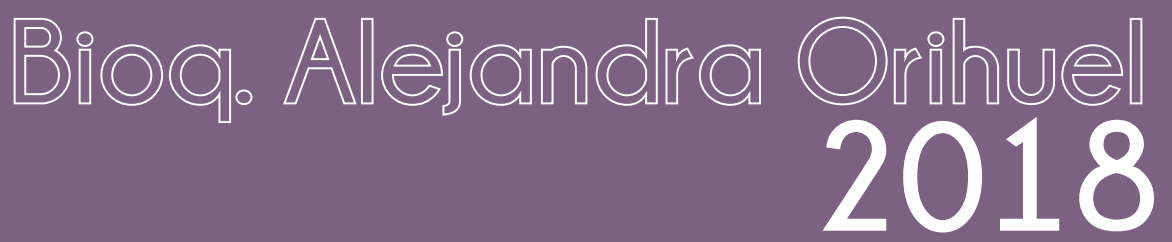